\title{
Cochrane
}

Library

Cochrane Database of Systematic Reviews

\section{Mucolytic agents versus placebo for chronic bronchitis or chronic obstructive pulmonary disease (Review)}

Poole P, Sathananthan K, Fortescue R

Poole P, Sathananthan K, Fortescue R.

Mucolytic agents versus placebo for chronic bronchitis or chronic obstructive pulmonary disease.

Cochrane Database of Systematic Reviews 2019, Issue 5. Art. No.: CD001287.

DOI: 10.1002/14651858.CD001287.pub6.

www.cochranelibrary.com

Mucolytic agents versus placebo for chronic bronchitis or chronic obstructive pulmonary disease (Review) Copyright $\odot 2020$ The Cochrane Collaboration. Published by John Wiley \& Sons, Ltd. 
TABLE OF CONTENTS

ABSTRAC 1

PLAIN LANGUAGE SUMMARY

SUMMARY OF FINDINGS

Figure 1.

Figure 2.

BACKGROUND

OBJECTIVES

METHODS

RESULTS

Figure 3.

Figure 4.

Figure 5.

Figure 6.

Figure 7.

Figure 8.

DISCUSSION

AUTHORS' CONCLUSIONS

ACKNOWLEDGEMENTS

REFERENCES

CHARACTERISTICS OF STUDIES

DATA AND ANALYSES

Analysis 1.1. Comparison 1 Mucolytic versus placebo, Outcome 1 Participants with no exacerbations in study period. ............

Analysis 1.2. Comparison 1 Mucolytic versus placebo, Outcome 2 Participants with no exacerbation by decade, double-blind trials only.

Analysis 1.3. Comparison 1 Mucolytic versus placebo, Outcome 3 Participants with no exacerbations in the study period - winter treatment only.

Analysis 1.4. Comparison 1 Mucolytic versus placebo, Outcome 4 Participants with no exacerbations in study period - by dose or type of mucolytic.

Analysis 1.5. Comparison 1 Mucolytic versus placebo, Outcome 5 Participants with no exacerbations in study period-by FEV . . $_{\text {. }}$

Analysis 1.6. Comparison 1 Mucolytic versus placebo, Outcome 6 Participants with no exacerbations in study period - by study duration.

Analysis 1.7. Comparison 1 Mucolytic versus placebo, Outcome 7 Participants with no exacerbations in study period - by country.

Analysis 1.8. Comparison 1 Mucolytic versus placebo, Outcome 8 Participants with no exacerbations in study period - by history of exacerbation.

Analysis 1.9. Comparison 1 Mucolytic versus placebo, Outcome 9 Participants with no exacerbations in study period - by ICS use.

Analysis 1.10. Comparison 1 Mucolytic versus placebo, Outcome 10 Number of exacerbations per participant per month. ......

Analysis 1.11. Comparison 1 Mucolytic versus placebo, Outcome 11 Days of disability per participant per month. ..................

Analysis 1.12. Comparison 1 Mucolytic versus placebo, Outcome 12 Days on antibiotics per participant per month. .................

Analysis 1.13. Comparison 1 Mucolytic versus placebo, Outcome $13 \mathrm{FEV}_{1}$ at end of study.

Analysis 1.14. Comparison 1 Mucolytic versus placebo, Outcome 14 Percent predicted FEV . $_{\text {. }}$.

Analysis 1.15. Comparison 1 Mucolytic versus placebo, Outcome 15 PEFR at end of study.

Analysis 1.16. Comparison 1 Mucolytic versus placebo, Outcome $16 \mathrm{FVC}$ at end of study.

Analysis 1.17. Comparison 1 Mucolytic versus placebo, Outcome 17 Adverse effects.

Analysis 1.18. Comparison 1 Mucolytic versus placebo, Outcome 18 Hospitalisation during study period.

Analysis 1.19. Comparison 1 Mucolytic versus placebo, Outcome 19 Death during study period.

Analysis 1.20. Comparison 1 Mucolytic versus placebo, Outcome 20 Health-related quality of life (total score St. George's Respiratory Questionnaire).

Analysis 1.21. Comparison 1 Mucolytic versus placebo, Outcome 21 Health-related quality of life (total score COPD Assessment Test).

Analysis 2.1. Comparison 2 Systemic thiol donor versus placebo, Outcome 1 Participants with no exacerbations in the study period. 
Analysis 2.2. Comparison 2 Systemic thiol donor versus placebo, Outcome 2 Number of exacerbations per participant per month.

Analysis 2.3. Comparison 2 Systemic thiol donor versus placebo, Outcome 3 Days of disability per participant per month. ......

Analysis 2.4. Comparison 2 Systemic thiol donor versus placebo, Outcome 4 Adverse effects. ADDITIONAL TABLES

APPENDICES

FEEDBACK

WHAT'S NEW

HISTORY 
[Intervention Review]

\section{Mucolytic agents versus placebo for chronic bronchitis or chronic obstructive pulmonary disease}

Phillippa Poole ${ }^{1}$, Kavin Sathananthan ${ }^{2}$, Rebecca Fortescue ${ }^{3}$

1Department of Medicine, University of Auckland, Auckland, New Zealand. 2Population Health Research Institute, St George's, University of London, London, UK. ${ }^{3}$ Cochrane Airways, Population Health Research Institute, St George's, University of London, London, UK

Contact: Rebecca Fortescue, Cochrane Airways, Population Health Research Institute, St George's, University of London, London, SW17 ORE, UK.rnormans@sgul.ac.uk.

Editorial group: Cochrane Airways Group.

Publication status and date: Edited (no change to conclusions), comment added to review, published in Issue 3, 2020.

Citation: Poole P, Sathananthan K, Fortescue R. Mucolytic agents versus placebo for chronic bronchitis or chronic obstructive pulmonary disease. Cochrane Database of Systematic Reviews 2019, Issue 5. Art. No.: CD001287. DOI: 10.1002/14651858.CD001287.pub6.

Copyright @ 2020 The Cochrane Collaboration. Published by John Wiley \& Sons, Ltd.

\section{A B S T R A C T}

\section{Background}

Individuals with chronic bronchitis or chronic obstructive pulmonary disease (COPD) may suffer recurrent exacerbations with an increase in volume or purulence of sputum, or both. Personal and healthcare costs associated with exacerbations indicate that therapies that reduce the occurrence of exacerbations are likely to be useful. Mucolytics are oral medicines that are believed to increase expectoration of sputum by reducing its viscosity, thus making it easier to cough it up. Improved expectoration of sputum may lead to a reduction in exacerbations of COPD.

\section{Objectives}

\section{Primary objective}

- To determine whether treatment with mucolytics reduces exacerbations and/or days of disability in patients with chronic bronchitis or COPD

\section{Secondary objectives}

- To assess whether mucolytics lead to improvement in lung function or quality of life

- To determine frequency of adverse effects associated with use of mucolytics

\section{Search methods}

We searched the Cochrane Airways Group Specialised Register and reference lists of articles on 12 separate occasions, most recently on 23 April 2019.

\section{Selection criteria}

We included randomised studies that compared oral mucolytic therapy versus placebo for at least two months in adults with chronic bronchitis or COPD. We excluded studies of people with asthma and cystic fibrosis.

\section{Data collection and analysis}

This review analysed summary data only, most derived from published studies. For earlier versions, one review author extracted data, which were rechecked in subsequent updates. In later versions, review authors double-checked extracted data and then entered data into RevMan 5.3 for analysis. 


\section{Main results}

We added four studies for the 2019 update. The review now includes 38 trials, recruiting a total of 10,377 participants. Studies lasted between two months and three years and investigated a range of mucolytics, including $\mathrm{N}$-acetylcysteine, carbocysteine, erdosteine, and ambroxol, given at least once daily. Many studies did not clearly describe allocation concealment, and we had concerns about blinding and high levels of attrition in some studies. The primary outcomes were exacerbations and number of days of disability.

Results of 28 studies including 6723 participants show that receiving mucolytics may be more likely to be exacerbation-free during the study period compared to those given placebo (Peto odds ratio (OR) 1.73, 95\% confidence interval ( $\mathrm{Cl}$ ) 1.56 to 1.91 ; moderate-certainty evidence). However, more recent studies show less benefit of treatment than was reported in earlier studies in this review. The overall number needed to treat with mucolytics for an average of nine months to keep an additional participant free from exacerbations was eight (NNTB 8, 95\% Cl 7 to 10). High heterogeneity was noted for this outcome $\left(I^{2}=62 \%\right)$, so results need to be interpreted with caution. The type or dose of mucolytic did not seem to alter the effect size, nor did the severity of COPD, including exacerbation history. Longer studies showed smaller effects of mucolytics than were reported in shorter studies.

Mucolytic use was associated with a reduction of 0.43 days of disability per participant per month compared with use of placebo $(95 \% \mathrm{Cl}$ -0.56 to -0.30 ; studies $=9 ; 1^{2}=61 \%$; moderate-certainty evidence). With mucolytics, the number of people with one or more hospitalisations was reduced, but study results were not consistent (Peto OR $0.68,95 \% \mathrm{Cl} 0.52$ to 0.89 ; participants $=1788$; studies $=4 ; \mathrm{I}^{2}=58 \%$; moderatecertainty evidence). Investigators reported improved quality of life with mucolytics (mean difference (MD) $-1.37,95 \% \mathrm{Cl}-2.85$ to 0.11 ; participants $=2721$; studies $=7 ; I^{2}=64 \%$; moderate-certainty evidence). However, the mean difference did not reach the minimal clinically important difference of -4 units, and the confidence interval includes no difference. Mucolytic treatment was associated with a possible reduction in adverse events (OR $0.84,95 \% \mathrm{Cl} 0.74$ to 0.94 ; participants $=7264$; studies $=24 ; \mathrm{I}^{2}=46 \%$; moderate-certainty evidence), but the pooled effect includes no difference if a random-effects model is used. Several studies that could not be included in the meta-analysis reported high numbers of adverse events, up to a mean of five events per person during follow-up. There was no clear difference between mucolytics and placebo for mortality, but the confidence interval is too wide to confirm that treatment has no effect on mortality (Peto OR $0.98,95 \% \mathrm{Cl} 0.51$ to 1.87 ; participants $=3527$; studies $=11 ;\left.\right|^{2}=0 \%$; moderate-certainty evidence).

\section{Authors' conclusions}

In participants with chronic bronchitis or COPD, we are moderately confident that treatment with mucolytics leads to a small reduction in the likelihood of having an acute exacerbation, in days of disability per month and possibly hospitalisations, but is not associated with an increase in adverse events. There appears to be limited impact on lung function or health-related quality of life. Results are too imprecise to be certain whether or not there is an effect on mortality. Our confidence in the results is reduced by high levels of heterogeneity in many of the outcomes and the fact that effects on exacerbations shown in early trials were larger than those reported by more recent studies. This may be a result of greater risk of selection or publication bias in earlier trials, thus benefits of treatment may not be as great as was suggested by previous evidence.

\section{PLAIN LANGUAGE SUMMARY}

\section{Mucolytic agents for chronic bronchitis or chronic obstructive pulmonary disease}

\section{Background to the question}

Chronic obstructive pulmonary disease (COPD) and chronic bronchitis are long-term breathing conditions. They cause symptoms such as shortness of breath, cough, and excess sputum. People with COPD and chronic bronchitis may have flare-ups (exacerbations) when their symptoms become worse.

Mucolytics are medicines taken orally that may loosen sputum, making it easier to cough it up. Mucolytics may have other beneficial effects on lung infection and inflammation and may reduce the number of flare-ups that people with COPD and chronic bronchitis have. Mucolytics can also be inhaled, but we did not look at inhaled mucolytics in this review.

\section{Study characteristics}

We looked for studies lasting at least two months, in which it was decided at random whether a person received a mucolytic drug or a placebo. We did not include studies involving children or people with other breathing conditions such as asthma and cystic fibrosis.

We found 38 studies to include in our review. These studies included a total of 10,377 adults with COPD or chronic bronchitis. The studies used a variety of mucolytic drugs, including $\mathrm{N}$-acetylcysteine, carbocysteine, and erdosteine and lasted from two months to three years. Mucolytics were taken by mouth between one and three times per day. These studies measured several different outcomes to find out if the drug was useful, including flare-ups, hospital admissions, quality of life, lung function, and side effects.

\section{Key results}

We found that people taking mucolytic drugs were less likely to experience a flare-up compared to those taking placebo. Approximately eight people would need to take the drug for nine months for one extra person to avoid having a flare-up. This result was based on 28 
studies involving 6723 people. However, the studies carried out a longer time ago (1970s to 1990s) show greater benefit than those carried out more recently. Shorter studies also seemed to show more benefit than longer studies. This could be because the newer trials were larger and may be showing that mucolytics are less beneficial than the earlier studies showed. Or it could be that only studies that showed mucolytics as beneficial were published before the 2000s, when there was a push to report all trial results regardless of whether or not they showed benefit.

People taking mucolytics had fewer days of disability (i.e. days when they could not do their normal activities) every month, but this was quite a small difference - less than half a day per person per month. They were also approximately one-third less likely to be admitted to hospital, although this result is based on only five studies that provided this information.

Study results suggest that mucolytics do not have an important impact on quality of life or lung function. People taking mucolytics did not experience more unwanted side effects than those taking placebo. But we could not be sure about their impact on death during the study period because only 37 deaths occurred amongst the 3527 participants in studies where deaths were measured and reported.

\section{Quality of the evidence}

We are moderately confident about the results we have presented. Our confidence is reduced by the results from individual studies looking quite different from one another and the mix of older and newer studies that we found. Also, in some cases there were not enough data to be sure whether mucolytics were better or worse than, or the same as, placebo.

\section{Conclusions}

Mucolytics appear to be useful for reducing flare-ups, days of disability, and hospital admissions in people with COPD or chronic bronchitis, and they do not appear to cause more side effects. However, they do not appear to have much impact on quality of life or lung function, and we could not be sure about their impact on death.

This plain language summary is current to April 2019. 


\section{SUMMARY OF FINDINGS}

\section{Summary of findings for the main comparison. Mucolytic compared to placebo for chronic bronchitis or chronic obstructive pulmonary disease}

Mucolytic compared to placebo for chronic bronchitis or chronic obstructive pulmonary disease

Patient or population: chronic bronchitis or COPD

Setting: community

Intervention: mucolytic

Comparison: placebo

\begin{tabular}{|c|c|c|c|c|c|c|}
\hline \multirow[t]{2}{*}{ Outcomes* } & \multicolumn{2}{|c|}{ Anticipated absolute effects $\dagger(95 \% \mathrm{Cl})$} & \multirow{2}{*}{$\begin{array}{l}\text { Relative effect } \\
(95 \% \mathrm{Cl})\end{array}$} & \multirow{2}{*}{$\begin{array}{l}\text { No. of partici- } \\
\text { pants } \\
\text { (studies) }\end{array}$} & \multirow{2}{*}{$\begin{array}{l}\text { Certainty of } \\
\text { the evidence } \\
\text { (GRADE) }\end{array}$} & \multirow[t]{2}{*}{ Comments } \\
\hline & $\begin{array}{l}\text { Risk with place- } \\
\text { bo }\end{array}$ & Risk with mucolytic & & & & \\
\hline $\begin{array}{l}\text { Participants with no exacerbations in } \\
\text { study period } \\
\text { Follow-up: } 8.8 \text { months }\end{array}$ & 386 per 1000 & $\begin{array}{l}521 \text { per } 1000 \\
(495 \text { to } 545)\end{array}$ & $\begin{array}{l}\text { Peto OR } 1.73 \\
\text { (1.56 to } 1.91)\end{array}$ & $\begin{array}{l}6723 \\
\text { (28 RCTs) }\end{array}$ & $\begin{array}{l}\oplus \oplus \oplus \ominus \\
\text { Moderate } a\end{array}$ & $\begin{array}{l}\text { Generally larger ef- } \\
\text { fects in earlier stud- } \\
\text { ies of mucolytics in } \\
\text { chronic bronchitis } \\
\text { and smaller effects in } \\
\text { more recent studies } \\
\text { in COPD }\end{array}$ \\
\hline $\begin{array}{l}\text { Days of disability per participant per } \\
\text { month } \\
\text { Follow-up: } 8.3 \text { months }\end{array}$ & $\begin{array}{l}\text { Mean days of dis- } \\
\text { ability per partic- } \\
\text { ipant per month } \\
\text { was } 1.57 \text { days }\end{array}$ & $\begin{array}{l}\text { MD } 0.43 \text { days lower } \\
(0.56 \text { lower to } 0.30 \\
\text { lower) }\end{array}$ & - & $\begin{array}{l}2259 \\
\text { (9 RCTs) }\end{array}$ & $\begin{array}{l}\oplus \oplus \oplus \ominus \\
\text { Moderate } e^{a, b}\end{array}$ & \\
\hline $\begin{array}{l}\text { Health-related quality of life (total } \\
\text { score SGRQ) } \\
\text { Scale from } 1 \text { to } 100 \text {; lower scores indicate } \\
\text { better quality of life } \\
\text { Follow-up: } 14.1 \text { months }\end{array}$ & $\begin{array}{l}\text { Mean SGRQ total } \\
\text { score was } 39.02 \\
\text { points }\end{array}$ & $\begin{array}{l}\text { MD } 1.37 \text { lower } \\
\text { ( } 2.85 \text { lower to } 0.11 \\
\text { higher) }\end{array}$ & - & $\begin{array}{l}2721 \\
\text { (7 RCTs) }\end{array}$ & $\begin{array}{l}\oplus \oplus \oplus \ominus \\
\text { Moderate } \\
a, c\end{array}$ & $\begin{array}{l}\text { MCID for SGRQ is } 4 \\
\text { points }\end{array}$ \\
\hline $\begin{array}{l}\text { Hospitalisation during study period } \\
\text { Follow-up: } 16.6 \text { months }\end{array}$ & 188 per 1000 & $\begin{array}{l}136 \text { per } 1000 \\
(107 \text { to } 171)\end{array}$ & $\begin{array}{l}\text { Peto OR } 0.68 \\
\text { (0.52 to } 0.89 \text { ) }\end{array}$ & $\begin{array}{l}1833 \\
\text { (5 RCTs) }\end{array}$ & $\begin{array}{l}\oplus \oplus \oplus \ominus \\
\text { Moderate } a\end{array}$ & \\
\hline $\begin{array}{l}\text { FEV }_{1} \text { at end of study } \\
\text { Follow-up: } 14.5 \text { months }\end{array}$ & $\begin{array}{l}\text { Mean } \mathrm{FEV}_{1} \text { at end } \\
\text { of study was } 1.50 \\
\mathrm{~L}\end{array}$ & $\begin{array}{l}\text { MD } 0.04 \text { L higher } \\
\text { (0.01 higher to } 0.07 \\
\text { higher) }\end{array}$ & - & $\begin{array}{l}3473 \\
\text { (14 RCTs) }\end{array}$ & $\begin{array}{l}\oplus \oplus \oplus \odot \\
\text { Moderate } a, b\end{array}$ & $\begin{array}{l}\text { MCID for } \mathrm{FEV}_{1} \text { in } \\
\text { COPD is approxi- } \\
\text { mately } 0.1 \mathrm{~L} \text { (Jones } \\
\text { 2013) }\end{array}$ \\
\hline
\end{tabular}




\begin{tabular}{|c|c|c|c|c|c|c|c|}
\hline 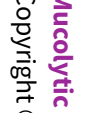 & $\begin{array}{l}\text { Adverse effects } \\
\text { Follow-up: } 8.2 \text { months }\end{array}$ & 235 per 1000 & $\begin{array}{l}205 \text { per } 1000 \\
(185 \text { to } 224)\end{array}$ & $\begin{array}{l}\text { Peto OR } 0.84 \\
\text { (0.74 to } 0.94)\end{array}$ & $\begin{array}{l}7264 \\
\text { (24 RCTs) }\end{array}$ & $\begin{array}{l}\oplus \oplus \oplus \ominus \\
\text { Moderate }^{a}\end{array}$ & \\
\hline 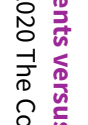 & $\begin{array}{l}\text { Death during study period } \\
\text { Follow-up: } 13.3 \text { months }\end{array}$ & 11 per 1000 & $\begin{array}{l}10 \text { per } 1000 \\
(5 \text { to } 20)\end{array}$ & $\begin{array}{l}\text { Peto OR } 0.98 \\
\text { (0.51 to } 1.87 \text { ) }\end{array}$ & $\begin{array}{l}3527 \\
\text { (11 RCTs) }\end{array}$ & $\begin{array}{l}\oplus \oplus \oplus \ominus \\
\text { Moderate }^{d}\end{array}$ & $\begin{array}{l}18 \text { deaths on mu- } \\
\text { colytics and } 19 \text { on } \\
\text { placebo }\end{array}$ \\
\hline
\end{tabular}

*Follow-up was calculated as a weighted mean duration.

†The risk in the intervention group (and its 95\% confidence interval) is based on the assumed risk in the comparison group and the relative effect of the intervention (and its $95 \% \mathrm{Cl}$ ).

$\mathrm{Cl}$ : confidence interval; COPD: chronic obstructive pulmonary disease; $\mathrm{FEV}_{1}$ : forced expiratory volume in one second; MCID: minimally clinically important difference; MD: mean difference; OR: odds ratio; RCT: randomised controlled trial; RR: risk ratio; SGRQ: St. George's Respiartory Questionaire; WMD: weighted mean duration.

\section{GRADE Working Group grades of evidence.}

High certainty: we are very confident that the true effect lies close to that of the estimate of the effect.

Moderate certainty: we are moderately confident in the effect estimate: the true effect is likely to be close to the estimate of the effect, but there is a possibility that it is substantially different.

Low certainty: our confidence in the effect estimate is limited: the true effect may be substantially different from the estimate of the effect.

Very low certainty: we have very little confidence in the effect estimate: the true effect is likely to be substantially different from the estimate of effect.

a Statistical and clinical heterogeneity identified. Downgraded once for inconsistency.

bFunnel plots suggest small negative trials under-represented (Figure 1; Figure 2). However, removing the positive small trials from the analysis had little impact on the pooled estimate. No downgrade.

${ }^{c}$ Confidence interval includes possibility of no difference between groups, but both ends of confidence interval lie within MCID. No downgrade for imprecision

${ }^{d}$ Confidence interval includes possibility of both an important increase or reduction in deaths. Downgraded once for imprecision. 


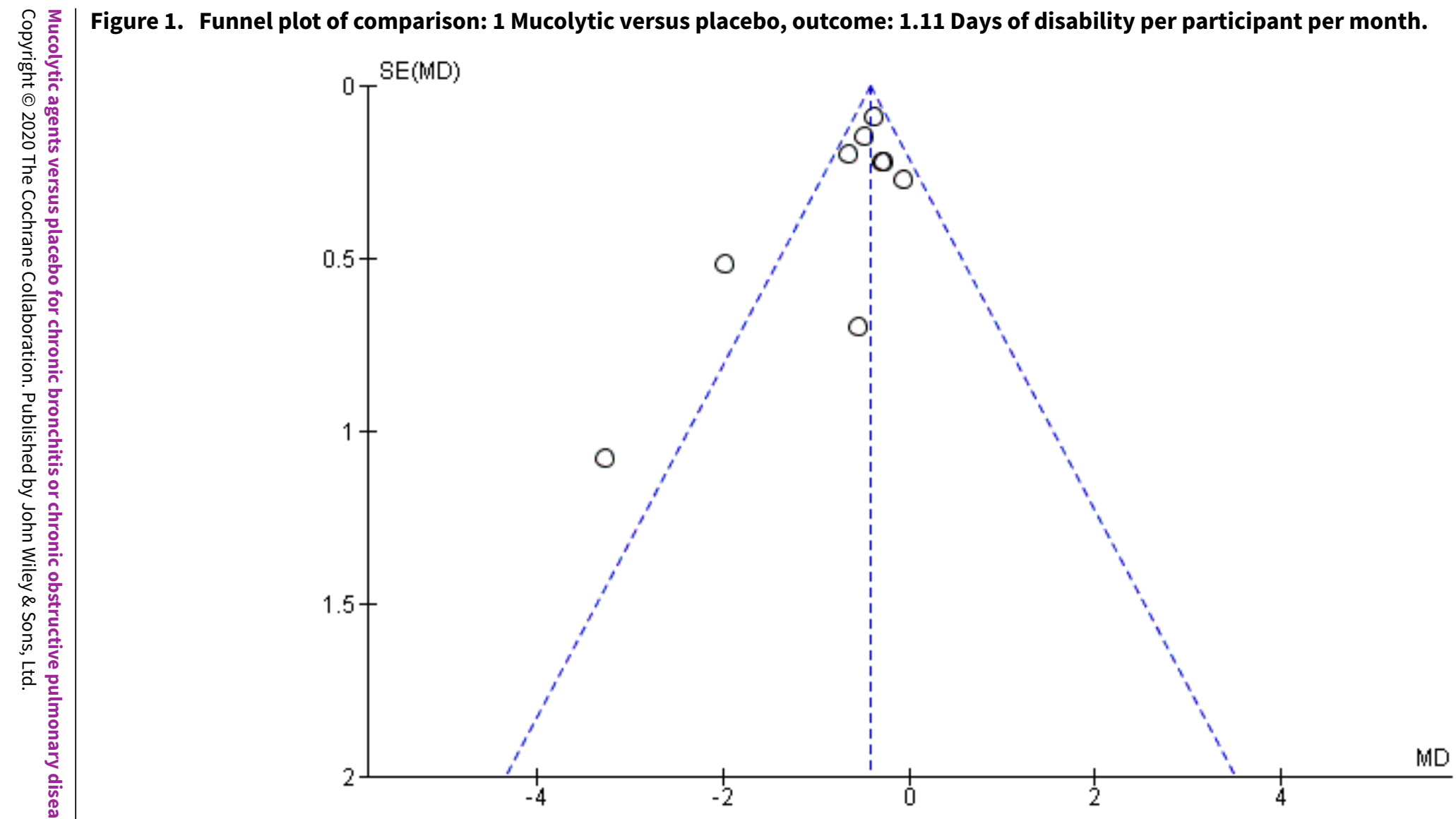




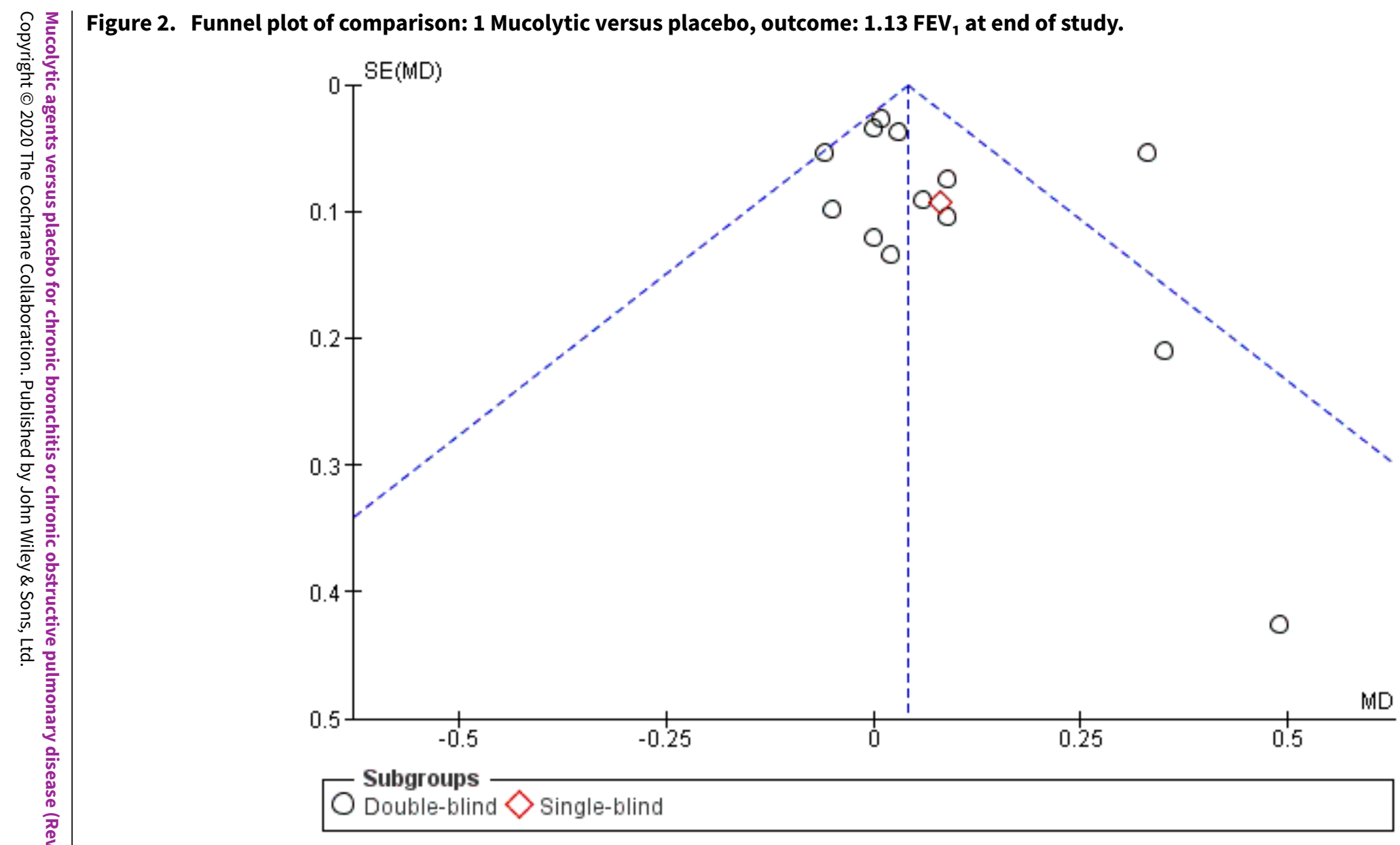




\section{B A C K G R O U N D}

\section{Description of the condition}

Chronic obstructive pulmonary disease (COPD) is a long-term progressive condition primarily affecting the lungs, but with a wide range of extrapulmonary manifestations. Symptoms typically include shortness of breath (dyspnoea), impaired exercise tolerance, wheezing, cough, and sputum production. In more severe cases, COPD may progress to cor pulmonale, respiratory failure, and death (Qaseem 2011). It is estimated that COPD is the fourth most common single cause of death worldwide (WHO 2017). Few interventions have been demonstrated to convincingly reduce mortality, with the exception of smoking cessation, longterm oxygen therapy in hypoxaemic patients and lung volume reduction surgery in selected patients (GOLD 2019; van Agteren 2016).

A diagnosis of COPD is usually made when a person who has symptoms of COPD is found to have airflow obstruction (postbronchodilator forced expiratory volume in one second $\left(\mathrm{FEV}_{1}\right)$ / forced vital capacity $(\mathrm{FVC})<0.70$ ) in the absence of an alternative explanation for the symptoms (e.g. left ventricular failure) or the airflow obstruction (e.g. asthma) (Qaseem 2011). Many people with chronic bronchitis also have COPD. Smoking is the main risk factor for COPD; up to 50\% of smokers will develop COPD, and most will have some breathing impairment (GOLD 2019; Rennard 2006). Chronic bronchitis and COPD are preventable and treatable diseases that are associated with an enhanced chronic inflammatory response to noxious particles or gases in the airways and the lung (GOLD 2019). Exacerbations and comorbidities contribute to overall severity in individual patients.

Exacerbations occur with increasing frequency as the disease becomes more severe. They are characterised by increased breathlessness or greater volume or purulence of sputum, or both. Exacerbations accelerate decline in lung function and are associated with worse quality of life and higher mortality. They are the largest contributor to healthcare costs in COPD (Criner 2015). Thus, treatments that reduce the frequency and duration of acute exacerbations will provide benefit for both individual patients and healthcare systems.

\section{Description of the intervention}

Mucolytics are oral medicines, given at least once daily, that are believed to increase expectoration of sputum by reducing its viscosity, thus making it easier to cough it up. There are several different types of mucolytic, including carbocysteine, acetylcysteine, erdosteine, and ambroxol (Yang 2018). They are given in combination with, rather than instead of, other COPD therapies, such as inhaled long-acting beta ${ }_{2}$-agonists (LABAs) and long-acting muscarinic antagonists (LAMAs).

Mucolytics are included as a treatment option for patients experiencing frequent exacerbations in several national and international management guidelines. International Global Initiative for Chronic Obstructive Lung Disease (GOLD) guidelines state that mucolytics may reduce exacerbations and modestly improve health status, but there is currently a lack of evidence to precisely target the population most likely to benefit (GOLD 2019). COPD-X guidelines, produced in Australia and New Zealand, give a stronger recommendation, stating "there is evidence to support the use of high dose oral $\mathrm{N}$-acetylcysteine in the reduction of COPD exacerbations and improvements in lung function" and "high dose ( $\geq 1200 \mathrm{mg} /$ day) $\mathrm{N}$-acetylcysteine should be considered as an effective therapy for reducing exacerbations" (Yang 2018). UK National Institute for Health and Care Excellence (NICE) guidelines currently suggest that mucolytics should be considered for patients with chronic cough productive of sputum and continued if there is symptomatic improvement. However, the guidelines state they should not be routinely prescribed to prevent exacerbations (NICE 2018). Joint American Thoracic Society/European Respiratory Society (ATS/ERS) guidelines for prevention of exacerbations make the following recommendation: "for patients who have COPD with moderate or severe airflow obstruction and exacerbations despite optimal inhaled therapy, we suggest treatment with an oral mucolytic agent to prevent future exacerbations" (Wedzicha 2017). However, this is qualified as being a conditional recommendation, based on low quality of evidence.

\section{How the intervention might work}

Mucus clearance is one of the most important tools the lung has to protect itself from pathogens (Rubin 2014). Mucus is a gellike material complete with glycoproteins called mucins, serum proteins, and water. In contrast, sputum refers to expectorated mucus with the addition of inflammatory cells and DNA. Mucus is removed from the lungs and airways via cilia hairs and airflow; however sputum is removed primarily by coughing (Rubin 2014).

Mucolytics work by changing the physical properties of the secretions themselves. They can work by degrading the mucin polymers, fibrin, or DNA in airway secretions, which makes them less viscous. This makes it easier for the body to clear them and reduces the risk of bacterial contamination. Classic mucolytics such as $\mathrm{N}$-acetylcysteine (NAC) exert their effects by depolymerising the mucin glycoproteins via a hydrolysis reaction (Rubin 2007). One study found that NAC may improve pulmonary function, but there was uncertainty as to whether or not this was in fact mediated by its antioxidant ability (Hansen 1994). Given that oxidative stress is thought to be an amplifying mechanism in COPD (Rahman 2005), this property of $\mathrm{N}$-acetylcysteine may be useful in chronic airways disease.

Lubricants and surfactant stimulators such as ambroxol can make the sputum less adhesive, making it easier for the cilia to clear and more likely that a cough will be able to transport it throughout the pharynx (Rubin 2007). In a chronic inflammatory process such as COPD, production of phospholipase A2 can cause destruction of the surfactant phospholipids, making the sputum incredibly adherent to the cilia and further causing airway obstruction (Rubin 2007). One study found that aerosolised surfactant was able to increase FEV $1 \%$ predicted and FVC by up to $10 \%$ by reducing adherence of mucus in the airways (Anzueto 1997).

\section{Why it is important to do this review}

As illustrated by varied recommendations from guidelines, there is lack of international consensus on the place of mucolytics in the treatment of COPD. As theoretical reasons have been proposed to explain why mucolytics may work in both chronic bronchitis and COPD, and because treatments that reduce exacerbations are needed to reduce morbidity and costs, this review update will seek to determine the true effect of this class of medicines. 


\section{O B J E C T I VES}

\section{Primary objective}

- To determine whether treatment with mucolytics reduces exacerbations and/or days of disability in patients with chronic bronchitis or COPD

\section{Secondary objectives}

- To assess whether mucolytics lead to improvement in lung function or quality of life

- To determine the frequency of adverse effects associated with use of mucolytics

\section{METHODS}

\section{Criteria for considering studies for this review \\ Types of studies}

We included randomised, placebo-controlled trials.

\section{Types of participants}

We included studies of adults (over 20 years of age) with chronic bronchitis as defined by the British Medical Research Council (cough and sputum on most days during at least three consecutive months for longer than two successive years) or COPD as defined by the criteria of the American Thoracic Society, the Global Initiative for Chronic Obstructive Lung Disease (GOLD), the European Respiratory Society, or the World Health Organization (WHO). We excluded studies on patients with asthma or cystic fibrosis.

\section{Types of interventions}

Participants must have received regular treatment with oral mucolytics or placebo for at least two months. Oral mucolytics included the following compounds: $\mathrm{N}$ acetylcysteine (NAC), S-carboxymethylcysteine, bromhexine, ambroxol, erdosteine, sobrerol, cithiolone, letosteine, iodinated glycerol, $\mathrm{N}$-isobutyrylcysteine, myrtol, and cineole.

We excluded studies of inhaled mucolytics and combinations of mucolytics with antibiotics and mucolytics with bronchodilators, as well as studies of deoxyribonuclease or proteases such as trypsin.

\section{Types of outcome measures}

\section{Primary outcomes}

- Exacerbations, as measured by the number of participants with no exacerbations during the study period, as well as the total number of acute exacerbations per participant ${ }^{\star}$ and time to first exacerbation. Exacerbation was defined as an increase in cough and by volume and/or purulence of sputum

- Number of days of disability variously defined as days in bed, days off work, or days on which the participant was unable to undertake normal activities. We also assessed days on antibiotics

* For the 2019 update, we removed exacerbations per patient per month analyses as these are not considered to be as statistically robust as the dichotomous exacerbation outcome, largely due to likely skew in this measure. Instead we present these data in tables.

\section{Secondary outcomes}

- Measures of lung function, including forced expiratory volume in one second $\left(\mathrm{FEV}_{1}\right)$, forced vital capacity (FVC), and peak expiratory flow rate (PEFR)

- Adverse effects of treatment

- Hospitalisation and mortality

- Quality of life as measured by a tool validated in patients with COPD

We had intended to use symptom scores as a secondary outcome measure, but it became clear that symptoms were not reported in a consistent fashion, and it was not possible to standardise symptom scores.

Adverse events were not usually reported in detail and generally were mild and self-limiting, so we have entered only the total number of adverse events.

\section{Search methods for identification of studies}

\section{Electronic searches}

Search methods and search history for previous versions of this review are detailed in Appendix 1. The previously published version included searches up to July 2014. The search period for this update is July 2014 through April 2019.

We identified studies from the Cochrane Airways Group Trials Register (CAGR), which is maintained by the Information Specialist for the Group. The Cochrane Airways Trials Register contains studies identified from several sources.

- Monthly searches of the Cochrane Central Register of Controlled Trials (CENTRAL), through the Cochrane Register of Studies (CRS).

- Weekly searches of MEDLINE Ovid.

- Weekly searches of Embase Ovid.

- Monthly searches of PsycINFO Ovid.

- Monthly searches of Cumulative Index to Nursing and Allied Health Literature (CINAHL) EBSCO.

- Handsearches of the proceedings of major respiratory conferences.

Studies contained in the Trials Register are identified through search strategies based on the scope of Cochrane Airways. Details of these strategies, as well as a list of handsearched conference proceedings, are provided in Appendix 2. We searched for relevant trials in the Register using the search strategy presented in Appendix 3. We did not apply restrictions on language or type of publication.

\section{Searching other resources}

We checked the references of all papers and reviews for which we obtained the full text to identify other relevant articles. We asked other researchers in the field to provide additional references, and we remained open to unsolicited suggestions regarding potentially eligible studies. For the 2014 and 2019 updates, we searched these online clinical trials registers: ClinicalTrials.gov (www.ClinicalTrials.gov) and the WHO trials portal (www.who.int/ ictrp/en/). 


\section{Data collection and analysis}

\section{Selection of studies}

At least one review author (Peter Black and PP for original review; PP and Jimmy Chong for the 2001, 2006, and 2012 updates; and PP and RF for the 2019 update) assessed all abstracts obtained from the search of the CAGR. We obtained the full text for those that appeared to fit the criteria for inclusion (or if this was not clear from the abstract). Two review authors independently selected trials for inclusion in the original review and updates and resolved disagreements over inclusion by discussion. Six translators (two of whom were medically trained) assessed papers published in languages other than English. For the 2012 and 2014 updates, the review lead author (PP) was assisted by another Cochrane review author (Jimmy Chong) in extracting data. For the 2019 update, RF and KS extracted and entered data, with input from PP.

\section{Data extraction and management}

We extracted data onto worksheets before entering them into the Review Manager software (RevMan 5.3). We double-checked all entries against the original paper. In the 1999 update, we rechecked all data from earlier studies. In the 2019 update, we rechecked lung function data from earlier studies to separate the analyses into $\mathrm{FEV}_{1}$, percent predicted $\mathrm{FEV}_{1}, \mathrm{PEFR}$, and FVC, rather than a combined standardised mean difference analysis.

\section{Assessment of risk of bias in included studies}

We used the following to assess sources of bias in selection, allocation, performance, detection, attrition, or reporting (Higgins 2011).

- Low risk of bias.

- Unclear risk of bias: if insufficient information was available.

- High risk of bias.

When assessing attrition bias, we used an approximate cut-off of $20 \%$ dropout for high risk, although we also took into account the type of analysis performed (e.g. intention-to-treat), the balance between trial arms, and the reasons given for dropout.

\section{Measures of treatment effect}

We analysed continuous data using mean differences (MDs). We used Peto odds ratios (ORs) for dichotomous data and reported results with $95 \%$ confidence intervals $(\mathrm{Cls})$.

\section{Unit of analysis issues}

We calculated exacerbation rates and days of disability by dividing the number of events by the number of participants and the number of months of the study (i.e. per participant per month). We scaled standard deviations for monthly rates in the same way. For the 2019 update, we archived the exacerbation rates analyses.

\section{Dealing with missing data}

If data were insufficient, we requested further information by writing to the study author or to the pharmaceutical company sponsoring the study.

\section{Assessment of heterogeneity}

We used the $\mathrm{I}^{2}$ statistic to measure heterogeneity among the trials in each analysis. We reported cases of substantial heterogeneity and explored possible causes by performing prespecified subgroup analysis. As per the Cochrane Handbook for Systematic Reviews of Interventions (Higgins 2011), we considered the following ranges for assessing heterogeneity.

- $0 \%$ to $40 \%$ : might not be important.

- $30 \%$ to $60 \%$ : may represent moderate heterogeneity.

- $50 \%$ to $90 \%$ : may represent substantial heterogeneity.

- $75 \%$ to $100 \%$ : may show considerable heterogeneity.

\section{Assessment of reporting biases}

When we were able to pool more than 10 trials, we created and examined a funnel plot to explore possible small-study and publication biases.

\section{Data synthesis}

We used summary statistics rather than individual patient data. We used a fixed-effect model.

For the outcome of having 'no exacerbation in the study period', we calculated a number needed to treat for an additional beneficial outcome (NNTB) based on the pooled Peto odds ratio (Cates 2002), with baseline risk taken from the pooled control group event rate (total number of events divided by overall number of participants in the placebo group multiplied by 100).

\section{Subgroup analysis and investigation of heterogeneity}

From the outset, we planned a priori subgroup analyses based on type of mucolytic, dose, duration, country of study, disease severity, and whether or not participants were included, as they had a history of exacerbation.

Following publication of the BRONCUS study (Decramer 2005), which suggested a differential effect of mucolytics depending on concomitant treatment, we included an analysis on whether concomitant inhaled corticosteroids were permitted.

From 2012 onwards, we carried out a post hoc investigation of time trends in data for participants with one or more exacerbations by comparing results of trials published since 2000 versus those published earlier.

\section{Sensitivity analysis}

For 2012 onwards, we explored heterogeneity in results on exacerbations, and we conducted a sensitivity analysis using data from trials assessed as having low risk of selection bias (on the basis of allocation concealment). For the 2019 update, we conducted a sensitivity analysis removing studies judged to be at high risk of attrition bias.

\section{RES U L T S}

\section{Description of studies}

\section{Results of the search}

For details of the search history, see Appendix 1, and for the PRISMA (Preferred Reporting Items for Systematic Reviews and Meta-Analyses) study flow diagram for this update, see Figure 3. 
Figure 3. Study flow diagram: review update.

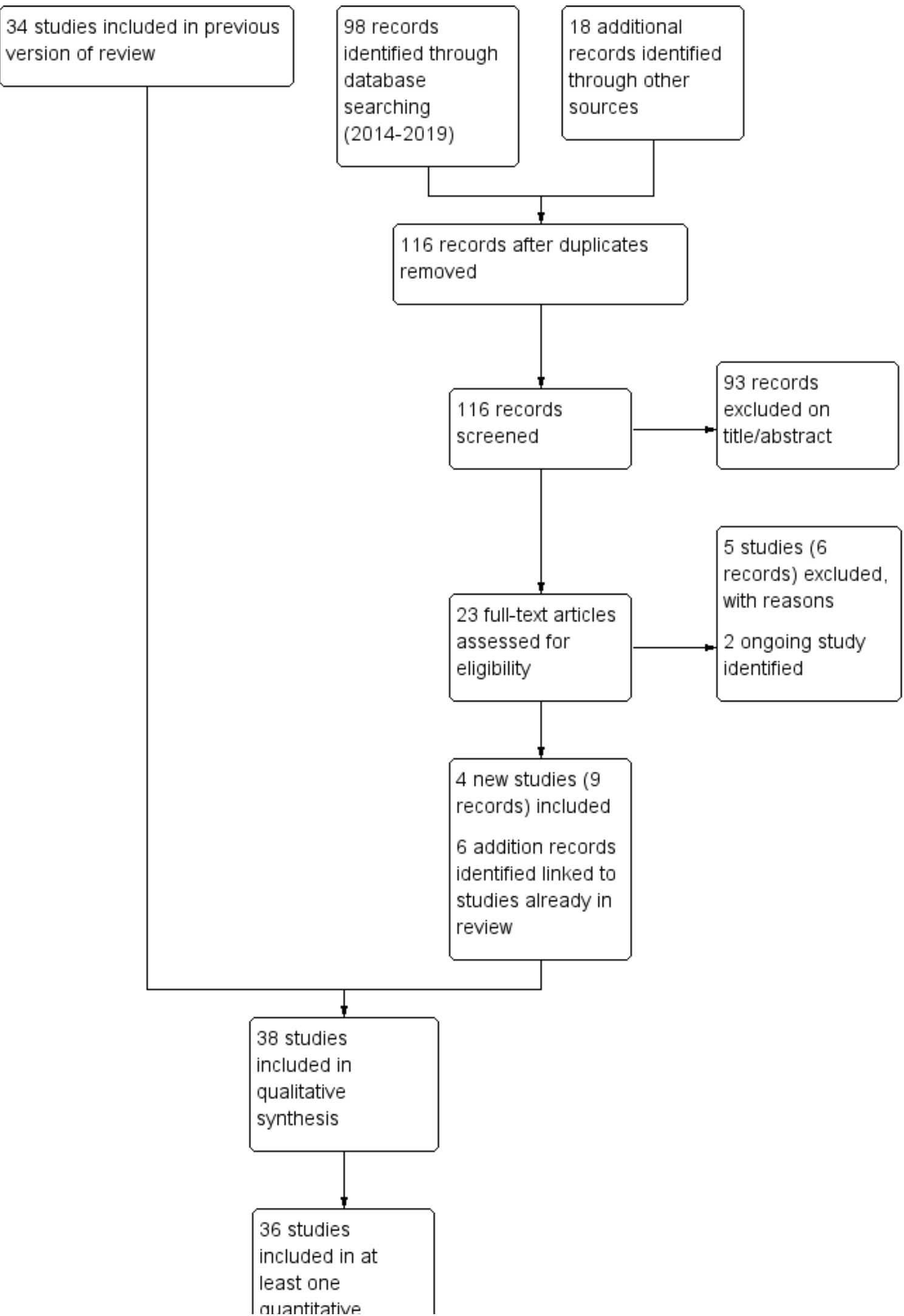


Figure 3. (Continued)

\author{
least one \\ quantitative \\ synthesis \\ (meta-analysis)
}

After de-duplication, the database search run on 23 April 2019 yielded 98 references, and searches of clinical trial registries identified a further 18 records. We excluded 93 on the basis of title and abstract and reviewed 23 full texts for possible inclusion. We excluded a further six records (five unique studies) at this stage and identified two ongoing studies that meet the inclusion criteria for this review (Characteristics of ongoing studies). The remaining 15 records were eligible for inclusion. We added nine records, linked to four new unique studies, to the review (Dal Negro 2017; Fukuchi 2016; Johnson 2016; Xu 2014). We identified a further six records, which were additional references to studies already included in the review. We wrote to authors of all four newly included studies to request further information; we received a response from the authors of Dal Negro 2017, Fukuchi 2016, and Johnson 2016, and we are grateful to Professor Dal Negro, Professor Inoue, and Dr Niewoehner for the additional data/details they provided.

The 2014 search yielded 29 abstracts, as well as four new eligible studies - all of NAC versus placebo. Four abstracts related to the eligible study of Zheng 2014, four to Tse 2013, three to De Backer 2013, and one to Roy 2014. We found a total of 17 reports of ineligible studies, including Moretti 2011, which in 2012 was awaiting classification. We found a further report of the Roy study while searching for study authors' contact details. Searches of online clinical trials databases yielded no further studies.

In the initial review in 1997, we wrote to the authors of 10 studies (Allegra 1996; Babolini 1980; Boman 1983; Castiglioni 1986; Christensen 1971; Grillage 1985; Jackson 1984; Nowak 1999; Parr 1987; Petty 1990) to request more information. We received further data for two studies (Allegra 1996; Nowak 1999). Dr Petty responded to our letter but could not supply data because they were held by a pharmaceutical company (the company has not replied to two letters). Dr Boman wrote to say that he was unable to supply us with additional data. This was also the case for Novartis Pharmaceuticals (UK), which responded on behalf of two study authors (Jackson 1984; Parr 1987), and Parke Davis Research Laboratories (Grillage 1985). We received no reply to our request for additional data related to the remaining three studies (Babolini 1980; Castiglioni 1986; Christensen 1971), although we sent two letters. We also wrote to the authors of Olivieri 1987 to clarify the error measurement used, but we received no reply. Pharmaceutical companies notified us of two studies (Meister 1986; Meister 1999); the former was unpublished. They also provided further information on four studies (Meister 1986; Meister 1999; Nowak 1999; Pela 1999). In 2008 we contacted an author of the COOPT study, 'A double-blind placebo-controlled trial comparing the efficacy and cost-effectiveness of inhaled fluticasone propionate versus oral $\mathrm{N}$-acetylcysteine in the treatment of patients with COPD in general practice' (Clinical Trials identifier: NCT00184977), which was conducted from 1998 to 2003 , to ascertain whether any data might be made available for this review. This study has now been published and is included in the review (Schermer 2009). In 2012, we contacted the lead author of Decramer 2005 to clarify conflicting information on quality of life in the published report; the lead author helpfully provided us with information derived from the St George's Respiratory Questionnaire (SGRQ).

In 2014, we wrote to Dr De Backer to request additional details on the secondary outcomes of spirometry and quality of life (De Backer 2013), but we received no response. As this was a small cross-over study with few outcomes of relevance to this review, we have not pursued this. Dr Zheng provided the appendix to Zheng 2014, which contained further details on study design and outcomes. In response to another request, Dr Zheng provided standard deviations (SDs) of exacerbation rates and total SGRQ, as well as mean (SD) end of study $\mathrm{FEV}_{1}$ and FVC values.

\section{Included studies}

By 2019, this review included 38 randomised controlled trials (RCTs), which had recruited a total of 10,377 participants. We provide full details of each study in Characteristics of included studies and an overview in Table 1.

A total of 15 studies examined use of mucolytics in people with COPD only (Bachh 2007; Dal Negro 2017; De Backer 2013; Decramer 2005; Fukuchi 2016; Malerba 2004; Moretti 2004; Nowak 1999; Pela 1999; Roy 2014; Tse 2013; Worth 2009; Xu 2014; Zheng 2008; Zheng 2014). The other studies involved people with chronic bronchitis, COPD, or both.

All but four studies were randomised, double-blind, and placebocontrolled and used a parallel-group design. Blinding was not described in Xu 2014. Study duration ranged from 2 to 36 months. Fourteen studies had a run-in period (Allegra 1996; Boman 1983; Dal Negro 2017; Ekberg-Jansson 1999; Fukuchi 2016; Malerba 2004; McGavin 1985; Meister 1999; Moretti 2004; Olivieri 1987; Schermer 2009; Tse 2013; Zheng 2008; Zheng 2014). Four studies were described as randomised and placebo-controlled but not as double-blind. One of these was labelled as 'open' (Pela 1999), and two (Bachh 2007; Roy 2014) were 'single-blind' trials. The fourth was a randomised cross-over trial (De Backer 2013). As a result of the potential for bias, these are reported separately in analyses of primary outcomes.

In one study conducted in primary care practices (Schermer 2009), investigators compared NAC $600 \mathrm{mg}$ daily versus placebo as well as inhaled fluticasone $500 \mu \mathrm{g}$ twice daily in a three-arm study of double-dummy design. This review used data from NAC and placebo arms only.

\section{Inclusion and exclusion criteria}

All studies indicated that participants fulfilled criteria for chronic bronchitis, COPD, or both (except Nowak 1999, which has been published in abstract form only). Exclusion criteria varied, and 
some studies did not report whether patients with other respiratory illnesses were excluded.

\section{Lung function}

All but two studies - Grassi 1976 and Parr 1987 - reported baseline lung function using PEFR, $\mathrm{FEV}_{1}$ or $\mathrm{FEV}_{1} \%$ predicted. When studies reported pre-bronchodilator and post-bronchodilator lung function, we used the latter.

\section{Age of participants}

The mean age of participants ranged from 40 to 71 years. Most studies had an upper age limit for participants.

\section{Gender of participants}

All but three of the studies reported the proportion of males included in the study. This ranged from $44 \%$ to $93 \%$. In another study, "almost all" of the participants were reported as male.

\section{Smokers}

All but five studies reported the percentage of current smokers or ex-smokers, which ranged from $55 \%$ to $100 \%$.

\section{Mucolytics and dose}

In 21 studies, the mucolytic used was $\mathrm{N}$-acetylcysteine (NAC). Other treatments studied included carbocysteine $(\mathrm{N}=3)$, ambroxol $(\mathrm{N}=$ 3), erdosteine $(N=2)$, sobrerol $(N=1)$, carbocysteine-sobrerol $(N=$ $1)$, carbocysteine-lysine $(n=1)$, letosteine $(N=1)$, cithiolone $(N=1)$, iodinated glycerol $(\mathrm{N}=1), \mathrm{N}$-isobutyrylcysteine $(\mathrm{NIC})(\mathrm{N}=1)$, myrtol $(\mathrm{N}=1)$, and cineole and lysozyme $(\mathrm{N}=1)$.

Of the 21 studies of NAC, three used a total dose of $400 \mathrm{mg} /$ day (Babolini 1980; Boman 1983; Borgia 1981); 11 used a total dose of 600 mg/day (Bachh 2007; Decramer 2005; Grassi 1976; Jackson
1984; McGavin 1985; Meister 1986; Nowak 1999; Parr 1987; Pela 1999; Rasmussen 1988; Schermer 2009); five used 1200 mg/day (Hansen 1994; Roy 2014; Tse 2013; Xu 2014; Zheng 2014); one used $1800 \mathrm{mg} /$ day (De Backer 2013; ); and one used 3600 mg/day (Johnson 2016).

\section{Size and duration}

Study size ranged from 12 participants in De Backer 2013 to 1006 participants in Zheng 2014. Duration ranged from 2 months in Petty 1990 and Johnson 2016 to 36 months in Decramer 2005 and Schermer 2009. The mean duration of treatment, weighted by study size, was 9.4 months. Over a third of participants were enrolled in studies lasting 12 months or longer.

\section{Countries}

Twelve studies were conducted only in Italy, four in the United Kingdom, four in Germany, four in China, four in several European countries, three in Scandinavia, two in India, two in the United States, and one each in The Netherlands, Belgium, and Japan.

\section{Funding}

We have extracted and presented information on study funding since the 2014 update. A majority of studies included since 2014 report pharmaceutical sponsorship, with the exception of Johnson 2016, Roy 2014, and Xu 2014.

\section{Excluded studies}

We excluded 20 studies after scrutiny of the full text. See Characteristics of excluded studies for the reasons for exclusion.

\section{Risk of bias in included studies}

Details of our risk of bias judgements are presented in Characteristics of included studies and in an overview in Figure 4. 
Figure 4. 'Risk of bias' summary: review authors' judgements about each risk of bias item for each included study.

\begin{tabular}{|c|c|c|c|c|c|c|}
\hline & 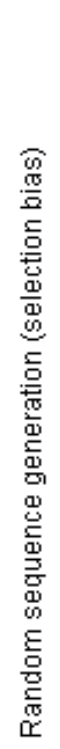 & 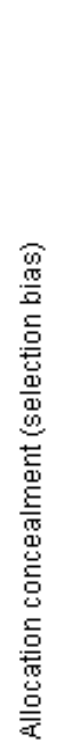 & 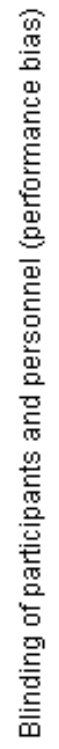 & 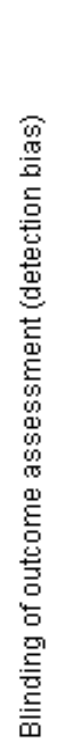 & 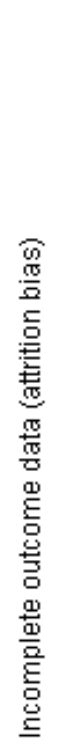 & 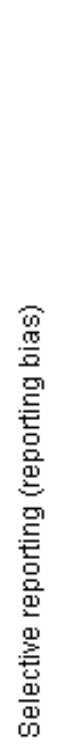 \\
\hline Allegra 1996 & + & $?$ & $\odot$ & $\odot$ & $\odot$ & + \\
\hline Babolini 1980 & $?$ & $?$ & $\odot$ & $\odot$ & $\odot$ & $\oplus$ \\
\hline Bachh 2007 & $?$ & $\odot$ & $\odot$ & $\odot$ & + & + \\
\hline Boman 1983 & $\Theta$ & $\Theta$ & ? & $?$ & $?$ & $\odot$ \\
\hline Bontognali 1991 & $?$ & $?$ & $\oplus$ & $\odot$ & + & $?$ \\
\hline Borgia 1981 & ? & $?$ & $\oplus$ & $\odot$ & $?$ & + \\
\hline Castiglioni 1986 & - & - & ? & ? & + & + \\
\hline Cegla 1988 & $?$ & $?$ & + & $\odot$ & $?$ & ? \\
\hline Cremonini 1986 & ? & ? & + & $\odot$ & + & ? \\
\hline Dal Negro 2017 & + & + & + & + & ? & + \\
\hline De Backer 2013 & ? & - & $\odot$ & $\Theta$ & + & $\Theta$ \\
\hline Decramer 2005 & + & + & + & $\odot$ & $\Theta$ & + \\
\hline Ekberg-Jansson 1999 & $?$ & $?$ & $\oplus$ & + & $\Theta$ & $\odot$ \\
\hline Fukuchi 2016 & + & + & + & + & + & + \\
\hline Grassi 1976 & ? & ? & + & $?$ & ? & + \\
\hline Grassi 1994 & $?$ & ? & + & $\odot$ & $\odot$ & $\odot$ \\
\hline Grillage 1985 & $?$ & $?$ & + & + & $?$ & + \\
\hline Hansen 1994 & + & $?$ & + & + & - & + \\
\hline Jackson 1984 & ? & ? & $\odot$ & $\odot$ & $\Theta$ & ? \\
\hline Johnson 2016 & + & $\odot$ & + & $\odot$ & $\odot$ & $\odot$ \\
\hline
\end{tabular}


Figure 4. (Continued)

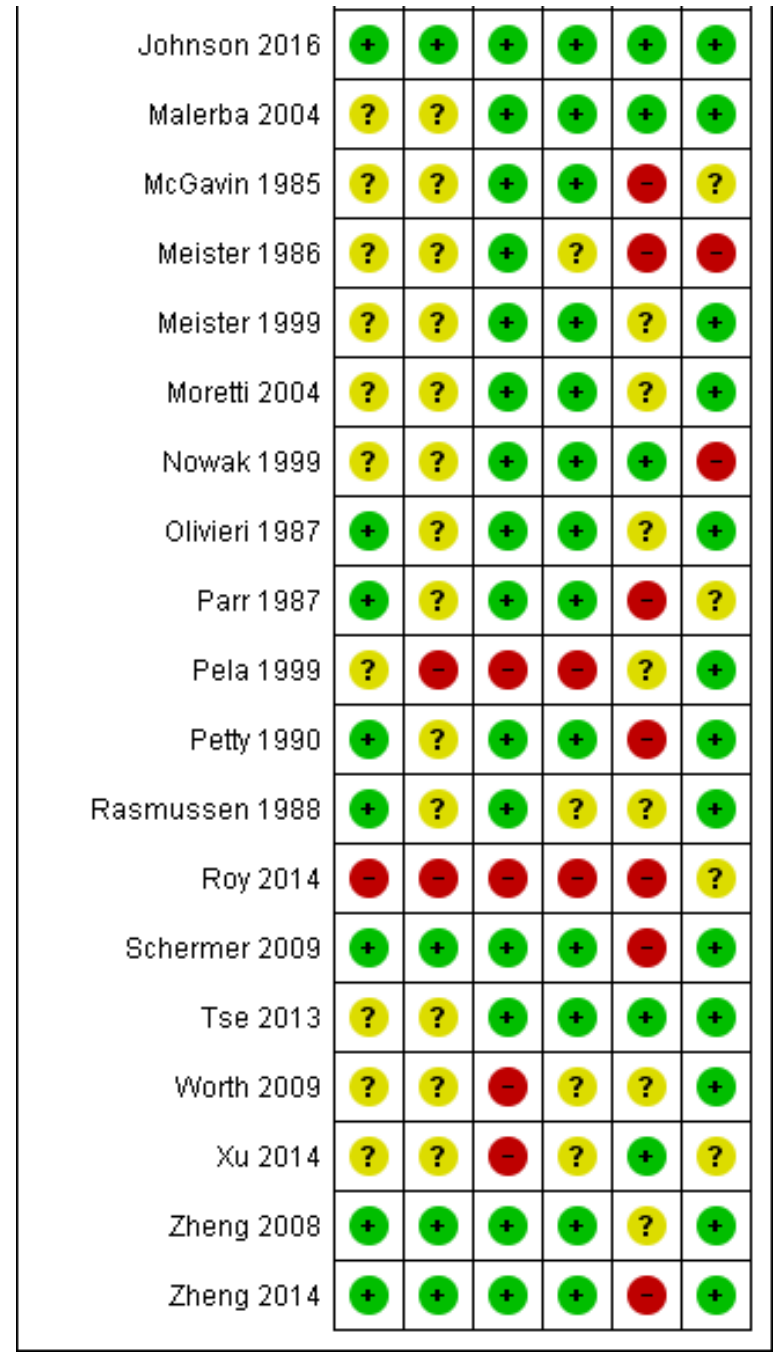

\section{Allocation}

Potential for bias in most studies was regarded as unclear, in that study authors stated that the study was randomised but did not indicate how this was achieved, where it was done, or how it was concealed. Seven studies were judged to be at low risk of bias for both random sequence generation and allocation concealment (Dal Negro 2017; Decramer 2005; Fukuchi 2016; Johnson 2016; Schermer 2009; Zheng 2008; Zheng 2014). Six studies were judged to be randomised but provided insufficient details about allocation concealment (Allegra 1996; Hansen 1994; Olivieri 1987; Parr 1987; Petty 1990; Rasmussen 1988). Six studies were judged to be at high risk of bias for one or both domains (Bachh 2007; Boman 1983; Castiglioni 1986; De Backer 2013; Pela 1999; Roy 2014).

Most studies reported baseline characteristics of treatment groups, which were well matched at baseline.

\section{Blinding}

Most studies $(\mathrm{N}=30)$ reported that the placebo was identical in appearance to the active treatment and therefore were judged to be at low risk of performance bias. Six studies were regarded as high risk, which related largely to lack of blinding, although Xu 2014 provided no description of blinding, and so an open-label policy must be assumed (Bachh 2007; De Backer 2013; Pela 1999; Roy 2014; Worth 2009; Xu 2014).

Blinding of outcome assessors was less well described, but 27 studies described adequate procedures, allowing us to judge these as having low risk of bias. Four studies were at high risk of bias and seven studies reported insufficient details about detection bias to permit a judgement.

\section{Incomplete outcome data}

Reported dropout ranged from 0\% in Bachh 2007, Bontognali 1991, Cremonini 1986, and Xu 2014 to $37 \%$ in the three-year BRONCUS study (Decramer 2005), and this rate was given as $43 \%$ in another three-year study conducted in a general practice setting (Schermer 2009). When the rate exceeded $20 \%$, we considered a high-risk rating but also took into account whether numbers of dropouts were balanced between arms, and whether the reasons given for dropout were similar. We judged 13 studies to be at high risk (Allegra 1996; Babolini 1980; Decramer 2005; Ekberg-Jansson 1999; Hansen 1994 Jackson 1984; McGavin 1985; Meister 1986; Parr 1987; Petty 1990; Roy 2014; Schermer 2009; Zheng 2014). We judged 12 studies to be at low risk as dropout either was low or had been sufficiently 
well described that we were confident the results of the study were unlikely to be impacted (Bachh 2007; Bontognali 1991; Castiglioni 1986; Cremonini 1986; De Backer 2013; Fukuchi 2016; Grassi 1994; Johnson 2016; Malerba 2004; Nowak 1999; Tse 2013; Xu 2014). We judged the remaining studies to be at unclear risk because dropouts were not clearly reported or were sufficiently high to raise concern, even if numbers and reasons were balanced.

In most of the older studies and in Roy 2014, analyses were performed on participants who completed the study (per protocol), whereas in more recent studies, analyses tended to be performed on an intention-to-treat basis.

\section{Selective reporting}

Three studies were graded as high risk: two because they were unpublished (Meister 1986; Nowak 1999), and one because study authors did not report all study outcomes (De Backer 2013). Most of the other studies reported sufficient details that we could make a judgement of low risk of bias.

\section{Other potential sources of bias}

None were noted.

\section{Effects of interventions}

See: Summary of findings for the main comparison Mucolytic compared to placebo for chronic bronchitis or chronic obstructive pulmonary disease

\section{Mucolytic versus control}

\section{Exacerbations}

\section{Patients with no exacerbations during study period}

The odds ratio (OR) for having no exacerbations over the entire study period when treatment with mucolytics was provided in double-blind trials was increased compared with placebo (Peto OR $1.69,95 \%$ confidence interval $(\mathrm{Cl}) 1.53$ to 1.88 ; participants $=6460$; studies = 26; $I^{2}=62 \%$; Figure 5; Analysis 1.1; moderate-certainty evidence). This yielded a number needed to treat for an additional beneficial outcome (NNTB) of 8 ( $95 \% \mathrm{Cl} 7$ to 10 ; Figure 6). Inclusion of single-blind studies in the analysis had a minimal impact on the pooled effect (Peto OR 1.73, $95 \% \mathrm{Cl} 1.56$ to 1.91; participants $=6723$; studies $\left.=28 ; I^{2}=62 \%\right)$. We also conducted a sensitivity analysis including only the studies judged to be at low risk of selection bias; this substantially reduced the number of studies in the metaanalysis, and the effect was attenuated (Peto OR $1.15,95 \% \mathrm{Cl} 0.96$ to 1.37 ; participants $=2353$; studies $=5 ; I^{2}=40 \%$ ). However, removing the eight studies included in this analysis judged to be at high risk of attrition bias had little impact on the pooled effect estimate (Peto OR $1.84,95 \% \mathrm{Cl} 1.62$ to 2.09 ; participants $=4141$; studies $=20 ; I^{2}=$ $50 \%)$. 
Figure 5. Forest plot of comparison: 1 Mucolytic versus placebo, outcome: 1.1 Participants with no exacerbations in study period.

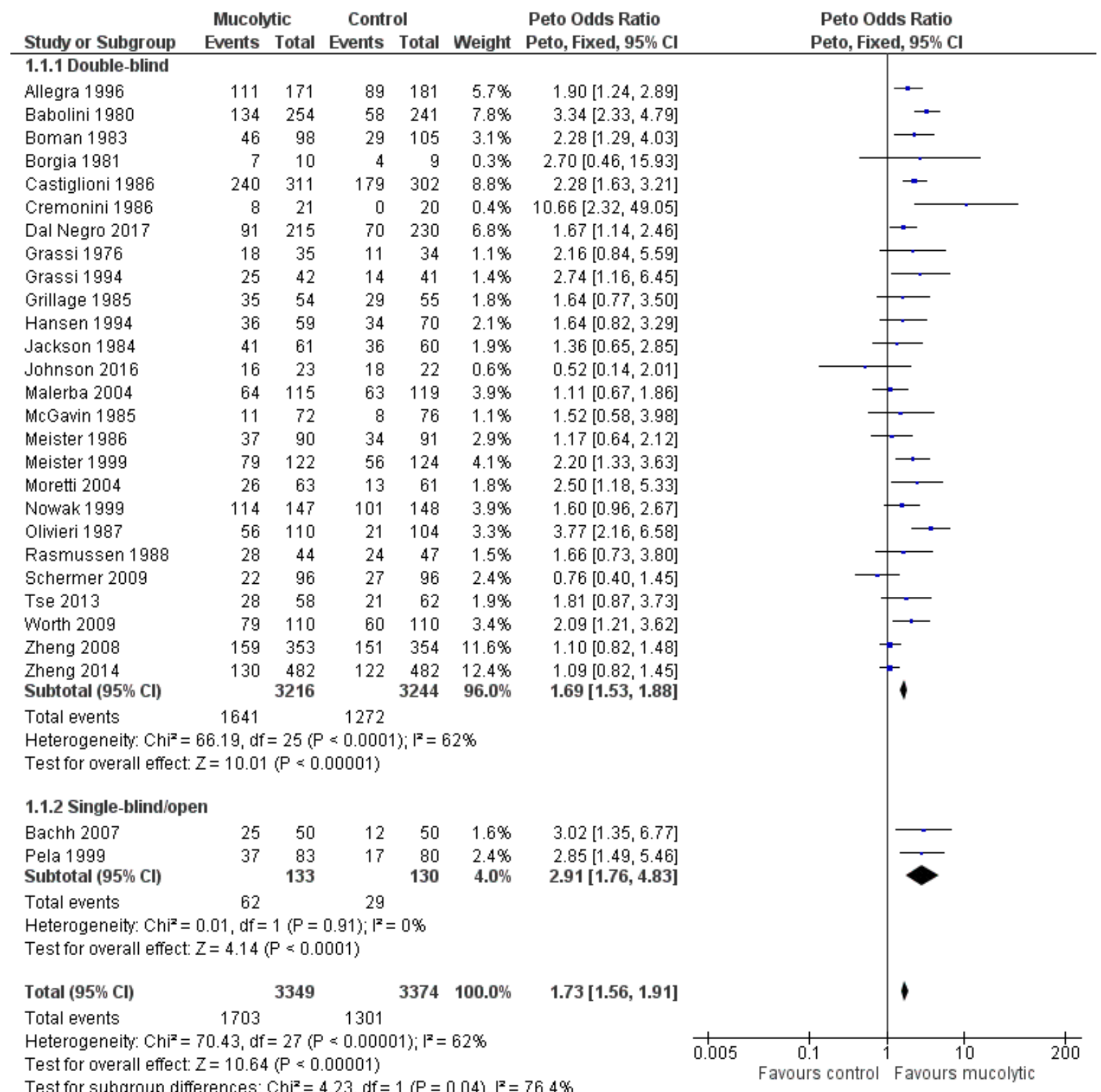


Figure 6. In the control group, 39 of 100 people were free from exacerbations over 9 months (represented by green faces) compared with 52 ( $95 \% \mathrm{Cl} 49$ to 55) of 100 for the mucolytic group (represented by green plus yellow faces).

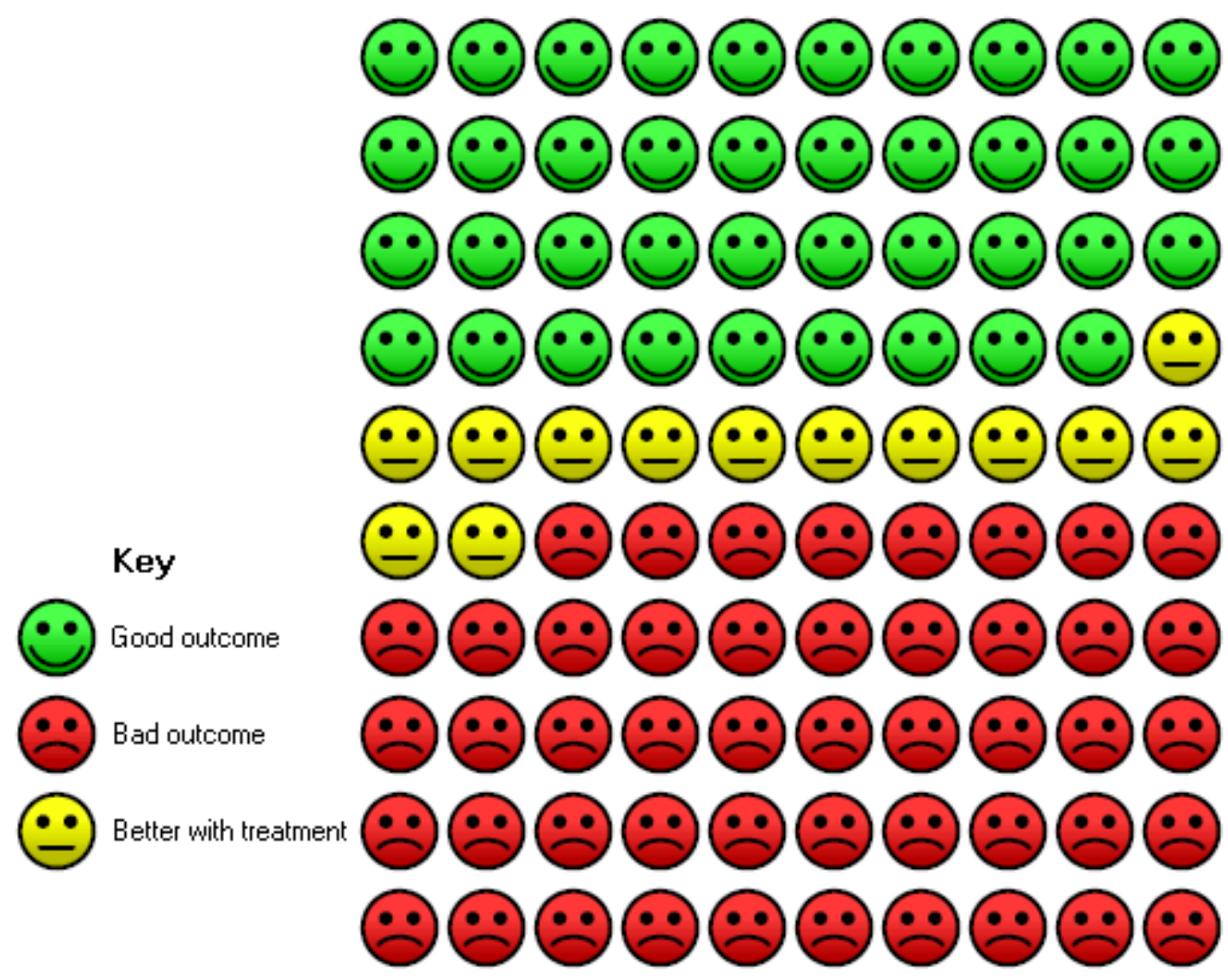

As heterogeneity in this result is high $\left(I^{2}=62 \%\right)$, we carried out a post hoc subgroup analysis showing results of double-blind trials ordered by year of publication and subgrouped by decade of publication (Analysis 1.2; Figure 7). This revealed a tendency for more recent studies to provide more conservative results: studies published before 1990 (Peto OR 2.34, 95\% Cl 1.97 to 2.79) and between 1990 and 1999 (Peto OR 1.91, 95\% Cl 1.50 to 2.44) have a greater effect size than those published between 2000 and 2009 (Peto OR 1.24, 95\% Cl 1.01 to 1.54) or since 2010 (Peto OR 1.28, $95 \% \mathrm{Cl} 1.03$ to 1.59 ). It is also notable that of the six studies with adequate allocation concealment (Dal Negro 2017; Decramer 2005; Johnson 2016; Schermer 2009; Zheng 2008; Zheng 2014), only Dal Negro 2017 reported a notable benefit of treatment in preventing exacerbations. 
Figure 7. Forest plot of comparison: 1 Mucolytic versus placebo, outcome: 1.2 Participants with no exacerbation by decade; double-blind trials only.

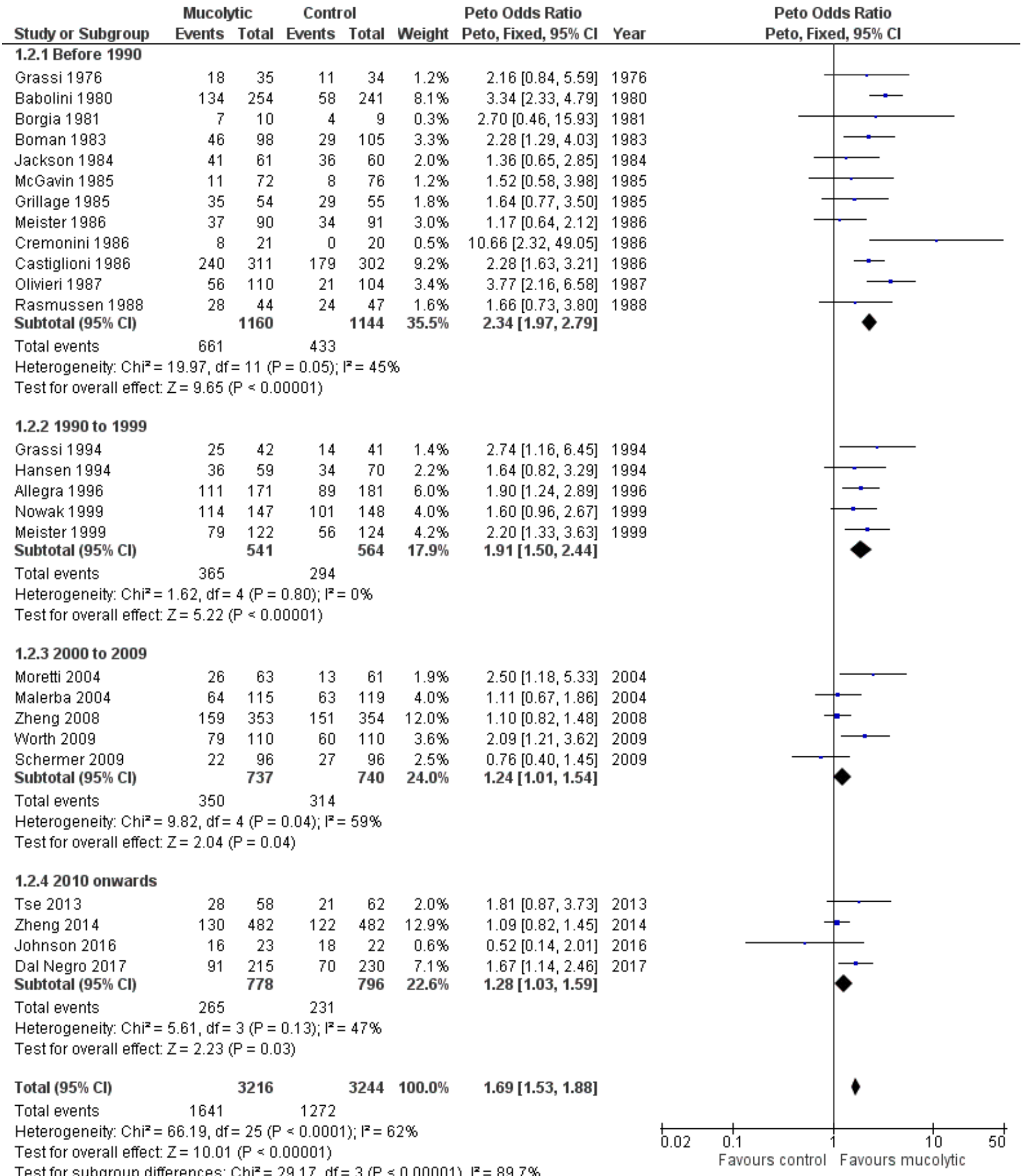

We carried out a separate analysis of studies conducted during winter months only and observed a larger effect size when compared to all studies (Peto OR 2.20, 95\% Cl 1.93 to 2.51; participants $=4007$; studies $=21 ; I^{2}=19 \%$; Analysis 1.3$)$. When subgrouped by dose or type of mucolytic, we did not observe a consistent effect ( $1^{2} 62 \%$, Analysis 1.4 ). Overall we observed significant benefits over placebo for lower doses of NAC and carbocysteine,. The "other" mucolytic category also showed benefit compared to placebo; this category included studies of ambroxol $(\mathrm{N}=2)$; erdosteine $(\mathrm{N}=1)$; letosteine $(\mathrm{N}=1)$; sobrerol $(\mathrm{N}=$ $1)$; myrtol $(\mathrm{N}=1)$; and cineole $(\mathrm{N}=1)$. 
Studies with participants with on average better lung function at baseline found greater benefit from mucolytics when compared to those with on average poorer lung function $>50 \%$ predicted vs $\leq 50 \%$ predicted; test for subgroup differences: $\mathrm{Chi}^{2}=4.14 \mathrm{df}=$ $1\left(P=0.04 ; I^{2}=75.9 \%\right.$; Analysis 1.5$)$. However, this result should be interpreted with caution as the poorer lung function subgroup contained only four studies.

Studies of greater duration on average had a lesser effect than those of shorter duration; the OR for studies $\geq 12$ months was 1.16 (95\% 0.98 to 1.37 ) compared to $2.14(95 \% \mathrm{Cl} 1.62$ to 2.82$)$ and 2.20 (95\% $\mathrm{Cl} 1.91$ to 2.54) for up to three months and three to 12 months, respectively (test for subgroup differences: $\mathrm{Chi}^{2}=35.72, \mathrm{df}=2(\mathrm{P}<$ 0.00001; Analysis 1.6).
We also observed a larger effect among studies conducted in Italy compared to those not conducted in Italy (test for subgroup differences: $\mathrm{Chi}^{2}=25.94, \mathrm{df}=1(\mathrm{P}<0.00001$; Analysis 1.7). This analysis was carried out as it has been noted in the past that some of the earlier trials of mucolytics in Italy were reporting greater effects than trials conducted elsewhere, We also noted a larger effect in those studies in which history of an exacerbation was not a requirement for study entry compared to those where it was (test for subgroup differences: $\mathrm{Chi}^{2}=12.51, \mathrm{df}=1(\mathrm{P}=0.0004$; Analysis 1.8).

A funnel plot for this outcome gave no clear indication of publication bias (Figure 8).

Figure 8. Funnel plot of comparison: 1 Mucolytic versus placebo, outcome: 1.1 Participants with no exacerbations in study period.

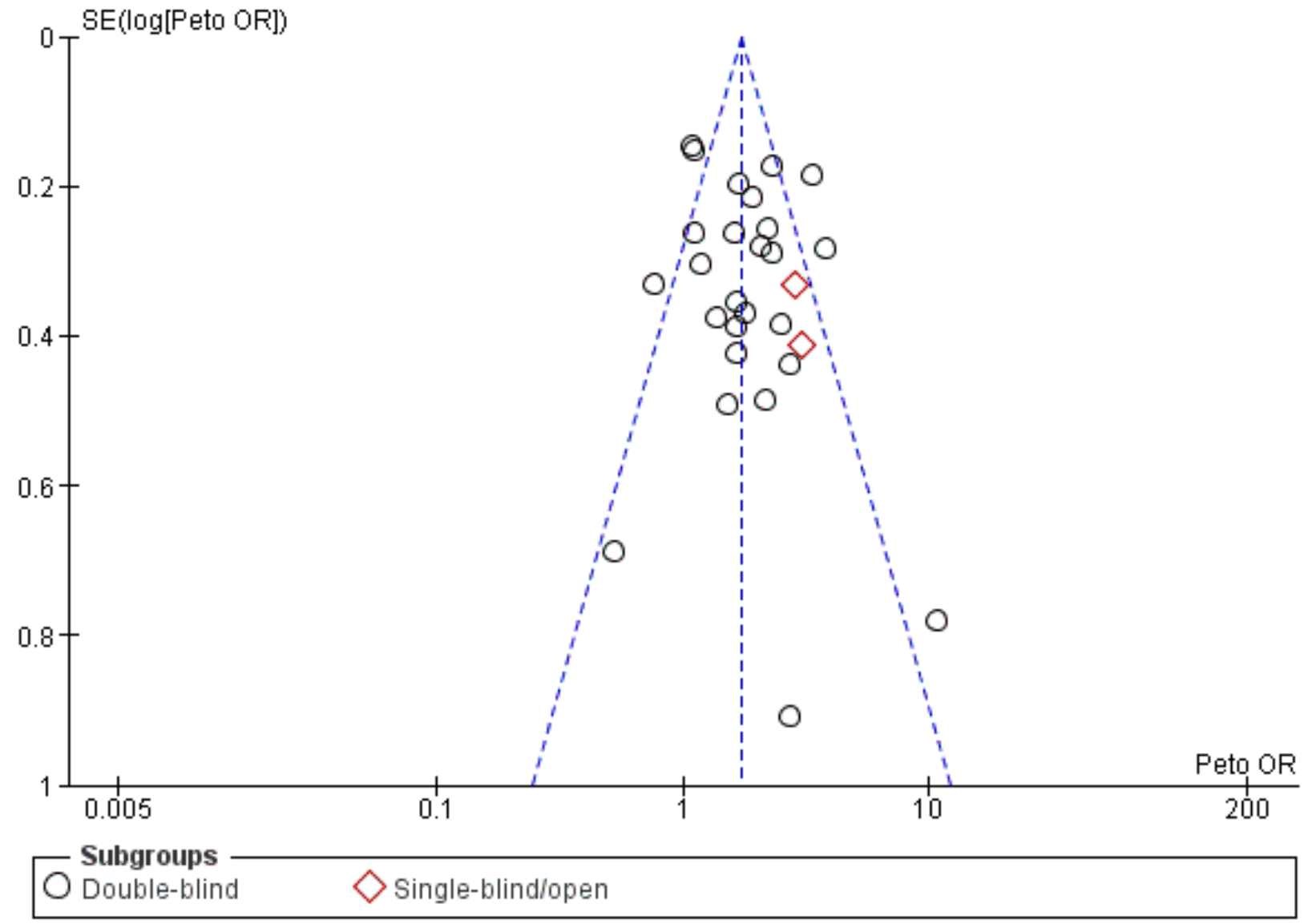

\section{Exacerbations in patients by use of concomitant inhaled corticosteroids (ICS)}

Subgrouping studies for this outcome according to whether ICS were or were not allowed (or unclear) did not suggest that this was an important effect modifier, and the test for subgroup differences was negative (test for subgroup differences: $\mathrm{Chi}^{2}=1.64, \mathrm{df}=2 ; \mathrm{P}=$ 0.44; Analysis 1.9).

\section{Time to first exacerbation}

Sufficient data with which to perform a meta-analysis are not yet available for this clinically relevant outcome. Post hoc analysis of the EQUALIFE study revealed that participants given erdosteine had a significantly longer time until their first exacerbation compared with those given placebo, with a hazard ratio of $0.639(95 \% \mathrm{Cl}$ 0.416 to 0.981 ) (Ballabio 2008). Longer time to first exacerbation was also reported by Nowak 1999. In that study, participants with COPD treated with NAC had a mean of 139 days (SD 68) to first exacerbation versus 108 (SD 79) days for those given placebo ( $P$ $<0.05$ ). More recently, Zheng 2014, Dal Negro 2017, and Fukuchi 2016 reported time to first exacerbation. Zheng 2014 reported no differences between time to first exacerbation in NAC- or placebotreated groups, but time to second and third exacerbations was 
shorter in the placebo group. Dal Negro 2017 reported increased time to first exacerbation in the erdosteine group compared to the placebo group, but this did not reach statistical significance (Kaplan-Meier plot of probability, $\mathrm{P}=0.07$ ). Fukuchi 2016 reported the median time to first exacerbation as 179 days in the lysozyme group and 210 days in the placebo group (hazard ratio 1.06; $\mathrm{P}=$ $0.626)$.

\section{Number of exacerbations per patient per month}

We calculated and meta-analysed the number of exacerbations per patient per month as a primary outcome in previous versions of this review. For the 2019 update, we decided not to update these analyses due to concerns about high levels of heterogeneity, the need to impute much of the data, and the likely skew of this measure. Instead, we present the data in a table (Analysis 1.10). The mean difference in number of exacerbations per patient per month favoured the mucolytic intervention in most studies, but this finding should be interpreted with caution in light of the caveats already mentioned.

\section{Number of days of disability per participant per month ('sick days')}

We were able to meta-analyse data from nine studies, showing a significant reduction of 0.43 days of disability per participant per month with mucolytic therapy $(95 \% \mathrm{Cl}-0.56$ to $-0.30 ; 9$ studies, 2259 participants; Analysis 1.11; moderate-certainty evidence) compared with placebo. This finding was associated with a high level of heterogeneity $\left(I^{2}=61 \%\right)$.

The following studies reported information that we were unable to meta-analyse. Cegla 1988 reported total days off sick per group over the two years and noted that this did not differ significantly between the two treatments ( 1071 days in the ambroxol group and 979 in the placebo group over two years; participants $=180$ ). Nowak 1999 reported the cumulative exacerbation days per group as 462 days in the NAC group and 776 days in the placebo group over eight months (participants $=295$ ). Petty 1990 reported the mean duration in days of exacerbations between week 4 and week 8 of the trial. The mean duration in the iodinated glycerol group was 6.3 compared to 10.2 in the placebo group; the $P$ value for the difference was reported as 0.029 (participants $=376$ ). Moretti 2004 did not report total 'sick days'; however, investigators did report the numbers of individuals losing workdays: seven in the erdosteine group and 10 in the placebo group, for a mean number of days lost per person of 0.8 and 1.1 , respectively.

In the three studies that reported it, a mean reduction of 0.53 days on antibiotics per participant per month was observed $(95 \% \mathrm{Cl}$ -0.76 to $-0.31 ; 3$ studies; 714 participants; Analysis 1.12). These were older studies that included participants with chronic bronchitis. In the study of Meister 1999, 6/31 (52\%) participants in the myrtol group with exacerbations needed antibiotics, compared with 30/49 $(61 \%)$ in the placebo group. Courses of antibiotics were longer in the placebo group. The percentage of participants who needed antibiotics for longer than seven days was 37\% in the myrtol group and $77 \%$ in the placebo group. Malerba 2004 reported no differences between ambroxol and placebo in terms of duration of courses of antibiotic treatment, working days lost, or number of days of hospitalisation (no data given). Moretti 2007 used post hoc analyses to report that compared with placebo, erdosteine use was associated with relatively fewer antibiotic courses (32\%) and shorter durations of treatment (15\%). The mean number of antibiotic courses per participant treated with erdosteine was also lower than for those given placebo (0.5 (SD 0.7) vs 0.7 (SD 0.7); $\mathrm{P}=$ 0.045).

\section{Lung function}

FEV $_{1}$

Fourteen studies reported $\mathrm{FEV}_{1}$ in $\mathrm{L}$ at the end of the study. The pooled effect favours mucolytics over placebo, but the effect size is small (mean difference (MD) $0.04 \mathrm{~L}, 95 \% \mathrm{Cl} 0.01$ to 0.07 ; participants $=3310$; Analysis 1.13; moderate-certainty evidence). We observed substantial heterogeneity in this outcome $\left(I^{2}=70 \%\right)$, and so results should be interpreted with caution. Furthermore, this analysis includes data from the Moretti 2004 study, which reported a significant difference (> $300 \mathrm{~mL}$ ) between mucolytic and placebo groups at the end of the study; however the mucolytic group had higher baseline lung function, and the net change was therefore closer to $200 \mathrm{~mL}$. If this study is removed from the analysis, a significant difference between groups is no longer observed and heterogeneity is removed.

Nowak 1999 reported $\mathrm{FEV}_{1}$ change from baseline in $\mathrm{L}$ but without variance, and so we were unable to include the results in the metaanalysis. Trialists reported $0.225 \mathrm{~L}$ improvement in the NAC group $(n=33)$, compared to $0.062 \mathrm{~L}$ in the placebo group $(n=47)$.

Of note, two three-year studies are included in this analysis. The BRONCUS study of Decramer 2005 found no differences between NAC-treated and placebo-treated groups over three years in terms of decline in $\mathrm{FEV}_{1}, \mathrm{FVC}$, or diffusing capacity of the lung for carbon monoxide (DLCO). $\mathrm{FEV}_{1}$ declined by $54 \mathrm{~mL}$ and $47 \mathrm{~mL}$, respectively, in the two groups. Study authors reported possible benefit of NAC for functional residual capacity (FRC), with a greater reduction in this measure. The difference was $-0.374 \mathrm{~L}$ (SD 1.03; $\mathrm{P}<0.01$ ) for NAC-treated participants, whereas for those treated with placebo, a decrease of only $0.008 \mathrm{~L}$ was reported. The other three-year study found no differences between groups in lung function at the end of the study (Schermer 2009). In the NAC-treated group, FEV ${ }_{1}$ declined by $64 \mathrm{~mL}$, and in the placebo group, by $60 \mathrm{~mL}$. The decline in FVC was $79 \mathrm{~mL}$ and $65 \mathrm{~mL}$, respectively.

In the HIACE study of Tse 2013, a significantly higher mean FEV was reported for the NAC group at the end of the study, but this reflected differences at baseline, with no significant differences in the amount of change reported between groups. On the other hand, researchers reported significantly greater changes in the NAC group than in the placebo group for two measures of small airways function: forced expiratory flow at $25 \%$ to $50 \%\left(\mathrm{FEF}_{25-50}\right)(\mathrm{P}=0.037)$ and forced oscillation technique (FOT) $(P=0.04)$, as well as for airways resistance $(P=0.01)$.

\section{Percent predicted FEV}

This outcome was reported by only four studies. Although the pooled effect favours mucolytics, this is driven by one study: Xu 2014, which was not blinded (MD 4.79, 95\% Cl 1.97 to 7.62; participants $=414$; Analysis 1.14), and again, we detected substantial heterogeneity $\left(I^{2}=89 \%\right)$.

\section{Peak expiratory flow rate}

Peak expiratory flow rate was reported by one study only (Grillage 1985). The result favours mucolytics but is very uncertain (MD 19.00, $95 \% \mathrm{Cl}-22.70$ to 60.70 ; participants = 109; Analysis 1.15). 


\section{Forced vital capacity}

Twelve studies reported this outcome, and the pooled effect revealed benefit of $50 \mathrm{~mL}$ of mucolytics over placebo (MD 0.05, $95 \%$ $\mathrm{Cl}-0.00$ to 0.10 ; participants $=3127 ; \mathrm{I}^{2}=0 \%$; Analysis 1.16$)$, but the confidence interval includes no difference between groups.

In summary, it is likely that if mucolytics affect disease progression in chronic bronchitis or COPD, changes are very small and are confined to as-yet small and undefined subgroups.

\section{Adverse effects}

The meta-analysis of total numbers of adverse effects favours mucolytic treatment, but with some heterogeneity (OR $0.84,95 \% \mathrm{Cl}$ 0.74 to $0.94 ; \mathrm{I}^{2}=46 \%$ participants $=7264$; studies $=24$; Analysis 1.17 ; moderate-certainty evidence). If a random-effects model is used, this finding is less precise and the confidence interval includes no difference (OR $0.83,95 \% \mathrm{Cl} 0.69$ to 1.00 ).

Moreover, this analysis does not include data from several large studies. Parr 1987 reported 1263 events in 258 participants in the mucolytics group (mean 4.9 per participant) and 1202 events in 268 participants in the placebo group (mean 4.5 per participant). Decramer 2005 reported 1428 events in 256 participants in the mucolytics group (mean 5.58 per participant) and 1381 events among 267 participants in the placebo group (mean 5.17 per participant). None were thought to be drug-related. Similar numbers in each group were admitted to hospital (55 and 69, respectively). Another study described 54 events in 59 participants in the mucolytic group and 66 events in 57 participants in the placebo group (Rasmussen 1988). Meister 1999 reported 201 adverse effects in 122 participants in the mucolytic group (1.65 per participant) and 170 adverse effects in 124 participants in the placebo group (1.37 per participant). These studies could not be included in the meta-analysis because event rates exceeded numbers included in the treatment groups. Malerba 2004 also reported no greater risk of events and no greater severity of events with mucolytic treatment compared with placebo.

\section{Hospitalisation}

Comparative data were provided by five studies (Decramer 2005; Johnson 2016; Moretti 2004; Tse 2013; Zheng 2014). The Peto OR for hospitalisation with mucolytic treatment compared with placebo was $0.68(95 \% \mathrm{Cl} 0.52$ to 0.89; participants = 1833; Analysis 1.18; moderate-certainty evidence); however, moderate heterogeneity in this result was observed $\left(I^{2}=43 \%\right)$, and benefit was seen in only the two smaller studies (Moretti 2004; Tse 2013). Malerba 2004 reported no significant differences in hospitalisation rates but did not provide data. Bachh 2007 reported a significant reduction ( $P$ $<0.05$ ) in hospitalisation when four months of NAC treatment was provided, with 55 hospitalisations reported for 50 participants in the control group but for only 37 of 50 in the treated group. As presented, these data cannot be included in the meta-analysis because the number of events exceeds the number of participants in the control group. If a conservative estimate of hospitalisations in the control group is made by entering them as 50 (not 55), the beneficial effect of mucolytics for hospitalisation is greater (OR $0.62,95 \% \mathrm{Cl} 0.48$ to 0.80 ) but heterogeneity is increased $\left(\mathrm{I}^{2}\right.$ $=76 \%$ ). Mucolytics may be associated with a small decrease in hospitalisations.
Days in hospital were reported by Moretti 2004. In this study, participants taking erdosteine spent 70 days in hospital, compared with 163 days for the placebo group $(P=0.04)$. This represented a mean of 1.1 days per treated participant compared with 2.7 days per control participant.

\section{Mortality}

Eleven studies reported on numbers of deaths in mucolytic-treated and placebo groups, revealing no significant differences, but the confidence interval is wide (Peto OR $0.98,95 \% \mathrm{Cl} 0.51$ to 1.87 ; participants $=3527$; Analysis 1.19; moderate-certainty evidence). As no deaths were reported in either group in Johnson 2016, Xu 2014, or Zheng 2008, this information could not be incorporated into the meta-analysis.

\section{Health-related quality of life}

Although many studies reported participant and/or physician global assessments of well-being, only ten used validated tools to evaluate health-related quality of life (HRQoL) among participants with COPD. In nine studies, investigators used the St George's Respiratory Questionnaire (SGRQ; Jones 1992) (Dal Negro 2017; De Backer 2013; Decramer 2005; Johnson 2016; Moretti 2004; Tse 2013; Worth 2009; Zheng 2008; Zheng 2014). Schermer 2009 used the Chronic Respiratory Questionnaire (CRQ; Guyatt 1987). In Johnson 2016, trialists reported the Short Form-36 (SF-36) as well as SGRQ, and in Fukuchi 2016, trialists reported the COPD Assessment Test (CAT).

The SGRQ total score is derived from scores on three subscales - symptoms, activities, and impacts - to yield a score out of 100 (Jones 1992). A well person has respiratory disease scores around 7 (Jones 1992). Lower scores indicate better quality of life.

We were able to combine total scores on the SGRQ for seven studies at the end of the treatment period. Although the pooled result favoured mucolytics over placebo, the confidence interval included no difference (MD $-1.37,95 \% \mathrm{Cl}-2.85$ to 0.11 ; studies = 7 , participants $=2721$; Analysis 1.20; moderate-certainty evidence). Considerable heterogeneity among studies was apparent $\left(\mathrm{I}^{2}=\right.$ $64 \%$ ). This effect does not meet the minimum clinically important difference of -4 units on the SGRQ (Jones 2005). However it is not possible to assess the impact of mucolytics at a population level without performing a responder analysis, which we have been unable to do.

The analysis includes data from the three-year Decramer 2005 study of $600 \mathrm{mg}$ NAC daily, in which participants were evaluated with the SGRQ, although for technical reasons only about $80 \%$ of participants completed the questionnaire. During the first year of the study, participants in both treatment and placebo groups showed significantly improved scores on both scales, with no significant differences between groups (-3.76 units on NAC and -4.95 units on placebo; difference between groups 1.18; $\mathrm{P}=0.358$, as reported in the text of the paper). In the second year, this improvement tailed off again, with no differences noted between treatment groups. More participants given placebo withdrew from the trial, and dropouts had a worse SGRQ score than those who remained in the study. We have used data provided by study authors as obtained from the mixed-effects model used in this study. In a one-year study of a higher dose of NAC $(600 \mathrm{mg}$ twice daily; Tse 2013), no significant difference was observed between groups for SGRQ. 
In Zheng 2008, baseline SGRQ scores were well matched among groups. After 12 months of treatment, changes in SGRQ total scores from baseline amounted to -4.06 units in the carbocysteine group and -0.05 in the placebo group, but these values did not represent a statistically significant difference between groups $(P$ $=0.13$ ). A very large difference in SGRQ symptom domain results between the carbocysteine group (-11.34 units) and the placebo group (-3.54 units; $P=0.004)$ remains unexplained. Results from the single measurement obtained at one year in this study contrast with multiple measurements taken in Decramer 2005, by which no significant differences in symptom scores between NAC and placebo were found over time.

In Worth 2009, the mean score change at six months from baseline was -4.3 in the placebo group and -9.9 in the cineole group $(P=0.06)$. However, we judged this study to be at high risk of selection bias.

In the recent one-year Dal Negro 2017 study of erdosteine, trialists reported improvements in SGRQ in both intervention and control groups but no differences between groups. Similarly, in the eightmonth Moretti 2004 study of erdosteine, participants completed both SF-36 and the SGRQ. The erdosteine-treated group showed significant improvement in all domains of the SGRQ, as well as in total score, and no differences between treated and placebo groups were reported. Data from Moretti 2004 were not suitable for inclusion in Analysis 1.20.

In the three-year study of NAC versus placebo (Schermer 2009), the CRQ was used. Groups were well matched at baseline, with evident improvement in both groups, particularly over the first year, but this never exceeded the 0.5 unit threshold regarded as clinically significant (Guyatt 1987). At the end of the study, no significant differences in CRQ total scores were reported between groups $(\mathrm{P}=$ 0.306).

In Fukuchi 2016, CAT scores were reported. Trialists reported that quality of life in both the lysozyme group and the placebo group improved according to this measure; improvement was greater in the lysozyme group at all time points, and the difference was significant at 24 weeks but did not remain so at 52 weeks (MD -0.90, $95 \% \mathrm{Cl}-2.22$ to 0.42 ; participants $=340$; studies $=1$, Analysis 1.21 ).

Thus, considerable variation can be seen in evidence related to HRQoL, and we are not able to assess whether mucolytics had a clinically important effect on this outcome. Furthermore, and in keeping with the exacerbation outcome, more recent studies have tended to provide more conservative estimates of the impact of mucolytics on quality of life.

\section{Systemic thiol donor versus control}

One study investigated a systemic thiol donor, $\mathrm{N}$-isobutyrylcysteine (NIC), versus control (Ekberg-Jansson 1999). This trial randomised more than 600 participants with chronic bronchitis. There was no clear difference between groups for the number of participants who remained exacerbation-free (Peto OR $1.01,95 \% \mathrm{Cl} 0.74$ to 1.39; participants $=628$; Analysis 2.1), the number of exacerbations per participant per month (MD $0.01 ; 95 \% \mathrm{Cl}-0.02$ to 0.04 ), or days of disability per participant per month (MD $-0.18,95 \% \mathrm{Cl}$ -0.82 to 0.46 ; participants $=628$; Analysis 2.3). Participants in the intervention group experienced more adverse events, but the confidence interval included no difference (Peto OR $1.39,95 \% \mathrm{Cl}$ 0.98 to 1.95 ; participants $=628$; Analysis 2.4 ).

\section{DISCUSSION}

\section{Summary of main results}

The previous update of this review was performed in 2015 (Poole 2015). Since that time, a further four studies that were eligible for inclusion have been conducted (Dal Negro 2017; Fukuchi 2016; Johnson 2016; Xu 2014). The present update strengthens findings from our previous reviews indicating that participants given a mucolytic agent for an average of nine months are more likely to be exacerbation-free during that time (Peto odds ratio (OR) 1.73, $95 \%$ confidence interval $(\mathrm{Cl}) 1.56$ to 1.91$)$. For one participant to be exacerbation-free, eight ( $95 \% \mathrm{Cl} 7$ to 10$)$ had to be treated for at least nine months. Mucolytics may be associated with a reduction of approximately a half-day of disability per participant per month, but the result is heterogeneous (mean difference (MD) $-0.43,95 \% \mathrm{Cl}$ -0.56 to $\left.-0.30 ; 1^{2}=61 \%\right)$. Three studies reported days on antibiotics per participant per month, and the pooled result indicated benefit of mucolytics (MD $-0.53,95 \% \mathrm{Cl}-0.76$ to -0.31 ).

Mucolytics may be associated with a decrease in hospitalisations, although this finding is based on data from only five studies (Peto OR $0.68,95 \% \mathrm{Cl} 0.52$ to 0.89 ). With the addition of newer studies, certainty that mucolytics do not have a substantial impact on lung function decline or mortality is increasing. Mucolytics may be associated with a reduction in all adverse events, but the effect estimate includes the possibility of no difference between groups (OR $0.83,95 \% \mathrm{Cl} 0.69$ to 1.00 ). The impact on quality of life as measured by the total St. George's Respiratory Questionnaire (SGRQ) score is smaller than the minimal clinically important difference (MCID) of 4 units and also includes the possibility of no differences between groups (MD $-1.37,95 \% \mathrm{Cl}-2.85$ to 0.11 ). Furthermore, we cannot be certain about the population effect, as we were unable to carry out a responder analysis.

For many outcomes - primary and secondary - significant heterogeneity has been noted among studies; therefore the results do need to be interpreted with particular caution. The only outcomes for which heterogeneity among trials was not significant were days on antibiotics, forced vital capacity (FVC), and death during the study period. To explore causes of heterogeneity for the primary outcome of exacerbations, we performed subgroup analyses according to study date, baseline forced expiratory volume in one second ( $\mathrm{FEV}_{1}$ ) (as \% predicted), type of mucolytic, dose of mucolytic, duration of therapy, whether participants were included because they had a history of exacerbations, whether concomitant inhaled steroids were used, and the country in which the study was conducted. Heterogeneity was generally less among trials with winter treatment only and those using the same dose of $\mathrm{N}$-acetylcysteine (NAC).

The tendency for participants given mucolytics to be more likely to be exacerbation-free was seen in all studies except Schermer 2009 and Johnson 2016. Schermer 2009 was the first study that found an increased number of exacerbations in the mucolytictreated group compared with the placebo-treated group; however, this difference was not statistically significant. The exacerbation rate was generally low in this study, and data were skewed by two participants in the NAC-treated group who had very frequent exacerbations. Additionally, this study reported a high dropout rate (43\%). Johnson 2016 also reported increased exacerbations in the mucolytic group, but the result was very imprecise and was 
reported in the context of a study stopped at eight weeks due to safety concerns after only 51 participants were recruited.

However, when we performed a post hoc investigation comparing more recent study results versus those from previous decades, we found a clear reduction in the effects of treatment in more recent studies (see Figure $7 ; \mathrm{I}^{2}=89.7 \%$ between subgroups). Although all studies included in this analysis were placebo-controlled, and most were double-blind, the older studies were more difficult to judge in terms of bias (see Figure 4), and this may have led to an overestimation of treatment effect. Therefore we have a reduced level of confidence in the overall treatment effect estimate. On the other hand, internal consistency is evident in the findings, in that the effect on exacerbations rate is accompanied by a reduction in hospitalisations and a reduction in both days of disability and days on antibiotics.

Theoretical reasons have been proposed to explain why mucolytics may modify disease in ways other than by reducing exacerbations (i.e. through antioxidant and thiol donor effects). More recent studies have sought to explore whether the decline in $\mathrm{FEV}_{1}$ over time is changed by mucolytics. NAC has been used at higher doses or for longer durations without providing additional benefits, although this may be due to insufficient power to detect a difference. The reduction in exacerbation rates seen with NAC was virtually identical to that observed with other mucolytics examined as a group. The mechanisms responsible for the benefits of mucolytic treatment for exacerbation rates and days of disability cannot be identified by this review. However, lack of effect of $\mathrm{N}$ isobutyrylcysteine (NIC) (a thiol donor with antioxidant properties) on exacerbation rates or days sick raises the possibility that the actions of NAC as a thiol donor are less important in the reduction of exacerbations.

We found no evidence to suggest that mucolytics are unsafe, and findings indicate that they do not adversely affect quality of life, even though medicines need to be taken at least once a day.

\section{Overall completeness and applicability of evidence}

This review has now been updated substantively seven times. Through the process of iterative searches, we are confident that we have identified almost all the major studies with mucolytics as the intervention.

Over time, with a steady increase in the numbers of studies published, even though a significant treatment effect of mucolytics on exacerbations has always been observed, the size of this effect has decreased from that described in the original report. This trend may be observed in Figure 7, where studies have been separated by decades of publication.

We have considered below two factors that may be contributing to this observation.

\section{Improved study design, execution, and reporting over the years}

Confidence intervals are narrower, and consequently greater weight is afforded to more recent studies. The forest plot in Figure 7 has been arranged in subgroups by date and shows this trend. Part of the explanation is that more recent studies, on average, have been larger than earlier ones. Another consideration is that publication bias may have influenced reporting of results of earlier trials. This is suggested by asymmetrical funnel plots in Analysis 1.11 and Analysis 1.13 (Figure 1 and Figure 2).

Furthermore, tighter definitions of chronic obstructive pulmonary disease (COPD) have been used in later studies, which have generally included patients with, at most, moderate disease. To be included in earlier studies, patients needed only to have symptoms of chronic bronchitis, which is a clinical diagnosis. Furthermore, fewer dropouts in the intervention groups of longer studies might dilute any treatment effect, as those remaining in the study have a longer period over which to have an exacerbation recorded. Finally, as was mentioned previously, older studies may be at greater risk of selection bias, which may have inflated estimates of the treatment effect.

\section{Improved COPD care}

Comprehensive management of COPD now includes support for smoking cessation, vaccination, pulmonary rehabilitation, and use of inhaled corticosteroids (ICS), long-acting beta-agonists (LABAs), and anticholinergic agents (GOLD 2019), each of which may impact exacerbation frequency or severity.

Inhaled corticosteroids have been available for asthma since the late 1970s, but it is unlikely that they were used by participants with chronic bronchitis in trials before 1990. In most of the other studies, ICS treatment was allowed. In the present review, we divided the studies into whether cotreatment with ICS was allowed, not allowed, or unclear (Analysis 1.9). There was no significant subgroup difference $(P=0.44)$, suggesting that the effect of mucolytics is not affected by ICS use. The nature of reporting of the studies did not allow us to stratify by use of measures mentioned previously that may reduce exacerbations.

The trend in the likelihood that participants in control groups would be exacerbation-free is 38\% in pre-1990 studies, 52\% between 1990 and $2000,42 \%$ from 2000 to 2009 , and $29 \%$ from 2010 onwards (derived from Analysis 1.2). These findings suggest that up to $40 \%$ of study participants with COPD will have an exacerbation. One interpretation is that more recent studies show a trend toward improvement in overall care, but this needs follow-up.

\section{Quality of the evidence}

We graded all pooled outcomes as moderate, indicating that the true effect is likely to be close to the estimate of the effect, but there is a possibility that it is substantially different (Summary of findings for the main comparison). Our confidence in the pooled estimates was reduced by several considerations. Most outcomes were both clinically diverse and statistically heterogeneous.. Trials used a variety of types and doses of mucolytic, were conducted over two months to three years, and recruited populations with different baseline severity of COPD. Many were conducted in the 1980s and 1990s, at which time standard definitions and standard treatment for COPD differed from today. Subgroup analysis applied to our primary outcome of exacerbations explained some, but not all, the statistical heterogeneity. Therefore all outcomes, with the exception of mortality, were downgraded for inconsistency.

Although we had concerns about the conduct methods used for some of the included trials, including uncertainty about methods of allocation concealment and blinding, we did not downgrade any outcome for risk of bias, as the trials about which we had greatest concern were generally of low weight in the meta-analyses. We also 
judged 13 studies to be at high risk of attrition bias due to high or unbalanced dropout. To explore this further, we conducted a post hoc sensitivity analysis on our primary outcome (participants with no exacerbations during follow-up). Removal of studies considered to be at high risk of attrition bias had a minimal impact on the pooled effect estimate.

Funnel plots for days of disability and FEV $_{1}$ outcomes (Figure 1 and Figure 2) suggest a possible small-study effect (i.e. missing small negative trials). Removing the small positive trials from the analyses had minimal impact on the pooled result; therefore we did not downgrade for this reason. Furthermore, a funnel plot for the primary outcome participants with no exacerbation appeared symmetrical, giving no indication of publication bias (Figure 8).

We considered a downgrade for imprecision for health-related quality of life, but although the confidence interval includes no difference, both ends lie within the MCID for SGRQ, and thus we are reasonably confident that mucolytics do not have a substantial impact on quality of life. However, we did downgrade mortality for imprecision, as the confidence interval of the pooled effect estimate includes both important harm and benefit of the intervention.

Finally, although we considered indirectness on the basis of the age of some of the included studies, we did not judge our concerns to be sufficiently serious to warrant a downgrade.

\section{Potential biases in the review process}

The subgroup analysis by decade of publication is post hoc for updates from 2012 onward and should be interpreted with caution. In a few analyses, we have imputed standard deviations. When this has been done, it has been done conservatively and in accordance with accepted practices. This could have narrowed the confidence intervals for individual studies, thus increasing heterogeneity. Furthermore, the approach that we used may tend to overestimate the number of exacerbations per year in both groups, as more occur during the winter months, when many of these studies were performed.

Despite the use of a consistent approach, slight rounding errors may have been introduced by the calculation of exacerbation rates per participant per month from study data to fit into earlier versions of RevMan that allowed only two decimal points. Furthermore, we decided to remove the meta-analysis for this outcome for the 2019 update, as we made a post hoc decision that this analysis is less robust than the dichotomous exacerbation outcome. Reasons include likely skew, high heterogeneity, and reliance on calculated/ imputed data for this analysis.

\section{Agreements and disagreements with other studies or reviews}

In addition to this review, we have identified five other systematic reviews of the effects of NAC in chronic bronchitis/COPD. Our results are consistent with these findings. The largest of these reviews included 13 randomised controlled trials (RCTs) (Cazzola 2015). This meta-analysis reported that patients treated with NAC had significantly and consistently fewer exacerbations of chronic bronchitis or COPD (risk ratio (RR) $0.75,95 \% \mathrm{Cl} 0.66$ to 0.84 ).

The second review demonstrated that individuals treated with NAC were more likely to remain exacerbation-free (OR 1.56, 95\% Cl 1.37 to 1.77), with a number needed to treat for an additional beneficial outcome (NNTB) of $6(95 \% \mathrm{Cl} 5$ to 9) (Stey 2000). Participants were more likely to report improvement in symptoms with NAC (OR 1.78, 95\% Cl 1.54 to 2.05) than with placebo. The third review analysed nine trials that had been included in both Stey 2000 and this Cochrane review, and confirmed a significant effect on exacerbations (standardised mean difference (SMD) $-1.37,95 \% \mathrm{Cl}$ -1.5 to -1.25$)$ (Grandjean 2000). A meta-analysis published in 2017 investigating the effects of NAC on exacerbations of COPD showed that both high-dose (RR 0.90, 95\% Cl 0.82 to 0.996 ) and low-dose (RR $0.83,95 \% \mathrm{Cl} 0.69$ to 0.99 ) NAC reduced COPD exacerbations (Fowdar 2017). Therefore, the review concluded that long-term therapy may reduce risk of COPD exacerbation, which is in agreement with our findings.

The fifth review investigated the use of mucolytics and antioxidants for COPD (Li 2015; abstract only available in English). The review includes 10 RCTs and reports that mucolytics and antioxidants reduce the number of exacerbations per patient per year compared to placebo, and that high-dose NAC may be more effective than lowdose, although a test for subgroup differences was not reported in the abstract.

The analyses in this review suggest that mucolytics might, in addition, have an effect on duration and severity of exacerbations that do occur, and on the likelihood of taking antibiotics. Data from four studies suggest that mucolytics are associated with decreased hospitalisation rates. It would be helpful if future studies looked at this outcome, as this is where most costs associated with more severe disease are incurred. Few other pharmacological treatments have been shown to reduce hospitalisation: an immunomodulatory agent OM-85 BV, or Broncho-Vaxom (Collet 1997), was shown to reduce the number of hospital admissions in COPD, even though it did not affect the number of exacerbations.

Researchers performed a retrospective cost-effectiveness analysis of NAC in chronic bronchitis that was based on direct costs of NAC treatment, management of an acute exacerbation, and indirect costs of sick leave (Grandjean 2000a). Results suggest that costs of treatment and non-treatment were equal at the point of a reduction of 0.6 exacerbations per six-month period. In our review, a reduction of about 0.18 per six-month period suggested that it would not be cost-effective to treat everyone with COPD with mucolytics.

Bachh 2007 and colleagues from India estimated the cost of prophylactic NAC therapy to be INR 6000 (USD 120), whereas a short course of oral corticosteroids (OCSs) and antibiotics would cost INR 200 (USD 4). ICSs are also expensive. As the burden of COPD over coming decades is going to disproportionately affect developing nations, the relative costs of each strategy are important to determine.

Several national and international guidelines make recommendations about the use of mucolytics. In a recent North American guideline on treatments to prevent COPD exacerbations, NAC was suggested for patients with moderate or severe COPD and a history of two or more exacerbations in the previous two years (evidence grade 2B - weak recommendation; moderatequality evidence; Criner 2015). Furthermore, carbocysteine was suggested (ungraded consensus-based statement) for patients still having exacerbations in spite of maximal therapy provided to reduce exacerbations. This is consistent with the more recent 
Joint American Thoracic Society/European Respiratory Society (ATS/ERS) guidelines for prevention of exacerbations, which gives a conditional recommendation for the use of mucolytics in patients with moderate to severe airflow obstruction and frequent exacerbations despite optimal therapy, based on lowquality evidence (Wedzicha 2017). The 2019 update of the global COPD guidelines states that NAC may have a role in the treatment of patients with recurrent exacerbations (evidence grade B - moderate-quality evidence), and that carbocysteine or NAC may reduce exacerbations in patients not taking inhaled steroids (grade B) (GOLD 2019). COPD-X guidelines give a stronger recommendation in favour of high-dose oral NAC (Yang 2018), and UK National Institute for Health and Care Excellence (NICE) guidelines suggest use in patients with chronic cough productive of sputum and continued only if there is symptomatic improvement (NICE 2018).

\section{AUTHORS' CONCLUSIONS}

\section{Implications for practice}

Mucolytics may reduce the number of exacerbations in people with chronic bronchitis or chronic obstructive pulmonary disease (COPD) by a small quantity, and do not appear to be associated with an increase in adverse events. Approximately one person in eight may avoid having an exacerbation, provided all take treatment every day for an average of nine months. Mucolytics are associated with a reduction in days of disability per month and a reduction in hospitalisations in the studies that reported this outcome. Mucolytics have not been shown to substantially slow the decline in lung function, and it is uncertain whether they improve quality of life. Results are too imprecise to be certain whether or not there is an effect on mortality. As reduction in exacerbations seems the main potential benefit, mucolytics might be considered (1) a treatment option for patients with frequent exacerbations who cannot take other therapies such as inhaled corticosteroids or long-acting bronchodilators, which have a stronger evidence base for their effectiveness; or (2) as add-on treatment once all other therapies to reduce exacerbations have been utilised.

\section{Implications for research}

Future studies might address the value of mucolytic therapy:

- in patients who have multiple exacerbations per year, or who have prolonged or severe exacerbations;

- in patients already receiving current guideline-based therapy; and

- in patients with repeated admissions to hospital with exacerbations of COPD despite maximal therapy to reduce acute exacerbations of COPD.

Studies should stratify participants by (1) the new GOLD criteria (AD; GOLD 2019), which incorporate symptoms and exacerbations, as well as spirometry; and (2) use of concomitant medications (such as inhaled corticosteroids (ICSs), long-acting bronchodilators, or macrolide antibiotics).

Outcomes of studies should include hospitalisations (COPD and all-cause), mortality (COPD and all-cause), numbers of days sick with exacerbations, and a validated measure of quality of life. A responder analysis for quality of life would add valuable information on the population effects of treatment.

\section{ACK N O WLEDGEMENTS}

This review is dedicated to the memory of Professor Peter Black, FRACP, who died in 2010. Peter made significant and broad contributions to asthma and COPD research, including work as a reviewer and editor for the Cochrane Airways Group.

We would like to acknowledge the contributions of the following.

- Peter Black, who was the co-author of the first four versions of this review.

- Emma Dennett, Peter Gibson, Paul Jones, and Toby Lasserson of the Cochrane Airways Group for editorial support.

- Emma Jackson, Anna Bara, Karen Blackhall, and Liz Stovold of the Cochrane Airways Group for searching and retrieving fulltext articles.

- Translators Ms. Sharon Kramer, Dr Silvana Campanella, Dr Ruth Black, Dr Klaus Lehnert, Ms. Daniela Screnci, and Mr. Toby Lasserson.

- Professor Marc Decramer, who provided information on SGRQ scores from Decramer 2005.

- Dr Zheng, who gave us more information on Zheng 2008 and Tatsumi 2007a, as well as the appendix to Zheng 2014. For the latter study, Dr Zheng kindly provided further data on exacerbation rate, SGRQ, and spirometry.

- Dompe Farmaceutici (Allegra 1996), which provided us with further data.

- Zambon Group for providing the Meister 1986 study and for further information on Nowak 1999.

- Douglas Pharmaceuticals and G. Pohl Boskamp for information on Meister 1999.

- Professor Roberto Dal Negro, who provided additional information on Dal Negro 2017.

- Dr Dennis Niewoehner, who provided additional information on Johnson 2016.

- Professor Inoue, who provided additional information on Fukuchi 2016.

- Other study authors and companies that took the trouble to write back, even though they could not provide further data ( $\mathrm{Dr}$ Petty, Dr Boman, Novartis Pharmaceuticals).

Sally Spencer was the Editor for this review and commented critically on the review.

The review authors and Cochrane Airways are grateful to the following peer reviewers for their time and comments: Craig P. Hersh, Brigham and Women's Hospital; Prof. Marc Decramer, University Hospital Gasthuisberg, Leuven, Belgium; and our consumer reviewer, Andy Coles, for assessing the plain language summary.

The Background and Methods sections of this review are based on a standard template used by Cochrane Airways.

This project was supported by the National Institute for Health Research (NIHR), via Cochrane Infrastructure funding to the Cochrane Airways Group. The views and opinions expressed therein are those of the authors and do not necessarily reflect those of the Systematic Reviews Programme, NIHR, NHS, or the Department of Health. 


\section{R E F E R E N C E S}

\section{References to studies included in this review}

Allegra 1996 \{published and unpublished data\}

Allegra L, Cordaro $\mathrm{Cl}$, Grassi C. Prevention of acute exacerbations of chronic obstructive bronchitis with carbocysteine lysine salt monohydrate: a multicenter, doubleblind, placebo-controlled trial. Respiration 1996;63:174-80.

Babolini 1980 \{published data only\} Multicenter Study Group. Long-term oral acetylcysteine in chronic bronchitis. A double-blind controlled study. European Journal of Respiratory Disease 1980;61(111 Suppl):93-108.

\section{Bachh 2007 \{published data only\}}

Bachh AA, Shah NN, Bhargava R, Ahmad Z, Pandey DK, Dar KA. Effect of oral $\mathrm{N}$-acetylcysteine in COPD - a randomised controlled trial. JK-Practitioner 2007;14(1):12-6.

\section{Boman 1983 \{published data only\}}

Boman G, Backer U, Larsson S, Melander B, Wahlander L. Oral acetylcysteine reduces exacerbation rate in chronic bronchitis; report of a trial organized by the Swedish Society for Pulmonary Diseases. European Journal of Respiratory Disease 1983;64:405-15.

\section{Bontognali 1991 \{published data only\}}

Bontognali E. Clinical effectiveness and tolerance of cithiolone in the prophylaxis of acute infective exacerbations in patients suffering from chronic bronchitis. Acta Therapeutica 1991;17:155-62.

\section{Borgia 1981 \{published data only\}}

Borgia M, Sepe N, Ori-Belometti M, Borgia R. Comparison between acetylcysteine and placebo in the long term treatment of chronic bronchitis [Confronto tra acetilcisteina e placebo nel trattamento a lungo termine della bronchite cronica]. Gazzetta Medica Italiana 1981;140:467-72.

\section{Castiglioni 1986 \{published data only\}}

Castiglioni CL, Gramolini C. Effect of long-term treatment with sobrerol on the exacerbations of chronic bronchitis. Respiration 1986;50:202-17.

\section{Cegla 1988 \{published data only\}}

Cegla UH. Long-term treatment of chronic bronchitis for two years with ambroxol (Mucosolvan) retard capsules. Results of a double blind trial including 180 patients [Langzeittherapie uber 2 Jahre mit Ambroxol (Mucosolvan) Retardkapseln bei Patienten mit chronischer Bronchitis. Ergebnisse einer Doppelblindstudie an 180 Patienten]. Praxis Klinik der Pneumologie 1988;42:715-21.

\section{Cremonini 1986 \{published data only\}}

Cremonini C, Spada E, Cellini F, Cioni R, Giovannini M, Perri G, et al. I farmaci attivi sul muco nel trattamento di fondo della bronchite cronica [Pharmacotherapy which acts on mucus in long-term treatment of chronic bronchitis]. La Clinica Terapeutica 1986;116:121-9.
Dal Negro 2017 \{published data only\}

Calverley PMA, Page C, Dal Negro RW, Fontana G, Iversen M, Cicero AF, et al. Effect of erdosteine in moderately severe COPD patients. European Respiratory Journal. 2018; Vol. 52:PA776.

Calverley PMA, Page C, Dal Negro RW, Fontana G, Iversen M, Cicero AF, et al. Effect of erdosteine on the rate of COPD exacerbations in spirometrically defined Gold II patients. Respirology. 2017; Vol. 2:49.

Dal Negro RW, Iversen M, Calverly PM. Efficacy and safety of erdostein in COPD: results of a 12-month prospective, multinational study. European Respiratory Journal 2015;46:PA1495.

* Dal Negro RW, Wedzicha JA, Iversen M, Fontana G, Page C, Cicero AF, et al. Effect of erdosteine on the rate and duration of COPD exacerbations: the RESTORE study. European Respiratory Journal 2017;50(4):1700711. [DOI: 10.1183/13993003.00711-2017]

Dal Negro RW, Wedzicha JA, Iversen MI, Fontana G, Page C, Cicero AF, et al. Effect of erdosteine on the rate and duration of COPD exacerbations: the RESTORE study (Reducing Exacerbations and Symptoms by Treatment with ORal Erdosteine). European Respiratory Journal. 2017; Vol. 50:PA675.

De Backer 2013 \{published data only\}

De Backer J, Vos W, Van Holsbeke C, Vinchurkar S, Claes R, Parizel P, et al. Double blind, randomized, two-way crossover, pilot study to assess the effect of high dose $\mathrm{N}$-acetylcysteine on airway geometry, inflammation and oxidative stress in COPD patients using functional respiratory imaging. American Journal of Respiratory and Critical Care Medicine. 2013; Vol. 187, issue A2447.

* De Backer J, Vos W, Van Holsbeke C, Vinchurkar S, Claes R, Parizel PM, et al. Effect of high-dose $\mathrm{N}$-acetylcysteine on airway geometry, inflammation, and oxidative stress in COPD patients. International Journal of Chronic Obstructive Pulmonary Disease 2013;8:569-79.

\section{Decramer 2005 \{published data only\}}

Decramer M, Rutten-van Molken M, Dekhuijzen PN, Troosters T, van Herwaarden C, Pellegrino R, et al. Effects of Nacetylcysteine on outcomes in chronic obstructive pulmonary disease (Bronchitis Randomized on NAC Cost-Utility Study, BRONCUS): a randomised placebo-controlled trial. Lancet 2005;365(9470):1552-60.

\section{Ekberg-Jansson 1999 \{published data only\}}

Ekberg-Jansson A, Larson M, MacNee W, Tunek A, Wahlgren L, Wouters EFM, et al. $\mathrm{N}$ isobutyrylcysteine, a donor of systemic thiols, does not reduce the exacerbation rate in chronic bronchitis. European Respiratory Journal 1999;13(4):829-34.

Fukuchi 2016 \{published data only\}

* Fukuchi Y, Tatsumi K, Inoue H, Sakata Y, Shibata K, Miyagishi $\mathrm{H}$, et al. Prevention of COPD exacerbation by lysozyme: a double-blind, randomized, placebo-controlled 
study. International Journal of Chronic Obstructive Pulmonary Disease 2016;11:831-8.

Ichinose M, Fukuchi Y, Tatsumi K, Inoue H, Arai T, Shibata K, et al. Prevention of COPD exacerbation by lysozyme: a double-blind, randomized, placebo-controlled study. European Respiratory Journal 2015;46:PA4359.

\section{Grassi 1976 \{published data only\}}

Grassi C, Morandini GC. A controlled trial of intermittent oral acetylcysteine in the long-term treatment of chronic bronchitis. European Journal of Clinical Pharmacology 1976;9:393-6.

\section{Grassi 1994 \{published data only\}}

Grassi C, Casali L, Ciaccia A, et al. [Terapia intervallare con l'associazione carbocisteina-sobrerolo nella profilassi delle riacutizzazioni della bronchite cronica]. Italian Journal of Chest Disease 1994;48:17-26.

\section{Grillage 1985 \{published data only\}}

Grillage M, Barnard-Jones K. Long-term oral carbocisteine therapy in patients with chronic bronchitis. A double blind trial with placebo control. British Journal of Clinical Practice 1985;39(10):395-8.

\section{Hansen 1994 \{published data only\}}

Hansen NC, Skriver A, Brorsen-Riis L, Balsløv S, Evald T, Maltbaek N, et al. Orally administered N-acetylcysteine may improve general well-being in patients with mild chronic bronchitis. Respiratory Medicine 1994;88:531-5.

\section{Jackson 1984 \{published data only\}}

Jackson IM, Barnes J, Cooksey P. Efficacy and tolerability of oral acetylcysteine (fabrol) in chronic bronchitis: a doubleblind placebo controlled trial. Journal of International Medical Research 1984;12:198-206.

\section{Johnson 2016 \{published data only\}}

Johnson K, McEvoy CE, Naqvi S, Wendt C, Reilkoff RA, Kunisaki KM, et al. High-dose oral $\mathrm{N}$-acetylcysteine fails to improve respiratory health status in patients with chronic obstructive pulmonary disease and chronic bronchitis: a randomized, placebo-controlled trial. International Journal of Chronic Obstructive Pulmonary Disease 2016;11:799-807.

\section{Malerba 2004 \{published data only\}}

Malerba M, Ponticello A, Radaeli A, Bensi G, Grassi V. Effect of twelve-months therapy with oral ambroxol in preventing exacerbations in patients with COPD. Double-blind, randomized, multi-center, placebo-controlled study (the AMETHIST trial). Pulmonary Pharmacology and Therapeutics 2004;17(1):27-34.

\section{McGavin 1985 \{published data only\}}

British Thoracic Society Research Committee. Oral Nacetylcysteine and exacerbation rates in patients with chronic bronchitis and severe airways obstruction. Thorax 1985;40(11):832-5.

\section{Meister 1986 \{unpublished data only\}}

Meister R. Long-term therapy with acetylcysteine retard tablets in patients with chronic bronchitis: a double-blind, placebo controlled study. Unpublished source 1986.

\section{Meister 1999 \{published data only\}}

Beeh K-M, Beier J, Candler H, Wittig T. Effect of ELOM-080 on exacerbations and symptoms in COPD patients with a chronic bronchitis phenotype - a post-hoc analysis of a randomized, double-blind, placebo-controlled clinical trial. International Journal of Chronic Obstructive Pulmonary Disease 2016;11(1):2877-84.

* Meister R, Wittig T, Beuscher N, de Mey C. Efficacy and tolerability of myrtol standardized in long-term treatment of chronic bronchitis. A double-blind, placebo-controlled study. Study Group Investigators. Arzneimittelforschung 1999;49(4):351-8.

\section{Moretti 2004 \{published data only\}}

* Moretti M, Bottrighi P, Dallari R, Da Porto R, Dolcetti A, Grandi $P$, et al. The effect of long-term treatment with erdosteine on chronic obstructive pulmonary disease: the EQUALIFE study. Drugs Under Experimental and Clinical Research 2004;30(4):143-52.

\section{Nowak 1999 \{published data only\}}

Nowak D, Carati L, Pirozynski M. Long-term administration of $\mathrm{N}$-acetylcysteine reduces the number of acute exacerbation episodes in subjects with chronic obstructive pulmonary disease:report of the BREATHE study. European Respiratory Journal 1999;14 Suppl:381S-2S.

\section{Olivieri 1987 \{published data only\}}

Olivieri D, Zavattini G, Tomasini G, Daniotti S, Bonsignore G, Ferrara G, et al. Ambroxol for the prevention of chronic bronchitis exacerbations: long-term multicenter trial. Respiration 1987;51 Suppl 1:42-51.

\section{Parr 1987 \{published data only\}}

Parr GD, Huitson A. Oral fabrol (oral n-acetyl-cysteine) in chronic bronchitis. British Journal of Diseases of the Chest 1987;81(4):341-8.

\section{Pela 1999 \{published data only\}}

Pela R, Calcagni AM, Subiaco S, Isidori P, Tubaldi A, Sanguinetti CM. N-acetylcysteine reduces the exacerbation rate in patients with moderate to severe COPD. Respiration 1999;66(6):495-500.

\section{Petty 1990 \{published data only\}}

Morgan EJ, Petty TL. Summary of the national mucolytic study. Chest 1990;97(Suppl):24S-7S.

* Petty TL. The national mucolytic study: results of a randomized, double-blind, placebo-controlled study of iodinated glycerol in chronic obstructive bronchitis. Chest 1990;97(1):75-83. 
Rasmussen 1988 \{published data only\}

Rasmussen JB, Glennow C. Reduction in days of illness after long-term treatment with $\mathrm{N}$-acetylcysteine controlled-release tablets in patients with chronic bronchitis. European Respiratory Journal 1988;1:351-5.

\section{Roy 2014 \{published data only\}}

Roy P, Haran A, Srinivas BN. Role of n-acetylcysteine as an adjuvant to mainstay bronchodilator therapy in chronic obstructive pulmonary disease. Indian Journal of Pharmacology Conference Publication 2013;45:S107.

* Roy P, Haran A, Srinivas BN, Mjumdar P. Evaluation of effect of $\mathrm{N}$-acetylcysteine as an adjuvant to mainstay bronchodilator therapy in mild to moderate cases of chronic obstructive pulmonary disease. International Journal of Medical and Applied Sciences 2014;3(1):95-105.

\section{Schermer 2009 \{published data only\}}

Chavannes N, Schermer T, Wouters EFM, Folgering $\mathrm{H}$. Demographic and clinical determinants of response to $\mathrm{N}$ acetylcysteine versus fluticasone in mild to moderate COPD in primary care: the COOPT study. European Respiratory Journal 2005;26 (S49):1356.

* Schermer T, Chavannes N, Dekhuijzen R, Wouters E, Muris J, Akkermans $\mathrm{R}$, et al. Fluticasone and $\mathrm{N}$-acetylcysteine in primary care patients with COPD or chronic bronchitis. Respiratory Medicine 2009;103:542-51.

\section{Tse 2013 \{published data only\}}

Tse HN, Raiteri L, Wong KY, Ng LY, Yee Ks, Tseng CZS. Benefits of high-dose $\mathrm{N}$-acetylcysteine to exacerbation-prone patients with COPD. Chest 2014;146(3):611-23

* Tse HN, Raiteri L, Wong KY, Yee KS, Ng LY, Wai KY, et al. Highdose $\mathrm{N}$-acetylcysteine in stable COPD: the 1-year, doubleblind, randomized, placebo-controlled HIACE study. Chest 2013;144:106-18.

Tse HN, Wong KY, Yee KS, Ng LY. The effect of high dose Nacetylcysteine (1200mg daily) on airway function and airway trapping in COPD patients: a double blinded randomized placebo controlled trial. European Respiratory Journal 2012;40 Suppl 56:P2105.

Tse HN, Wong KY, Yee KS, Ng LY, Wai KY, Loo CK, et al. The effect of high dose $\mathrm{N}$-acetylcysteine (600 mg twice daily) in patients with stable chronic obstructive pulmonary disease - a oneyear, double blind, randomized, placebo-controlled trial. American Journal of Respiratory and Critical Care Medicine 2013;187:A2448.

\section{Worth 2009 \{published data only\}}

* Worth H, Schacher C, Dethlefsen U. Concomitant therapy with cineole (eucalyptole) reduces exacerbations in COPD: a placebo-controlled double-blind trial. Respiratory Research 2009;10(1):69.

Worth H, Schacher C, Dethlefsen U. Effects of concomitant therapy with Cineole (Eucalyptole) on exacerbation rate in COPD: a placebo-controlled double-blind trial. European
Respiratory Society 20th Annual Congress; 2010 Sep 18-22; Barcelona. 2010; Vol. P538.

\section{Xu 2014 \{published data only\}}

Xu X-G, Jiang Z-Y, Du M-J, Yang Y-Q, Jiang Y-C. Evaluation on effectiveness of salmeterol/fluticasone propionate combined with $\mathrm{N}$-acetylcysteine in treatment of chronic obstructive pulmonary disease. [Chinese]. Journal of Jilin University Medicine Edition 2014;40(40):870-4.

\section{Zheng 2008 \{published data only\}}

Zheng JP, Kang J, Huang SG, Chen P, Yao WZ, Yang L, et al. Effect of carbocisteine on acute exacerbations of chronic obstructive pulmonary disease (PEACE study): a randomised placebocontrolled trial. Lancet 2008;371(9629):2013-8.

\section{Zheng 2014 \{published data only\}}

Papi A, Brusselle G, Sergio F, Pannacci M, Zheng J, Criner G. Blood eosinophils and smoking history affect outcome with high dose $\mathrm{N}$-acetylcysteine treatment in COPD. European Respiratory Journal. 2017; Vol. 50:PA1066.

Papi A, Zheng J, Criner GJ, Fabbri LM, Calverley PMA. Impact of smoking status and concomitant medications on the effect of high-dose $\mathrm{N}$-acetylcysteine on chronic obstructive pulmonary disease exacerbations: a post-hoc analysis of the PANTHEON study. Respiratory Medicine 2019;147:37-43.

Sergio F, Papi A, Criner G, Brusselle G, Calverley P, Fabbri L, et al. Long term treatment with $n$-acetylcysteine reduces moderatesevere exacerbations of chronic obstructive pulmonary disease. Respirology 2016;21:186.

Zheng JP, Wen FQ, Bai CX, Wan HY, Kang J, Chen P, et al. Highdose $\mathrm{N}$-acetylcysteine in the prevention of COPD exacerbations: rationale and design of the PANTHEON study. COPD: Journal of Chronic Obstructive Pulmonary Disease 2013;10:164-71.

Zheng JP, Wen FQ, Bai CX, Wan HY, Kang J, Chen P, et al. Highdose $\mathrm{N}$-acetylcysteine in the prevention of COPD exacerbations: results of the PANTHEON study. European Respiratory Society 23rd Annual Congress; 2013 Sep 7-11; Barcelona. 2013.

* Zheng JP, Wen FQ, Bai CX, Wan HY, Kang J, Chen P, et al. Twice daily $\mathrm{N}$-acetylcysteine $600 \mathrm{mg}$ for exacerbations of chronic obstructive pulmonary disease (PANTHEON): a randomised, double-blind placebo-controlled trial. Lancet Respiratory Medicine 2014;2:187-94.

\section{References to studies excluded from this review}

Baglioni 2001 \{published data only\}

Baglioni S, Tazza R, Rossi S, Eslami A, Ferranti P, Dottorini M. Effects of $\mathrm{N}$-acetylcysteine treatment during long term oxygen therapy (LTOT) in COPD patients. An open parallel-group study. European Respiratory Journal 2001;18(33 Suppl):58S.

\section{Cattaneo 2001 \{published data only\}}

Cattaneo C. Neltenexine tablets in smoking and non-smoking patients with COPD. A double-blind, randomised, controlled study versus placebo. Minerva Medica 2001;92(4):277-84. 


\section{Christensen 1971 \{published data only\}}

Andreasen T. Mucolytic treatment of chronic bronchitis during two winter periods. Scandinavian Journal of Respiratory Disease 1974;90:69-70.

Christensen SB, Kjer J, Ryskjaer S, Arseth-Hansen P, Christensen F. Mucolytic treatment of chronic bronchitis during two winter periods. Scandinavian Journal of Respiratory Disease 1971;52(1):48-57.

\section{Edwards 1976 \{published data only\}}

Edwards GF, Steel AE, Scott JK, Jordan JW. Scarboxymethylcysteine in the fluidification of sputum and treatment of chronic airway obstruction. Chest 1976;70(4):506-13.

Habich 1994 \{published data only\}

Habich G, Repges R. Chronic obstructive lung diseases: the efficacy of cineole [Cineol als medikation sinnvoll und bewart]. Therapiewoche 1994;44(6):356-65.

\section{Kasielski 2001 \{published data only\}}

Kasielski M, Nowak D. Long-term administration of Nacetylcysteine decreases hydrogen peroxide exhalation in subjects with chronic obstructive pulmonary disease. Respiratory Medicine 2001;95(6):448-56.

\section{Lukas 2005 \{published data only\}}

Lukas R, Scharling B, Schultze-Werninghaus G, Gillisen A. Administration of $\mathrm{N}$-acetylcysteine and vitamin $\mathrm{C}$ to augment antioxidant properties in patients with chronic bronchitis. Deutsche Medizinishe Wochenscrift 2005;130:563-7.

\section{Maesen 1980 \{published data only\}}

Maesen FP, Brombacher PJ. Treatment of chronic bronchitis with oral acetylcysteine, a double-blind study. European Journal of Respiratory Disease 1980;61:110.

\section{Michnar 1996 \{published data only\}}

Michnar M, Milanowski J. Assessment of efficacy and tolerability of the oral treatment of ambrosol in patients with chronic bronchitis [Ocena kliniczna skutecznosci i tolerancji doustnego leczenia ambrosolem u chorych na przewlekle zapalenie oskrzeli]. Pneumonologia i Alergologia Polska 1996;64(Suppl 1):90-6.

\section{Moretti 2011 \{unpublished data only\}}

Moretti M, Ballabio M. Effect of erdosteine on airflow obstruction and symptom recovery in severe COPD exacerbations [Abstract]. European Respiratory Society 21st Annual Congress; 2011 Sep 24-28; Amsterdam. 2011; Vol. 38 (55):76s [P536].

\section{Moretti 2014 \{published data only\}}

Moretti M. Erdosteine oral treatment of hospitalised COPD exacerbation prolongs time to first re-exacerbation [Abstract]. European Respiratory Journal 2014;44:P293.

Pirabbasi 2016 \{published data only\}

* Pirabbasi E, Shahar S, Manaf ZA, Rajab NF, Manap RA.

Efficacy of ascorbic acid (vitamin C) and/N-acetylcysteine (NAC) supplementation on nutritional and antioxidant status of male chronic obstructive pulmonary disease (COPD) patients. Journal of Nutritional Science and Vitaminology 2016;62(1):54-61.

Rubin 1996 \{published data only\}

Rubin BK, Ramirez O, Ohar JA. lodinated glycerol has no effect on pulmonary function, symptom score, or sputum properties in patients with stable chronic bronchitis. Chest 1996;109(2):348-52.

Saibene 2016 \{published data only\}

Saibene F, Paone G, Lanata L, Puglisi G, Moscatelli B, Colli RD. Effect of carbocysteine lysine salt on frequency of exacerbations in COPD patient treated with or without inhaled steroids. European Respiratory Journal 2016;48:PA544.

Salve 2016 \{published data only\}

Salve VT, Atram JS. N-Acetylcysteine combined with home based physical activity: effect on health related quality of life in stable COPD patients - a randomised controlled trial. Journal of Clinical and Diagnostic Research 2016;10(12):OC16-OC19.

Sushko 2015 \{published data only\}

Sushko V, Shvaiko L, Bazyka K, Riazhska A. Treatment of chronic obstructive pulmonary disease in clean-up workers of the Chornobyl NPP accident in the remote period after irradiation with additional 6 month prescription combination of ambroxol and essential phospholipids. European Respiratory Journal 2016;48:PA4299.

Sushko VO, Shvaiko LI, Bazyka KD, Riazhska AS. Optimization of chronic obstructive pulmonary disease treatment in cleanup workers of the Chornobyl NPP accident in the remote period after irradiation. Problemy Radiatsiinoi Medytsyny Ta Radiobiolohii 2015;20:457-66.

Tatsumi 2007a \{published data only\}

Tatsumi K, Fukuchi Y. Carbocisteine improves quality of life in patients with chronic obstructive pulmonary disease. Journal of the American Geriatrics Society 2007;55(11):1884-5.

Tatsumi 2007b \{published data only\}

Tatsumi K, Fukuchi Y. Carbocisteine reduces the frequency of exacerbations in patients with COPD: findings from the PEACE study. American Thoracic Society International Conference; 2007; May 18-23; San Francisco. 2007:C97.

\section{Velazquez 2001 \{published data only\}}

Velazquez A, Aguilar G, Sanchez C, Ochoa L, Sansores R, Remirez-Venegas A. The mucolytic effect on quality of life in patients with COPD. American Journal of Respiratory and Critical Care Medicine 2001;163(5 Suppl):A57.

\section{Wilhelmi 2010 \{published data only\}}

Wilhelmi E. Treatment of COPD: benefit of 1.8 cineole as co medication confirmed [Behandlung der COPD: nutzen voan 1.8cineol als zusatztherapie bestatigt]. Journal Pharmakol U Ther 2010;2:554-5. 


\section{References to studies awaiting assessment}

CTRI/2015/01/005432 \{published data only\}

Hussain A, Rizvi W. Comparative Evaluation of Efficacy and Safety Profile of Antioxidants-N-Acetyl-L-Cysteine(NAC) and Superoxide Dismutase (SOD) Supplementation in Patients of COPD. Clinical Trials Registry - India 2015.

\section{References to ongoing studies}

ChiCTR1800016712 \{published data only\}

Early Intervention With Carbocysteine and Low Dose Theophylline in Chinese Patients With Chronic Obstructive Pulmonary Disease. Chinese Clinical Trials Registry 2018. [ChiCTR1800016712]

\section{ChiCTR-IIR-17012604 \{published data only\}}

Zhou Y, Ran P. Long-Term Regular Treatment of Early COPD With Randomized, Double-Blind, Placebo-Controlled Multicenter Clinical Study With Acetylcysteine Effervescent Tablets. Chinese Clinical Trial Registry 2017. [ChiCTR-IIR-17012604]

\section{Additional references}

\section{Anzueto 1997}

Anzueto A, Jubran A, Ohar JA, Piquette CA, Rennard SI, Colice G. Effects of aerosolized surfactant in patients with stable chronic bronchitis: a prospective randomized controlled trial. Journal of American Medical Association 1997;278(17):1426-31.

\section{Ballabio 2008}

Ballabio M, Nicola M, Moretti M. Long-term use of antioxidant mucolytic erdosteine is especially beneficial in patient with more severe COPD. European Respiratory Society 18th Annual Congress; 2008 Oct 3-7; Berlin. 2008:abstract ERS08L1_678.

\section{Cates 2002}

Cates CJ. Simpson's paradox and calculation of number needed to treat from meta-analysis. BMC Medical Research Methodology 2002;2:1. [DOI: 10.1186/1471-2288-2-1]

\section{Cazzola 2015}

Cazzola M, Calzetta L, Page C, Jardim J, Chuchalin AG, Rogliani $\mathrm{P}$, et al. Influence of $\mathrm{N}$-acetylcysteine on chronic bronchitis or COPD exacerbations: a meta-analysis. European Respiratory Review 2015;24(137):451-61.

\section{Collet 1997}

Collet JP, Shapiro P, Ernst P, Renzi T, Ducruet T, Robinson A. Effects of an immunostimulating agent on acute exacerbations and hospitalizations in patients with chronic obstructive pulmonary disease. American Journal of Respiratory and Critical Care Medicine 1997;156(6):1719-24.

\section{Criner 2015}

Criner GJ, Bourbeau J, Diekemper RL, Ouellette DR, Goodridge D, Hernandez P, et al. Prevention of acute exacerbation of COPD: American College of Chest Physicians and Canadian Thoracic Society Guideline. Chest 2015;147(4):883-93.

\section{Fowdar 2017}

Fowdar K, Chen H, He Z, Zhang J, Zhong X, Zhang J, et al. The effect of $\mathrm{N}$-acetylcysteine on exacerbations of chronic obstructive pulmonary disease: a meta-analysis and systematic review. Heart and Lung 2017;46(2):120-8.

\section{GOLD 2019}

Global Strategy for the Diagnosis, Management and Prevention of COPD, Global Initiative for Chronic Obstructive Lung Disease (GOLD) 2019. goldcopd.org/wp-content/uploads/2018/11/ GOLD-2019-v1.7-FINAL-14Nov2018-WMS.pdf (accessed before 14 December 2018).

\section{Grandjean 2000}

Grandjean EM, Berthet PH, Ruffman R, Leuenberger PH. Efficacy of oral long-term $\mathrm{N}$-acetylcysteine in chronic bronchopulmonary disease: a meta-analysis of published double-blind, placebo-controlled clinical trials. Clinical Therapeutics 2000;22(2):209-20.

\section{Grandjean 2000a}

Grandjean EM, Berthet PH, Ruffman R, Leuenberger PH. Costeffectiveness analysis of oral $\mathrm{N}$-acetylcysteine as a preventive treatment in chronic bronchitis. Pharmacology Research 2000;42(1):39-50.

\section{Guyatt 1987}

Guyatt GH, Berman LB, Townsend M, Pugsley SO, Chambers LW. A measure of quality of life for clinical trials in chronic lung disease. Thorax 1987;42(10):773-88.

\section{Higgins 2011}

Higgins JPT, Green S (editors). Cochrane Handbook for Systematic Reviews of Interventions Version 5.1.0 (updated March 2011). The Cochrane Collaboration, 2011. [Available from www.handbook.cochrane.org]

\section{Jones 1992}

Jones PW, Quirk FH, Baveystock CM, Littlejohns P. A selfcomplete measure of health status for chronic airflow limitation: the St. George's Respiratory Questionnaire. American Review of Respiratory Disease 1992;145(6):1321-7.

\section{Jones 2005}

Jones PW. St. George's Respiratory Questionnaire: MCID. COPD 2005;2(1):75-9.

\section{Jones 2013}

Jones PW, Beeh KM, Chapman KR, Decramer M, Mahler DA, Wedzicha JA. Minimal clinically important differences in pharmacological trials. American Journal of Respiratory and Critical Care Medicine 2013;189(3):250-5.

\section{Li 2015}

Li X, Sun H, Liu C, Kang J. Mucolytic and antioxidant agents for exacerbations of chronic obstructive pulmonary disease: a meta-analysis. Chinese Journal of Tuberculosis and Respiratory Diseases 2015;38(8):600-6. 


\section{Moretti 2007}

Moretti M, Nicola M. Prevention of COPD exacerbations and reduction of health care utilization with erdosteine. European Respiratory Journal 2007;30(Suppl 51):557s.

\section{NICE 2018}

National Institute for Health and Care Excellence. Chronic obstructive pulmonary disease in over 16s: diagnosis and management. www.nice.org.uk/guidance/ng115 (accessed before 14 December 2018).

\section{Qaseem 2011}

Qaseem A, Wilt TJ, Weinberger SE, Hanania NA, Criner G, van der Molen T, et al. Diagnosis and management of stable chronic obstructive pulmonary disease: a clinical practice guideline update from the American College of Physicians, American College of Chest Physicians, American Thoracic Society, and European Respiratory Society. Annals of Internal Medicine 2011;155(3):179-91.

\section{Rahman 2005}

Rahman I. Oxidative stress in the pathogenesis of chronic obstructive pulmonary disease; cellular and molecular mechanisms. Cell Biochemistry and Biophysics 2005;43(1):167-88.

\section{Rennard 2006}

Rennard SI, Vestbo J. COPD: the dangerous underestimate of 15\%. Lancet 2006;367(9518):1216-9.

Rubin 2007

Rubin BK. Mucolytics, expectorants, and mucokinetic medications. Respiratory Care 2007;52:859-65.

\section{Rubin 2014}

Rubin BK. Secretion properties, clearance, and therapy in airway disease. Translational Respiratory Medicine 2014;2:6.

\section{Stey 2000}

Stey C, Steurer J, Bachmann S, Medici TC, Tramer MR. The effect of oral $\mathrm{N}$-acetylcysteine in chronic bronchitis: a quantitative systematic review. European Respiratory Journal 2000;16(2):253-62.

\section{van Agteren 2016}

van Agteren JEM, Carson KV, Tiong LU, Smith BJ. Lung volume reduction surgery for diffuse emphysema. Cochrane Database of Systematic Reviews 2016, Issue 10. [DOI: 10.1002/14651858.CD001001.pub3]

\section{Wedzicha 2017}

Wedzicha JA, Calverley PMA, Albert RK, Anzueto A, Criner GJ, Hurst JR, et al. Prevention of COPD exacerbations: a European
Respiratory Society/American Thoracic Society guideline. European Respiratory Journal 2017;50(3):pii: 1602265.

\section{WHO 2017}

World Health Organization. The top 10 causes of death. www.who.int/mediacentre/factsheets/fs310/en/ (accessed before 14 December 2018).

\section{Yang 2018}

Yang IA, Brown JL, George J, Jenkins S, McDonald CF, McDonald V, et al. The COPD-X Plan: Australian and New Zealand Guidelines for the Management of Chronic Obstructive Pulmonary Disease. Version 2.53. copdx.org.au/wp-content/ uploads/2018/11/COPDX-V2-55-Aug-2018.pdf (accessed before 13 December 2018).

\section{References to other published versions of this review Poole 1998}

Poole PJ, Black PN. The effect of mucolytic agents on exacerbation frequency in chronic bronchitis. Cochrane Database of Systematic Reviews 1998, Issue 4. [DOI: 10.1002/14651858.CD001287]

\section{Poole 1999}

Poole PJ, Black PN. Mucolytic agents for chronic bronchitis. Cochrane Database of Systematic Reviews 1999, Issue 2. [DOI: 10.1002/14651858.CD001287]

\section{Poole 2001}

Poole PJ, Black PN. Oral mucolytic drugs for exacerbations of chronic obstructive pulmonary disease: systematic review. BMJ 2001;322:1271-4.

\section{Poole 2006}

Poole PJ, Black PN. Mucolytic agents for chronic bronchitis or chronic obstructive pulmonary disease. Cochrane Database of Systematic Reviews 2006, Issue 3. [DOI: 10.1002/14651858.CD001287.pub2]

\section{Poole 2012}

Poole PJ, Black PN, Cates CJ. Mucolytic agents for chronic bronchitis or chronic obstructive pulmonary disease. Cochrane Database of Systematic Reviews 2012, Issue 8. [DOI: 10.1002/14651858.CD001287]

\section{Poole 2015}

Poole P, Chong J, Cates CJ. Mucolytic agents versus placebo for chronic bronchitis or chronic obstructive pulmonary disease. Cochrane Database of Systematic Reviews 2015, Issue 7. [DOI: 10.1002/14651858.CD001287.pub5]

* Indicates the major publication for the study

\section{CHARACTERISTICS OF STUDIES}

Characteristics of included studies [ordered by study ID] 
Allegra 1996

Methods

Randomised, double-blind, placebo-controlled, parallel, multi-centre study, with 1 month run-in before randomisation. Duration 6 months. ITT and PP analysis

\section{Participants}

440 participants with chronic bronchitis (MRC). Age 20 to $70 ; \mathrm{FEV}_{1} 40 \%$ to $70 \%$; at least 2 exacerbations in previous 12 months

Exclusions: neoplastic disease, TB, asthma or uncompensated liver, kidney or heart disease, pregnancy

Other mucoactive and anti-cough agents, oral or inhaled corticosteroids not permitted

Mean age 60 years; 75\% had smoking history; FEV 12.12 (SD 0.6) L; mean 2.7 (SD 1.3) exacerbations in past 12 months

Dropouts: $89(20 \%)$

\begin{tabular}{ll}
\hline Interventions & $\begin{array}{l}3 \text { treatment arms. Carbocysteine lysine salt monohydrate (SCMC-Lys) } 2.7 \mathrm{~g} \text { daily, placebo, and SCMC- } \\
\text { Lys } 2.7 \mathrm{~g} \text { daily alternating } 1 \text { week active, } 1 \text { week placebo. We assessed continuous vs placebo treatment } \\
\text { only }\end{array}$ \\
\hline Outcomes & $\begin{array}{l}\text { Diary scores of symptoms, exacerbations, time to first exacerbation, duration of exacerbation, days on } \\
\text { antibiotics, adverse events }\end{array}$ \\
\hline Notes & $\begin{array}{l}\text { Italian. Requested SD for exacerbations for per-protocol and intention-to-treat analysis. Requested da- } \\
\text { ta were provided by sponsoring company. ITT analysis was done with an estimate of duration of treat- } \\
\text { ment derived from the paper }\end{array}$
\end{tabular}

\section{Risk of bias}

\begin{tabular}{lll}
\hline Bias & Authors' judgement & Support for judgement \\
\hline $\begin{array}{l}\text { Random sequence genera- } \\
\text { tion (selection bias) }\end{array}$ & Low risk & Computer-generated; balanced per centre \\
\hline $\begin{array}{l}\text { Allocation concealment } \\
\text { (selection bias) }\end{array}$ & Unclear risk & Information not available \\
\hline $\begin{array}{l}\text { Blinding of participants } \\
\text { and personnel (perfor- } \\
\text { mance bias) }\end{array}$ & Low risk & Double-blind; matching placebo \\
$\begin{array}{l}\text { All outcomes } \\
\text { Blinding of outcome as- } \\
\text { sessment (detection bias) }\end{array}$ & Low risk & \\
$\begin{array}{l}\text { All outcomes } \\
\begin{array}{l}\text { Incomplete outcome data } \\
\text { (attrition bias) } \\
\text { All outcomes }\end{array}\end{array}$ & High risk & Double-blind \\
\hline $\begin{array}{l}\text { Selective reporting (re- } \\
\text { porting bias) }\end{array}$ & Low risk & $\begin{array}{l}\text { 20\% dropout rate (89/440); dropout was higher in the intervention arm com- } \\
\text { pared to the placebo arm (23\% vs 16\%), largely due to more participants in the } \\
\text { intervention arm failing to comply with the trial protocol }\end{array}$ \\
\hline
\end{tabular}

Babolini 1980

\begin{tabular}{ll}
\hline Methods & Double-blind, placebo-controlled, parallel, 36 centres. PP analysis. Duration 6 months \\
\hline Participants & $\begin{array}{l}744 \text { outpatients with chronic bronchitis defined by MRC. Excluded if too young, too sick, additional sig- } \\
\text { nificant disease, history of peptic ulcer, on mucolytics. } 60 \% \text { were over the age of } 50 ; 73.5 \% \text { were male; }\end{array}$
\end{tabular}


Babolini 1980 (Continued)

mean FEV 2.18 L; FEV $140 \%$ to $70 \%$ predicted; $64.3 \%$ smokers. 249 dropouts. Baseline groups matched. Dropout groups matched

\begin{tabular}{|c|c|c|}
\hline Interventions & \multicolumn{2}{|c|}{ NAC 200 mg twice daily or placebo } \\
\hline Outcomes & \multicolumn{2}{|c|}{$\begin{array}{l}\text { Exacerbations, symptom scores, global assessments by participants and physicians, adverse effects, } \\
\text { days on antibiotics }\end{array}$} \\
\hline Notes & \multicolumn{2}{|c|}{$\begin{array}{l}\text { Italian. Same data also in Ferrari. SD calculated from graph. } 5 \text { or more exacerbations counted as } 5 \text {. Fur- } \\
\text { ther data requested but not yet provided }\end{array}$} \\
\hline \multicolumn{3}{|l|}{ Risk of bias } \\
\hline Bias & Authors' judgement & Support for judgement \\
\hline $\begin{array}{l}\text { Random sequence genera- } \\
\text { tion (selection bias) }\end{array}$ & Unclear risk & 'Restricted' randomisation; balanced blocks \\
\hline $\begin{array}{l}\text { Allocation concealment } \\
\text { (selection bias) }\end{array}$ & Unclear risk & Information not available \\
\hline $\begin{array}{l}\text { Blinding of participants } \\
\text { and personnel (perfor- } \\
\text { mance bias) } \\
\text { All outcomes }\end{array}$ & Low risk & Double-blind; matching placebo, identified by code number \\
\hline $\begin{array}{l}\text { Blinding of outcome as- } \\
\text { sessment (detection bias) } \\
\text { All outcomes }\end{array}$ & Low risk & Double-blind \\
\hline $\begin{array}{l}\text { Incomplete outcome data } \\
\text { (attrition bias) } \\
\text { All outcomes }\end{array}$ & High risk & $\begin{array}{l}\text { 117/371 (32\%) participants dropped out of the intervention arm and } 132 / 373 \\
(35 \%) \text { participants dropped out of the placebo arm. More participants with- } \\
\text { drew from the placebo arm due to lack of efficacy ( } 6 \text { vs } 2 \text { ) and adverse reac- } \\
\text { tions ( } 13 \text { vs } 6) \text {; other reasons were reasonably balanced }\end{array}$ \\
\hline $\begin{array}{l}\text { Selective reporting (re- } \\
\text { porting bias) }\end{array}$ & Low risk & None detected \\
\hline
\end{tabular}

\section{Bachh 2007}

Methods Randomised, single-blind, placebo-controlled, parallel, single-centre. Follow-up 12 months, although
treatment given for only 4 months

\section{Participants}

100 outpatients with smoking-related COPD. Age $>50$ years; post-bronchodilator $\mathrm{FEV}_{1} 30 \%$ to $80 \%$ predicted; reversibility $<12 \% ; \mathrm{FEV}_{1} / \mathrm{FVC}<70 \%$. Stable medications and ICS permitted at steady dose Exclusions: intolerance of NAC, continuous treatment with OCS, NAC for 3/12 or more, asthma or atopy, other respiratory diseases, NYHA Class II or greater heart failure. Non-compliance in taking medication

Mean age: 61 (SD 7) years; $78 \%$ male. Mean duration of disease 6.4 years. Mean number of exacerbations in 2 years before study, 4.7. Mean $\mathrm{FEV}_{1} 52 \%$ (SD 10) predicted and reversibility $6 \%$ (SD3). 18/100 $(18 \%)$ were using ICS

No dropouts recorded

Interventions NAC 600 mg once daily or placebo for 4 months


Bachh 2007 (Continued)

Outcomes Exacerbations, hospital admissions, pulmonary function tests, adverse effects

Notes Indian study

Risk of bias

\begin{tabular}{|c|c|c|}
\hline Bias & Authors' judgement & Support for judgement \\
\hline $\begin{array}{l}\text { Random sequence genera- } \\
\text { tion (selection bias) }\end{array}$ & Unclear risk & Information not available \\
\hline $\begin{array}{l}\text { Allocation concealment } \\
\text { (selection bias) }\end{array}$ & High risk & Single-blind \\
\hline $\begin{array}{l}\text { Blinding of participants } \\
\text { and personnel (perfor- } \\
\text { mance bias) } \\
\text { All outcomes }\end{array}$ & High risk & Single-blind; investigators not blinded \\
\hline $\begin{array}{l}\text { Blinding of outcome as- } \\
\text { sessment (detection bias) } \\
\text { All outcomes }\end{array}$ & High risk & Single-blind \\
\hline $\begin{array}{l}\text { Incomplete outcome data } \\
\text { (attrition bias) } \\
\text { All outcomes }\end{array}$ & Low risk & No dropouts recorded \\
\hline $\begin{array}{l}\text { Selective reporting (re- } \\
\text { porting bias) }\end{array}$ & Low risk & Main outcomes reported \\
\hline
\end{tabular}

Boman 1983

\begin{tabular}{ll}
\hline Methods & Randomised, double-blind, placebo-controlled, parallel, run-in, multi-centre. Duration 6 months \\
\hline Participants & $\begin{array}{l}259 \text { outpatients with chronic bronchitis defined by MRC. Exclusion criteria: asthma, FEV }<\text { < 50\%; oth- } \\
\text { er comorbidities; on antibiotics; women pregnant or trying for pregnancy. } 56 \text { dropouts. Mean age } 51.9 \\
\text { years. FEV } 80 \% \text { predicted. } 100 \% \text { smokers Exacerbations in past } 12 \text { months }\end{array}$ \\
\hline Interventions & NAC $200 \mathrm{mg}$ twice daily or placebo \\
\hline Outcomes & Exacerbations, sick leave due to exacerbations, adverse effects \\
\hline Notes & $\begin{array}{l}\text { Swedish. SD calculated from paper. } 6 \text { or more exacerbations counted as } 6 . \text { Requested more informa- } \\
\text { tion to calculate effect on sick days, but study authors unable to locate original material }\end{array}$ \\
\hline
\end{tabular}

\section{Risk of bias}

\begin{tabular}{lll}
\hline Bias & Authors' judgement & Support for judgement \\
\hline $\begin{array}{l}\text { Random sequence genera- } \\
\text { tion (selection bias) }\end{array}$ & High risk & Done independently at each centre via a table of random numbers \\
\hline $\begin{array}{l}\text { Allocation concealment } \\
\text { (selection bias) }\end{array}$ & High risk & Investigators aware of order of allocation \\
\hline
\end{tabular}


Boman 1983 (Continued)

Blinding of participants Unclear risk Double-blind, but may have been aware of allocation and personnel (perfor-

mance bias)

All outcomes

\begin{tabular}{|c|c|c|}
\hline $\begin{array}{l}\text { Blinding of outcome as- } \\
\text { sessment (detection bias) } \\
\text { All outcomes }\end{array}$ & Unclear risk & Double-blind, but may have been aware of allocation \\
\hline $\begin{array}{l}\text { Incomplete outcome data } \\
\text { (attrition bias) } \\
\text { All outcomes }\end{array}$ & Unclear risk & $\begin{array}{l}\text { High dropout rate }(22 \% ; 56 / 259) \text {, but numbers and reasons similar in both trial } \\
\text { arms. All participants included in the safety analyses }\end{array}$ \\
\hline $\begin{array}{l}\text { Selective reporting (re- } \\
\text { porting bias) }\end{array}$ & Low risk & Main outcomes reported \\
\hline
\end{tabular}

\section{Bontognali 1991}

\begin{tabular}{ll}
\hline Methods & Randomised, double-blind, placebo-controlled. Duration 3 months \\
\hline Participants & $\begin{array}{l}60 \text { participants with chronic bronchitis recruited as inpatients; } 63 \% \text { male. Mean age } 57 \text { years. Admis- } \\
\text { sion criteria } 20 \mathrm{~mL} \text { sputum/day with history of } 4 \text { or more episodes of acute bronchitis in past } 12 \text { months } \\
\text { and Tiffeneau index } \leq 40 \% \text {. No loss to follow-up }\end{array}$ \\
\hline Interventions & $\begin{array}{l}\text { Cithiolone } 400 \mathrm{mg} \text { twice daily or placebo for } 1 \text { month followed by } 400 \text { mg once daily for a further } 2 \\
\text { months }\end{array}$ \\
\hline Outcomes & Exacerbations and duration of acute exacerbations, FEV ${ }_{1}$ and FVC, sputum viscosity, adverse effects \\
\hline Notes & $\begin{array}{l}\text { Italian. Surprising that no participants withdrew from the study. Huge confidence limits. Possible typo- } \\
\text { graphical error in paper, as SD for number of exacerbations per month is the same as for duration of ex- } \\
\text { acerbations. We have used study authors' rates in comparison 01:02 and divided them by months }\end{array}$
\end{tabular}

\section{Risk of bias}

\begin{tabular}{lll}
\hline Bias & Authors' judgement & Support for judgement \\
\hline $\begin{array}{l}\text { Random sequence genera- } \\
\text { tion (selection bias) }\end{array}$ & Unclear risk & Information not available \\
\hline $\begin{array}{l}\text { Allocation concealment } \\
\text { (selection bias) }\end{array}$ & Unclear risk & Information not available \\
\hline $\begin{array}{l}\text { Blinding of participants } \\
\text { and personnel (perfor- } \\
\text { mance bias) } \\
\text { All outcomes }\end{array}$ & Low risk & Double-blind \\
\hline $\begin{array}{l}\text { Blinding of outcome as- } \\
\text { sessment (detection bias) } \\
\text { All outcomes }\end{array}$ & Low risk & Double-blind \\
\hline $\begin{array}{l}\text { Incomplete outcome data } \\
\text { (attrition bias) } \\
\text { All outcomes }\end{array}$ & Low risk & \\
\hline
\end{tabular}


Bontognali 1991 (Continued)

Selective reporting (re- Unclear risk Main outcomes not stated viz "efficacy" porting bias)

Borgia 1981

\begin{tabular}{ll}
\hline Methods & Randomised, double-blind, placebo-controlled, parallel, multi-centre. PP analysis. Duration 6 months \\
\hline Participants & $\begin{array}{l}21 \text { outpatients with chronic bronchitis defined by MRC and exacerbation in period before the study. } \\
\text { Mean age } 45.3 \text { years and FEV } 3.82 \mathrm{~L}^{2} \text { Exclusions not stated except } \mathrm{FEV}_{1}<40 \% .2 \mathrm{dropped} \text { out }\end{array}$ \\
\hline Interventions & NAC $200 \mathrm{mg}$ twice daily or placebo \\
\hline Outcomes & Exacerbations, lung function, symptom scores, clinical assessment, adverse effects \\
\hline Notes & $\begin{array}{l}\text { Italian. Published in Italian; therefore reliant on translation. Large differences in baseline rates for lung } \\
\text { function }\end{array}$
\end{tabular}

\section{Risk of bias}

\begin{tabular}{|c|c|c|}
\hline Bias & Authors' judgement & Support for judgement \\
\hline $\begin{array}{l}\text { Random sequence genera- } \\
\text { tion (selection bias) }\end{array}$ & Unclear risk & Information not available \\
\hline $\begin{array}{l}\text { Allocation concealment } \\
\text { (selection bias) }\end{array}$ & Unclear risk & Information not available \\
\hline $\begin{array}{l}\text { Blinding of participants } \\
\text { and personnel (perfor- } \\
\text { mance bias) } \\
\text { All outcomes }\end{array}$ & Low risk & Double-blind \\
\hline $\begin{array}{l}\text { Blinding of outcome as- } \\
\text { sessment (detection bias) } \\
\text { All outcomes }\end{array}$ & Low risk & Double-blind \\
\hline $\begin{array}{l}\text { Incomplete outcome data } \\
\text { (attrition bias) } \\
\text { All outcomes }\end{array}$ & Unclear risk & $\begin{array}{l}9 \% \text { dropout rate }(2 / 21) \text {, both from the placebo arm. One participant failed to } \\
\text { return for follow-up and the other experienced diarrhoea }\end{array}$ \\
\hline $\begin{array}{l}\text { Selective reporting (re- } \\
\text { porting bias) }\end{array}$ & Low risk & Main outcomes reported \\
\hline
\end{tabular}

Castiglioni 1986

Methods Randomised, double-blind, placebo-controlled, parallel, multi-centre (18). PP analysis. Duration 3 months

Participants

706 outpatients with chronic bronchitis defined by MRC. Mean age 56.5 years; $76 \%$ male; FEV $73.3 \%$ predicted; $73.5 \%$ current or former smokers. Excluded were patients younger than 18 years or older than 75 ; $\mathrm{FEV}_{1}<60 \%$; severe comorbidity; prior treatment with oral corticosteroids or antibiotics and $>2$ other medications. 33 dropped out 
Castiglioni 1986 (Continued)

Interventions Sobrerol $300 \mathrm{mg}$ twice daily or placebo

Outcomes Exacerbation rate, consumption of antibiotics and other medicines, clinical signs, laboratory data, lung function, global assessment by investigator and participant, adverse effects

Notes Italian. Requested more information to allow determination of days on antibiotics; not yet provided

\section{Risk of bias}

\begin{tabular}{|c|c|c|}
\hline Bias & Authors' judgement & Support for judgement \\
\hline $\begin{array}{l}\text { Random sequence genera- } \\
\text { tion (selection bias) }\end{array}$ & High risk & $\begin{array}{l}\text { Done independently at each centre with a table of random numbers to obtain } \\
\text { balanced groups }\end{array}$ \\
\hline $\begin{array}{l}\text { Allocation concealment } \\
\text { (selection bias) }\end{array}$ & High risk & Investigators aware of order of allocation \\
\hline $\begin{array}{l}\text { Blinding of participants } \\
\text { and personnel (perfor- } \\
\text { mance bias) } \\
\text { All outcomes }\end{array}$ & Unclear risk & Double-blind; matching placebo but may have been aware of allocation \\
\hline $\begin{array}{l}\text { Blinding of outcome as- } \\
\text { sessment (detection bias) } \\
\text { All outcomes }\end{array}$ & Unclear risk & Double-blind but may have been aware of allocation \\
\hline $\begin{array}{l}\text { Incomplete outcome data } \\
\text { (attrition bias) } \\
\text { All outcomes }\end{array}$ & Low risk & $5 \%$ dropout rate (33/706); numbers and reasons balanced between trial arms \\
\hline $\begin{array}{l}\text { Selective reporting (re- } \\
\text { porting bias) }\end{array}$ & Low risk & Main outcomes reported \\
\hline
\end{tabular}

\section{Cegla 1988}

Methods Randomised, double-blind, placebo-controlled, parallel, multi-centre. PP analysis. Duration 24 months

Participants 180 outpatients with chronic bronchitis defined by WHO

Mean age 51.1 years; $64 \%$ male. Mean FEV 12.15 L; 36\% current smokers. Excluded were patients over

60 years of age and patients with asthma, cor pulmonale, pulmonary hypertension, or polycythaemia < $60 \% .23$ dropped out. 4 people died

\begin{tabular}{ll}
\hline Interventions & Ambroxol retard $75 \mathrm{mg}$ daily or placebo \\
\hline Outcomes & $\begin{array}{l}\text { Exacerbations, days sick (off work, in hospital), participant symptoms by diary card, lung function, ex- } \\
\text { tra medication use, assessment by investigator and participant, adverse effects }\end{array}$
\end{tabular}

Notes German. Written in German. Required translation

\section{Risk of bias}

\begin{tabular}{lll}
\hline Bias & Authors' judgement & Support for judgement \\
\hline $\begin{array}{l}\text { Random sequence genera- } \\
\text { tion (selection bias) }\end{array}$ & Unclear risk & Information not available \\
\hline
\end{tabular}


Cegla 1988 (Continued)

\begin{tabular}{lll}
$\begin{array}{l}\text { Allocation concealment } \\
\text { (selection bias) }\end{array}$ & Unclear risk & Information not available \\
\hline $\begin{array}{l}\text { Blinding of participants } \\
\text { and personnel (perfor- } \\
\text { mance bias) } \\
\text { All outcomes }\end{array}$ & Low risk & Double-blind \\
\hline $\begin{array}{l}\text { Blinding of outcome as- } \\
\text { sessment (detection bias) } \\
\text { All outcomes }\end{array}$ & Low risk & Double-blind \\
\hline $\begin{array}{l}\text { Incomplete outcome data } \\
\text { (attrition bias) }\end{array}$ & Unclear risk & \\
All outcomes & & $\begin{array}{l}\text { A total of } 23 / 180 \text { (13\%) participants did not complete follow-up. } 7 / 180 \text { partic- } \\
\text { ipants were excluded from the final analysis (4 in the intervention group and } \\
3 \text { in the placebo group). } \text { A further } 16 \text { participants were followed up for at least } \\
6 \text { months but dropped out before completing the trial. Reasons for loss to fol- } \\
\text { low-up are not given }\end{array}$
\end{tabular}

$\begin{array}{lll}\text { Selective reporting (re- Unclear risk } & \text { Information not available } \\ \text { porting bias) }\end{array}$
porting bias)

\section{Cremonini 1986}

\begin{tabular}{ll}
\hline Methods & Randomised, double-blind, placebo-controlled, parallel. Duration 3 months \\
\hline Participants & $\begin{array}{l}41 \text { outpatients with chronic bronchitis defined by ERS, all of whom completed the study. Exclusion cri- } \\
\text { teria not stated. Mean age } 60.8 \text { years; } F_{1}, 58.6 \% \text { predicted }\end{array}$ \\
\hline Interventions & Letosteine $50 \mathrm{mg} 3$ times daily or placebo \\
\hline Outcomes & Exacerbations, days off work sick, lung function. Adverse effects not evaluated \\
\hline Notes & $\begin{array}{l}\text { Italian. Written in Italian; therefore relying on translation. SD calculated from raw data in paper, but } \\
\text { numbers in placebo and active groups vary (20/21 or } 21 / 20 \text { respectively) }\end{array}$ \\
\hline
\end{tabular}

\section{Risk of bias}

\begin{tabular}{lll}
\hline Bias & Authors' judgement & Support for judgement \\
\hline $\begin{array}{l}\text { Random sequence genera- } \\
\text { tion (selection bias) }\end{array}$ & Unclear risk & Information not available \\
\hline $\begin{array}{l}\text { Allocation concealment } \\
\text { (selection bias) }\end{array}$ & Unclear risk & Information not available \\
\hline $\begin{array}{l}\text { Blinding of participants } \\
\text { and personnel (perfor- } \\
\text { mance bias) }\end{array}$ & Low risk & Double-blind \\
$\begin{array}{l}\text { All outcomes } \\
\text { Blinding of outcome as- } \\
\text { sessment (detection bias) } \\
\text { All outcomes }\end{array}$ & Low risk & \\
\hline $\begin{array}{l}\text { Incomplete outcome data } \\
\text { (attrition bias) }\end{array}$ & Low risk & Double-blind \\
\hline
\end{tabular}


Cremonini 1986 (Continued)

All outcomes

Selective reporting (re- Unclear risk $\quad$ Information not available
porting bias)

\section{Dal Negro 2017}

\begin{tabular}{|c|c|}
\hline Methods & Randomised, double-blind, placebo-controlled, parallel, multi-centre (10). Duration 12 months \\
\hline \multirow[t]{2}{*}{ Participants } & $\begin{array}{l}467 \text { outpatients who were current or ex-smokers aged } 40 \text { to } 80 \text { years with GOLD stage II/III and a stable } \\
\text { therapeutic regimen for more than } 8 \text { weeks. Patients had to have experienced } 2 \text { or more acute COPD } \\
\text { exacerbations requiring medical intervention in the previous } 12 \text { months }\end{array}$ \\
\hline & $\begin{array}{l}\text { Exclusions: pregnant, lactating mother; lack of efficient contraception in a subject with child-bearing } \\
\text { potential; acute exacerbation of COPD within } 8 \text { weeks before inclusion; treatment with antibiotics and/ } \\
\text { or systemic steroids and/or hospitalisations within } 8 \text { weeks before inclusion; change in therapeutic reg- } \\
\text { imen for COPD in the last } 8 \text { weeks before inclusion; COPD stage IV; current or past diagnosis of asthma; } \\
\mathrm{FEV}_{1} \text { reversibility test showing change in } \mathrm{FEV},>400 \mathrm{~mL} 30 \text { minutes after inhalation of } 400 \mu \mathrm{g} \text { of salbuta- } \\
\text { mol pMDI; clinically significant or unstable concurrent disease or other significant renal impairment as } \\
\text { indicated by creatinine clearance }<25 \mathrm{~mL} / \mathrm{min} \text {; active peptic ulcer; liver cirrhosis }\end{array}$ \\
\hline
\end{tabular}

Mean age: $64.8 ; 74 \%$ male

Dropouts: $22 \%$ in erdosteine group; $22 \%$ in placebo group

\begin{tabular}{|c|c|c|}
\hline Interventions & \multicolumn{2}{|c|}{ Erdosteine $300 \mathrm{mg}$ twice daily or placebo } \\
\hline Outcomes & \multicolumn{2}{|c|}{ Primary outcome: number of acute exacerbations } \\
\hline & \multicolumn{2}{|c|}{$\begin{array}{l}\text { Secondary outcomes: spirometry parameters, COPD symptoms, quality of life, safety and tolerability of } \\
\text { erdosteine }\end{array}$} \\
\hline Notes & \multicolumn{2}{|c|}{ RESTORE study: multi-national study including 10 European countries funded by Edmond Pharma } \\
\hline \multicolumn{3}{|l|}{ Risk of bias } \\
\hline Bias & Authors' judgement & Support for judgement \\
\hline $\begin{array}{l}\text { Random sequence genera- } \\
\text { tion (selection bias) }\end{array}$ & Low risk & $\begin{array}{l}\text { An independent statistician generated a randomisation list of patient random } \\
\text { numbers using a pseudo-random number generator. Series of } 4 \text { patients for } \\
\text { each of the } 2 \text { strata were assigned to study sites to achieve, within each centre, } \\
\text { a balanced number of patients treated with erdosteine or placebo in each of } \\
\text { the } 2 \text { strata }\end{array}$ \\
\hline $\begin{array}{l}\text { Allocation concealment } \\
\text { (selection bias) }\end{array}$ & Low risk & $\begin{array}{l}\text { Erdosteine and placebo capsules were manufactured and provided by the } \\
\text { sponsor. Placebo was identical in composition, shape, colour, and size but } \\
\text { did not contain any active ingredients. Erdosteine or placebo capsules were } \\
\text { packed identically. The investigator or anyone at the study site was prevented } \\
\text { from knowing the allocation sequence with code labelling }\end{array}$ \\
\hline $\begin{array}{l}\text { Blinding of participants } \\
\text { and personnel (perfor- } \\
\text { mance bias) } \\
\text { All outcomes }\end{array}$ & Low risk & $\begin{array}{l}\text { Placebo was identical in composition, shape, colour, and size but did not con- } \\
\text { tain any active ingredients. Erdosteine or placebo capsules were packed iden- } \\
\text { tically. The investigator or anyone at the study site was prevented from know- } \\
\text { ing the allocation sequence with code labelling. The sponsor and the clinical } \\
\text { research associate were notified if there was a clinical reason for an individ- } \\
\text { ual's treatment to be unmasked by the investigator }\end{array}$ \\
\hline
\end{tabular}


Dal Negro 2017 (Continued)

Blinding of outcome as- Low risk Not specifically described in trial report, but in clinical trials, record outcome sessment (detection bias) assessors described as blinded

All outcomes

\begin{tabular}{|c|c|c|}
\hline $\begin{array}{l}\text { Incomplete outcome data } \\
\text { (attrition bias) } \\
\text { All outcomes }\end{array}$ & Unclear risk & $\begin{array}{l}\text { Approx } 20 \% \text { withdrew from both arms ( } 50 / 228 \text { from the intervention arm and } \\
52 / 239 \text { from the placebo arm) for similar reasons, but ITT analysis conducted } \\
\text { including over } 90 \% \text { of participants in both arms }\end{array}$ \\
\hline
\end{tabular}

\begin{tabular}{|c|c|c|}
\hline $\begin{array}{l}\text { Selective reporting (re- } \\
\text { porting bias) }\end{array}$ & Low risk & $\begin{array}{l}\text { Several outcomes of interest reported narratively as 'no difference' in publica- } \\
\text { tion, but study authors supplied required information upon request }\end{array}$ \\
\hline
\end{tabular}

\section{De Backer 2013}

\begin{tabular}{ll}
\hline Methods & Randomised, double-blind, placebo-controlled, cross-over. Duration 3 months \\
\hline Participants & $\begin{array}{l}12 \text { outpatients with GOLD stage II or III COPD, age } \geq 40 \text {, smoking history at least } 10 \text { pack-years but now } \\
\text { Smoke free, presence of COPD symptoms. } 9 \text { men and } 3 \text { women with mean age } 65,56 \text { pack-years, and } \\
\text { FEV } 65 \% \text {. All completed the study. Exclusions: recent exacerbation; allergy to or prior treatment with } \\
\text { NAC; PKU; untreated peptic ulcer; organ insufficiency; ongoing treatment with oral, IV, or IM steroids; } \\
\text { pregnancy or breastfeeding; treatment with oral cephalosporin }\end{array}$ \\
\hline Interventions & NAC 600 mg 3 times daily or placebo \\
\hline Outcomes & Measured at baseline and at end of each 3/12 treatment period: spirometry, PEFR, raw NO, specific air- \\
& way resistance from plethysmography, CT to look at airway geometry, serum glutathione, enzymes, \\
& SGRQ, ABG \\
\hline Belgian. Funded by an imaging company and a pharmaceutical company & $\begin{array}{l}\text { Dr Backer works for FluidDA, a functional respiratory imaging company, contracted by Zambon, manu- } \\
\text { facturer of NAC }\end{array}$ \\
& Responder analysis. Did not report on spirometry or SGRQ results for treatment groups as a whole. \\
These have been requested
\end{tabular}

\section{Risk of bias}

\begin{tabular}{lll}
\hline Bias & Authors' judgement & Support for judgement \\
\hline $\begin{array}{l}\text { Random sequence genera- } \\
\text { tion (selection bias) }\end{array}$ & Unclear risk & Computer-generated randomisation list used; no further details \\
\hline $\begin{array}{l}\text { Allocation concealment } \\
\text { (selection bias) }\end{array}$ & High risk & $\begin{array}{l}\text { Cross-over trial. Trial lasted from August 2009 to June 2012 for only } 12 \text { partici- } \\
\text { pants. No details on allocation or concealment procedures reported }\end{array}$ \\
\hline $\begin{array}{l}\text { Blinding of participants } \\
\text { and personnel (perfor- } \\
\text { mance bias) }\end{array}$ & High risk & $\begin{array}{l}\text { Participants were their own controls. No information about similarity of NAC } \\
\text { all outcomes }\end{array}$ \\
\hline $\begin{array}{l}\text { Blinding of outcome as- } \\
\text { sessment (detection bias) } \\
\text { All outcomes }\end{array}$ & High risk & $\begin{array}{l}\text { Cross-over trial with no washout period. Possible practice effects. Unsure how } \\
\text { blinded investigators were }\end{array}$ \\
\hline $\begin{array}{l}\text { Incomplete outcome data } \\
\text { (attrition bias) }\end{array}$ & Low risk & All participants completed the study \\
\hline
\end{tabular}


De Backer 2013 (Continued)

All outcomes

$\begin{array}{lll}\begin{array}{l}\text { Selective reporting (re- } \\ \text { porting bias) }\end{array} & \text { High risk } & \begin{array}{l}\text { Reported responder analysis. Did not report on spirometry or SGRQ results for } \\ \text { treatment groups as a whole }\end{array}\end{array}$

Selective reporting (re- High risk treatment groups as a whole

\section{Decramer 2005}

\begin{tabular}{|c|c|}
\hline Methods & Randomised, double-blind, placebo-controlled, parallel, multi-centre. ITT analysis. Duration 3 years \\
\hline \multirow[t]{3}{*}{ Participants } & $\begin{array}{l}523 \text { outpatients with smoking-related COPD. Age } 40 \text { to } 75 \text { years; post-bronchodilator } \mathrm{FEV}_{1} 40 \% \text { to } 70 \% \\
\text { predicted; reversibility }<12 \% \text { and } 200 \mathrm{~mL} \text {; FEV } / \text { /FVC } 88 \% \text { for men and } 89 \% \text { for women; history of at } \\
\text { least } 2 \text { exacerbations during } 2 \text { years before enrolment } \\
\text { Exclusions: intolerance of NAC, continuous treatment with oral steroids, NAC for } 3 / 12 \text { or longer, asth- } \\
\text { ma or atopy, other respiratory diseases, NYHA Class II or greater heart failure, GI disease, likely LTOT or } \\
\text { lung transplant, alpha } 1 \text { antitrypsin deficiency, enrolment in rehab or other study } 3 \text { months before this } \\
\text { study. ICS permitted, although steady dose recommended }\end{array}$ \\
\hline & $\begin{array}{l}\text { Mean age } 62 \text { (SD 8) years; } 79 \% \text { male; FEV } 1.65 \text { (SD 0.38) L; } 57 \% \text { (SD 9) predicted; } 46 \% \text { current smokers; } \\
70 \% \text { used ICS Yearly exacerbation rate (control group) } 2.5 \text { (SD 0.9) events }\end{array}$ \\
\hline & Dropouts: $70(27 \%)$ in NAC group and $99(37 \%)$ in placebo group $(P=0.018)$ \\
\hline Interventions & NAC $600 \mathrm{mg}$ daily vs placebo \\
\hline \multirow[t]{3}{*}{ Outcomes } & Yearly reduction in lung function and exacerbation rate \\
\hline & Secondary endpoints: quality of life (SGRQ), cost utility \\
\hline & Planned subgroup analyses - by baseline ICS dose and disease severity \\
\hline \multirow[t]{2}{*}{ Notes } & $\begin{array}{l}\text { European. BRONCUS study } \\
\text { Cost utility will be reported in another publication }\end{array}$ \\
\hline & $\begin{array}{l}\text { Data from mixed-effects model used in this study have been provided by Professor De Cramer for total } \\
\text { SGRQ scores. Change on NAC was - } 2.31 \text { and on placebo }-3.71 \\
\text { Add these to baseline (using baseline SD) } 36.7 \text { (16) and } 36.3 \text { (15) to get total SGRQ at end of study to en- } \\
\text { ter into RevMan }\end{array}$ \\
\hline
\end{tabular}

\section{Risk of bias}

\begin{tabular}{lll}
\hline Bias & Authors' judgement & Support for judgement \\
\hline $\begin{array}{l}\text { Random sequence genera- } \\
\text { tion (selection bias) }\end{array}$ & Low risk & Computer-generated randomisation list \\
\hline $\begin{array}{l}\text { Allocation concealment } \\
\text { (selection bias) }\end{array}$ & Low risk & Allocation concealed from study investigators \\
\hline $\begin{array}{l}\text { Blinding of participants } \\
\text { and personnel (perfor- } \\
\text { mance bias) }\end{array}$ & Low risk & Double-blind; identical placebo and active tablets \\
All outcomes & & \\
\hline
\end{tabular}

Blinding of outcome as-
$\begin{aligned} & \text { sessment (detection bias) } \\ & \text { All outcomes }\end{aligned}$


Decramer 2005 (Continued)

Incomplete outcome data High risk High and unbalanced dropout; 70/256 (27\%) and 99/267 (37\%) withdrew from (attrition bias) mucolytics and placebo, respectively. A greater number of placebo partici-

All outcomes pants withdrew consent ( 26 vs 13 ), experienced an adverse event leading to withdrawal (26 vs 19), or experienced worsening of disease/lack of efficacy (6 vs 2)

\begin{tabular}{l}
$\begin{array}{l}\text { Selective reporting (re- } \quad \text { Low risk } \\
\text { porting bias) }\end{array}$ \\
\hline
\end{tabular}

\section{Ekberg-Jansson 1999}

Methods $\quad$ Randomised, double-blind, placebo-controlled, parallel, multi-centre (41). PP analysis. Duration 6
months

\begin{tabular}{ll}
\hline Participants & 637 outpatients with chronic bronchitis defined by MRC \\
& 1 exacerbation in previous winter. Average age 58 years; $61 \%$ male; mean FEV $173 \%$ predicted; $100 \%$ \\
current smokers or ex-smokers. Exclusions: females of fertile age, FEV $1<40 \%$ predicted, significant re- & versibility, unstable non-respiratory disease, other respiratory disease, atopy, peptic ulcer, lactose in- \\
tolerance or daily purulent sputum. 134 dropped out
\end{tabular}

\begin{tabular}{ll}
\hline Interventions & N-isobutyrylcysteine (NIC) $300 \mathrm{mg}$ twice daily or placebo \\
\hline Outcomes & $\begin{array}{l}\text { Time to first exacerbation, exacerbation rate, days sick (judged by participants and investigators), lung } \\
\text { function, adverse effects }\end{array}$ \\
\hline Notes & European including British. New agent-free thiol donor derivative of NAC
\end{tabular}

\section{Risk of bias}

\begin{tabular}{|c|c|c|}
\hline Bias & Authors' judgement & Support for judgement \\
\hline $\begin{array}{l}\text { Random sequence genera- } \\
\text { tion (selection bias) }\end{array}$ & Unclear risk & Information not available \\
\hline $\begin{array}{l}\text { Allocation concealment } \\
\text { (selection bias) }\end{array}$ & Unclear risk & Information not available \\
\hline $\begin{array}{l}\text { Blinding of participants } \\
\text { and personnel (perfor- } \\
\text { mance bias) } \\
\text { All outcomes }\end{array}$ & Low risk & Double-blind \\
\hline $\begin{array}{l}\text { Blinding of outcome as- } \\
\text { sessment (detection bias) } \\
\text { All outcomes }\end{array}$ & Low risk & Double-blind \\
\hline $\begin{array}{l}\text { Incomplete outcome data } \\
\text { (attrition bias) } \\
\text { All outcomes }\end{array}$ & High risk & $\begin{array}{l}72 / 316(23 \%) \text { dropped out of the intervention arm and } 62 / 321 \text { (19\%) dropped } \\
\text { out of the placebo arm. There were more adverse events leading to discontinu- } \\
\text { ation in the intervention arm ( } 42 \text { vs } 25) \text {, and more dropouts in the placebo arm } \\
\text { were classified as "other reasons" ( } 34 \text { vs } 22 \text { ) }\end{array}$ \\
\hline $\begin{array}{l}\text { Selective reporting (re- } \\
\text { porting bias) }\end{array}$ & Low risk & Reported on main outcomes \\
\hline
\end{tabular}


Fukuchi 2016

\begin{tabular}{|c|c|}
\hline Methods & Randomised, double-blind, placebo-controlled, parallel. Duration 12 months \\
\hline \multirow[t]{3}{*}{ Participants } & $\begin{array}{l}408 \text { outpatients between } 20 \text { and } 85 \text { years of age with smoking history, post-bronchodilator ratio of } \mathrm{FEV}_{1} \\
\text { to forced vital capacity }(\mathrm{FVC})<70 \% \text {, and } \mathrm{FEV}_{1}<80 \% \text { predicted in the screening }\end{array}$ \\
\hline & $\begin{array}{l}\text { Exclusions: history of COPD exacerbation within } 7 \text { days before the start of oral administration of study } \\
\text { drugs; history of lung transplantation, pneumonectomy, or lung volume reduction surgery; clinically } \\
\text { severe disease (e.g. pulmonary tuberculosis) }\end{array}$ \\
\hline & Dropouts: $15 \%$ in lysozyme group; $17 \%$ in placebo group \\
\hline Interventions & Lysozyme $90 \mathrm{mg} 3$ times daily or placebo \\
\hline Outcomes & $\begin{array}{l}\text { Primary outcome: prevention of COPD exacerbation (as assessed by exacerbation rate and time to first } \\
\text { exacerbation) Secondary outcomes: respiratory function assessed by spirometry, health status as- } \\
\text { sessed by CAT }\end{array}$ \\
\hline Notes & $\begin{array}{l}\text { Japanese. This study was conducted with funds from Aska Pharmaceutical Co., Ltd.; Nippon Shinyaku } \\
\text { Co., Ltd.; and Eisai Co., Ltd. Two patients were withdrawn from the study before the start of oral admin- } \\
\text { istration }\end{array}$ \\
\hline
\end{tabular}

\section{Risk of bias}

Bias Authors' judgement Support for judgement

Random sequence genera- Low risk After the screening period, patients were randomly assigned to lysozyme or tion (selection bias) placebo treatment in a ratio of 1:1. Correspondence with trial authors confirmed that "independent statisticians from sponsors made a randomized sequence. The randomization sequence was made by permuted block method with variable block size of block sizes 2 and 4 and equal randomization ratio, using SAS"

\begin{tabular}{|c|c|c|}
\hline $\begin{array}{l}\text { Allocation concealment } \\
\text { (selection bias) }\end{array}$ & Low risk & $\begin{array}{l}\text { Correspondence with trial authors confirmed "based on the randomized se- } \\
\text { quence, the study drug was placed in a box and sealed" }\end{array}$ \\
\hline $\begin{array}{l}\text { Blinding of participants } \\
\text { and personnel (perfor- } \\
\text { mance bias) } \\
\text { All outcomes }\end{array}$ & Low risk & Study used a "matching placebo" \\
\hline $\begin{array}{l}\text { Blinding of outcome as- } \\
\text { sessment (detection bias) } \\
\text { All outcomes }\end{array}$ & Low risk & $\begin{array}{l}\text { Correspondence with trial authors confirmed that outcome assessors re- } \\
\text { mained blind to group allocation }\end{array}$ \\
\hline $\begin{array}{l}\text { Incomplete outcome data } \\
\text { (attrition bias) } \\
\text { All outcomes }\end{array}$ & Low risk & $\begin{array}{l}31 / 202(15 \%) \text { dropped out of the intervention arm and } 35 / 204(35 \%) \text { dropped } \\
\text { out of the placebo arm. Correspondence with trial authors confirmed that rea- } \\
\text { sons for withdrawal were balanced between trial arms }\end{array}$ \\
\hline $\begin{array}{l}\text { Selective reporting (re- } \\
\text { porting bias) }\end{array}$ & Low risk & $\begin{array}{l}\text { Quality of life score not reported numerically in published trial report but sup- } \\
\text { plied by trial authors on request }\end{array}$ \\
\hline
\end{tabular}

Grassi 1976

$\begin{array}{ll}\text { Methods } & \begin{array}{l}\text { Randomised, double-blind, placebo-controlled, parallel, multi-centre (6). PP analysis. Duration } 6 \\ \text { months }\end{array}\end{array}$


Grassi 1976 (Continued)

Participants

Interventions

80 outpatients with chronic bronchitis defined by American and British criteria. 11 dropped out. Mean age 60.9 years; $80 \%$ male

\begin{tabular}{ll} 
& NAC $600 \mathrm{mg}$ daily or placebo for 3 days per week \\
\hline Outcomes & Exacerbations, clinical symptoms (3 months), sputum characteristics, adverse effects \\
\hline Notes & $\begin{array}{l}\text { Italian. SD calculated from paper. } 3 \text { or more exacerbations counted as } 3.1 \text { to } 2 \text { exacerbations counted } \\
\text { as } 1.5\end{array}$
\end{tabular}

\section{Risk of bias}

\begin{tabular}{|c|c|c|}
\hline Bias & Authors' judgement & Support for judgement \\
\hline $\begin{array}{l}\text { Random sequence genera- } \\
\text { tion (selection bias) }\end{array}$ & Unclear risk & Information not available \\
\hline $\begin{array}{l}\text { Allocation concealment } \\
\text { (selection bias) }\end{array}$ & Unclear risk & Information not available \\
\hline $\begin{array}{l}\text { Blinding of participants } \\
\text { and personnel (perfor- } \\
\text { mance bias) } \\
\text { All outcomes }\end{array}$ & Low risk & Double-blind; matching placebo \\
\hline $\begin{array}{l}\text { Blinding of outcome as- } \\
\text { sessment (detection bias) } \\
\text { All outcomes }\end{array}$ & Unclear risk & Double-blind \\
\hline $\begin{array}{l}\text { Incomplete outcome data } \\
\text { (attrition bias) } \\
\text { All outcomes }\end{array}$ & Unclear risk & $\begin{array}{l}5 / 40(13 \%) \text { dropped out of intervention arm and } 6 / 40(15 \%) \text { of placebo arm. A } \\
\text { further } 4 \text { were excluded ( } 3 \text { placebo and } 1 \text { intervention) due to ineffectiveness } \\
\text { of treatment. Reasons for } 11 \text { dropouts were not given }\end{array}$ \\
\hline $\begin{array}{l}\text { Selective reporting (re- } \\
\text { porting bias) }\end{array}$ & Low risk & Main outcomes reported \\
\hline
\end{tabular}

\section{Grassi 1994}

\begin{tabular}{ll}
\hline Methods & Randomised, double-blind, placebo-controlled, parallel, multi-centre. PP analysis. Duration 3 months \\
\hline Participants & $\begin{array}{l}135 \text { outpatients with chronic bronchitis with at least } 2 \text { exacerbations previous winter randomly as- } \\
\text { signed to } 1 \text { of } 3 \text { treatments. Participants aged } 40 \text { and } 75, \text { mean age } 61.8 \text { years; chronic bronchitis for at } \\
\text { least } 5 \text { years; } F E V_{1} 56.7 \% \text { predicted; } 76 \% \text { smokers For this analysis, } n=87.4 \text { dropped out }\end{array}$ \\
\hline Interventions & $\begin{array}{l}\text { Carbocysteine-sobrerol } 1 \text { dose daily, placebo } 1 \text { dose daily, or alternating active-placebo for } 10 \text { days } \\
\text { each, for } 3 \text { months. } 1 \text { treatment group was intermittent; this is not included in the analysis }\end{array}$ \\
\hline Outcomes & Exacerbations, symptoms, sputum characteristics \\
\hline Notes & Italian. Published in Italian; therefore relying on translation. SD calculated from paper \\
\hline Risk of bias &
\end{tabular}

\section{Bias \\ Authors' judgement Support for judgement}


Grassi 1994 (Continued)

\begin{tabular}{|c|c|c|}
\hline $\begin{array}{l}\text { Random sequence genera- } \\
\text { tion (selection bias) }\end{array}$ & Unclear risk & Information not available \\
\hline $\begin{array}{l}\text { Allocation concealment } \\
\text { (selection bias) }\end{array}$ & Unclear risk & Information not available \\
\hline $\begin{array}{l}\text { Blinding of participants } \\
\text { and personnel (perfor- } \\
\text { mance bias) } \\
\text { All outcomes }\end{array}$ & Low risk & Double-blind \\
\hline $\begin{array}{l}\text { Blinding of outcome as- } \\
\text { sessment (detection bias) } \\
\text { All outcomes }\end{array}$ & Low risk & Double-blind \\
\hline $\begin{array}{l}\text { Incomplete outcome data } \\
\text { (attrition bias) } \\
\text { All outcomes }\end{array}$ & Low risk & $\begin{array}{l}3 / 45(7 \%) \text { from the intervention group and } 1 / 42(2 \%) \text { from the placebo group } \\
\text { dropped out. Reasons for withdrawal from the intervention group included re- } \\
\text { fusal of treatment, non-attendance at follow-up, and an adverse event. The } \\
\text { only participant who dropped out of the placebo group refused treatment }\end{array}$ \\
\hline $\begin{array}{l}\text { Selective reporting (re- } \\
\text { porting bias) }\end{array}$ & Low risk & Main outcomes reported \\
\hline
\end{tabular}

\section{Grillage 1985}

Methods $\quad$ Randomised, double-blind, placebo-controlled, parallel, multi-centre (17). PP analysis. Duration 6
months

Participants

109 general practice patients with chronic bronchitis defined by MRC, reversibility < $20 \%$. Exclusions: severe hepatic or renal impairment or peptic ulcer; taking mucolytics or steroids. Participants were over 40 years of age; mean PEFR $232 \mathrm{~L} / \mathrm{min}$, with episodes of bronchitis in previous winters. 11 dropped out, including 2 who died

\begin{tabular}{ll}
\hline Interventions & Carbocysteine $750 \mathrm{mg} 3$ times daily or placebo \\
\hline Outcomes & Exacerbations, lung function, adverse effects \\
\hline Notes & $\begin{array}{l}\text { British. Excluded from original review, but with new comparison, "pts with no exacerbations" can now } \\
\text { be included }\end{array}$
\end{tabular}

\section{Risk of bias}

\begin{tabular}{lll}
\hline Bias & Authors' judgement & Support for judgement \\
\hline $\begin{array}{l}\text { Random sequence genera- } \\
\text { tion (selection bias) }\end{array}$ & Unclear risk & Information not available \\
\hline $\begin{array}{l}\text { Allocation concealment } \\
\text { (selection bias) }\end{array}$ & Unclear risk & Information not available \\
\hline $\begin{array}{l}\text { Blinding of participants } \\
\text { and personnel (perfor- } \\
\text { mance bias) }\end{array}$ & Low risk & Double-blind; matching placebo \\
\begin{tabular}{l} 
All outcomes \\
\hline
\end{tabular} & \\
\hline
\end{tabular}


Grillage 1985 (Continued)

Blinding of outcome as-
sessment (detection bias)

All outcomes

\begin{tabular}{lll}
\hline $\begin{array}{l}\text { Incomplete outcome data } \\
\text { (attrition bias) }\end{array}$ & Unclear risk & $\begin{array}{l}6 / 54(11 \%) \text { dropped out of the intervention arm: } 3 \text { due to adverse events, } 2 \text { due } \\
\text { to non-compliance, and } 1 \text { moved to another area. } 3 / 55 \text { (5\%) dropped out of } \\
\text { the placebo arm: } 2 \text { due to adverse events, } 1 \text { due to inefficacy of the trial med- } \\
\text { ication }\end{array}$ \\
\hline $\begin{array}{l}\text { Selective reporting (re- } \\
\text { porting bias) }\end{array}$ & Low risk & Reported on main outcomes \\
\hline
\end{tabular}

\section{Hansen 1994}

Methods Randomised, double-blind, placebo-controlled, parallel, multi-centre (6). 4-week run-in. PP analysis.
Duration 5 months

\begin{tabular}{ll}
\hline Participants & $\begin{array}{l}\text { 153 outpatients with chronic bronchitis defined by MRC. At least } 2 \text { exacerbations in past year; FEV }{ }_{1} \geq \\
50 \% \text { predicted; }<20 \% \text { reversibility. } 100 \% \text { had smoked. Exclusions were those with atopy or heart dis- } \\
\text { ease and on long-term antibiotics. Mean age } 51.4 \text { years; } 43 \% \text { male. Mean FEV } 12.34 \text { L; } 24 \text { dropped out }\end{array}$ \\
\hline Interventions & NAC 600 mg twice daily or placebo \\
\hline Outcomes & $\begin{array}{l}\text { Exacerbations, subjective symptom scores, global well-being, lung function, adverse effects. Sick days } \\
\text { not assessed }\end{array}$ \\
\hline Notes & Danish
\end{tabular}

\section{Risk of bias}

\begin{tabular}{|c|c|c|}
\hline Bias & Authors' judgement & Support for judgement \\
\hline $\begin{array}{l}\text { Random sequence genera- } \\
\text { tion (selection bias) }\end{array}$ & Low risk & Randomisation in blocks of 4 provided by third party \\
\hline $\begin{array}{l}\text { Allocation concealment } \\
\text { (selection bias) }\end{array}$ & Unclear risk & Information not available \\
\hline $\begin{array}{l}\text { Blinding of participants } \\
\text { and personnel (perfor- } \\
\text { mance bias) } \\
\text { All outcomes }\end{array}$ & Low risk & Double-blind; matching placebo \\
\hline $\begin{array}{l}\text { Blinding of outcome as- } \\
\text { sessment (detection bias) } \\
\text { All outcomes }\end{array}$ & Low risk & Double-blind \\
\hline $\begin{array}{l}\text { Incomplete outcome data } \\
\text { (attrition bias) } \\
\text { All outcomes }\end{array}$ & High risk & $\begin{array}{l}16 / 75(21 \%) \text { dropped out of the intervention arm and } 8 / 78(10 \%) \text { from the } \\
\text { placebo arm. Reasons for dropout not reported }\end{array}$ \\
\hline $\begin{array}{l}\text { Selective reporting (re- } \\
\text { porting bias) }\end{array}$ & Low risk & Main outcomes reported \\
\hline
\end{tabular}


Jackson 1984

\begin{tabular}{ll} 
Methods & $\begin{array}{l}\text { Randomised, double-blind, placebo-controlled, parallel, multi-centre (16). PP analysis. Duration } 3 \\
\text { months }\end{array}$ \\
\hline Participants & $\begin{array}{l}155 \text { general practice patients with chronic bronchitis defined by MRC. 88\% had smoked. Exclusions } \\
\text { were those with other serious respiratory disease or peptic ulcer and those on long-term antibiotics or } \\
\text { requiring mucolytics. Mean age } 63 \text { years; } 67 \% \text { male. } 34 \text { dropped out }\end{array}$ \\
\hline
\end{tabular}

\begin{tabular}{ll}
\hline Interventions & NAC 200 mg 3 times daily or placebo \\
\hline Outcomes & $\begin{array}{l}\text { Exacerbations, subjective symptom scores, clinical signs, radiological appearance, global well-being, } \\
\text { adverse effects }\end{array}$ \\
\hline Notes & $\begin{array}{l}\text { British. Excluded from original review, but with new comparison, "pts with no exacerbations" can now } \\
\text { be included }\end{array}$
\end{tabular}

\section{Risk of bias}

\begin{tabular}{lll}
\hline Bias & Authors' judgement & Support for judgement \\
\hline $\begin{array}{l}\text { Random sequence genera- } \\
\text { tion (selection bias) }\end{array}$ & Unclear risk & Information not available \\
\hline $\begin{array}{l}\text { Allocation concealment } \\
\text { (selection bias) }\end{array}$ & Unclear risk & Information not available \\
\hline $\begin{array}{l}\text { Blinding of participants } \\
\text { and personnel (perfor- } \\
\text { mance bias) }\end{array}$ & Low risk & Double-blind; matching placebo \\
All outcomes & \\
\hline $\begin{array}{l}\text { Blinding of outcome as- } \\
\text { sessment (detection bias) } \\
\text { All outcomes }\end{array}$ & Low risk & Double-blind \\
\hline $\begin{array}{l}\text { Incomplete outcome data } \\
\text { (attrition bias) } \\
\text { All outcomes }\end{array}$ & High risk & $\begin{array}{l}\text { 22\% overall dropout rate (34/155). 4 participants withdrew from the interven- } \\
\text { tion arm due to adverse events and 5 from the placebo arm. Other reasons for } \\
\text { withdrawal from each arm not given }\end{array}$ \\
\hline $\begin{array}{l}\text { Selective reporting (re- } \\
\text { porting bias) }\end{array}$ & Unclear risk & None detected \\
\hline
\end{tabular}

\section{Johnson 2016}

\begin{tabular}{|c|c|}
\hline Methods & Randomised, double-blind, placebo-controlled, parallel. Duration 8 weeks \\
\hline \multirow[t]{3}{*}{ Participants } & $\begin{array}{l}51 \text { outpatients with chronic cough and sputum production. Principal eligibility criteria were as follows: } \\
\text { (1) ratio of post-bronchodilator FEV } \mathrm{F}_{1} / \mathrm{FVC}<0.70 \text { along with } \mathrm{FEV}_{1}<65 \% \text { predicted; ( } 2 \text { ) age }>40 \text { years and } \\
<85 \text { years; (3) current or past history of cigarette smoking of at least } 10 \text { pack-years; (4) no COPD exacer- } \\
\text { bation in the last } 4 \text { weeks; (5) presence of chronic bronchitis }\end{array}$ \\
\hline & $\begin{array}{l}\text { Exclusions: (1) primary clinical diagnosis of asthma; (2) uncompensated heart failure; (3) cirrhosis with } \\
\text { ascites and edema; (4) estimated glomerular filtration rate } 30 \mathrm{~mL} / \mathrm{min} / 1.73 \mathrm{~m}^{2} \text {; (5) use of long-acting ni- } \\
\text { trates; (6) inability to provide informed consent }\end{array}$ \\
\hline & Mean age 70 years; average $\mathrm{FEV}_{1} 40 \%$ predicted \\
\hline
\end{tabular}


Johnson 2016 (Continued)

Dropouts: $15 \%$ in NAC group; $8 \%$ in placebo group

\begin{tabular}{ll}
\hline Interventions & NAC 1800 mg twice daily or placebo \\
\hline Outcomes & Primary outcome: change in total score of the SGRQ \\
& $\begin{array}{l}\text { Secondary outcomes: changes in the } 3 \text { domains of the SGRQ, CBSAS, SF-36, lung function with post- } \\
\text { bronchodilator spirometry }\end{array}$ \\
\hline Notes & $\begin{array}{l}\text { American. Funded by the Minnesota Veterans Medical Research and Education Foundation, the Health- } \\
\text { Partners Institute of Education and Research, and the University of Minnesota Graduate School. Trial } \\
\text { terminated due to safety concerns before enrolment completed. Unclear what impact this had on re- } \\
\text { sults reported. Study authors conducted an analysis to determine the probability of a statistically sig- } \\
\text { nificant difference in SGRQ had the trial continued, and concluded that had a mid-study futility analysis } \\
\text { been incorporated into the protocol, this result in itself would have terminated the study }\end{array}$ \\
\hline
\end{tabular}

\section{Risk of bias}

\begin{tabular}{|c|c|c|}
\hline Bias & Authors' judgement & Support for judgement \\
\hline $\begin{array}{l}\text { Random sequence genera- } \\
\text { tion (selection bias) }\end{array}$ & Low risk & $\begin{array}{l}\text { At each site, patients were randomized } 1: 1 \text { to active drug or placebo in permut- } \\
\text { ed blocks of size } 2 \text {. Research pharmacists at each site were the only study per- } \\
\text { sonnel with access to the randomisation list }\end{array}$ \\
\hline $\begin{array}{l}\text { Allocation concealment } \\
\text { (selection bias) }\end{array}$ & Low risk & $\begin{array}{l}\text { Research pharmacists at each site were the only study personnel with access } \\
\text { to the randomisation list; they assigned treatment accordingly. All other study } \\
\text { personnel and study patients were fully blinded to the allocation arm }\end{array}$ \\
\hline $\begin{array}{l}\text { Blinding of participants } \\
\text { and personnel (perfor- } \\
\text { mance bias) } \\
\text { All outcomes }\end{array}$ & Low risk & $\begin{array}{l}\text { Placebo tablets were indistinguishable from active drug in terms of appear- } \\
\text { ance, effervescence, taste, and odour }\end{array}$ \\
\hline $\begin{array}{l}\text { Blinding of outcome as- } \\
\text { sessment (detection bias) } \\
\text { All outcomes }\end{array}$ & Low risk & $\begin{array}{l}\text { All study personnel and study patients were fully blinded to the allocation arm. } \\
\text { The study team was unblinded to efficacy outcomes only after the decision } \\
\text { had been made to terminate the trial }\end{array}$ \\
\hline $\begin{array}{l}\text { Incomplete outcome data } \\
\text { (attrition bias) } \\
\text { All outcomes }\end{array}$ & Low risk & $\begin{array}{l}4 / 27(15 \%) \text { participants in the intervention arm did not complete the trial; } 2 / 24 \\
(8 \%) \text { participants in the placebo arm did not complete. One placebo partici- } \\
\text { pant was unable to make the follow-up visit; the remainder did not complete } \\
\text { due to early trial termination }\end{array}$ \\
\hline $\begin{array}{l}\text { Selective reporting (re- } \\
\text { porting bias) }\end{array}$ & Low risk & $\begin{array}{l}\text { All planned outcomes of interest in this review reported fully. SGRQ only out- } \\
\text { come listed on clinical trials record }\end{array}$ \\
\hline
\end{tabular}

\section{Malerba 2004}

\begin{tabular}{ll}
\hline Methods & $\begin{array}{l}\text { Randomised, double-blind, placebo-controlled, parallel, multi-centre (26). ITT and OT. Duration } 12 \\
\text { months }\end{array}$ \\
\hline Participants & 242 participants with COPD (ATS definition) and chronic bronchitis. Age 40 to $75 ;$ FEV $160 \%$ to $80 \%$ \\
& $\begin{array}{l}\text { (GOLD stage IIA); pathological chest auscultatory findings; at least } 1 \text { exacerbation in previous } 12 \\
\text { months } \\
\text { Exclusions: CF, bronchiectasis, asthma, centrilobular emphysema, peptic ulcer or liver, kidney or heart } \\
\text { insufficiency }\end{array}$
\end{tabular}


Malerba 2004 (Continued)

Other mucoactive and anti-cough agents, OCS, or ICS not permitted. ICS withdrawn at least 4 weeks before study

Mean age 60 years; 75\% had smoking history; FEV 12.12 (SD 0.6) L; mean 2.7 (SD 1.3) exacerbations in past 12 months

Dropouts: $34(16 \%)$

\begin{tabular}{ll}
\hline Interventions & Ambroxol 75 mg twice daily or placebo \\
\hline Outcomes & Exacerbations over first 6 months (winter period) and at 12 months \\
& $\begin{array}{l}\text { Secondary: cough intensity and frequency, difficult expectoration, dyspnoea, days on antibiotics, num- } \\
\text { ber of working days lost, number of days of hospitalisation }\end{array}$ \\
\hline Notes & $\begin{array}{l}\text { Italian. AMETHIST study } \\
\text { Post hoc analysis on participants with more severe condition }\end{array}$ \\
\hline
\end{tabular}

\section{Risk of bias}

\begin{tabular}{|c|c|c|}
\hline Bias & Authors' judgement & Support for judgement \\
\hline $\begin{array}{l}\text { Random sequence genera- } \\
\text { tion (selection bias) }\end{array}$ & Unclear risk & Information not available \\
\hline $\begin{array}{l}\text { Allocation concealment } \\
\text { (selection bias) }\end{array}$ & Unclear risk & Information not available \\
\hline $\begin{array}{l}\text { Blinding of participants } \\
\text { and personnel (perfor- } \\
\text { mance bias) } \\
\text { All outcomes }\end{array}$ & Low risk & Double-blind \\
\hline $\begin{array}{l}\text { Blinding of outcome as- } \\
\text { sessment (detection bias) } \\
\text { All outcomes }\end{array}$ & Low risk & Double-blind \\
\hline $\begin{array}{l}\text { Incomplete outcome data } \\
\text { (attrition bias) } \\
\text { All outcomes }\end{array}$ & Low risk & $\begin{array}{l}14 \% \text { dropout rate }(34 / 242) \text {, but only } 3 \% \text { excluded from intention-to-treat } \\
\text { analysis }\end{array}$ \\
\hline $\begin{array}{l}\text { Selective reporting (re- } \\
\text { porting bias) }\end{array}$ & Low risk & Main outcomes reported; some post hoc analysis \\
\hline
\end{tabular}

\section{McGavin 1985}

\begin{tabular}{|c|c|}
\hline Methods & $\begin{array}{l}\text { Randomised, double-blind, placebo-controlled, parallel, multi-centre (26). PP analysis. Duration } 5 \\
\text { months }\end{array}$ \\
\hline Participants & $\begin{array}{l}244 \text { participants entered the study, with } 200 \text { participants randomly assigned. } 181 \text { randomly assigned } \\
\text { appropriately (others ineligible or untraceable). Chronic bronchitis defined by MRC; } 1 \text { or more exacer- } \\
\text { bations per year for the past } 3 \text { years; } \mathrm{FEV}_{1}<50 \% \text { and } \mathrm{FEV}_{1} / \mathrm{FVC}<70 \% \text { predicted. Mean } \mathrm{FEV} \mathrm{F}_{1} 0.86 \mathrm{~L} \text {. Mean } \\
\text { age } 63.4 \text { years; } 85 \% \text { male. } 99 \% \text { current smokers or ex-smokers. } 148 \text { completed } 5 \text { months of treatment }\end{array}$ \\
\hline Interventions & NAC 200 mg 3 times daily or placebo \\
\hline Outcomes & Exacerbations, days of antibiotics, days in bed, $\mathrm{FEV}_{1}$ and VC, adverse effects \\
\hline
\end{tabular}


McGavin 1985 (Continued)

Notes
British. BTS research committee. Mean exacerbation rate given by study authors does not agree with what we calculated from their raw data. Have used authors' rates. Have used SE from body of text (same value reported in abstract as SD). For post-treatment $\mathrm{FEV}_{1}$, SD estimated from baseline data

\section{Risk of bias}

\begin{tabular}{|c|c|c|}
\hline Bias & Authors' judgement & Support for judgement \\
\hline $\begin{array}{l}\text { Random sequence genera- } \\
\text { tion (selection bias) }\end{array}$ & Unclear risk & Information not available \\
\hline $\begin{array}{l}\text { Allocation concealment } \\
\text { (selection bias) }\end{array}$ & Unclear risk & Information not available \\
\hline $\begin{array}{l}\text { Blinding of participants } \\
\text { and personnel (perfor- } \\
\text { mance bias) } \\
\text { All outcomes }\end{array}$ & Low risk & Double-blind; matching placebo \\
\hline $\begin{array}{l}\text { Blinding of outcome as- } \\
\text { sessment (detection bias) } \\
\text { All outcomes }\end{array}$ & Low risk & Double-blind \\
\hline $\begin{array}{l}\text { Incomplete outcome data } \\
\text { (attrition bias) } \\
\text { All outcomes }\end{array}$ & High risk & $\begin{array}{l}52 / 200(26 \%) \text { randomised participants did not complete the trial. } 14 \text { were } \\
\text { found to be 'ineligible' ( } 10 \text { in the intervention group and } 4 \text { in the placebo } \\
\text { group), and a further } 5 \text { were lost from the intervention group through "admin- } \\
\text { istrative error". Of the remaining eligible participants, } 13 \text { dropped out from the } \\
\text { intervention group and } 20 \text { from the placebo group. The imbalance in numbers } \\
\text { is largely due to more participants in the placebo group dropping out due to } \\
\text { being "too ill" }\end{array}$ \\
\hline
\end{tabular}

Selective reporting (re- Unclear risk Outcomes not stated clearly, viz "the effect" of ...
porting bias)

\section{Meister 1986}

\begin{tabular}{ll}
\hline Methods & Randomised, double-blind, placebo-controlled, parallel, multi-centre (54). Duration 6 months \\
\hline Participants & $\begin{array}{l}252 \text { outpatients with chronic bronchitis defined by WHO. At least } 1 \text { exacerbation in the past winter. } 10 \\
\text { patients with asthma and chronic bronchitis were included. Exclusions: those who had received at least } \\
14 \text { days of antibiotics for chronic bronchitis in the past } 6 \text { months; pregnancy. Average age } 57.2 \text { years; } \\
59 \% \text { male. Average PEFR } 303 \text { L/min. } 88 \% \text { had smoked. } 71 \text { dropped out }\end{array}$ \\
\hline
\end{tabular}

\begin{tabular}{ll}
\hline Interventions & NAC $300 \mathrm{mg}$ twice daily or placebo \\
\hline Outcomes & Exacerbations, days sick, concomitant treatment, adverse effects \\
\hline Notes & German. Provided by Zambon. Not published
\end{tabular}

\section{Risk of bias}

\begin{tabular}{lll}
\hline Bias & Authors' judgement & Support for judgement \\
\hline $\begin{array}{l}\text { Random sequence genera- } \\
\text { tion (selection bias) }\end{array}$ & Unclear risk & Information not available \\
\hline
\end{tabular}


Meister 1986 (Continued)

Allocation concealment Unclear risk Information not available
(selection bias)

\begin{tabular}{|c|c|c|}
\hline $\begin{array}{l}\text { Blinding of participants } \\
\text { and personnel (perfor- } \\
\text { mance bias) } \\
\text { All outcomes }\end{array}$ & Low risk & Double-blind \\
\hline $\begin{array}{l}\text { Blinding of outcome as- } \\
\text { sessment (detection bias) } \\
\text { All outcomes }\end{array}$ & Unclear risk & Double-blind \\
\hline $\begin{array}{l}\text { Incomplete outcome data } \\
\text { (attrition bias) } \\
\text { All outcomes }\end{array}$ & High risk & $\begin{array}{l}38 / 128(30 \%) \text { dropped out of the intervention group and } 33 / 124(27 \%) \\
\text { dropped out of the placebo group. Reasons were given and were balanced be- } \\
\text { tween arms; the trialist reported that sensitivity analysis suggested no impor- } \\
\text { tant differences between those who dropped out and those who remained in } \\
\text { the study. Results are reported for those who completed, rather than results of } \\
\text { an intention-to-treat analysis. High attrition for a trial of } 6 \text { months' duration, } \\
\text { so judged to be at high risk }\end{array}$ \\
\hline
\end{tabular}

Selective reporting (re- High risk Not published

porting bias)

\section{Meister 1999}

\begin{tabular}{ll}
\hline Methods & $\begin{array}{l}\text { Randomised, double-blind, placebo-controlled, parallel, multi-centre (19). PP and ITT analyses report- } \\
\text { ed. Duration } 6 \text { months }\end{array}$
\end{tabular}
ed. Duration 6 months

\section{Participants}

246 outpatients with chronic bronchitis as defined by WHO and $\mathrm{FEV}_{1}>50 \%$ predicted. 215 completed 6 months. At least 1 exacerbation in the past winter. Exclusions: those who had antibiotics in past 2 months, peptic ulcer disease, neoplasia, allergy to essential oils, pregnancy, lactation, severe concomitant disease. AveraMoretti 2004: age 57 years, 44\% male. Mean FEV $178 \%$ predicted. 55\% had smoked. 42 dropped out

\begin{tabular}{ll}
\hline Interventions & Myrtol $300 \mathrm{mg} 3$ times daily or placebo \\
\hline Outcomes & Exacerbations, number of exacerbations requiring antibiotics, well-being, adverse effects \\
\hline Notes & $\begin{array}{l}\text { German. Abstract provided by Douglas Pharmaceuticals. Full paper (English) provided by Pohl- } \\
\text { Boskamp. PP analysis used in review (participants completing } 6 \text { months). Results of ITT analysis consis- } \\
\text { tent with PP analysis }\end{array}$ \\
\hline
\end{tabular}

\section{Risk of bias}

\begin{tabular}{lll}
\hline Bias & Authors' judgement & Support for judgement \\
\hline $\begin{array}{l}\text { Random sequence genera- } \\
\text { tion (selection bias) }\end{array}$ & Unclear risk & Information not available \\
\hline $\begin{array}{l}\text { Allocation concealment } \\
\text { (selection bias) }\end{array}$ & Unclear risk & Information not available \\
\hline $\begin{array}{l}\text { Blinding of participants } \\
\text { and personnel (perfor- } \\
\text { mance bias) }\end{array}$ & Low risk & Double-blind; matched placebo \\
\end{tabular}


Meister 1999 (Continued)

All outcomes

Blinding of outcome as- $\quad$ Low risk Double-blind
sessment (detection bias)
All outcomes

Incomplete outcome data Unclear risk

(attrition bias)

260 participants received study medication at least once, of whom $42(16 \%)$

All outcomes discontinued the study prematurely. The ITT population comprised those who has received study medication for at least 1 month. 12/122 (10\%) dropped out of the intervention ITT group and 19/124 (15\%) from the placebo ITT arm. Reasons were balanced

Selective reporting (re- Low risk $\quad$ Reported on main outcomes: both PP and ITT
porting bias)

\section{Moretti 2004}

\begin{tabular}{ll}
\hline Methods & $\begin{array}{l}\text { Randomised, double-blind, placebo-controlled, parallel, multi-centre (9). PP analysis reported. Dura- } \\
\text { tion } 8 \text { months }\end{array}$
\end{tabular}

Participants

155 outpatients with COPD defined by ERS. Age 25 to 85 years; 1 or more exacerbations in previous winter; $\mathrm{FEV}_{1}<70 \%$ predicted; CXR no acute lung disease; smoking history $>20$ pack-years; stable and at least 4 weeks since last exacerbation

Exclusions: continuous treatment with oral steroids or expectorants; rapidly progressive bronchial disease; serious comorbidity; asthma; known poor compliance

Mean age 67 years; $80 \%$ male; $33 \%$ smokers; $\mathrm{FEV}_{1}$ after salbutamol $1.68 \mathrm{~L}$ (SD 0.31) in erdosteine group and $1.59 \mathrm{~L}(0.29)$ in placebo group

Dropouts: 31/155 (20\%). Equal in both groups and similar reasons. 63 in mucolytic group and 61 in placebo group completed

\begin{tabular}{ll}
\hline Interventions & Erdosteine 300 mg twice daily or placebo \\
\hline Outcomes & $\begin{array}{l}\text { Exacerbation frequency, duration, hospitalisation, lung function, 6-minute walk test, qua } \\
\text { (SGRQ), pharmacoeconomic analysis }\end{array}$ \\
\hline Notes & Italian. EQUALIFE study \\
& Mucolytic group had (insignificantly) more males and better lung function at baseline
\end{tabular}

\section{Risk of bias}

\begin{tabular}{lll}
\hline Bias & Authors' judgement & Support for judgement \\
\hline $\begin{array}{l}\text { Random sequence genera- } \\
\text { tion (selection bias) }\end{array}$ & Unclear risk & Information not available \\
\hline $\begin{array}{l}\text { Allocation concealment } \\
\text { (selection bias) }\end{array}$ & Unclear risk & Information not available \\
\hline $\begin{array}{l}\text { Blinding of participants } \\
\text { and personnel (perfor- } \\
\text { mance bias) }\end{array}$ & Low risk & Double-blind \\
All outcomes & & \\
\hline
\end{tabular}


Moretti 2004 (Continued)

Blinding of outcome as- $\quad$ Low risk $\quad$ Double-blind
sessment (detection bias)

All outcomes

\begin{tabular}{lll}
\hline $\begin{array}{l}\text { Incomplete outcome data } \\
\text { (attrition bias) } \\
\text { All outcomes }\end{array}$ & Unclear risk & $\begin{array}{l}16 / 79(20 \%) \text { dropped out of the intervention group and 15/76 (20\%) dropped } \\
\text { out of the placebo group. Reasons were balanced }\end{array}$ \\
\hline $\begin{array}{l}\text { Selective reporting (re- } \\
\text { porting bias) }\end{array}$ & Low risk & Reported all primary outcomes \\
\hline
\end{tabular}

\section{Nowak 1999}

\begin{tabular}{ll}
\hline Methods & $\begin{array}{l}\text { Randomised, double-blind, placebo-controlled, parallel, multi-centre (10 centres). PP analysis. Dura- } \\
\text { tion "long term" means } 8 \text { months }\end{array}$ \\
\hline Participants & $\begin{array}{l}313 \text { outpatients with COPD (diagnostic criteria not clear). Mean age } 57 \text { years; } 60 \% \text { male. Mean FEV } 160 \% \\
\text { predicted. } 18 \text { dropped out }\end{array}$ \\
\hline Interventions & NAC $600 \mathrm{mg}$ daily or placebo \\
\hline Outcomes & $\begin{array}{l}\text { Exacerbations, severity of exacerbations, time to first exacerbation, days sick, lung function, partici- } \\
\text { pant symptoms, adverse effects }\end{array}$ \\
\hline Notes & $\begin{array}{l}\text { European. COPD, not chronic bronchitis. BREATHE study. Published in abstract form only. Zambon pro- } \\
\text { vided more information. Study never published in full }\end{array}$
\end{tabular}

\section{Risk of bias}

\begin{tabular}{|c|c|c|}
\hline Bias & Authors' judgement & Support for judgement \\
\hline $\begin{array}{l}\text { Random sequence genera- } \\
\text { tion (selection bias) }\end{array}$ & Unclear risk & Information not available \\
\hline $\begin{array}{l}\text { Allocation concealment } \\
\text { (selection bias) }\end{array}$ & Unclear risk & Information not available \\
\hline $\begin{array}{l}\text { Blinding of participants } \\
\text { and personnel (perfor- } \\
\text { mance bias) } \\
\text { All outcomes }\end{array}$ & Low risk & Double-blind \\
\hline $\begin{array}{l}\text { Blinding of outcome as- } \\
\text { sessment (detection bias) } \\
\text { All outcomes }\end{array}$ & Low risk & Double-blind \\
\hline $\begin{array}{l}\text { Incomplete outcome data } \\
\text { (attrition bias) } \\
\text { All outcomes }\end{array}$ & Low risk & $\begin{array}{l}12 / 159(8 \%) \text { dropped out of the intervention arm and } 6 / 154(4 \%) \text { dropped out } \\
\text { of the placebo arm. Reasons for dropout not reported, but overall low rate of } \\
\text { attrition }\end{array}$ \\
\hline $\begin{array}{l}\text { Selective reporting (re- } \\
\text { porting bias) }\end{array}$ & High risk & Information not available \\
\hline
\end{tabular}


Olivieri 1987

$\begin{array}{ll}\text { Methods } & \begin{array}{l}\text { Randomised, double-blind, placebo-controlled, parallel, multi-centre (13). PP analysis. Duration } 6 \\ \text { months }\end{array}\end{array}$
months

\section{Participants}

240 outpatients with chronic bronchitis defined by MRC. At least 3 exacerbations in previous year or pathological auscultatory assessment or reduction of $15 \%$ to $40 \%$ in $\mathrm{FEV}_{1}$. Exclusions: patients with asthma, $\mathrm{FEV}_{1}<40 \%$ predicted, peptic ulcer or other serious comorbidity, pregnancy, long-term antibiotics or mucolytics. 26 dropped out

\begin{tabular}{ll} 
Interventions & Ambroxol retard $75 \mathrm{mg}$ or placebo daily \\
\hline Outcomes & $\begin{array}{l}\text { Exacerbations, courses of antibiotics, days sick, } \mathrm{FEV}_{1}, \mathrm{VC}, \text { symptoms, auscultatory findings, physician } \\
\text { and participant global assessments, laboratory data, adverse effects }\end{array}$ \\
\hline Notes & $\begin{array}{l}\text { Italian. We suspect that what is reported as SD in the paper is in fact SE (using t statistic and P values). } \\
\text { We wrote to study authors for clarification. We received no reply }\end{array}$
\end{tabular}

\section{Risk of bias}

\begin{tabular}{|c|c|c|}
\hline Bias & Authors' judgement & Support for judgement \\
\hline $\begin{array}{l}\text { Random sequence genera- } \\
\text { tion (selection bias) }\end{array}$ & Low risk & Computer-randomised \\
\hline $\begin{array}{l}\text { Allocation concealment } \\
\text { (selection bias) }\end{array}$ & Unclear risk & Each centre provided with a list \\
\hline $\begin{array}{l}\text { Blinding of participants } \\
\text { and personnel (perfor- } \\
\text { mance bias) } \\
\text { All outcomes }\end{array}$ & Low risk & Double-blind \\
\hline $\begin{array}{l}\text { Blinding of outcome as- } \\
\text { sessment (detection bias) } \\
\text { All outcomes }\end{array}$ & Low risk & Double-blind \\
\hline $\begin{array}{l}\text { Incomplete outcome data } \\
\text { (attrition bias) } \\
\text { All outcomes }\end{array}$ & Unclear risk & $\begin{array}{l}11 / 121 \text { ( } 9 \%) \text { dropped out of the intervention arm and } 15 / 119 \text { ( } 13 \%) \text { dropped } \\
\text { out of the placebo arm. More participants in the placebo group "failed to re- } \\
\text { turn" ( } 9 \text { vs } 3 \text { ) or experienced "inefficacy" ( } 3 \text { vs } 1 \text { ) or an adverse reaction leading } \\
\text { to withdrawal ( } 2 \text { vs } 0) \text {. More participants in the intervention group withdrew } \\
\text { due to "poor collaboration" ( } 2 \text { vs } 0 \text { ) or leaving the department ( } 3 \text { vs } 1 \text { ) }\end{array}$ \\
\hline $\begin{array}{l}\text { Selective reporting (re- } \\
\text { porting bias) }\end{array}$ & Low risk & PP and ITT analyses of all main outcomes \\
\hline
\end{tabular}

\section{Parr 1987}

\begin{tabular}{ll}
\hline Methods & Randomised, double-blind, placebo-controlled, parallel, multi-centre. PP analysis. Duration 6 months \\
\hline Participants & 526 general practice patients with chronic bronchitis defined by MRC, with at least 1 exacerbation in \\
& past 12 months. Exclusions: other significant respiratory disease, active peptic ulceration, severe heart \\
& failure, continuous therapy with antibiotics or mucolytics. 204 dropouts. Mean age 63 years; $66 \%$ male; \\
& $86 \%$ had smoked
\end{tabular}


Parr 1987 (Continued)

Outcomes Exacerbations, days off work, adverse effects

Notes British. Pharmaceutical company trial. Large number of dropouts, although seemed matched. SD calculated from raw data in paper. More data needed to calculate days sick

\section{Risk of bias}

\begin{tabular}{|c|c|c|}
\hline Bias & Authors' judgement & Support for judgement \\
\hline $\begin{array}{l}\text { Random sequence genera- } \\
\text { tion (selection bias) }\end{array}$ & Low risk & Randomly assigned in blocks of 4 \\
\hline $\begin{array}{l}\text { Allocation concealment } \\
\text { (selection bias) }\end{array}$ & Unclear risk & Information not available \\
\hline $\begin{array}{l}\text { Blinding of participants } \\
\text { and personnel (perfor- } \\
\text { mance bias) } \\
\text { All outcomes }\end{array}$ & Low risk & Double-blind; interventions identical \\
\hline $\begin{array}{l}\text { Blinding of outcome as- } \\
\text { sessment (detection bias) } \\
\text { All outcomes }\end{array}$ & Low risk & Double-blind \\
\hline $\begin{array}{l}\text { Incomplete outcome data } \\
\text { (attrition bias) } \\
\text { All outcomes }\end{array}$ & High risk & $\begin{array}{l}204 / 526 \text { ( } 39 \%) \text { did not complete all follow-up over the 6-month follow up pe- } \\
\text { riod. } 49 \text { missed } 1 \text { or more assessment but were subsequently followed up. } \\
\text { Two participants remained lost to follow-up. } 153 \text { dropped out; } 79 / 258 \text { ( } 31 \%) \\
\text { dropped out of the intervention group and } 75 / 268 \text { ( } 28 \% \text { ) dropped out of the } \\
\text { placebo group. Reasons for dropout were reasonably balanced, although more } \\
\text { participants withdrew from the intervention arm due to "lack of efficacy" ( } 15 \\
\text { vs 6) }\end{array}$ \\
\hline $\begin{array}{l}\text { Selective reporting (re- } \\
\text { porting bias) }\end{array}$ & Unclear risk & No specific outcomes stated \\
\hline
\end{tabular}

Pela 1999

\begin{tabular}{ll}
\hline Methods & Randomised, open, placebo-controlled, parallel, multi-centre (5). Duration 6 months. PP analysis \\
\hline Participants & 169 outpatients with COPD (defined by ATS and ERS); aged 40 to 75 years; FEV $<$ < $70 \%$ predicted; re- \\
& $\begin{array}{l}\text { versibility }<12 \% \text { Exclusions: lung cancer, cardiomyopathy, metabolic disease, renal failure, other se- } \\
\text { vere disease. Mean age } 66 \text { years; } 76 \% \text { male; mean FEV } 1 \text { 1.49 L; } 58 \% \text { predicted; } 28 \% \text { current smokers. } 6 \\
\text { dropped out }\end{array}$
\end{tabular}

Interventions NAC 600 mg daily or placebo

\begin{tabular}{ll}
\hline Outcomes & Exacerbations, exacerbation severity, days sick, participant preference, lung function \\
\hline Notes & Italian study. Open study. COPD, not chronic bronchitis
\end{tabular}

\section{Risk of bias}

Bias Authors' judgement Support for judgement


Pela 1999 (Continued)

Random sequence genera- Unclear risk $\quad$ No details
tion (selection bias)

tion (selection bias)

Allocation concealment High risk Investigators aware of order of allocation
(selection bias)

Blinding of participants High risk $\quad$ Open study
and personnel (perfor-
mance bias)
All outcomes

\begin{tabular}{lll}
\hline $\begin{array}{l}\text { Blinding of outcome as- } \\
\text { sessment (detection bias) } \\
\text { All outcomes }\end{array}$ & High risk & Open study \\
\hline $\begin{array}{l}\text { Incomplete outcome data } \\
\text { (attrition bias) }\end{array}$ & Unclear risk & $\begin{array}{l}2 / 85(2 \%) \text { dropped out of the intervention group and 4/84 (5\%) from the stan- } \\
\text { dard care group. Reasons were balanced }\end{array}$ \\
\hline $\begin{array}{l}\text { Sell outcomes } \\
\text { porting bias) }\end{array}$ & Low risk & Reported on main outcomes \\
\hline
\end{tabular}

Petty 1990

\begin{tabular}{ll}
\hline Methods & Randomised, double-blind, placebo-controlled, parallel, multi-centre. Duration 2 months. ITT analysis \\
\hline Participants & 367 outpatients with stable chronic bronchitis defined by ATS were randomly assigned. Required pre- \\
& bronchodilator $\mathrm{FEV}_{1}<75 \%$ predicted. 79 dropouts ( 33 in mucolytic group and 46 in placebo group). \\
& Mean age 65 years; $70 \%$ male; mean $\mathrm{FEV}_{1} 44.5 \%$ predicted. Exclusions: pregnant or lactating, allergic \\
& to iodine, comorbidity that would confound response or compliance, asthma, exacerbation in past \\
month, using antibiotics or anticholinergics
\end{tabular}

\begin{tabular}{ll}
\hline Interventions & lodinated glycerol $30 \mathrm{mg}, 2$ tabs 4 times a day, or identical-looking placebo \\
\hline Outcomes & $\begin{array}{l}\text { Investigator assessment of symptoms; participant evaluation of symptoms; global assessment at } \\
\text { weeks } 0,4 \text {, and } 8 ; \text { frequency of bronchodilator use; number and duration of acute exacerbations; fre- } \\
\text { quency of concomitant medications; adverse experiences Dropouts assessed at weeks } 4 \text { and } 8\end{array}$ \\
\hline Notes & $\begin{array}{l}\text { American. Requested more information from study author, but study author was unable to provide. } \\
\text { Pharmaceutical company (Wallace) approached. No reply. No significant differences (reported) be- } \\
\text { tween groups in exacerbation rates; however, significantly fewer days sick in treatment group. We esti- } \\
\text { mated sample SD from t statistic and pooled t formula and assumed equal variances to arrive at an es- } \\
\text { timate for SD of } 18.8\end{array}$ \\
\hline
\end{tabular}

\section{Risk of bias}

\begin{tabular}{lll}
\hline Bias & Authors' judgement & Support for judgement \\
\hline $\begin{array}{l}\text { Random sequence genera- } \\
\text { tion (selection bias) }\end{array}$ & Low risk & Computer-generated \\
\hline $\begin{array}{l}\text { Allocation concealment } \\
\text { (selection bias) }\end{array}$ & Unclear risk & Information not available \\
\hline
\end{tabular}


Petty 1990 (Continued)

Blinding of participants Low risk Double-blind; matched placebo and personnel (performance bias)

All outcomes

\begin{tabular}{lll}
\hline $\begin{array}{l}\text { Blinding of outcome as- } \\
\text { sessment (detection bias) } \\
\text { All outcomes }\end{array}$ & Low risk & Double-blind \\
\hline $\begin{array}{l}\text { Incomplete outcome data } \\
\text { (attrition bias) }\end{array}$ & High risk & $\begin{array}{l}35 / 182(19 \%) \text { dropped out of the intervention arm and } 50 / 185(27 \%) \text { from the } \\
\text { placebo arm. Reasons were relatively balanced, with the exception of with- } \\
\text { drawals due to adverse events (10 in the intervention group vs } 24 \text { in the place- } \\
\text { bo group), which accounts for the imbalance in numbers }\end{array}$ \\
\hline
\end{tabular}

Selective reporting (re- Low risk None detected

porting bias)

\section{Rasmussen 1988}

\begin{tabular}{ll}
\hline Methods & $\begin{array}{l}\text { Randomised, double-blind, placebo-controlled, parallel, multi-centre (9). PP analysis. Duration } 6 \\
\text { months }\end{array}$ \\
\hline Participants & $\begin{array}{l}116 \text { outpatients with chronic bronchitis defined by MRC. At least } 1 \text { exacerbation previous winter. } 100 \% \\
\text { had smoked. Mean age } 58.9 \text { years; } 57 \% \text { male; average PEFR } 305 \text { L/min. } 25 \text { dropped out }\end{array}$ \\
\hline Interventions & NAC 300 mg twice daily or placebo \\
\hline Outcomes & Exacerbations, days sick evaluated by days on sick list and by participant diaries, adverse effects \\
\hline Notes & Swedish
\end{tabular}

\section{Risk of bias}

\begin{tabular}{|c|c|c|}
\hline Bias & Authors' judgement & Support for judgement \\
\hline $\begin{array}{l}\text { Random sequence genera- } \\
\text { tion (selection bias) }\end{array}$ & Low risk & Randomisation in blocks of 4 \\
\hline $\begin{array}{l}\text { Allocation concealment } \\
\text { (selection bias) }\end{array}$ & Unclear risk & Information not available \\
\hline $\begin{array}{l}\text { Blinding of participants } \\
\text { and personnel (perfor- } \\
\text { mance bias) } \\
\text { All outcomes }\end{array}$ & Low risk & Double-blind \\
\hline $\begin{array}{l}\text { Blinding of outcome as- } \\
\text { sessment (detection bias) } \\
\text { All outcomes }\end{array}$ & Unclear risk & Double-blind \\
\hline $\begin{array}{l}\text { Incomplete outcome data } \\
\text { (attrition bias) } \\
\text { All outcomes }\end{array}$ & Unclear risk & $\begin{array}{l}15 / 59(25 \%) \text { dropped out of the intervention group and } 10 / 57(18 \%) \text { from the } \\
\text { placebo group. Reasons were reasonably balanced between arms }\end{array}$ \\
\hline
\end{tabular}


Rasmussen 1988 (Continued)

Selective reporting (re- Low risk $\quad$ Main outcomes reported
porting bias)

Roy 2014

Methods Randomised, single-blind, placebo-controlled, parallel, single-centre. PP analysis. Duration 6 months

Followed up every month

Participants $\quad 80$ outpatients age $>40$, stable mild to moderate COPD, smoking history at least 10 pack-years. Exclusions: those with asthma, lung cancer, cardiomyopathy, LVRS or transplant, or on LTOT or corticosteroids. Mean age $61 ; 89 \%$ male. Total 20 dropouts, evenly matched between groups

Interventions NAC 600 mg twice daily or placebo. Both groups received a bronchodilator Deriphylline Retard 150 mg
in addition

\begin{tabular}{ll}
\hline Outcomes & Symptoms (cough, dyspnoea, sputum), spirometry, Hb, adverse events \\
\hline Notes & Indian \\
& Funding source not reported \\
\hline
\end{tabular}

\section{Risk of bias}

\begin{tabular}{lll}
\hline Bias & Authors' judgement & Support for judgement \\
\hline $\begin{array}{l}\text { Random sequence genera- } \\
\text { tion (selection bias) }\end{array}$ & High risk & No details on this, except it was a "simple method" \\
\hline $\begin{array}{l}\text { Allocation concealment } \\
\text { (selection bias) }\end{array}$ & High risk & Single-blind study; few details on allocation or concealment of sequence given
\end{tabular}

\begin{tabular}{|c|c|c|}
\hline $\begin{array}{l}\text { Blinding of participants } \\
\text { and personnel (perfor- } \\
\text { mance bias) } \\
\text { All outcomes }\end{array}$ & High risk & $\begin{array}{l}\text { No details on match between placebo and NAC, or on who performed mea- } \\
\text { surements; sIngle-blind }\end{array}$ \\
\hline $\begin{array}{l}\text { Blinding of outcome as- } \\
\text { sessment (detection bias) } \\
\text { All outcomes }\end{array}$ & High risk & SIngle-blind study \\
\hline $\begin{array}{l}\text { Incomplete outcome data } \\
\text { (attrition bias) } \\
\text { All outcomes }\end{array}$ & High risk & $25 \%$ dropout rate $(20 / 80)$; numbers and reasons per arm not given \\
\hline $\begin{array}{l}\text { Selective reporting (re- } \\
\text { porting bias) }\end{array}$ & Unclear risk & Spirometric data reported in units that read "total count" \\
\hline
\end{tabular}

\section{Schermer 2009}

\begin{tabular}{ll}
\hline Methods & Randomised, double-blind, placebo-controlled, parallel, multi-centre (44 general practices). Duration 3 \\
years. ITT and PP analyses
\end{tabular}


Schermer 2009 (Continued)

Participants

192 (in study arms NAC and placebo, each $n=96$ ) GP outpatients with chronic bronchitis or stable COPD between ages of 35 and 75 . Current or former smokers with chronic dyspnoea, sputum, and cough for at least 3 consecutive months in previous 2 years; post-bronchodilator $\mathrm{FEV}_{1}<90 \%$ and/or post-bronchodilator $\mathrm{FEV}_{1} / \mathrm{FVC}$ ratio $<0.88$ for men and $<0.89$ for women Exclusions: $\mathrm{FEV}_{1} / \mathrm{FVC}$ ratio $<$ 0.4 and/or history of asthma, allergic rhinitis, or eczema

84 dropouts (44 in mucolytic group and 40 in placebo group). Mean age 59 years; $73 \%$ male. Mean postbronchodilator FEV $12.15 \mathrm{~L}$ (62\% predicted). 53\% were still smoking. $22 \%$ had chronic bronchitis with no obstruction: $14 \%$ mild, $47 \%$ moderate, and 17\% severe COPD. Mean CRQ score 4.84 ; baseline exacerbation rate mean 0.88 per year/median 0.5

Participants well matched at baseline. High dropout rate. Generally low exacerbation rates, except small number of participants who experienced very frequent exacerbations

Interventions

3 arms, double-dummy (tablet and inhaler). NAC $600 \mathrm{mg}$ effervescent tablet daily vs fluticasone $500 \mu \mathrm{g}$ twice daily vs placebo. This review included only NAC vs placebo arms. 2 weeks of pretreatment with prednisone $30 \mathrm{mg}$ daily

\section{Outcomes} Primary outcomes: rates of exacerbation and disease-specific quality of life, as measured by CRQ

Other outcomes: lung function, hospitalisation

Notes Netherlands

\section{Risk of bias}

\begin{tabular}{|c|c|c|}
\hline Bias & Authors' judgement & Support for judgement \\
\hline $\begin{array}{l}\text { Random sequence genera- } \\
\text { tion (selection bias) }\end{array}$ & Low risk & List generated by independent statistician \\
\hline $\begin{array}{l}\text { Allocation concealment } \\
\text { (selection bias) }\end{array}$ & Low risk & Neither participants nor investigators aware of allocation \\
\hline $\begin{array}{l}\text { Blinding of participants } \\
\text { and personnel (perfor- } \\
\text { mance bias) } \\
\text { All outcomes }\end{array}$ & Low risk & Double-dummy study \\
\hline $\begin{array}{l}\text { Blinding of outcome as- } \\
\text { sessment (detection bias) } \\
\text { All outcomes }\end{array}$ & Low risk & Double-dummy \\
\hline $\begin{array}{l}\text { Incomplete outcome data } \\
\text { (attrition bias) } \\
\text { All outcomes }\end{array}$ & High risk & $\begin{array}{l}44 \% \text { dropout rate ( } 44 / 96 \text { and } 40 / 97 \text { dropped out on mucolytics and placebo, } \\
\text { respectively). Reasons and numbers are balanced but high rate overall leads to } \\
\text { judgement of high risk }\end{array}$ \\
\hline $\begin{array}{l}\text { Selective reporting (re- } \\
\text { porting bias) }\end{array}$ & Low risk & None detected \\
\hline
\end{tabular}

Tse 2013

Randomised, double-blind, placebo-controlled, parallel. 1 hospital centre. Duration 1 year
4-week run-in period; randomisation, then follow-up at 16, 32, and 48 weeks
Analysis ITT


Tse 2013 (Continued)

Participants $\quad 133$ outpatients aged 50 to 80 with stable COPD (FEV $/ F V C<0.7)$ recruited, 120 randomised. Exclusions: co-existent pulmonary disease, LTOT, BiPAP, severe dyspnoea, poor reliability or compliance. Mean age $71 ; 93 \%$ male; $23 \%$ current smokers

$18 \%$ GOLD 1, 40\% GOLD 2, 34\% GOLD 3, 8\% GOLD 4. Median of 2 exacerbations in past year. Groups well matched at baseline. 12 dropouts -6 in each group

\begin{tabular}{ll}
\hline Interventions & NAC 600 mg twice daily or placebo \\
\hline Outcomes & Primary: small airways parameters $\mathrm{FEF}_{25 \%-75 \%}, \mathrm{FOT}$, IC, spirometry \\
& Secondary: exacerbation rate, mMRC dyspnoea scale, SGRQ, 6MWD \\
\hline Notes & Chinese (Hong Kong). HIACE study. Funded by pharmaceutical company \\
& $\begin{array}{l}\text { Funding from local hospital research fund. Zambon provided NAC and placebo. } 1 \text { study author (Dr } \\
\text { Ratieri) employed by Zambon }\end{array}$ \\
\hline
\end{tabular}

\section{Risk of bias}

\begin{tabular}{|c|c|c|}
\hline Bias & Authors' judgement & Support for judgement \\
\hline $\begin{array}{l}\text { Random sequence genera- } \\
\text { tion (selection bias) }\end{array}$ & Unclear risk & No detail on this \\
\hline $\begin{array}{l}\text { Allocation concealment } \\
\text { (selection bias) }\end{array}$ & Unclear risk & $\begin{array}{l}\text { Not well described: "randomisation and allocation details known only to a } \\
\text { third party" }\end{array}$ \\
\hline $\begin{array}{l}\text { Blinding of participants } \\
\text { and personnel (perfor- } \\
\text { mance bias) } \\
\text { All outcomes }\end{array}$ & Low risk & $\begin{array}{l}\text { NAC and placebo "identical in appearance"; "patients and investigators blind- } \\
\text { ed to treatment allocation during the study". Compliance assessed }\end{array}$ \\
\hline $\begin{array}{l}\text { Blinding of outcome as- } \\
\text { sessment (detection bias) } \\
\text { All outcomes }\end{array}$ & Low risk & "Patients and investigators blinded to treatment allocation during the study" \\
\hline $\begin{array}{l}\text { Incomplete outcome data } \\
\text { (attrition bias) } \\
\text { All outcomes }\end{array}$ & Low risk & $\begin{array}{l}10 \% \text { dropout rate }(12 / 120) \text { after randomisation. Flow chart of dropout num- } \\
\text { bers provided and reasons relatively balanced }\end{array}$ \\
\hline $\begin{array}{l}\text { Selective reporting (re- } \\
\text { porting bias) }\end{array}$ & Low risk & All major outcomes reported in detail \\
\hline
\end{tabular}

\section{Worth 2009}

\begin{tabular}{ll}
\hline Methods & $\begin{array}{l}\text { Randomised, double-blind, placebo-controlled, parallel, multi-centre (11 centres; } 4 \text { GPs and } 7 \text { special- } \\
\text { ists). ITT analysis } \\
\text { Duration } 6 \text { months over winter }\end{array}$ \\
\hline Participants & $\begin{array}{l}220 \text { outpatients aged } 40 \text { to } 80 \text { with moderate or severe COPD defined by GOLD. } 30 \%>\mathrm{FEV},<70 \%, \text { with } \\
\text { reversibility below } 15 \% \text {. All were smokers or ex-smokers. Mean age } 62.3 \text { years; } 64 \% \text { were male. Mean } \\
\text { FEV } 1.61 \mathrm{~L}(54.7 \% \text { predicted). Exclusions: severe medical conditions such as bronchial carcinoma, MI, } \\
\text { alcoholism, or heart failure. Unclear how many participants finished the study } \\
\text { Groups well matched at baseline. Compliance said to be 'good' in all participants }\end{array}$ \\
\hline
\end{tabular}


Worth 2009 (Continued)

\begin{tabular}{ll} 
Interventions & Cineole $2 \times 100 \mathrm{mg} 3$ times daily (total $600 \mathrm{mg}$ ) or placebo \\
\hline Outcomes & Primary outcome: exacerbations - number, severity, duration \\
& Secondary outcomes: lung function, dyspnoea, quality of life (SGRQ), adverse effects \\
& Primary outcomes, dyspnoea, and adverse effects assessed at each visit. Lung function assessed at 0,3, \\
& and 6 months. Quality of life assessed at 0 and 6 months \\
\hline Notes & German
\end{tabular}

\section{Risk of bias}

\begin{tabular}{|c|c|c|}
\hline Bias & Authors' judgement & Support for judgement \\
\hline $\begin{array}{l}\text { Random sequence genera- } \\
\text { tion (selection bias) }\end{array}$ & Unclear risk & $\begin{array}{l}\text { Apart from an indication of stratification by site, no details given on randomi- } \\
\text { sation methods }\end{array}$ \\
\hline $\begin{array}{l}\text { Allocation concealment } \\
\text { (selection bias) }\end{array}$ & Unclear risk & No details \\
\hline $\begin{array}{l}\text { Blinding of participants } \\
\text { and personnel (perfor- } \\
\text { mance bias) } \\
\text { All outcomes }\end{array}$ & High risk & $\begin{array}{l}\text { Participants instructed to take medication a half hour before meals to avoid } \\
\text { the smell of cineole. Active and placebo capsules looked identical }\end{array}$ \\
\hline $\begin{array}{l}\text { Blinding of outcome as- } \\
\text { sessment (detection bias) } \\
\text { All outcomes }\end{array}$ & Unclear risk & No details \\
\hline $\begin{array}{l}\text { Incomplete outcome data } \\
\text { (attrition bias) } \\
\text { All outcomes }\end{array}$ & Unclear risk & No details on dropouts \\
\hline $\begin{array}{l}\text { Selective reporting (re- } \\
\text { porting bias) }\end{array}$ & Low risk & None apparent \\
\hline
\end{tabular}

Xu 2014

\begin{tabular}{|c|c|}
\hline Methods & Randomised, double-blind, placebo-controlled, parallel. Duration 6 months \\
\hline \multirow[t]{3}{*}{ Participants } & $\begin{array}{l}84 \text { outpatients over } 20 \text { years of age with chronic bronchitis as defined by the MRC, or COPD as defined } \\
\text { by criteria of the ATS, GOLD, ERS, or WHO }\end{array}$ \\
\hline & Exclusion criteria: not known \\
\hline & Dropouts: no dropouts in either arm \\
\hline Interventions & NAC $600 \mathrm{mg}$ twice daily or salmeterol/fluticasone propionate alone \\
\hline Outcomes & $\begin{array}{l}\mathrm{FEV} \\
1 / F V C, \mathrm{FEV}_{1} \% \text { predicted, } \mathrm{PEF} \% \text { daily variation change, arterial blood gas analysis index }\left(\mathrm{PaO}_{2} \text { and }\right. \\
\left.\mathrm{PaCO}_{2}\right)\end{array}$ \\
\hline Notes & Study published in Chinese. Funded by Jilin provincial science and technology department \\
\hline
\end{tabular}

\section{Risk of bias}


Xu 2014 (Continued)

\section{Bias Authors' judgement Support for judgement}

Random sequence genera- Unclear risk Described as "randomised"; no other details

tion (selection bias)

Allocation concealment $\quad$ Unclear risk $\quad$ No details
(selection bias)

Blinding of participants High risk $\quad$ No description of placebo or blinding; assume open-label
and personnel (perfor-
mance bias)
All outcomes

Blinding of outcome as- Unclear risk No description of placebo or blinding; assume open-label sessment (detection bias)

All outcomes

Incomplete outcome data Low risk No dropouts
(attrition bias)
All outcomes

\begin{tabular}{|c|c|c|}
\hline $\begin{array}{l}\text { Selective reporting (re- } \\
\text { porting bias) }\end{array}$ & Unclear risk & $\begin{array}{l}\text { All stated outcomes of interest to this review reported numerically, but no } \\
\text { published protocol or trial registration identified }\end{array}$ \\
\hline
\end{tabular}

\section{Zheng 2008}

$\begin{array}{ll}\text { Methods } & \begin{array}{l}\text { Randomised, double-blind, placebo-controlled, parallel, multi-centre (22 centres). Duration } 1 \text { year. ITT } \\ \text { analysis }\end{array}\end{array}$

\section{Participants}

709 outpatients with stable COPD defined by GOLD criteria with post-bronchodilator $\mathrm{FEV}_{1} / \mathrm{FVC}_{\text {ratio }}<$ 0.7 and $\mathrm{FEV}_{1}$ between $25 \%$ and $79 \%$ predicted. Patients between ages of 40 and 80 with history of at least 2 COPD exacerbations in previous 2 years. Clinically stable in past 4 weeks. 91 dropouts (48 in mucolytic group and 43 in placebo group). Mean age 65 years; $78 \%$ male; mean FEV 1.09 L (44.5\% predicted). $75 \%$ had ever smoked. $49 \%$ were GOLD 2, 39\% GOLD 3, and $12 \%$ GOLD 4. Mean SGRQ was 42 . Exclusions: asthma, non-COPD respiratory disorders, LVRS or transplant or other conditions that would interfere with the study, those on LTOT or pulmonary rehabilitation or on OCS, pregnancy or lactating. Patients involved in another investigational drug trial in past 12 weeks were also excluded

$18 \%$ of intervention group and $15 \%$ of placebo group were on ICS

\begin{tabular}{ll}
\hline Interventions & Carbocysteine $1500 \mathrm{mg}$ daily $(2 \times 250 \mathrm{mg} 3$ times daily) orally or placebo \\
\hline Outcomes & Primary endpoint: exacerbation rate (defined by Anthonisen) \\
& $\begin{array}{l}\text { Secondary endpoints: co-variance-adjusted exacerbation rate, quality of life (SGRQ), lung function, ar- } \\
\text { terial oxygen saturation }\end{array}$ \\
\hline Notes & Chinese. Main PEACE study. Financial support from Kyron Pharmaceutical, Japan \\
& $\begin{array}{l}\text { Lancet report for main PEACE study describes } 709 \text { participants from } 22 \text { centres in China. Another } 2 \text { ref- } \\
\text { erences to PEACE study from Japan (Tatsumi } 2007 \text {; Tatsumi } 2007 \mathrm{~b}) . \text { Both refer to same sample of } 142 \\
\text { patients - } 70 \text { in control group and } 72 \text { in study group. Have written to Dr Zhong to ask if a substudy of } \\
\text { main PEACE study was a different study }\end{array}$
\end{tabular}

\section{Risk of bias}


Zheng 2008 (Continued)

\begin{tabular}{lll} 
Bias & Authors' judgement & Support for judgement \\
\hline $\begin{array}{l}\text { Random sequence genera- } \\
\text { tion (selection bias) }\end{array}$ & Low risk & "Computer-generated randomisation list" \\
\hline $\begin{array}{l}\text { Allocation concealment } \\
\text { (selection bias) }\end{array}$ & Low risk & "Neither the investigator nor the patient knew the group allocation" \\
\hline $\begin{array}{l}\text { Blinding of participants } \\
\text { and personnel (perfor- } \\
\text { mance bias) }\end{array}$ & Low risk & "The placebo was identical to the drug in appearance labelling and packaging" \\
All outcomes & &
\end{tabular}

Blinding of outcome as- Low risk Statistical analysis done without awareness of treatment allocation
sessment (detection bias)

All outcomes

\begin{tabular}{|c|c|c|}
\hline $\begin{array}{l}\text { Incomplete outcome data } \\
\text { (attrition bias) } \\
\text { All outcomes }\end{array}$ & Unclear risk & $\begin{array}{l}13 \% \text { dropout rate ( } 48 / 353 \text { and } 43 / 354 \text { withdrew from mucolytics and place- } \\
\text { bo, respectively). Some imbalance noted in the reasons for dropout; a greater } \\
\text { number of intervention participants dropped out due to "no compliance or } \\
\text { lack of consent" ( } 30 \text { vs } 16) \text {, whereas more placebo participants were lost to fol- } \\
\text { low-up ( } 21 \text { vs } 10) \text {. Analyses performed on an intention-to-treat basis }\end{array}$ \\
\hline
\end{tabular}

Selective reporting (re- Low risk None apparent
porting bias)

\section{Zheng 2014}

Methods

Randomised, double-blind, placebo-controlled, parallel, multi-centre (34 centres). Duration 1 year

2 week run-in period; then randomisation and visits at 1, 2, 6, 9, and 12 months. Analysis conducted on "patients who received at one dose of study drug, and had at least one visit assessment after randomisation"

This ended up being 482 in each group (total 964). Completers totaled 763. Methods for handling missing data not outlined

Participants

From 1297 screened, investigators enrolled 1006 outpatients aged 40 to 80 with moderate to severe COPD ( $\mathrm{FEV}_{1}<30 \%$ to $70 \%$ predicted and ratio $<0.7$ ). These were stratified by previous regular use of ICS at baseline (500 to $2000 \mu \mathrm{g} /$ day of beclomethasone or equivalent). Exclusions: bronchial asthma, LTOT $\geq 12$ hours per day or pulmonary rehabilitation, major comorbidity, poor reliability or compliance. Ratio of ICS users to ICS naïve participants was set at about 4:6

Groups were well matched at baseline. Mean age 66 years; $82 \%$ male; $76 \%$ ever smokers; mean FEV $49 \%$ predicted. $46 \%$ GOLD 2, 53\% GOLD 3, and 1\% GOLD 4.243 dropouts - 124 in treatment group and 119 in placebo group - with main reasons being loss to follow-up and adverse events. Provided analysis of dropouts ( $N=243$ ) vs completers $(N=763)$ - similar among the 2 groups

\begin{tabular}{ll} 
Interventions & NAC 600 mg twice daily or placebo \\
\hline Outcomes & Primary: exacerbation rate in 1 year, exacerbation duration \\
& $\begin{array}{l}\text { Secondary: time to first exacerbation, time to recurrent exacerbation, number of participants requir- } \\
\text { ing systemic corticosteroids or antibiotics or use of SABA rescue medication, SGRQ (Chinese version), } \\
\text { spirometry, adverse events (including hospitalisation or death) }\end{array}$
\end{tabular}


Zheng 2014 (Continued)

Notes

Chinese. PANTHEON study. Funded by a pharmaceutical company (Hainan Zambon Pharmaceutical). Study authors had full access to all data and were involved in data interpretation and preparation of manuscript in collaboration with sponsor. Corresponding authors had final responsibility for decision to submit for publication

Dr Zheng provided Appendix, as well as further data on exacerbation rates, SQRG scores, and spirometry

\section{Risk of bias}

\begin{tabular}{lll}
\hline Bias & Authors' judgement & Support for judgement \\
\hline $\begin{array}{ll}\text { Random sequence genera- } \\
\text { tion (selection bias) }\end{array}$ & Low risk & $\begin{array}{l}\text { Stratified randomisation conducted using a pre-determined computer-gen- } \\
\text { erated randomisation list provided by a statistician from a third party not in- } \\
\text { volved in the study. This third party was exclusively responsible for randomisa- } \\
\text { tion, data management, data analysis, and data quality control }\end{array}$ \\
\hline
\end{tabular}

\begin{tabular}{ll}
$\begin{array}{l}\text { Allocation concealment } \quad \text { Low risk } \\
\text { (selection bias) }\end{array}$ & $\begin{array}{l}\text { Supplies of tablets for every participant were identified by a 4-digit number. A } \\
\text { sealed envelope containing the randomisation code for each participant was } \\
\text { kept by the investigator and was not to be opened during the study, unless a } \\
\text { serious life-threatening adverse event occurred }\end{array}$ \\
\hline
\end{tabular}

$\begin{array}{ll}\begin{array}{l}\text { Blinding of participants } \\ \text { and personnel (perfor- }\end{array} & \text { Low risk } \\ \begin{array}{ll}\text { mance bias) } & \text { Both NAC and placebo tablets were provided by Hainan Zambon Pharmaceu- } \\ \text { All outcomes } & \text { tical Co., Ltd. The placebo was identical in composition, shape, colour, and } \\ & \text { size but did not contain any active ingredients. NAC and placebo tablets were } \\ \text { packaged and labelled in such a way that they could not be distinguished from } \\ \text { each other }\end{array}\end{array}$

\begin{tabular}{|c|c|c|}
\hline $\begin{array}{l}\text { Blinding of outcome as- } \\
\text { sessment (detection bias) } \\
\text { All outcomes }\end{array}$ & Low risk & $\begin{array}{l}\text { All investigators were trained before the trial to ensure reliable study quality, } \\
\text { with special emphasis on understanding the protocol, performing spirometry } \\
\text { tests, blinding to allocation, managing the drug supply, and maintaining com- } \\
\text { pliance with Good Clinical Practice (GCP). Details of study design were pub- } \\
\text { lished ahead of the study results }\end{array}$ \\
\hline
\end{tabular}

Incomplete outcome data High risk 24\% dropout rate (243/1006); 124/504 (25\%) in the intervention group and (attrition bias) $\quad 119 / 502(24 \%)$ in the placebo group. Some imbalance noted in the reasons for All outcomes withdrawal; in the intervention group, more participants withdrew due to adverse events (32 vs 24), whereas in the placebo group, more participants were lost to follow-up (56 vs 48) and withdrew due to lack of efficacy 21 vs 17)

\begin{tabular}{l}
$\begin{array}{l}\text { Selective reporting (re- Low risk CONSORT statement was followed to ensure proper reporting of this study } \\
\text { porting bias) }\end{array}$ \\
\hline
\end{tabular}

6MWD: six-minute walk distance; ABG: arterial blood gas; ATS: American Thoracic Society; BiPAP: bi-level non-invasive ventilation; BTS: British Thoracic Society; CBSAS: Chronic Bronchitis Symptoms Assessment Scale; CF: cystic fibrosis; COPD: chronic obstructive pulmonary

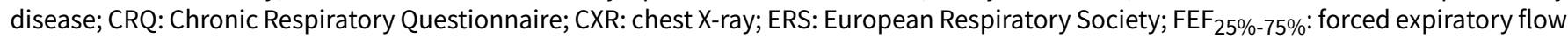
at $25-75 \%$ of the pulmonary volume; $\mathrm{FEV}_{1}$ : forced expiratory volume in one second; FOT: forced oscillation technique; FVC: forced vital capacity; GI: gastrointestinal; GOLD: Global Initiative for Obstructive Lung Disease; IC: inspiratory capacity; ICS: inhaled corticosteroids; ITT: intention-to-treat; LTOT: long-term oxygen therapy; LVRS: lung volume reduction surgery; MI: myocardial infarction; MRC: Medical Research Council; NAC: N-acetylcysteine; NYHA: New York Heart Association; OCS: oral corticosteroids; OT: on treatment; PaCO $_{2}$ : partial pressure of carbon dioxide; $\mathrm{PaO}_{2}$ : partial pressure of oxygen; PEFR: peak expiratory flow rate; PKU: phenylketonuria; pMDI: pressurised metereddose inhaler; PP: per protocol; SABA: short-acting beta-agonist; SCMC-Lys: carbocysteine lysine salt monohydrate; SD: standard deviation; SE: standard error; SF-36: Short Form-36; SGRQ: St. George's Respiratory Questionnaire; TB: tuberculosis ; VC: vital capacity; WHO: World Health Organization.

\section{Characteristics of excluded studies [ordered by study ID]}




\begin{tabular}{|c|c|}
\hline Study & Reason for exclusion \\
\hline Baglioni 2001 & $\begin{array}{l}\text { Preliminary, small, open RCT of NAC vs placebo in patients on LTOT, published in abstract form on- } \\
\text { ly, with no numerical data on clinical outcomes }\end{array}$ \\
\hline Cattaneo 2001 & Only 20 days long \\
\hline Christensen 1971 & $\begin{array}{l}\text { No response to } 2 \text { letters requesting more data. Old study - unlikely to be successful with further at- } \\
\text { tempts. Did not evaluate primary outcome, although did evaluate days sick }\end{array}$ \\
\hline Edwards 1976 & Did not evaluate primary outcome \\
\hline Habich 1994 & Included both patients with asthma and patients with COPD \\
\hline Kasielski 2001 & Did not evaluate clinical outcomes \\
\hline Lukas 2005 & $\begin{array}{l}\text { Translated from German. Patients with chronic bronchitis given NAC, placebo, Vit C or NAC + Vit C } \\
\text { for } 3 \text { months. Did not evaluate primary outcome. Outcomes were lung function, symptoms, neu- } \\
\text { trophils, and other blood outcomes such as oxidising ability. No numerical data presented on lung } \\
\text { function or symptoms, although study authors reported no differences for either of these }\end{array}$ \\
\hline Maesen 1980 & Did not evaluate primary outcome \\
\hline Michnar 1996 & Did not evaluate primary outcome \\
\hline Moretti 2011 & Acute setting; 10 days of treatment with erdosteine \\
\hline Moretti 2014 & Acute setting; 10 days of treatment with erdosteine \\
\hline Pirabbasi 2016 & Four-arm study including NAC and placebo; focus on nutritional and antioxidant status \\
\hline Rubin 1996 & Did not evaluate primary outcome \\
\hline Saibene 2016 & Trial not an RCT. Used a before and after design with all participants taking carbocysteine \\
\hline Salve 2016 & $\begin{array}{l}\text { Randomised trial of combined effect of NAC and daily physical activity in stable COPD; thus impos- } \\
\text { sible to determine NAC effect }\end{array}$ \\
\hline Sushko 2015 & Study specifically in people with COPD post-Chernobyl, so not a typical, stable COPD population \\
\hline Tatsumi 2007a & Even though randomised, not placebo-controlled \\
\hline Tatsumi 2007b & Even though randomised, not placebo-controlled \\
\hline Velazquez 2001 & Only 4 weeks long \\
\hline Wilhelmi 2010 & $\begin{array}{l}\text { Has been translated from German. Patients with COPD given cineole or placebo for } 6 \text { months. Eval- } \\
\text { uated primary outcome of exacerbations; although P values given for a significant reduction in ex- } \\
\text { acerbations with cineole compared with placebo, no data supplied for event rates. Appears to be a } \\
\text { short report summarising original trial }\end{array}$ \\
\hline
\end{tabular}

COPD: chronic obstructive pulmonary disease; LTOT: long-term oxygen therapy; NAC: N-acetylcysteine; RCT: randomised controlled trial; vs: versus.

Characteristics of studies awaiting assessment [ordered by study ID] 


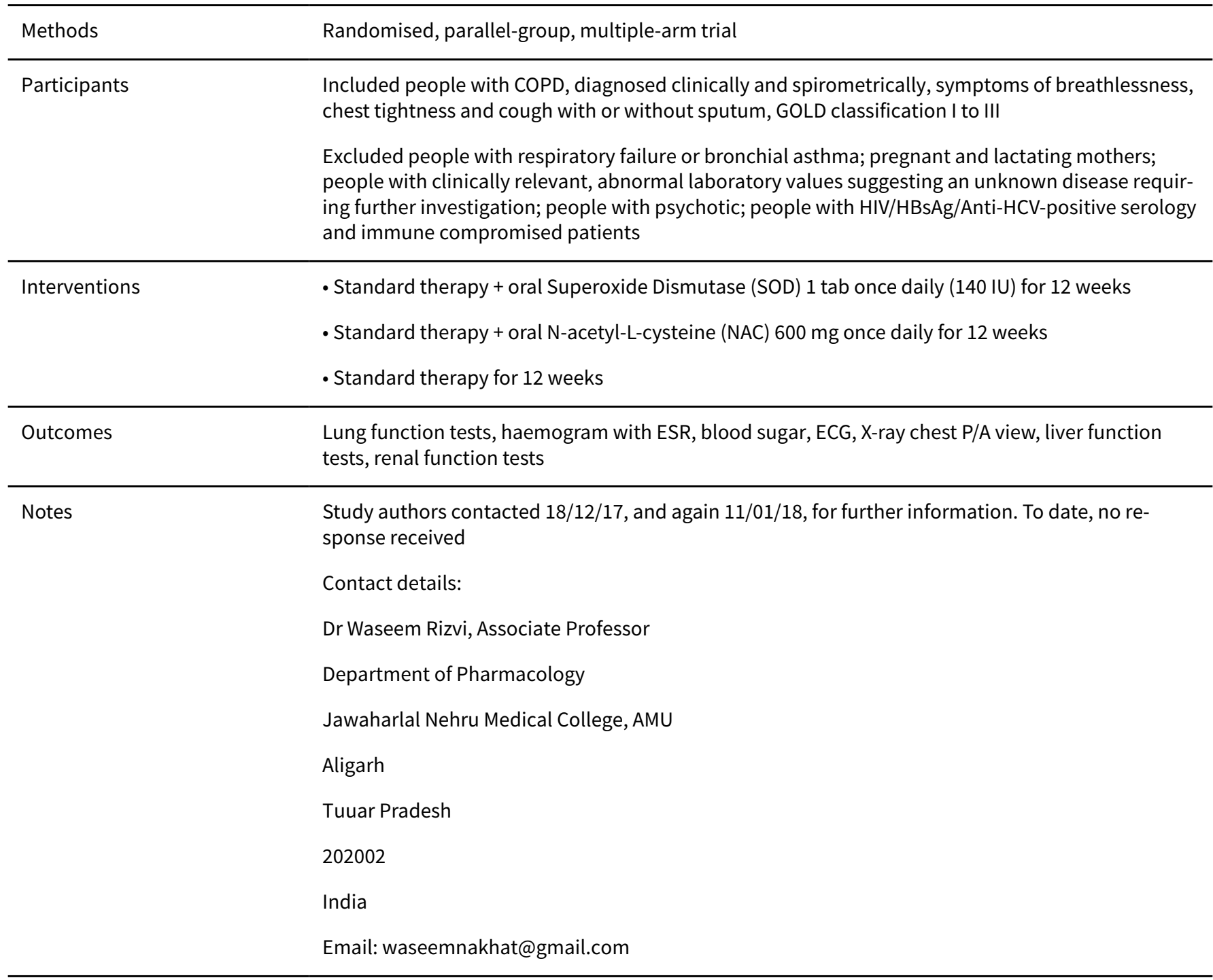

COPD: chronic obstructive pulmonary disease; ECG: electrocardiogram; ESR: erythrocyte sedimentation rate; GOLD: Global Initiative for Obstructive Lung Disease; HBsAg: surface antigen of hepatitis B virus; HCV: hepatitis C virus; HIV: human immunodeficiency virus; NAC: Nacetylcysteine; P/A: posteroanterior.

Characteristics of ongoing studies [ordered by study ID]

\section{ChicTR-IIR-17012604}

Trial name or title
Long-term regular treatment of early COPD with randomised, double-blind, placebo-controlled multi-centre clinical study with acetylcysteine effervescent tablets

Methods Parallel randomised double-blind placebo-controlled trial

Participants

Aged 40 to 80 years, male or female, community or outpatient; with respiratory symptoms (chronic cough, sputum, shortness of breath) and/or chronic obstructive pulmonary exposure risk factors (smoking, occupational exposure, indoor and outdoor air pollution, family history of COPD, recurrent respiratory tract infection, low birth weight, and genetic factors, etc.); GOLD stage I to II COPD: $\mathrm{FEV}_{1} / \mathrm{FVC}<70 \%$; and $\mathrm{FEV}_{1} \geq 50 \%$ predicted after 20 minutes with $400 \mu \mathrm{g}$ of salbutamol inhalation; patients in a stable period, that is, nearly 4 weeks without COPD acute exacerbations; patient is 
ChiCTR-IIR-17012604 (Continued)

able to communicate in words, agrees, and has the ability to complete the test-related auxiliary examination. Signs informed consent

\begin{tabular}{ll}
\hline Interventions & Acetylcysteine effervescent tablets vs placebo \\
\hline Outcomes & $\begin{array}{l}\text { Lung function, number of acute exacerbations of COPD, quality of life (CAT), symptom score, COPD } \\
\text { acute exacerbation severity, adverse events, attrition }\end{array}$ \\
\hline Starting date & $2017-09-06$ \\
\hline Contact information & Yumin Zhou: zhouyumin410@126.com \\
& The First Affiliated Hospital of Guangzhou Medical University \\
& 151 Yanjiang Road \\
Guangzhou & Guangdong \\
China
\end{tabular}

Notes

\section{ChiCTR1800016712}

Trial name or title

Early intervention with carbocysteine and low-dose theophylline in Chinese patients with chronic obstructive pulmonary disease

\begin{tabular}{ll}
\hline Methods & Multi-centre clinical study screening for effective drugs for early-stage COPD. Parallel RCT \\
\hline Participants & Community or clinic COPD patients, between 40 and 80 years of age, male or female; FEV $/$ FVC $<$ \\
$70 \%$ after inhaled bronchodilator; $\mathrm{FEV}_{1} 50 \%$ predicted (Gold stage I to II); no acute exacerbation of \\
COPD in the last 4 weeks; ability to communicate in languages or words; ability to voluntarily par- \\
ticipate in the study and sign informed consent
\end{tabular}

\begin{tabular}{ll}
\hline Interventions & $\begin{array}{l}\text { Carbocysteine tablets } 500 \mathrm{mg}, 3 \text { times daily; theophylline sustained-release tablets } 100 \text { mg, } 2 \text { times } \\
\text { daily; carbocysteine-placebo group: carbocysteine-placebo tablets } 500 \text { mg } 3 \text { times daily; theo- } \\
\text { phylline-placebo group: theophylline sustained-release placebo tablets } 100 \text { mg, } 2 \text { times daily }\end{array}$ \\
\hline Outcomes & $\begin{array}{l}\text { Lung function; number of COPD exacerbations; symptom score; time to first acute exacerbation of } \\
\text { COPD; severity, interval, and duration of acute exacerbations of COPD; dropout rate; administra- } \\
\text { tion of rescue medication; cost-effectiveness analysis }\end{array}$ \\
\hline Starting date & 2018-06-25 \\
\hline Contact information & Wang Qiuyue: qywngcmu@163.com \\
& The First Hospital of China Medical University \\
& 155 Nanjing Street North \\
& Heping District \\
& Shenyang, Liaoning \\
China &
\end{tabular}


ChiCTR1800016712 (Continued)

Notes

CAT: COPD Assessment Test; COPD: chronic obstructive pulmonary disease; $\mathrm{FEV}_{1}$ : forced expiratory volume in one second; FVC: forced vital capacity; GOLD: Global Initiative for Obstructive Lung Disease; RCT: randomised controlled trial.

\section{DATA AND ANALYSES}

\section{Comparison 1. Mucolytic versus placebo}

\begin{tabular}{|c|c|c|c|c|}
\hline Outcome or subgroup title & No. of studies & $\begin{array}{l}\text { No. of partici- } \\
\text { pants }\end{array}$ & Statistical method & Effect size \\
\hline $\begin{array}{l}1 \text { Participants with no exacer- } \\
\text { bations in study period }\end{array}$ & 28 & 6723 & $\begin{array}{l}\text { Peto Odds Ratio (Peto, Fixed, 95\% } \\
\mathrm{Cl} \text { ) }\end{array}$ & $1.73[1.56,1.91]$ \\
\hline 1.1 Double-blind & 26 & 6460 & $\begin{array}{l}\text { Peto Odds Ratio (Peto, Fixed, 95\% } \\
\mathrm{Cl} \text { ) }\end{array}$ & $1.69[1.53,1.88]$ \\
\hline 1.2 Single-blind/open & 2 & 263 & $\begin{array}{l}\text { Peto Odds Ratio (Peto, Fixed, 95\% } \\
\mathrm{Cl} \text { ) }\end{array}$ & $2.91[1.76,4.83]$ \\
\hline $\begin{array}{l}2 \text { Participants with no ex- } \\
\text { acerbation by decade, dou- } \\
\text { ble-blind trials only }\end{array}$ & 26 & 6460 & $\begin{array}{l}\text { Peto Odds Ratio (Peto, Fixed, 95\% } \\
\mathrm{Cl} \text { ) }\end{array}$ & $1.69[1.53,1.88]$ \\
\hline 2.1 Before 1990 & 12 & 2304 & $\begin{array}{l}\text { Peto Odds Ratio (Peto, Fixed, 95\% } \\
\mathrm{Cl} \text { ) }\end{array}$ & $2.34[1.97,2.79]$ \\
\hline 2.21990 to 1999 & 5 & 1105 & $\begin{array}{l}\text { Peto Odds Ratio (Peto, Fixed, 95\% } \\
\mathrm{Cl} \text { ) }\end{array}$ & $1.91[1.50,2.44]$ \\
\hline 2.32000 to 2009 & 5 & 1477 & $\begin{array}{l}\text { Peto Odds Ratio (Peto, Fixed, 95\% } \\
\mathrm{Cl} \text { ) }\end{array}$ & $1.24[1.01,1.54]$ \\
\hline 2.42010 onwards & 4 & 1574 & $\begin{array}{l}\text { Peto Odds Ratio (Peto, Fixed, 95\% } \\
\mathrm{Cl} \text { ) }\end{array}$ & $1.28[1.03,1.59]$ \\
\hline $\begin{array}{l}3 \text { Participants with no exacer- } \\
\text { bations in the study period - } \\
\text { winter treatment only }\end{array}$ & 21 & 4007 & $\begin{array}{l}\text { Peto Odds Ratio (Peto, Fixed, 95\% } \\
\mathrm{Cl} \text { ) }\end{array}$ & $2.20[1.93,2.51]$ \\
\hline 3.1 Double-blind & 20 & 3844 & $\begin{array}{l}\text { Peto Odds Ratio (Peto, Fixed, 95\% } \\
\mathrm{Cl} \text { ) }\end{array}$ & $2.18[1.91,2.49]$ \\
\hline 3.2 Single-blind/open & 1 & 163 & $\begin{array}{l}\text { Peto Odds Ratio (Peto, Fixed, 95\% } \\
\mathrm{Cl} \text { ) }\end{array}$ & $2.85[1.49,5.46]$ \\
\hline $\begin{array}{l}4 \text { Participants with no exac- } \\
\text { erbations in study period - by } \\
\text { dose or type of mucolytic }\end{array}$ & 28 & 6723 & $\begin{array}{l}\text { Peto Odds Ratio (Peto, Fixed, 95\% } \\
\mathrm{Cl} \text { ) }\end{array}$ & $1.73[1.56,1.91]$ \\
\hline $4.1 \mathrm{NAC} 400 \mathrm{mg}$ & 3 & 717 & $\begin{array}{l}\text { Peto Odds Ratio (Peto, Fixed, 95\% } \\
\mathrm{Cl} \text { ) }\end{array}$ & $2.98[2.21,4.03]$ \\
\hline
\end{tabular}




\begin{tabular}{|c|c|c|c|c|}
\hline Outcome or subgroup title & No. of studies & $\begin{array}{l}\text { No. of partici- } \\
\text { pants }\end{array}$ & Statistical method & Effect size \\
\hline 4.2 NAC $600 \mathrm{mg}$ & 9 & 1425 & $\begin{array}{l}\text { Peto Odds Ratio (Peto, Fixed, 95\% } \\
\mathrm{Cl} \text { ) }\end{array}$ & $1.76[1.40,2.21]$ \\
\hline $4.3 \mathrm{NAC} 1200 \mathrm{mg}$ & 3 & 1213 & $\begin{array}{l}\text { Peto Odds Ratio (Peto, Fixed, 95\% } \\
\mathrm{Cl} \text { ) }\end{array}$ & $1.22[0.95,1.57]$ \\
\hline $4.5 \mathrm{NAC} 3200 \mathrm{mg}$ & 1 & 45 & $\begin{array}{l}\text { Peto Odds Ratio (Peto, Fixed, 95\% } \\
\mathrm{Cl} \text { ) }\end{array}$ & $0.52[0.14,2.01]$ \\
\hline 4.6 Carbocysteine & 4 & 1251 & $\begin{array}{l}\text { Peto Odds Ratio (Peto, Fixed, 95\% } \\
\mathrm{Cl} \text { ) }\end{array}$ & $1.41[1.13,1.77]$ \\
\hline 4.7 Other mucolytic & 8 & 2072 & $\begin{array}{l}\text { Peto Odds Ratio (Peto, Fixed, 95\% } \\
\mathrm{Cl} \text { ) }\end{array}$ & $1.97[1.64,2.36]$ \\
\hline $\begin{array}{l}5 \text { Participants with no exac- } \\
\text { erbations in study period - by } \\
\mathrm{FEV}_{1}\end{array}$ & 28 & 6723 & $\begin{array}{l}\text { Peto Odds Ratio (Peto, Fixed, 95\% } \\
\mathrm{Cl} \text { ) }\end{array}$ & $1.73[1.56,1.91]$ \\
\hline 5.1 Mean $\mathrm{FEV}_{1}>50 \%$ predicted & 24 & 5352 & $\begin{array}{l}\text { Peto Odds Ratio (Peto, Fixed, 95\% } \\
\mathrm{Cl} \text { ) }\end{array}$ & $1.81[1.62,2.03]$ \\
\hline 5.2 Mean FEV $_{1} \leq 50 \%$ predicted & 4 & 1371 & $\begin{array}{l}\text { Peto Odds Ratio (Peto, Fixed, 95\% } \\
\mathrm{Cl} \text { ) }\end{array}$ & $1.38[1.08,1.75]$ \\
\hline $\begin{array}{l}6 \text { Participants with no exac- } \\
\text { erbations in study period - by } \\
\text { study duration }\end{array}$ & 28 & 6723 & $\begin{array}{l}\text { Peto Odds Ratio (Peto, Fixed, 95\% } \\
\mathrm{Cl} \text { ) }\end{array}$ & $1.73[1.56,1.91]$ \\
\hline 6.1 Duration $\leq 3$ months & 5 & 903 & $\begin{array}{l}\text { Peto Odds Ratio (Peto, Fixed, 95\% } \\
\mathrm{Cl} \text { ) }\end{array}$ & $2.14[1.62,2.82]$ \\
\hline $\begin{array}{l}6.2 \text { Duration }>3 \text { months and }< \\
12 \text { months }\end{array}$ & 18 & 3278 & $\begin{array}{l}\text { Peto Odds Ratio (Peto, Fixed, 95\% } \\
\mathrm{Cl} \text { ) }\end{array}$ & $2.20[1.91,2.54]$ \\
\hline 6.3 Duration $\geq 12$ months & 5 & 2542 & $\begin{array}{l}\text { Peto Odds Ratio (Peto, Fixed, 95\% } \\
\mathrm{Cl} \text { ) }\end{array}$ & $1.16[0.98,1.37]$ \\
\hline $\begin{array}{l}7 \text { Participants with no exac- } \\
\text { erbations in study period - by } \\
\text { country }\end{array}$ & 28 & 6723 & $\begin{array}{l}\text { Peto Odds Ratio (Peto, Fixed, 95\% } \\
\mathrm{Cl} \text { ) }\end{array}$ & $1.73[1.56,1.91]$ \\
\hline 7.1 Italian & 11 & 2407 & $\begin{array}{l}\text { Peto Odds Ratio (Peto, Fixed, 95\% } \\
\mathrm{Cl} \text { ) }\end{array}$ & $2.44[2.06,2.88]$ \\
\hline 7.2 Rest of world & 17 & 4316 & $\begin{array}{l}\text { Peto Odds Ratio (Peto, Fixed, 95\% } \\
\mathrm{Cl} \text { ) }\end{array}$ & $1.41[1.25,1.61]$ \\
\hline $\begin{array}{l}8 \text { Participants with no exac- } \\
\text { erbations in study period - by } \\
\text { history of exacerbation }\end{array}$ & 28 & 6723 & $\begin{array}{l}\text { Peto Odds Ratio (Peto, Fixed, 95\% } \\
\mathrm{Cl} \text { ) }\end{array}$ & $1.73[1.56,1.91]$ \\
\hline $\begin{array}{l}\text { 8.1 Exacerbation history re- } \\
\text { quirement for inclusion }\end{array}$ & 16 & 4192 & $\begin{array}{l}\text { Peto Odds Ratio (Peto, Fixed, 95\% } \\
\mathrm{Cl} \text { ) }\end{array}$ & $1.50[1.32,1.70]$ \\
\hline
\end{tabular}




\begin{tabular}{|c|c|c|c|c|}
\hline Outcome or subgroup title & No. of studies & $\begin{array}{l}\text { No. of partici- } \\
\text { pants }\end{array}$ & Statistical method & Effect size \\
\hline $\begin{array}{l}8.2 \text { Exacerbation history not a } \\
\text { requirement for inclusion }\end{array}$ & 12 & 2531 & $\begin{array}{l}\text { Peto Odds Ratio (Peto, Fixed, 95\% } \\
\mathrm{Cl} \text { ) }\end{array}$ & $2.18[1.85,2.57]$ \\
\hline $\begin{array}{l}9 \text { Participants with no exacer- } \\
\text { bations in study period - by ICS } \\
\text { use }\end{array}$ & 28 & 6723 & $\begin{array}{l}\text { Peto Odds Ratio (Peto, Fixed, 95\% } \\
\mathrm{Cl} \text { ) }\end{array}$ & $1.73[1.56,1.91]$ \\
\hline 9.1 ICS allowed & 15 & 4401 & $\begin{array}{l}\text { Peto Odds Ratio (Peto, Fixed, 95\% } \\
\mathrm{Cl} \text { ) }\end{array}$ & $1.65[1.46,1.87]$ \\
\hline 9.2 ICS not allowed & 6 & 1431 & $\begin{array}{l}\text { Peto Odds Ratio (Peto, Fixed, 95\% } \\
\mathrm{Cl} \text { ) }\end{array}$ & $1.85[1.49,2.31]$ \\
\hline 9.3 ICS unclear & 7 & 891 & $\begin{array}{l}\text { Peto Odds Ratio (Peto, Fixed, 95\% } \\
\mathrm{Cl} \text { ) }\end{array}$ & $1.95[1.48,2.58]$ \\
\hline $\begin{array}{l}10 \text { Number of exacerbations } \\
\text { per participant per month }\end{array}$ & & & Other data & No numeric data \\
\hline $\begin{array}{l}11 \text { Days of disability per partic- } \\
\text { ipant per month }\end{array}$ & 9 & 2259 & Mean Difference (IV, Fixed, 95\% CI) & $-0.43[-0.56,-0.30]$ \\
\hline $\begin{array}{l}12 \text { Days on antibiotics per par- } \\
\text { ticipant per month }\end{array}$ & 3 & 714 & Mean Difference (IV, Fixed, 95\% CI) & $-0.53[-0.76,-0.31]$ \\
\hline $13 \mathrm{FEV}_{1}$ at end of study & 14 & 3473 & Mean Difference (IV, Fixed, 95\% CI) & $0.04[0.01,0.07]$ \\
\hline 13.1 Double-blind & 13 & 3310 & Mean Difference (IV, Fixed, 95\% CI) & $0.04[0.01,0.07]$ \\
\hline 13.2 Single-blind & 1 & 163 & Mean Difference (IV, Fixed, 95\% CI) & $0.08[-0.10,0.26]$ \\
\hline 14 Percent predicted FEV 1 & 4 & 414 & Mean Difference (IV, Fixed, 95\% CI) & $4.79[1.97,7.62]$ \\
\hline 14.1 Double-blind & 2 & 230 & Mean Difference (IV, Fixed, 95\% CI) & $-0.13[-4.72,4.47]$ \\
\hline 14.2 Single-blind & 1 & 100 & Mean Difference (IV, Fixed, 95\% CI) & $0.70[-4.02,5.42]$ \\
\hline 14.3 No blinding & 1 & 84 & Mean Difference (IV, Fixed, 95\% CI) & $17.31[11.83,22.79]$ \\
\hline 15 PEFR at end of study & 1 & & Mean Difference (IV, Fixed, 95\% CI) & Totals not selected \\
\hline 15.1 Double-blind & 1 & & Mean Difference (IV, Fixed, 95\% CI) & $0.0[0.0,0.0]$ \\
\hline $16 \mathrm{FVC}$ at end of study & 12 & 3127 & Mean Difference (IV, Fixed, 95\% CI) & $0.05[-0.00,0.10]$ \\
\hline 17 Adverse effects & 24 & 7264 & Odds Ratio (M-H, Fixed, 95\% Cl) & $0.84[0.74,0.94]$ \\
\hline $\begin{array}{l}18 \text { Hospitalisation during } \\
\text { study period }\end{array}$ & 5 & 1833 & $\begin{array}{l}\text { Peto Odds Ratio (Peto, Fixed, 95\% } \\
\mathrm{Cl} \text { ) }\end{array}$ & $0.68[0.52,0.89]$ \\
\hline 19 Death during study period & 11 & 3527 & $\begin{array}{l}\text { Peto Odds Ratio (Peto, Fixed, 95\% } \\
\mathrm{Cl} \text { ) }\end{array}$ & $0.98[0.51,1.87]$ \\
\hline
\end{tabular}




\begin{tabular}{lllll}
\hline Outcome or subgroup title & No. of studies & $\begin{array}{l}\text { No. of partici- } \\
\text { pants }\end{array}$ & Statistical method & Effect size \\
\hline $\begin{array}{l}20 \text { Health-related quality of life } \\
\text { (total score St. George's Respi- } \\
\text { ratory Questionnaire) }\end{array}$ & 7 & 2721 & Mean Difference (IV, Fixed, 95\% CI) & -1.37 [-2.85, 0.11] \\
\hline $\begin{array}{l}21 \text { Health-related quality of life } \\
\text { (total score COPD Assessment }\end{array}$ & 1 & & Mean Difference (IV, Fixed, 95\% CI) & Subtotals only \\
Test) & & & \\
\hline
\end{tabular}

Analysis 1.1. Comparison 1 Mucolytic versus placebo, Outcome 1 Participants with no exacerbations in study period.

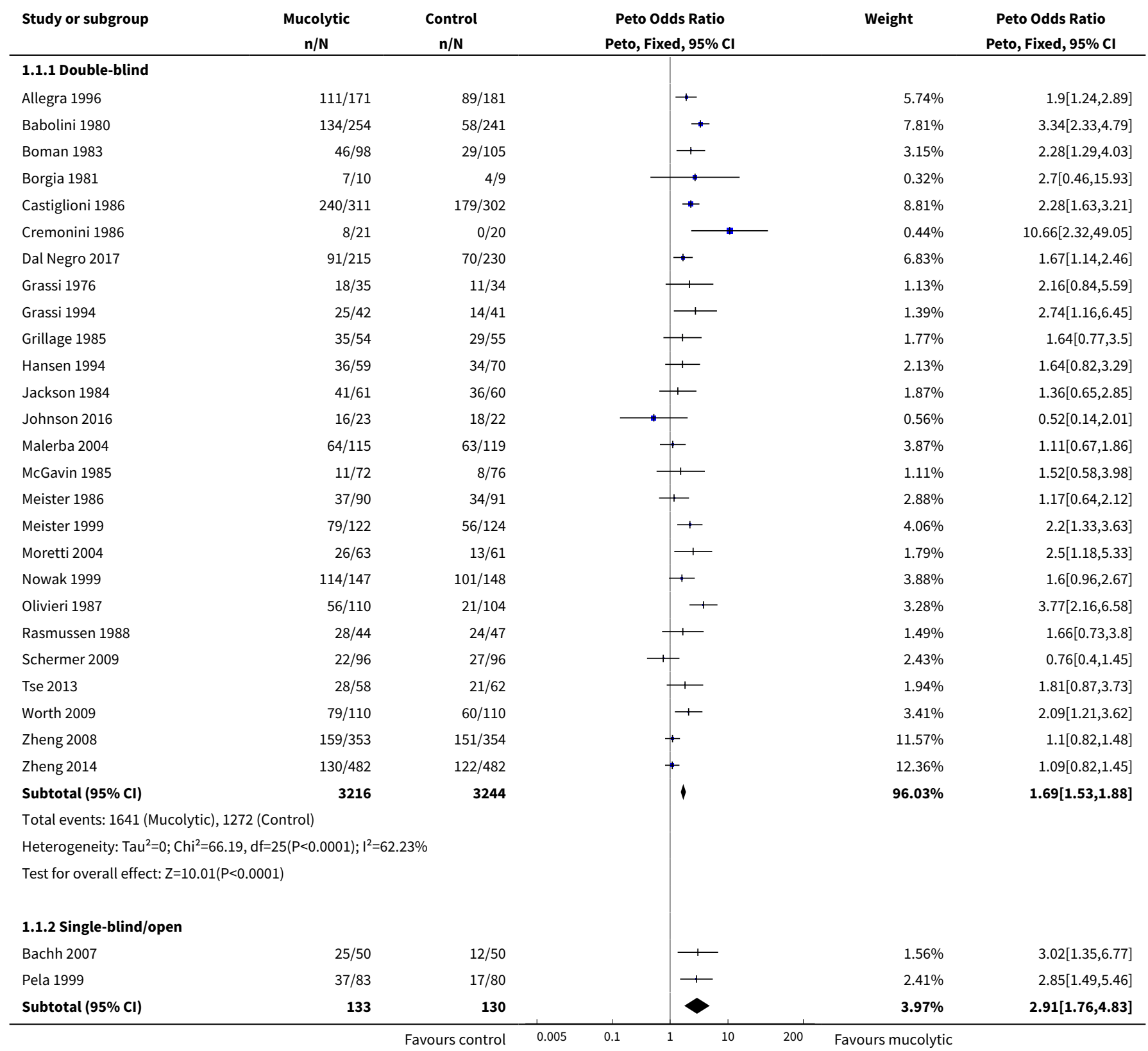




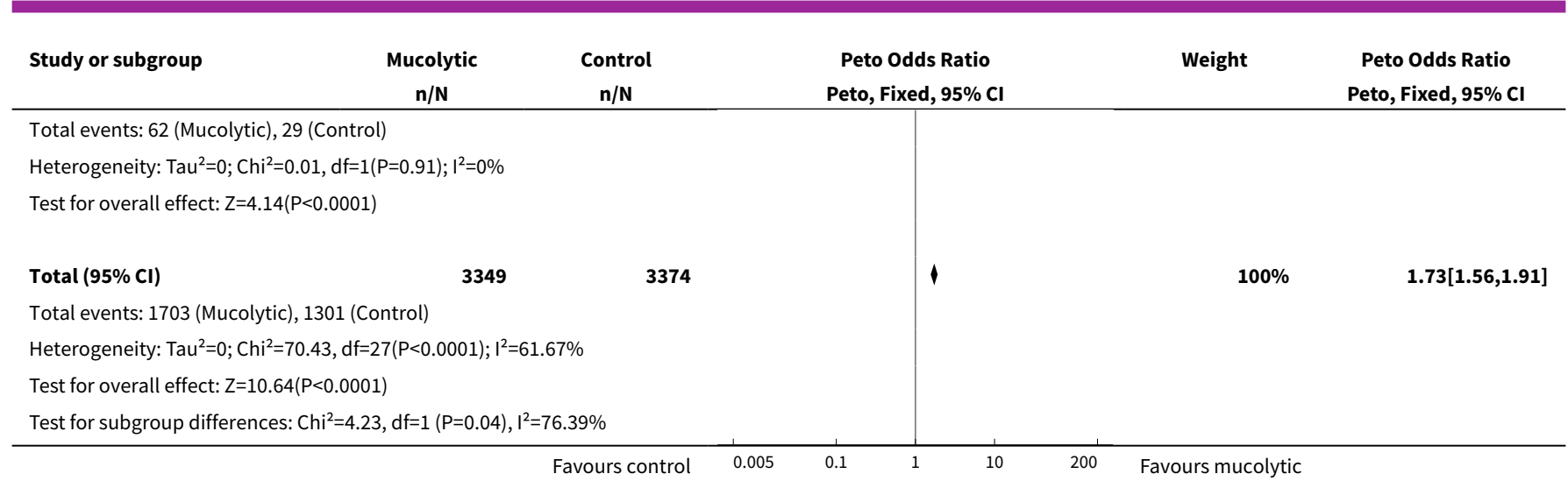

Analysis 1.2. Comparison 1 Mucolytic versus placebo, Outcome 2 Participants with no exacerbation by decade, double-blind trials only.

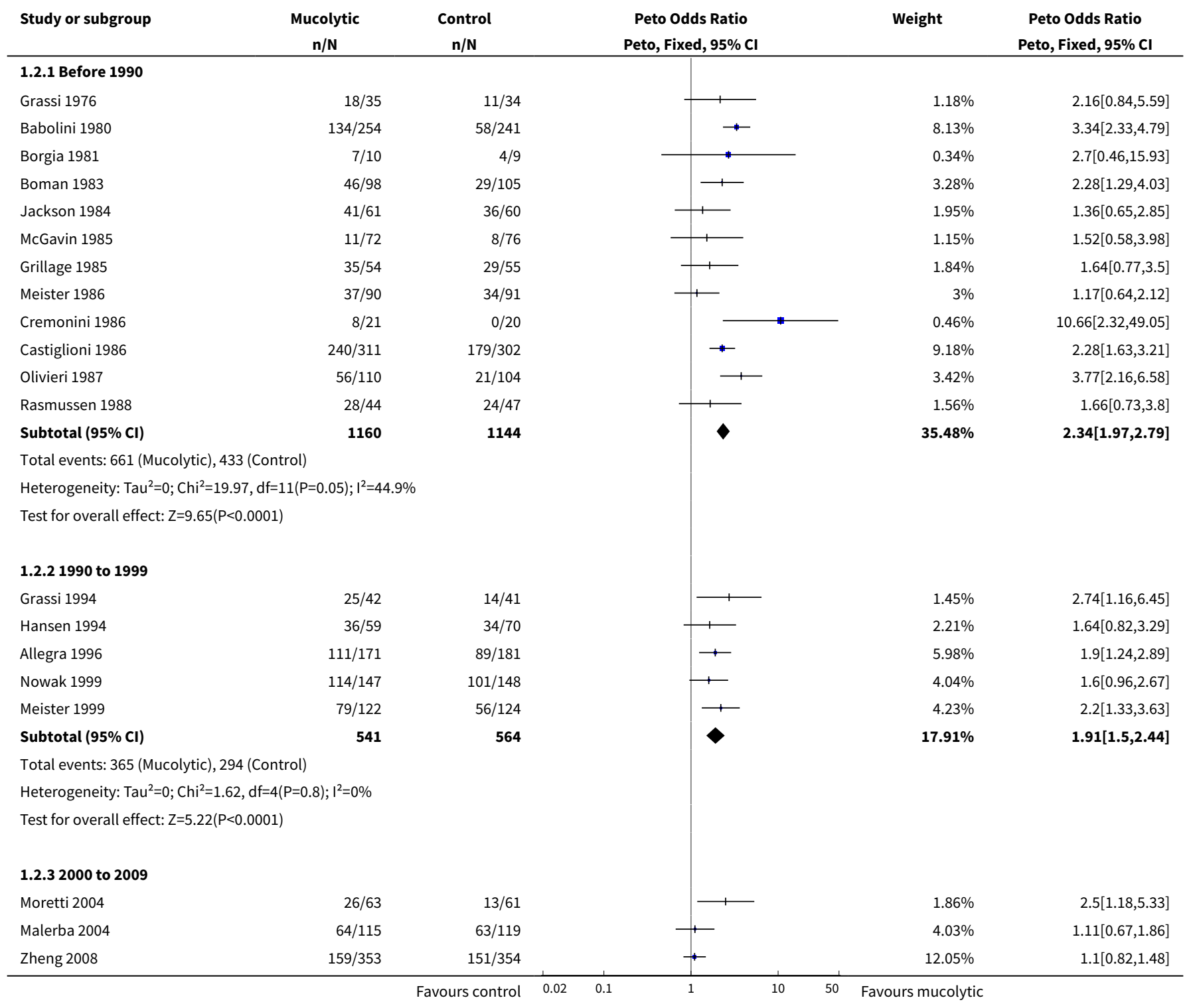




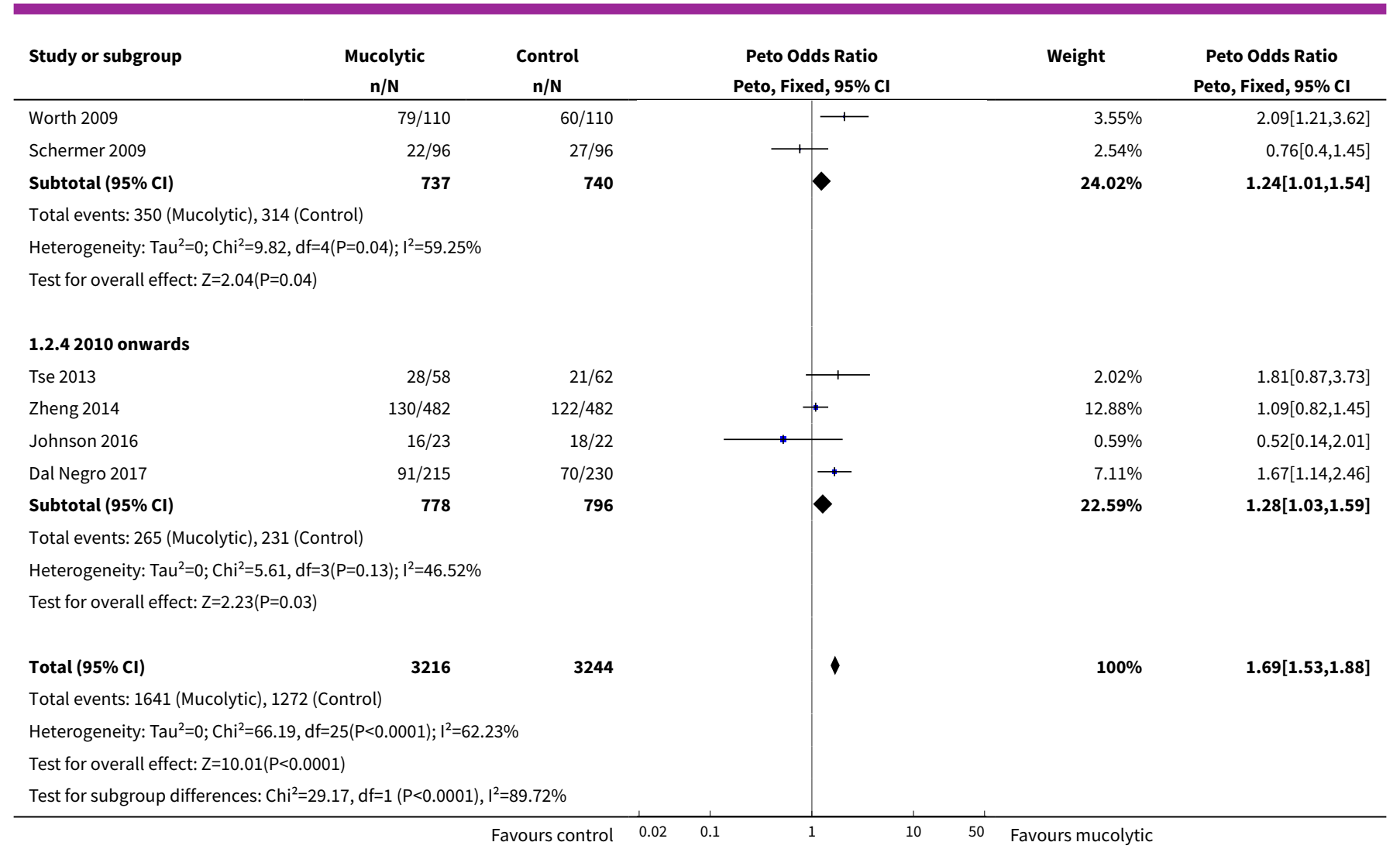

\section{Analysis 1.3. Comparison 1 Mucolytic versus placebo, Outcome 3 Participants with no exacerbations in the study period - winter treatment only.}

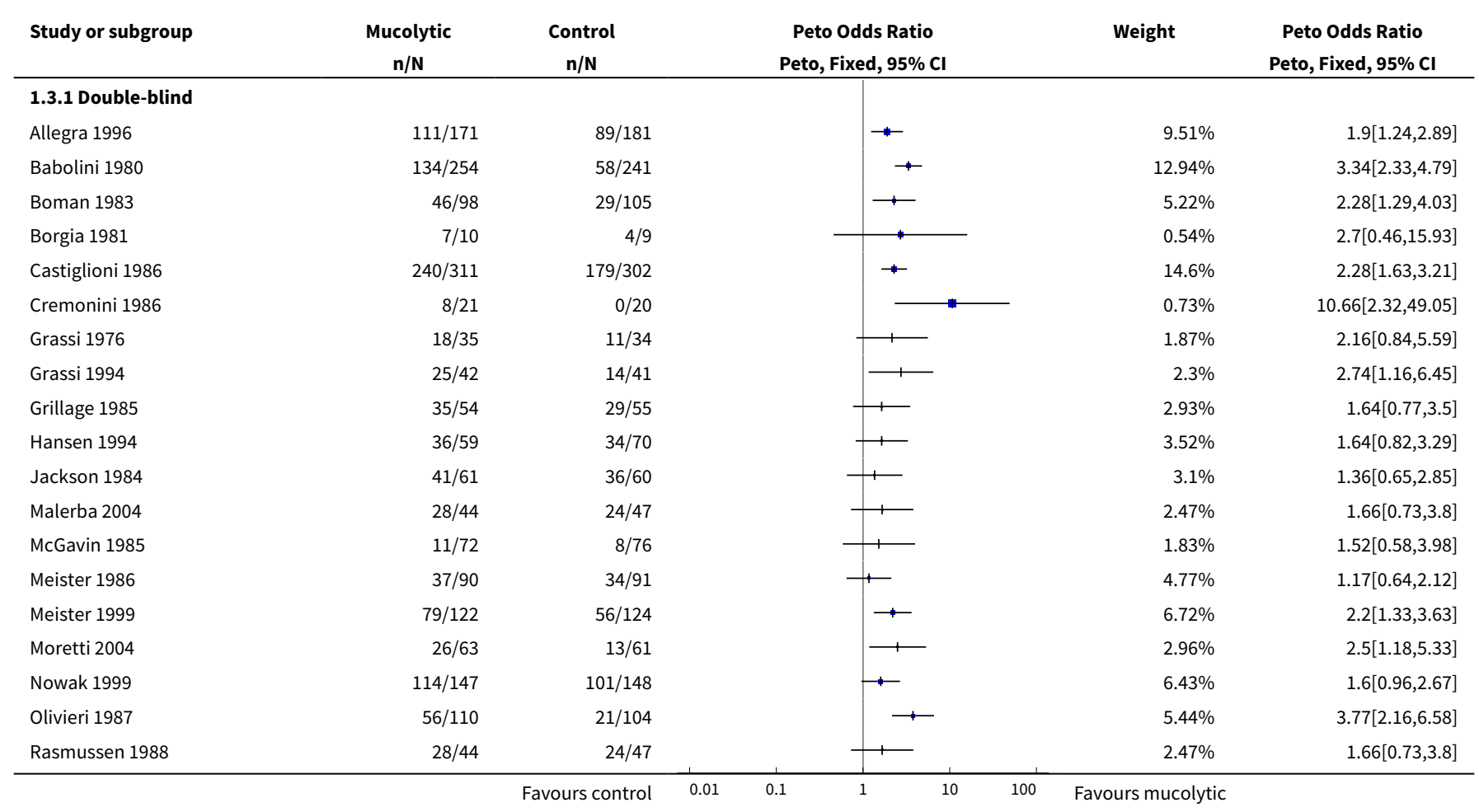




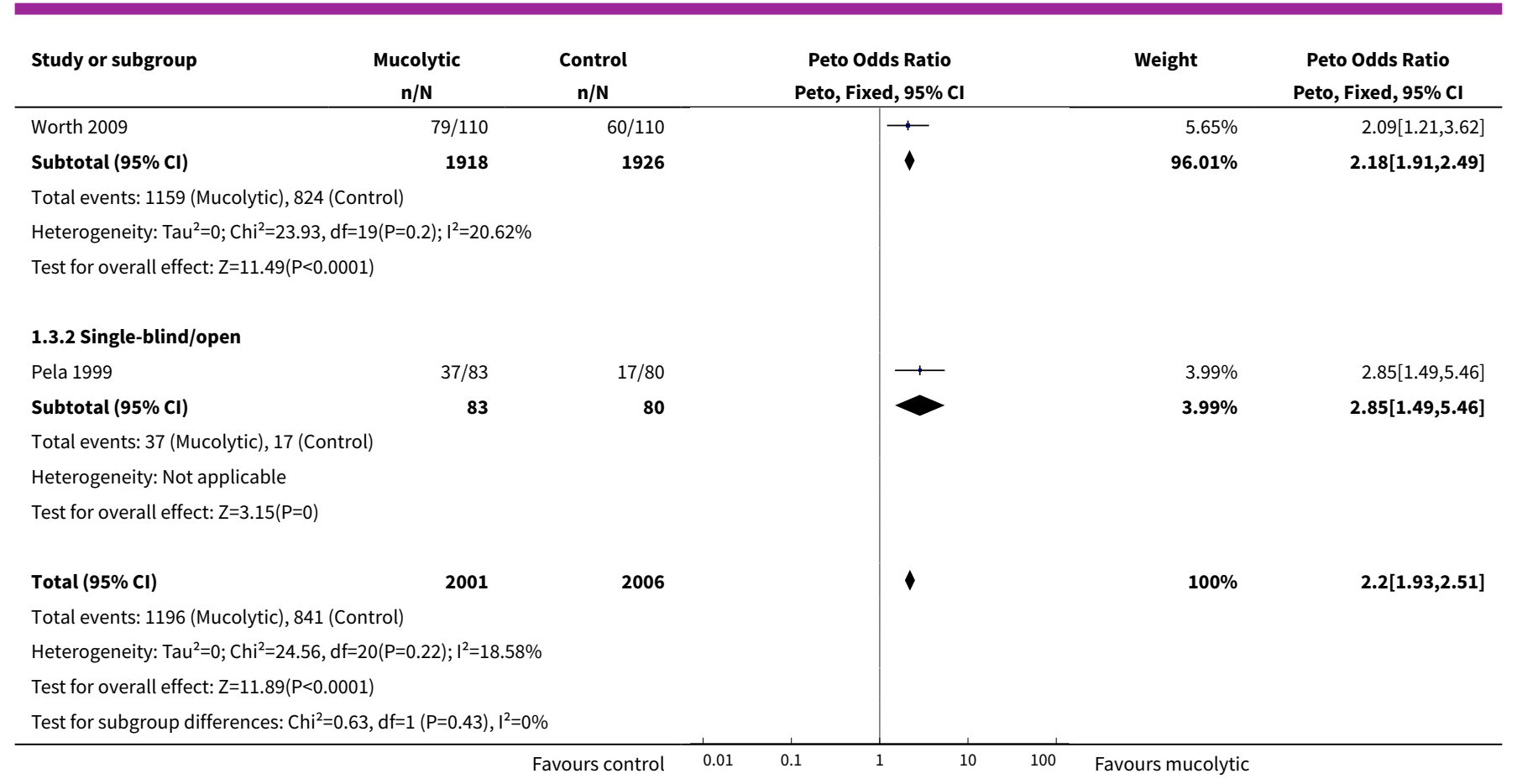

\section{Analysis 1.4. Comparison 1 Mucolytic versus placebo, Outcome 4 Participants with no exacerbations in study period - by dose or type of mucolytic.}

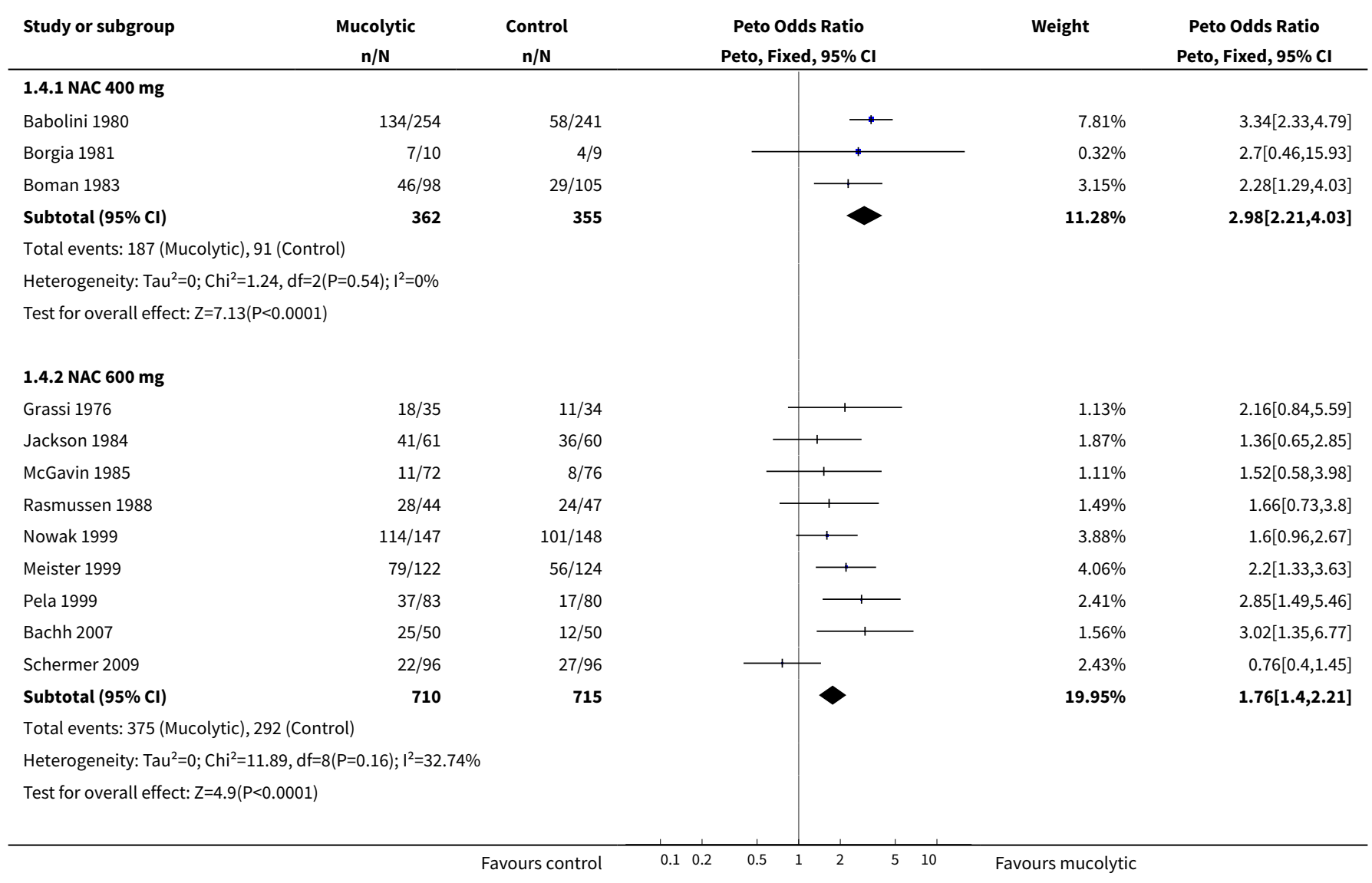




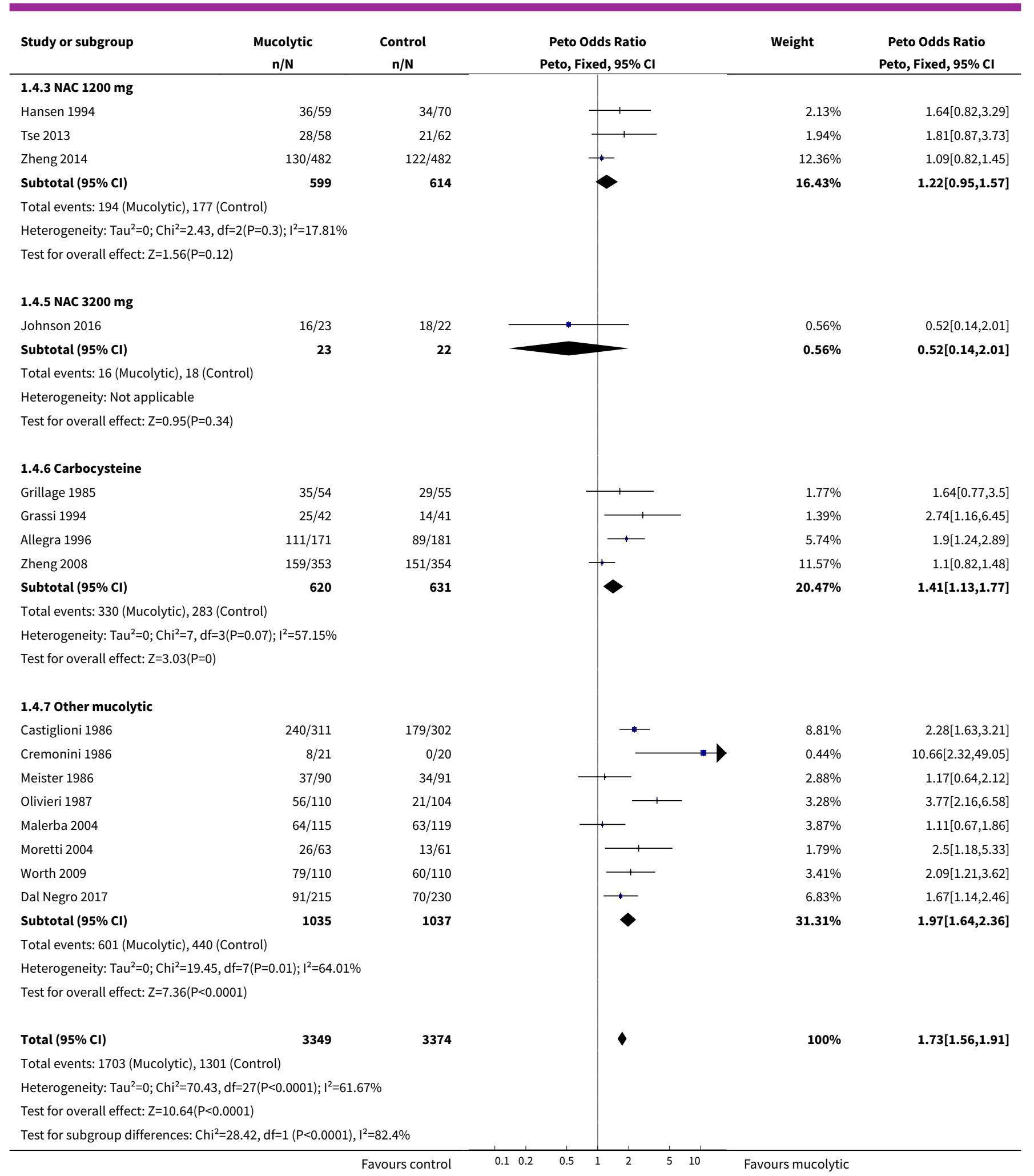


Analysis 1.5. Comparison 1 Mucolytic versus placebo, Outcome 5 Participants with no exacerbations in study period - by FEV $_{1}$.

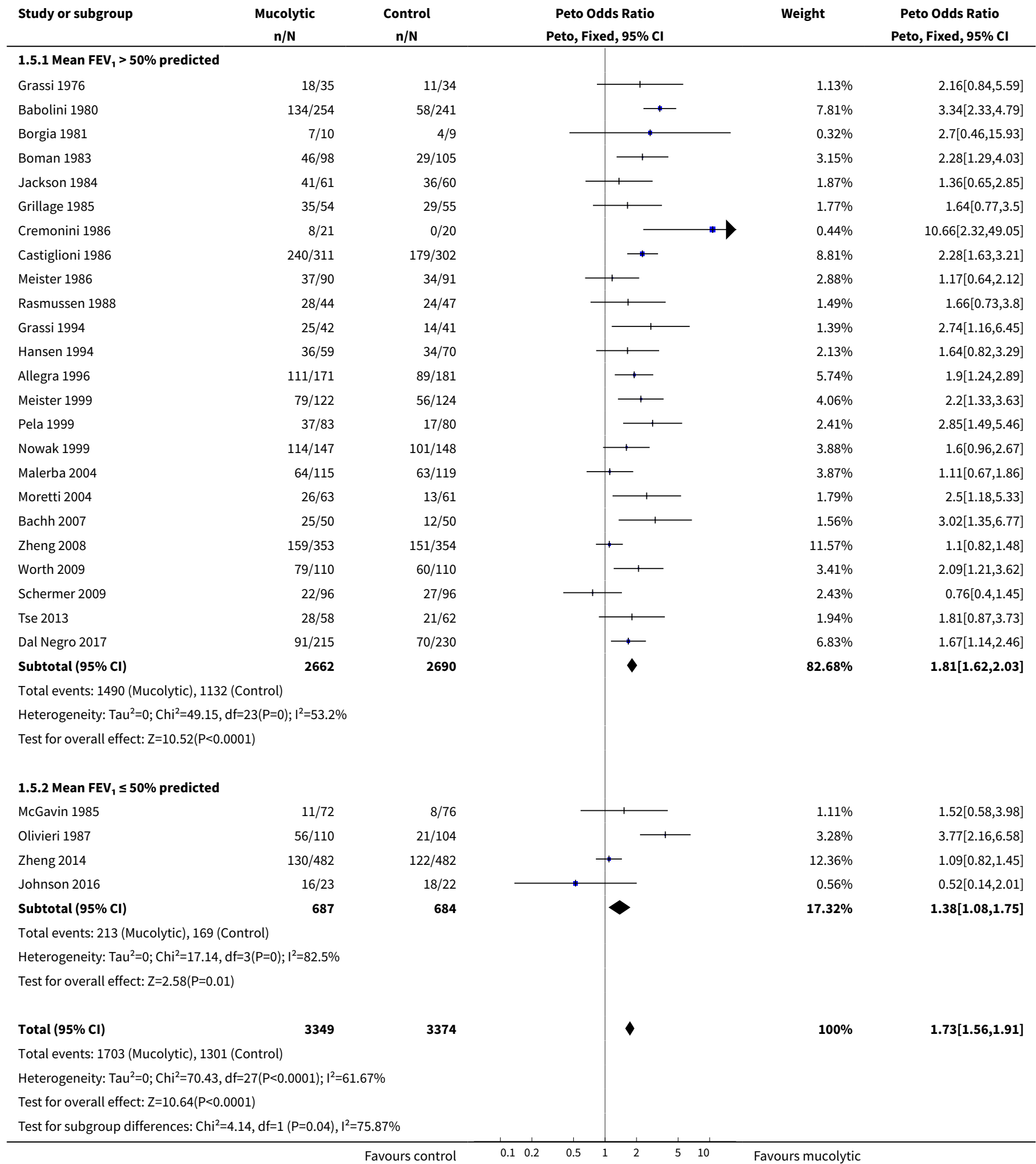


Analysis 1.6. Comparison 1 Mucolytic versus placebo, Outcome 6 Participants with no exacerbations in study period - by study duration.

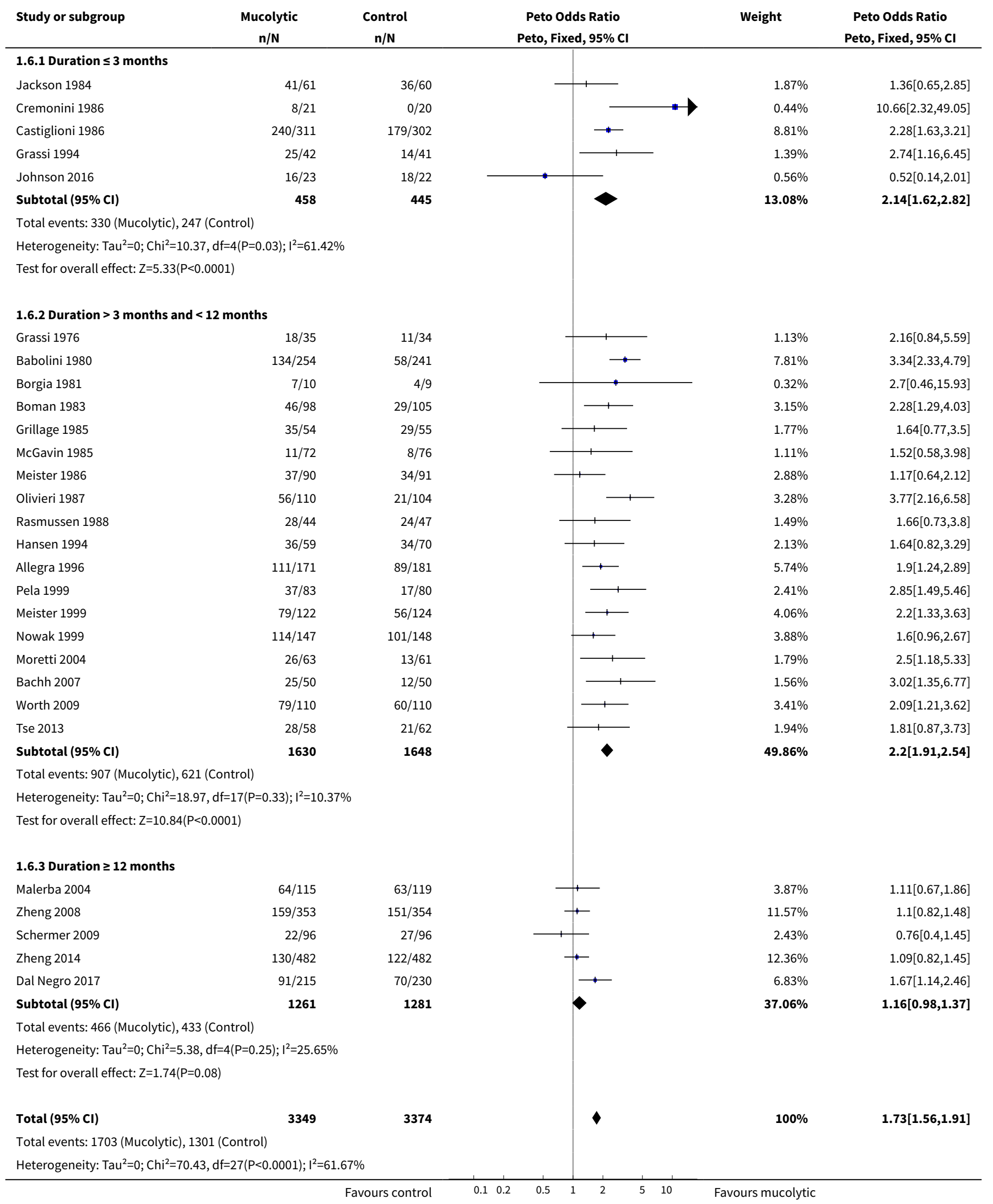




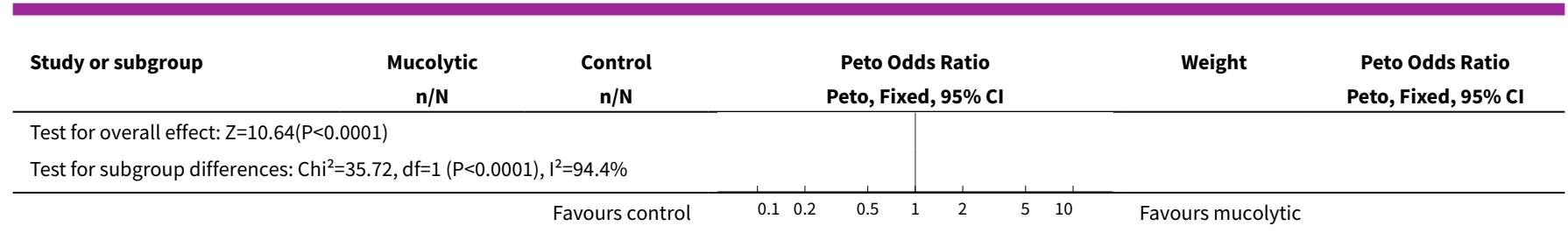

Analysis 1.7. Comparison 1 Mucolytic versus placebo, Outcome 7 Participants with no exacerbations in study period - by country.

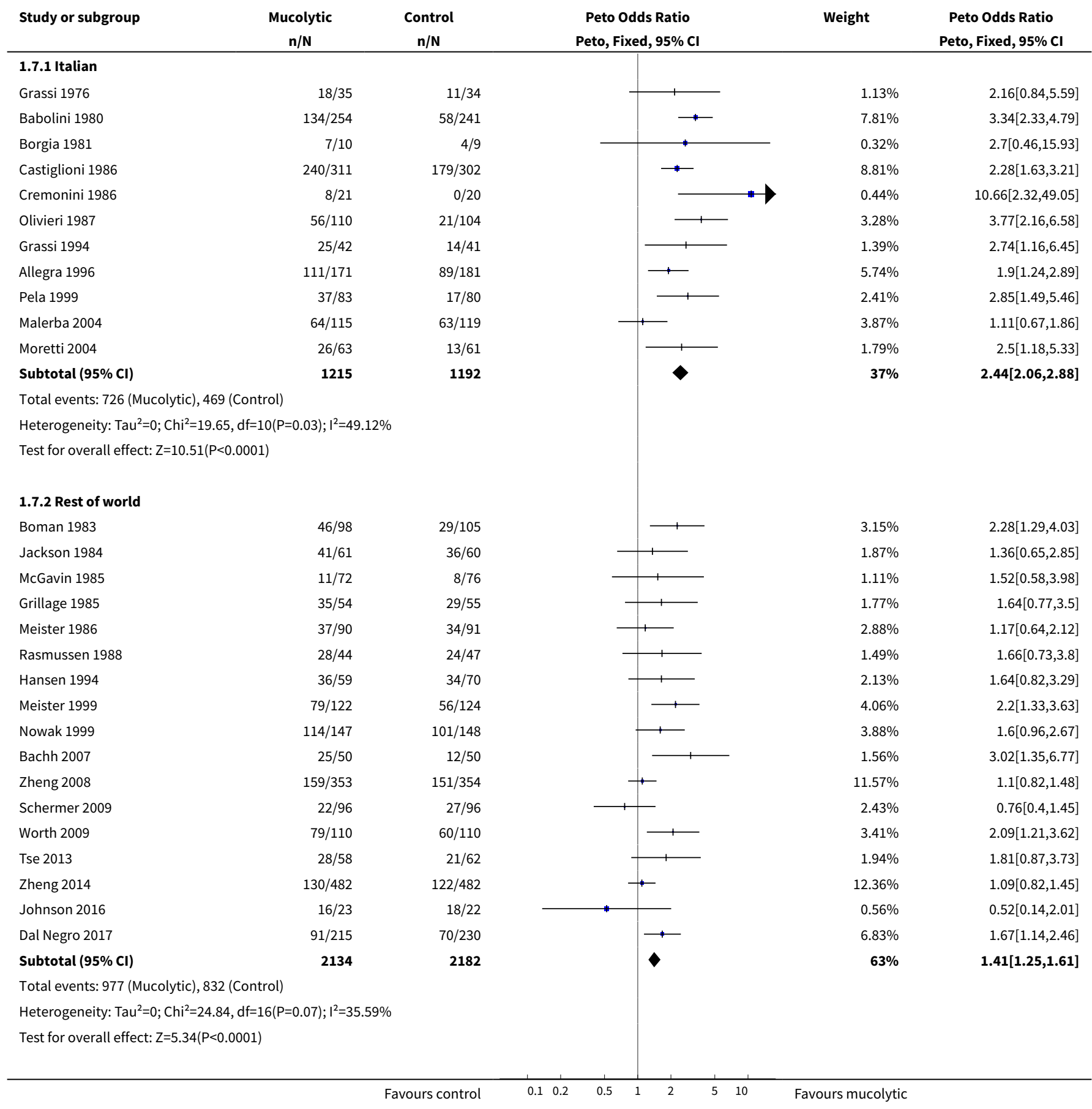




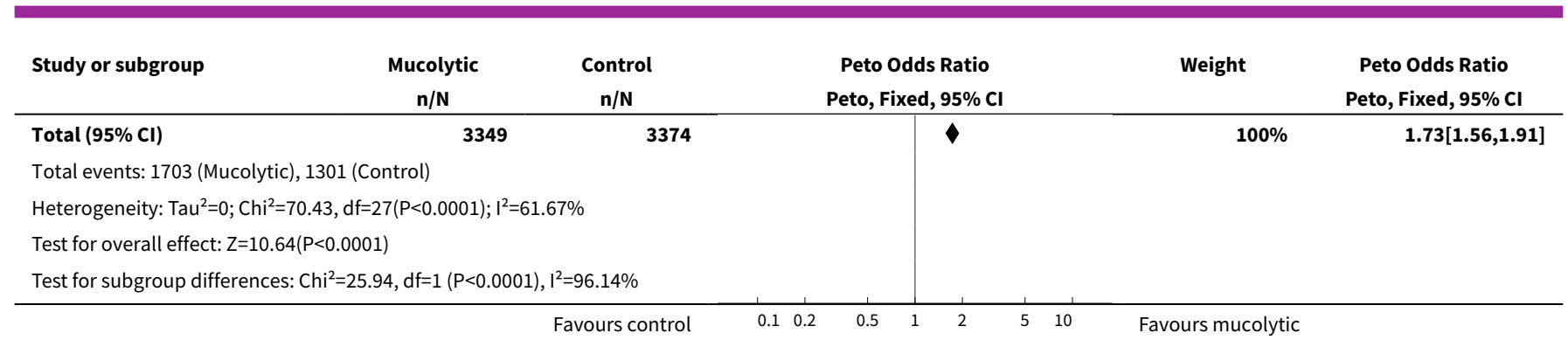

\section{Analysis 1.8. Comparison 1 Mucolytic versus placebo, Outcome 8 Participants with no exacerbations in study period - by history of exacerbation.}

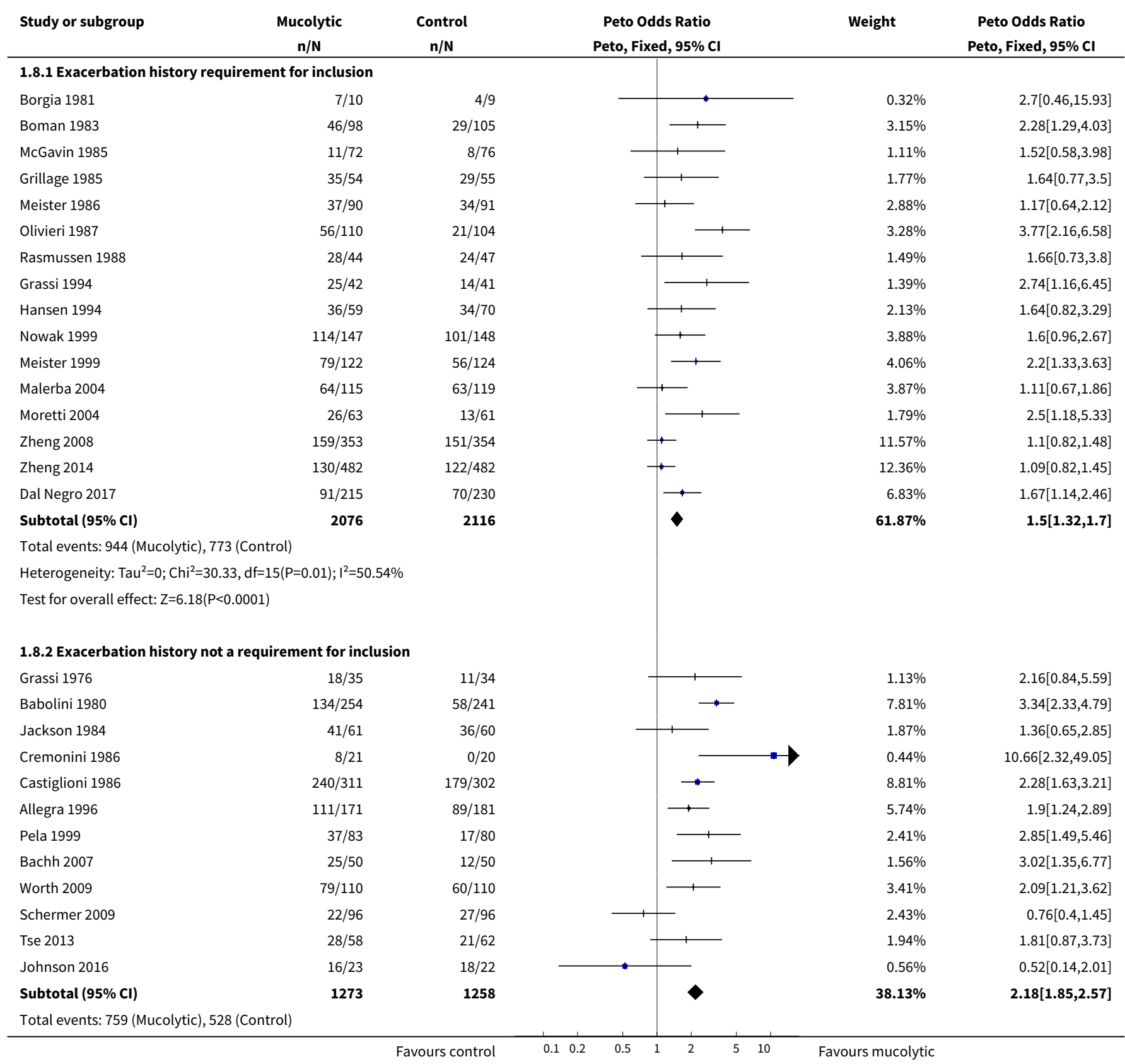




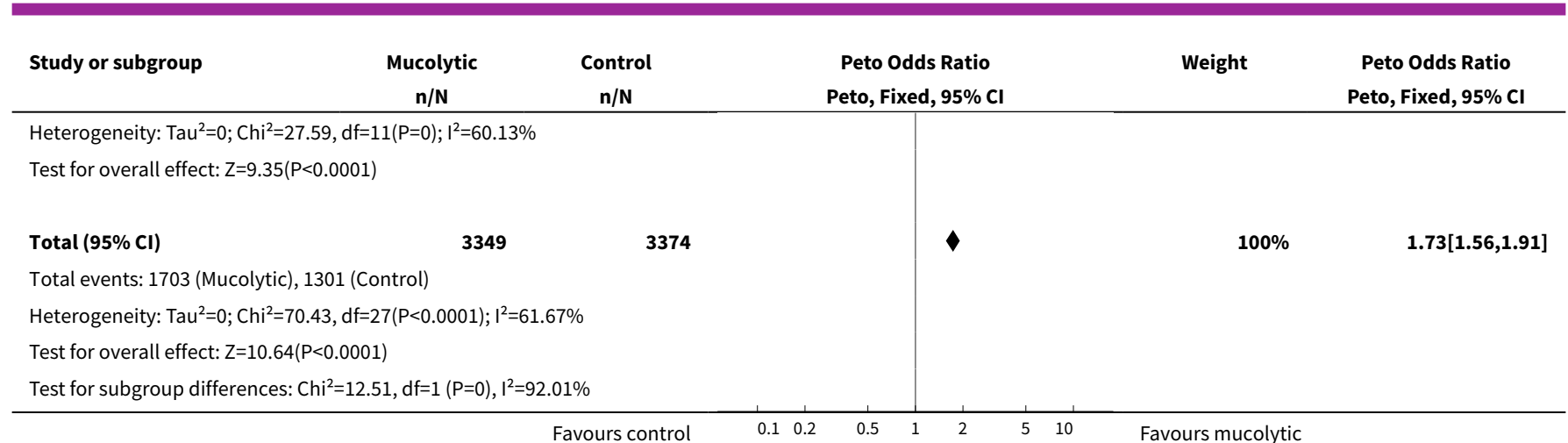

Analysis 1.9. Comparison 1 Mucolytic versus placebo, Outcome 9 Participants with no exacerbations in study period - by ICS use.

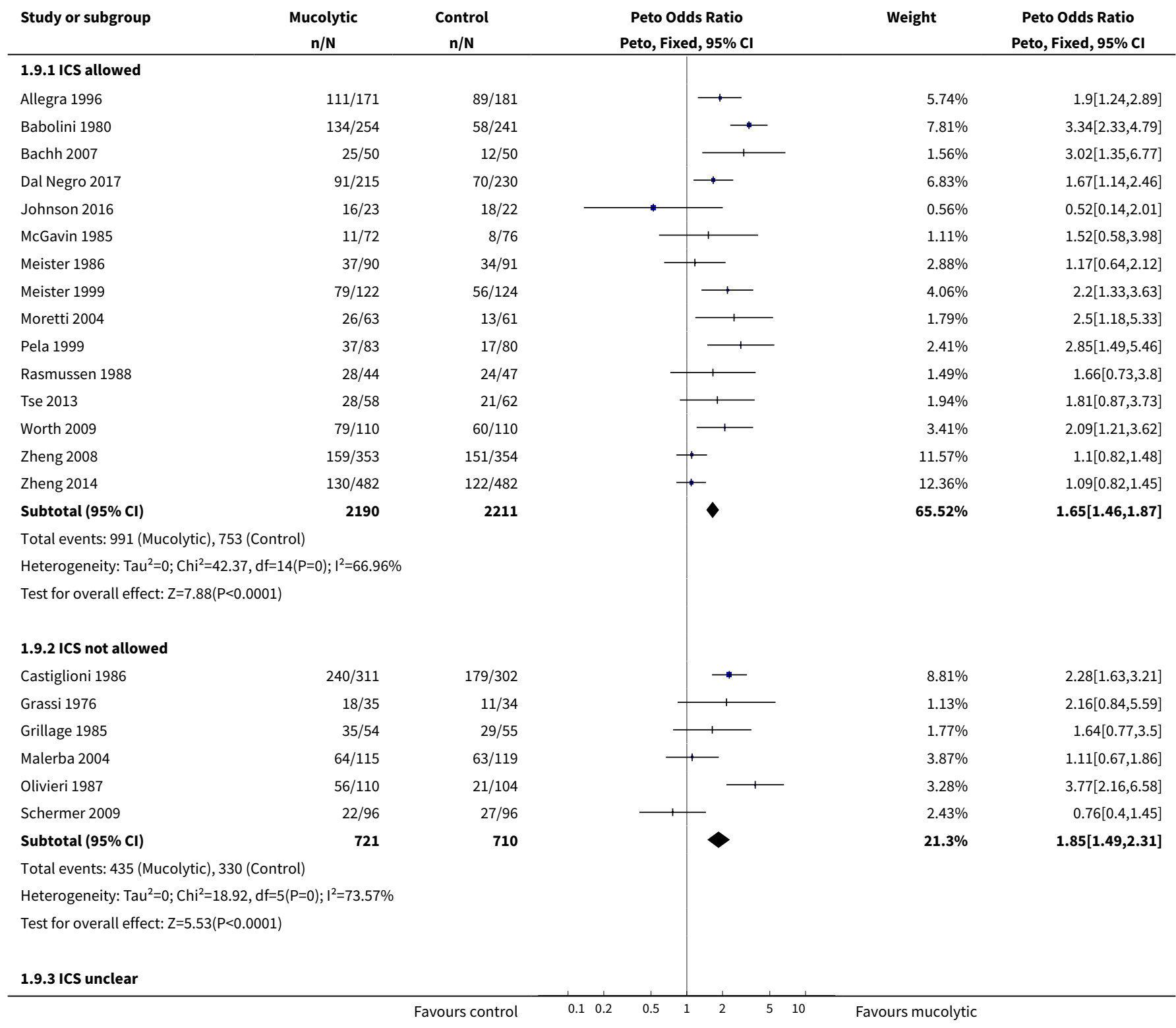




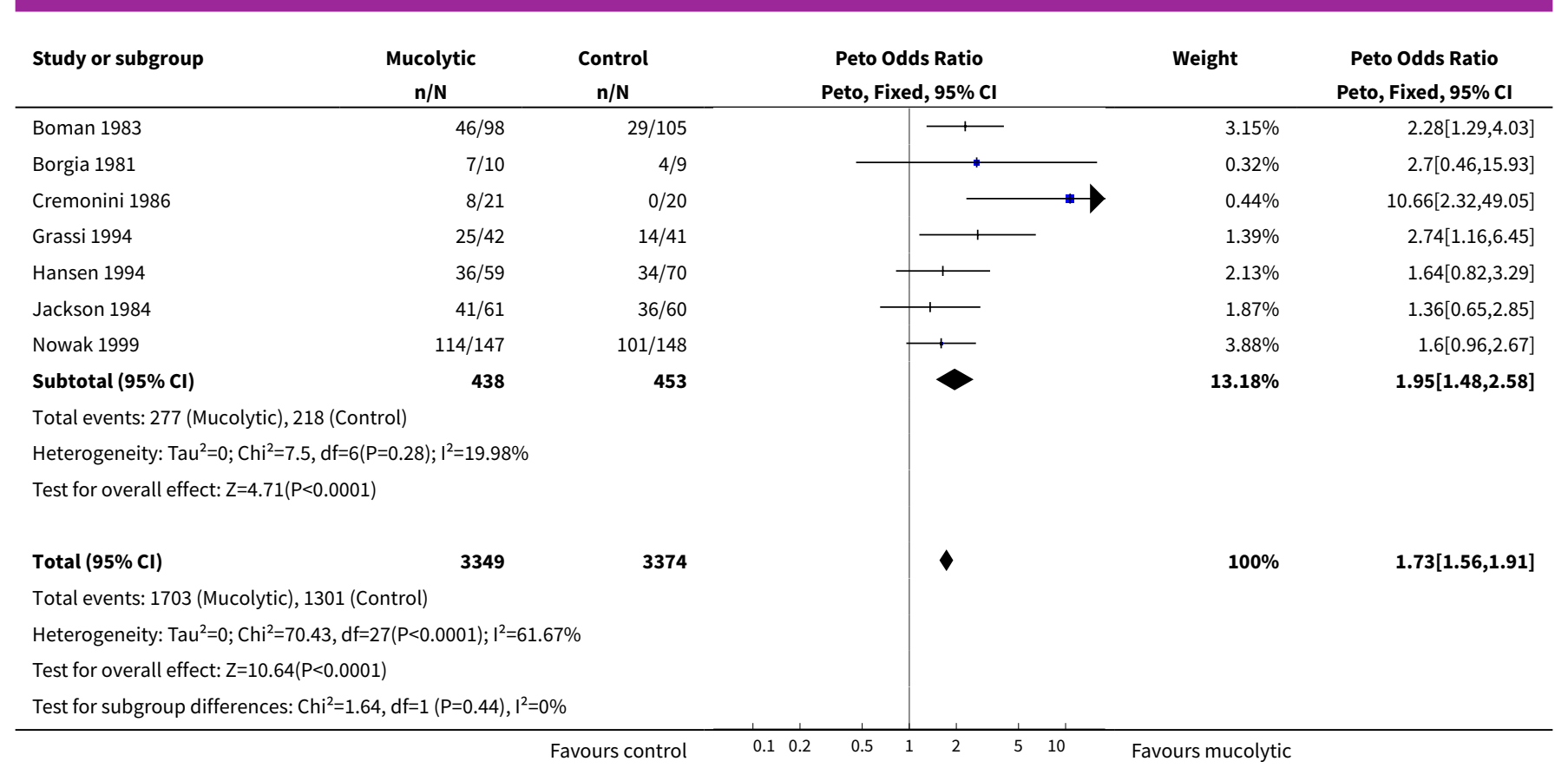

\section{Analysis 1.10. Comparison 1 Mucolytic versus placebo, Outcome 10 Number of exacerbations per participant per month.}

\begin{tabular}{|c|c|c|c|c|c|c|c|}
\hline \multicolumn{8}{|c|}{ Number of exacerbations per participant per month } \\
\hline Study & $\begin{array}{c}\text { Mean mu- } \\
\text { colytic group }\end{array}$ & SD & $\mathbf{N}$ & $\begin{array}{l}\text { Mean con- } \\
\text { trol group }\end{array}$ & SD & $\mathbf{N}$ & $\begin{array}{c}\text { Mean differ- } \\
\text { ence }[95 \% \mathrm{Cl}]\end{array}$ \\
\hline Allegra 1996 & 0.07 & 0.11 & 223 & 0.11 & 0.14 & 218 & $-0.04[-0.06,-0.02]$ \\
\hline Babolini 1980 & 0.13 & 0.18 & 254 & 0.33 & 0.27 & 241 & $-0.20[-0.24,-0.16]$ \\
\hline Boman 1983 & 0.2 & 0.27 & 98 & 0.32 & 0.3 & 105 & $-0.12[-0.20,-0.04]$ \\
\hline Borgia 1981 & 0.05 & 0.08 & 10 & 0.15 & 0.17 & 9 & $-0.10[-0.22,0.02]$ \\
\hline Castiglioni 1986 & 0.1 & 0.21 & 311 & 0.2 & 0.29 & 302 & $-0.10[-0.14,-0.06]$ \\
\hline Cremonini 1986 & 0.25 & 0.23 & 21 & 0.71 & 0.29 & 20 & $-0.46[-0.62,-0.30]$ \\
\hline Decramer 2005 & 0.1 & 0.11 & 256 & 0.11 & 0.16 & 267 & $-0.01[-0.03,0.01]$ \\
\hline Fukuchi 2016 & 0.15 & 0.24 & 201 & 0.13 & 0.21 & 204 & $0.02[-0.02,0.06]$ \\
\hline Grassi 1976 & 0.14 & 0.15 & 35 & 0.27 & 0.21 & 34 & $-0.13[-0.22,-0.04]$ \\
\hline Grassi 1994 & 0.16 & 0.29 & 42 & 0.45 & 0.43 & 41 & $-0.29[-0.45,-0.13]$ \\
\hline Grillage 1985 & 0.1 & 0.12 & 54 & 0.12 & 0.15 & 55 & $-0.02[-0.07,0.03]$ \\
\hline Hansen 1994 & 0.11 & 0.15 & 59 & 0.16 & 0.19 & 70 & $-0.05[-0.11,0.01]$ \\
\hline Jackson 1984 & 0.11 & 0.14 & 61 & 0.13 & 0.16 & 60 & $-0.02[-0.07,0.03]$ \\
\hline Malerba 2004 & 0.06 & 0.08 & 115 & 0.07 & 0.08 & 119 & $-0.01[-0.03,0.01]$ \\
\hline McGavin 1985 & 0.42 & 0.34 & 72 & 0.52 & 0.35 & 76 & $-0.10[-0.21,0.01]$ \\
\hline Meister 1986 & 0.15 & 0.15 & 90 & 0.2 & 0.19 & 91 & $-0.05[-0.10,-0.00]$ \\
\hline Meister 1999 & 0.06 & 0.15 & 122 & 0.1 & 0.15 & 124 & $-0.04[-0.08,-0.00]$ \\
\hline Moretti 2004 & 0.12 & 0.14 & 63 & 0.17 & 0.17 & 61 & $-0.05[-0.10,0.00]$ \\
\hline Nowak 1999 & 0.03 & 0.06 & 147 & 0.06 & 0.12 & 148 & $-0.03[-0.05,-0.01]$ \\
\hline Olivieri 1987 & 0.18 & 0.31 & 110 & 0.33 & 0.41 & 104 & $-0.15[-0.25,-0.05]$ \\
\hline Parr 1987 & 0.18 & 0.21 & 243 & 0.21 & 0.21 & 210 & $-0.03[-0.07,0.01]$ \\
\hline Pela 1999 & 0.14 & 0.15 & 35 & 0.27 & 0.21 & 34 & $-0.13[-0.22,-0.04]$ \\
\hline Rasmussen 1988 & 0.13 & 0.21 & 44 & 0.14 & 0.19 & 47 & $-0.01[-0.09,0.07]$ \\
\hline Schermer 2009 & 0.08 & 0.1 & 96 & 0.06 & 0.05 & 96 & $0.02[-0.00,0.04]$ \\
\hline Tse 2013 & 0.08 & 0.24 & 58 & 0.14 & 0.24 & 62 & $-0.06[-0.15,0.03]$ \\
\hline Worth 2009 & 0.067 & 0.136 & 110 & 0.15 & 0.24 & 110 & $-0.08[-0.13,-0.03]$ \\
\hline Zheng 2008 & 0.084 & 0.094 & 353 & 0.11 & 0.094 & 354 & $-0.03[-0.04,-0.01]$ \\
\hline
\end{tabular}

Mucolytic agents versus placebo for chronic bronchitis or chronic obstructive pulmonary disease (Review) 


\begin{tabular}{|c|c|c|c|c|c|c|c|}
\hline \multicolumn{8}{|c|}{ Number of exacerbations per participant per month } \\
\hline Study & $\begin{array}{l}\text { Mean mu- } \\
\text { colytic group }\end{array}$ & SD & $\mathbf{N}$ & $\begin{array}{l}\text { Mean con- } \\
\text { trol group }\end{array}$ & SD & $\mathbf{N}$ & $\begin{array}{c}\text { Mean differ- } \\
\text { ence }[95 \% \mathrm{Cl}]\end{array}$ \\
\hline Zheng 2014 & 0.1 & 0.15 & 482 & 0.13 & 0.17 & 482 & $-0.03[-0.05,-0.01]$ \\
\hline
\end{tabular}

Analysis 1.11. Comparison 1 Mucolytic versus placebo, Outcome 11 Days of disability per participant per month.

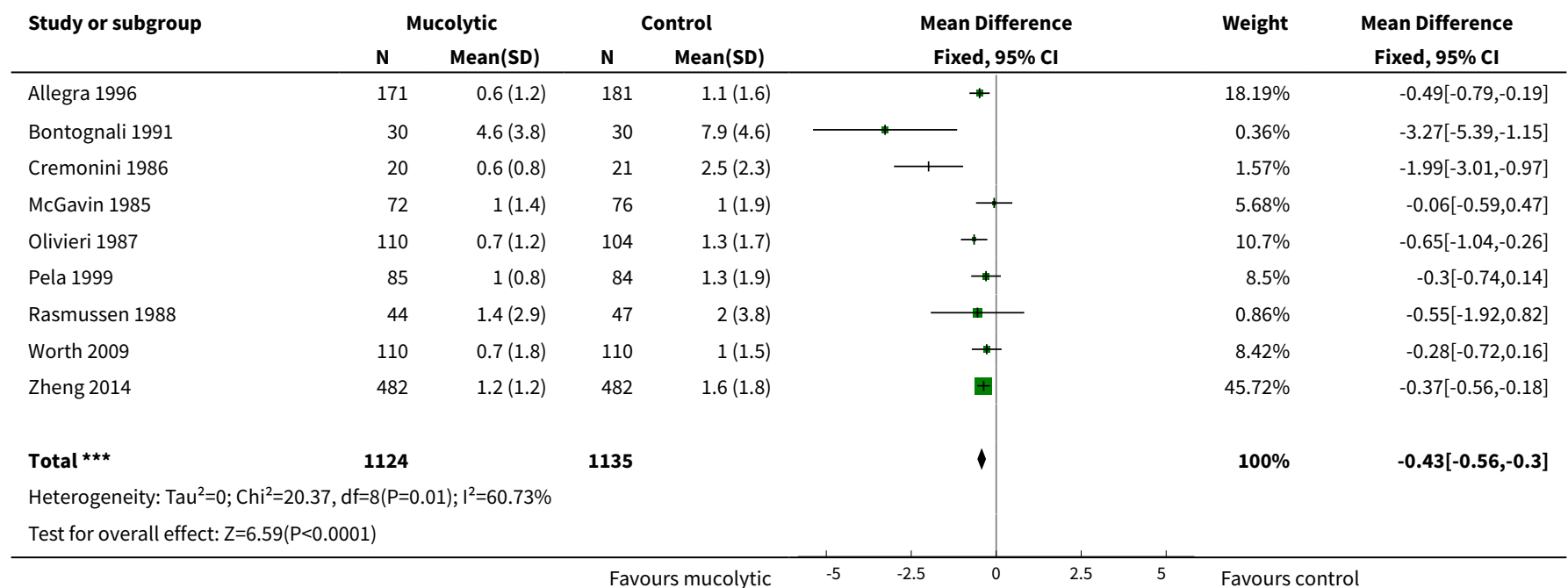

Analysis 1.12. Comparison 1 Mucolytic versus placebo, Outcome 12 Days on antibiotics per participant per month.

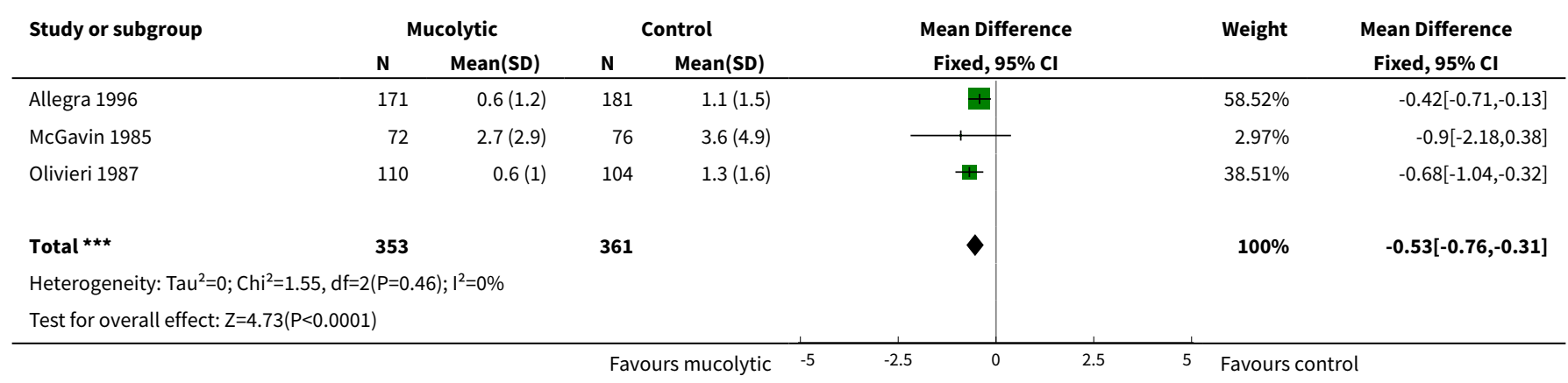

Analysis 1.13. Comparison 1 Mucolytic versus placebo, Outcome $13 \mathrm{FEV}_{1}$ at end of study.

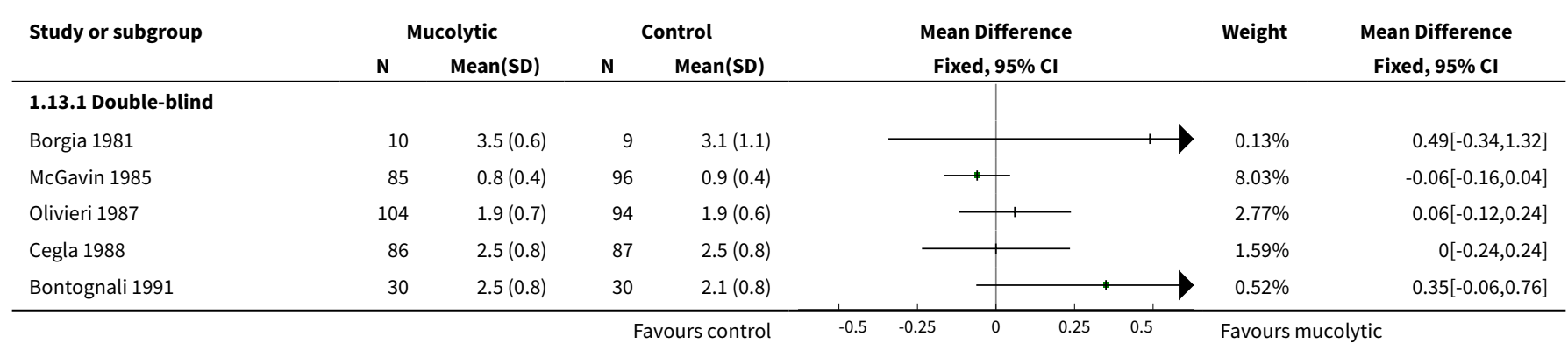




\begin{tabular}{|c|c|c|c|c|c|c|c|c|c|}
\hline \multirow{3}{*}{$\begin{array}{l}\text { Study or subgroup } \\
\text { Moretti } 2004\end{array}$} & \multicolumn{2}{|c|}{ Mucolytic } & \multicolumn{2}{|c|}{ Control } & \multirow{2}{*}{\multicolumn{3}{|c|}{$\begin{array}{c}\text { Mean Difference } \\
\text { Fixed, } 95 \% \mathrm{Cl}\end{array}$}} & \multirow{3}{*}{$\begin{array}{l}\text { Weight } \\
7.92 \%\end{array}$} & \multirow{3}{*}{$\begin{array}{c}\text { Mean Difference } \\
\text { Fixed, } 95 \% \text { Cl } \\
0.33[0.22,0.44]\end{array}$} \\
\hline & \multirow{2}{*}{$\frac{\mathbf{N}}{63}$} & \multirow{2}{*}{$\frac{\operatorname{Mean}(\mathrm{SD})}{1.8(0.3)}$} & \multirow{2}{*}{$\frac{\mathbf{N}}{61}$} & \multirow{2}{*}{$\frac{\operatorname{Mean}(\mathbf{S D})}{1.5(0.3)}$} & & & & & \\
\hline & & & & & & & $\longrightarrow$ & & \\
\hline Decramer 2005 & 248 & $1.6(0.4)$ & 258 & $1.6(0.4)$ & & & & $19.66 \%$ & $0[-0.07,0.07]$ \\
\hline Schermer 2009 & 96 & $2.1(0.7)$ & 96 & $2.1(0.7)$ & & & & $2.35 \%$ & $-0.05[-0.24,0.14]$ \\
\hline Worth 2009 & 110 & $1.7(0.6)$ & 110 & $1.6(0.5)$ & & & & $4.15 \%$ & $0.09[-0.06,0.24]$ \\
\hline Tse 2013 & 58 & $1.4(0.6)$ & 62 & $1.3(0.6)$ & & & - & $2.08 \%$ & $0.09[-0.12,0.3]$ \\
\hline Zheng 2014 & 504 & $1.2(0.4)$ & 502 & $1.2(0.4)$ & & & & $31.32 \%$ & $0.01[-0.04,0.06]$ \\
\hline Johnson 2016 & 23 & $1.1(0.4)$ & 21 & $1.1(0.5)$ & & & & $1.27 \%$ & $0.02[-0.24,0.28]$ \\
\hline Dal Negro 2017 & 228 & $1.4(0.4)$ & 239 & $1.4(0.5)$ & & & & $15.56 \%$ & $0.03[-0.05,0.11]$ \\
\hline 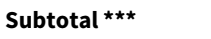 & 1645 & & 1665 & & & & & $97.35 \%$ & $0.04[0.01,0.07]$ \\
\hline \multicolumn{10}{|c|}{ Heterogeneity: $\operatorname{Tau}^{2}=0 ; \mathrm{Chi}^{2}=40.01, \mathrm{df}=12(\mathrm{P}<0.0001) ; \mathrm{I}^{2}=70.01 \%$} \\
\hline \multicolumn{10}{|c|}{ Test for overall effect: $Z=2.53(P=0.01)$} \\
\hline \multicolumn{10}{|l|}{ 1.13.2 Single-blind } \\
\hline Pela 1999 & 83 & $1.6(0.6)$ & 80 & $1.5(0.6)$ & & & - & $2.65 \%$ & $0.08[-0.1,0.26]$ \\
\hline Subtotal $\star \star \star$ & 83 & & 80 & & & & & $2.65 \%$ & $0.08[-0.1,0.26]$ \\
\hline \multicolumn{10}{|c|}{ Heterogeneity: Not applicable } \\
\hline \multicolumn{10}{|c|}{ Test for overall effect: $Z=0.86(P=0.39)$} \\
\hline 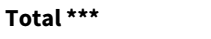 & 1728 & & 1745 & & & & & $100 \%$ & $0.04[0.01,0.07]$ \\
\hline \multicolumn{10}{|c|}{ Heterogeneity: $\mathrm{Tau}^{2}=0 ; \mathrm{Chi}^{2}=40.2, \mathrm{df}=13(\mathrm{P}=0) ; \mathrm{I}^{2}=67.66 \%$} \\
\hline \multicolumn{10}{|c|}{ Test for overall effect: $Z=2.64(P=0.01)$} \\
\hline Test for subgroup dif & $.19, \mathrm{df}=$ & $P=0.66), I^{2}=0$ & & & & & & & \\
\hline
\end{tabular}

Analysis 1.14. Comparison 1 Mucolytic versus placebo, Outcome 14 Percent predicted FEV 1 .

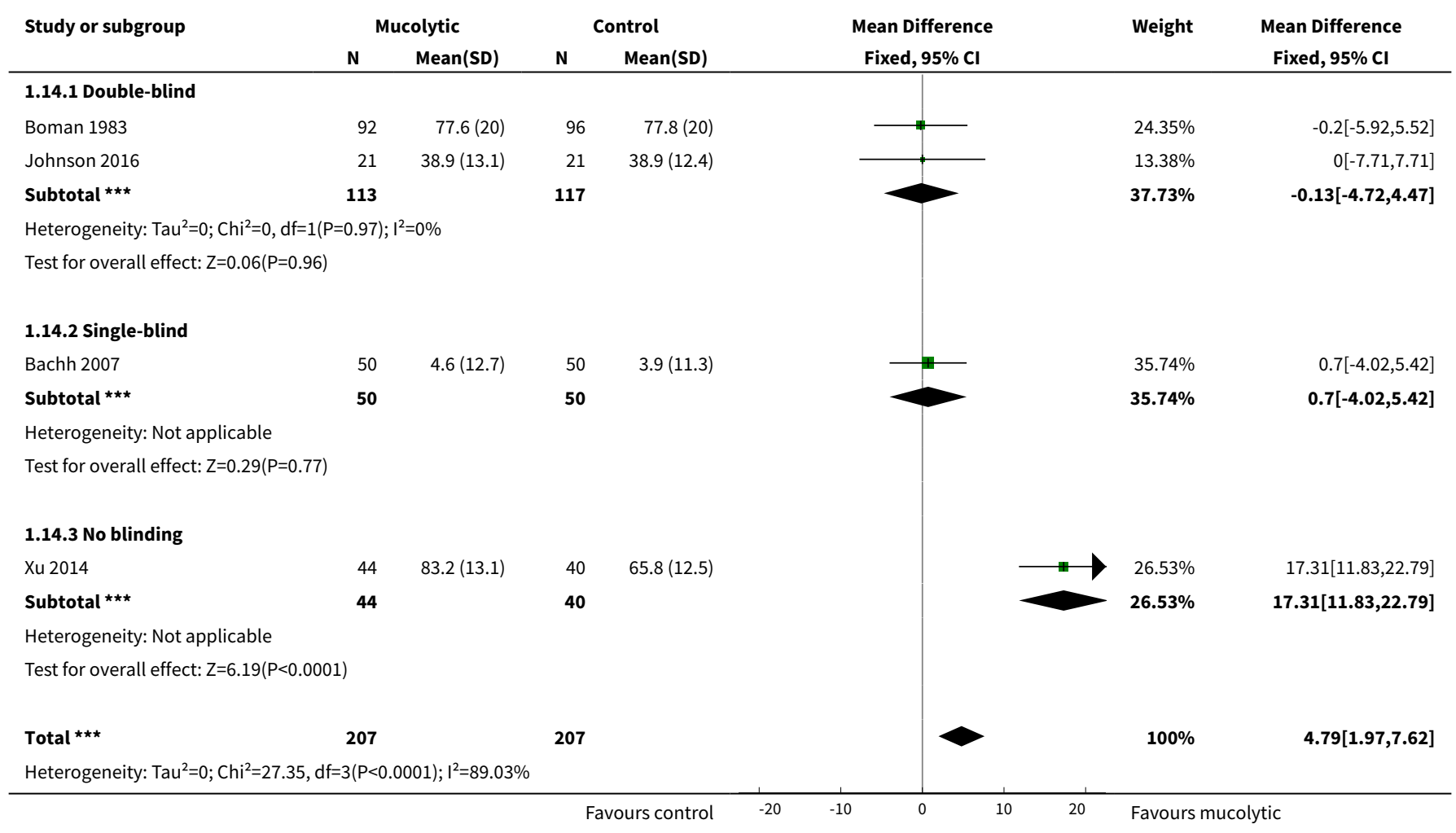




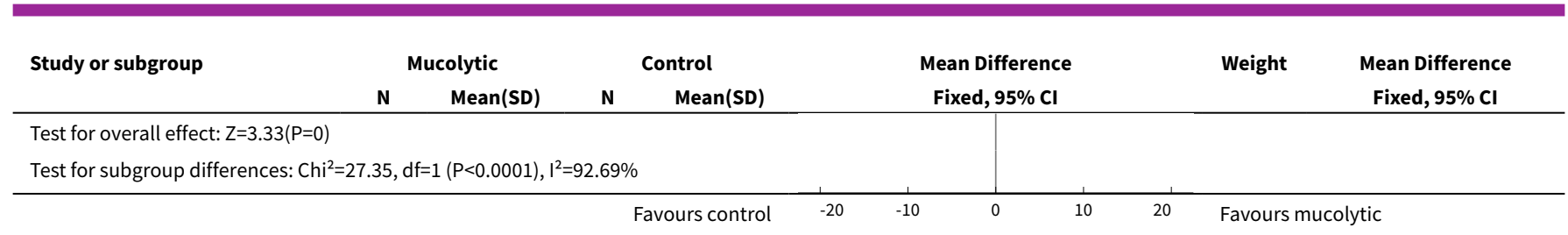

Analysis 1.15. Comparison 1 Mucolytic versus placebo, Outcome 15 PEFR at end of study.

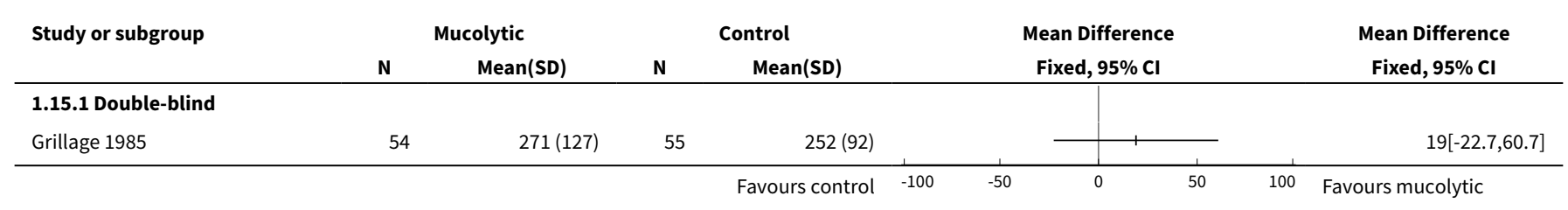

Analysis 1.16. Comparison 1 Mucolytic versus placebo, Outcome $16 \mathrm{FVC}$ at end of study.

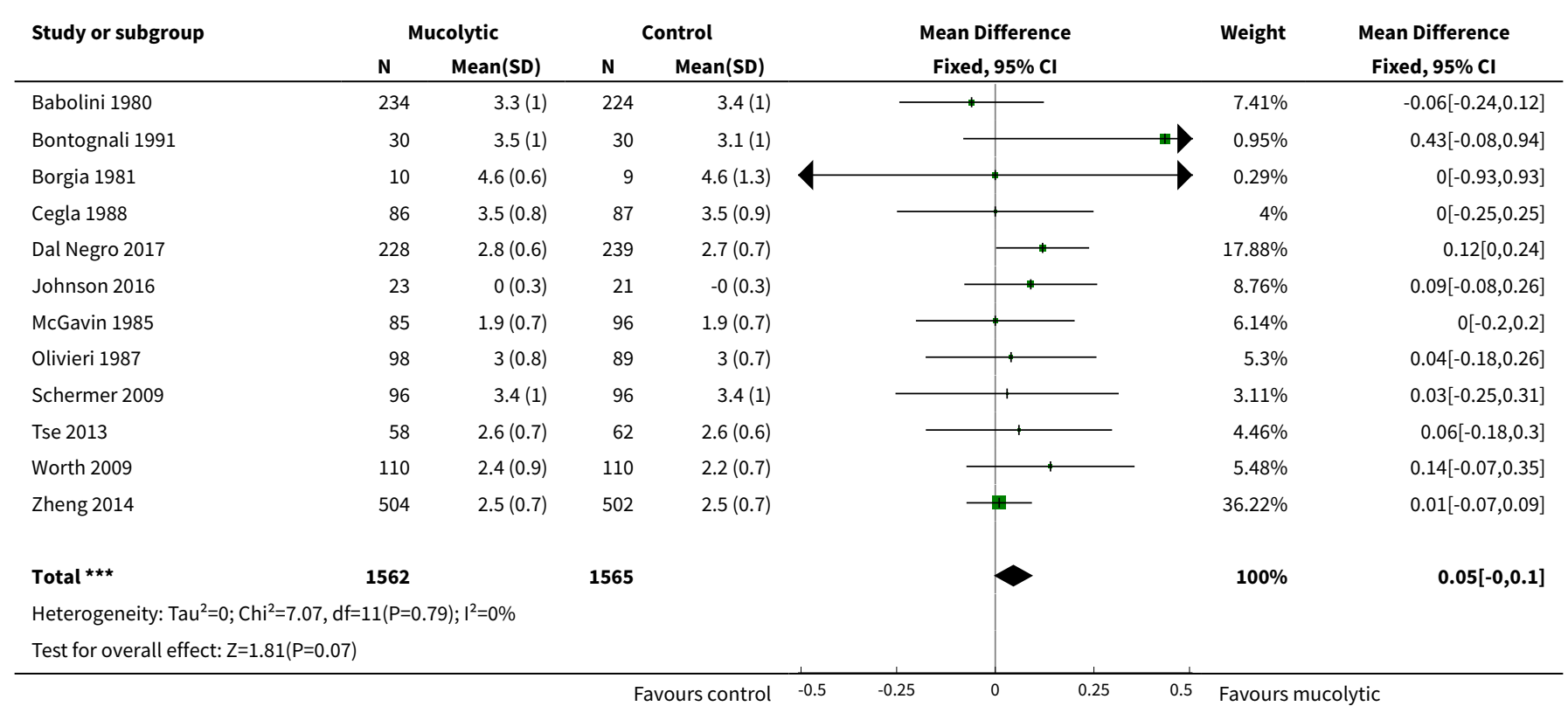

Analysis 1.17. Comparison 1 Mucolytic versus placebo, Outcome 17 Adverse effects.

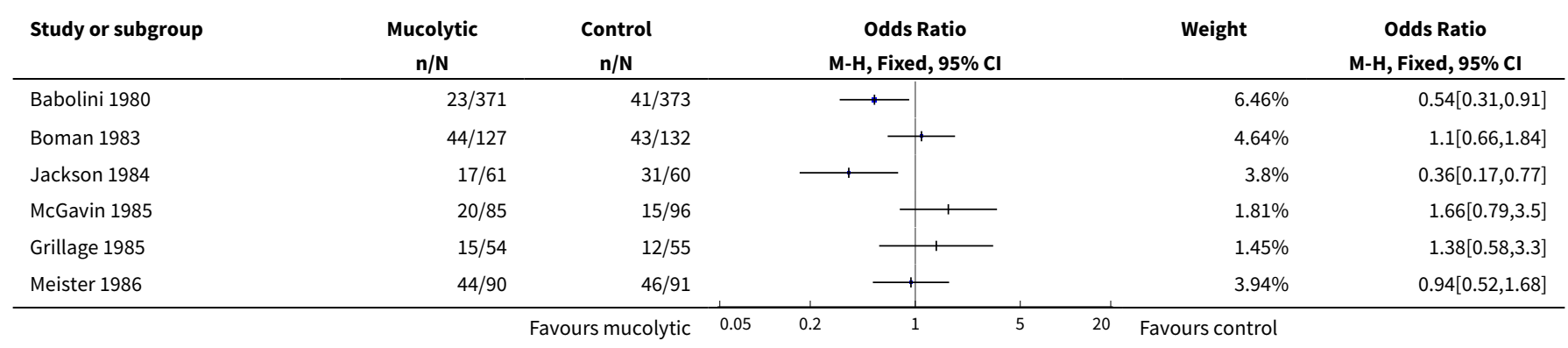




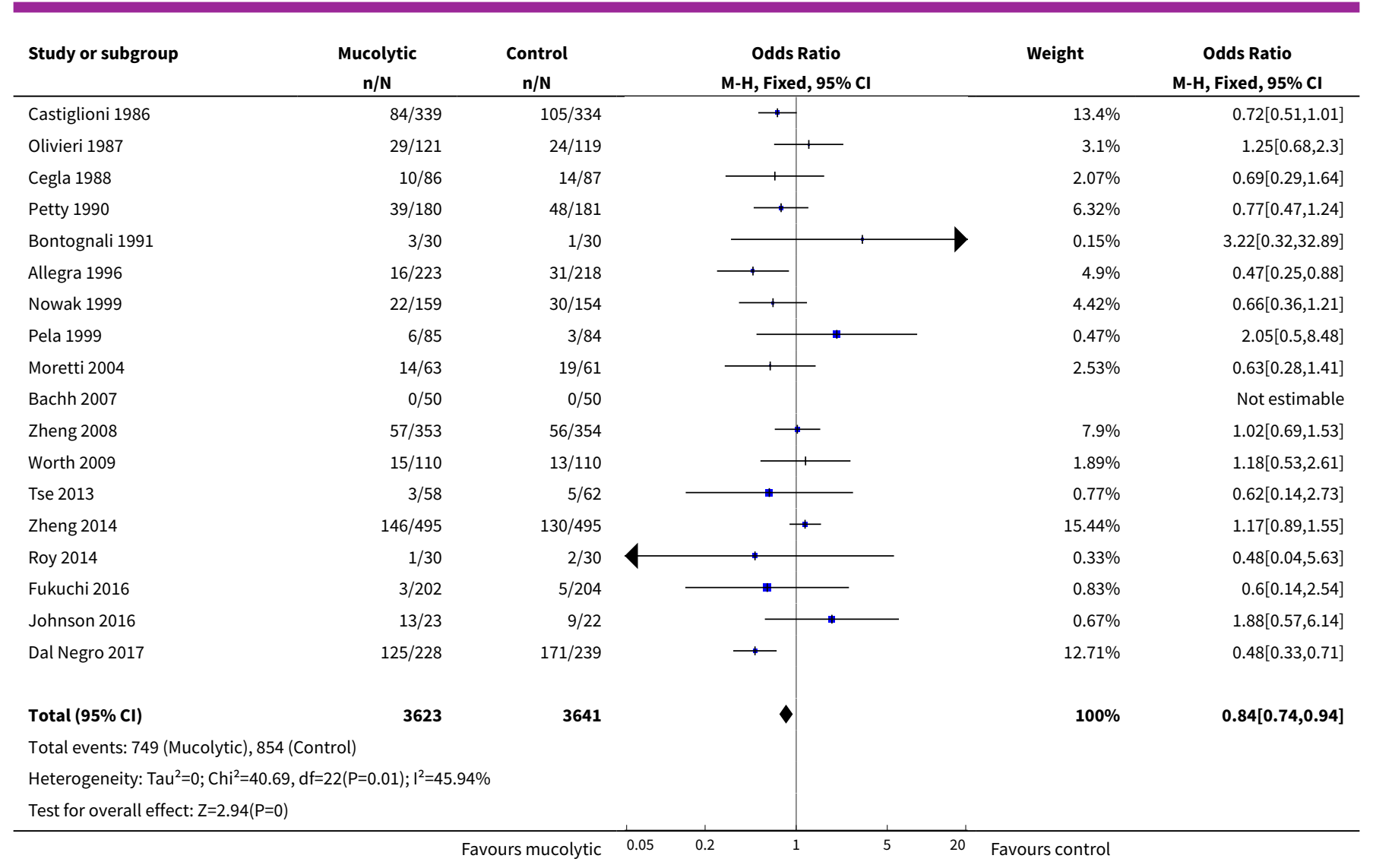

Analysis 1.18. Comparison 1 Mucolytic versus placebo, Outcome 18 Hospitalisation during study period.

\begin{tabular}{|c|c|c|c|c|c|}
\hline Study or subgroup & $\begin{array}{c}\text { Mucolytic } \\
\mathrm{n} / \mathrm{N}\end{array}$ & $\begin{array}{c}\text { Control } \\
n / N\end{array}$ & $\begin{array}{c}\text { Peto Odds Ratio } \\
\text { Peto, Fixed, } 95 \% \mathrm{Cl}\end{array}$ & Weight & $\begin{array}{c}\text { Peto Odds Ratio } \\
\text { Peto, Fixed, } 95 \% \mathrm{Cl}\end{array}$ \\
\hline Decramer 2005 & $55 / 256$ & $69 / 267$ & 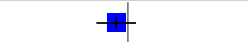 & $43.77 \%$ & $0.79[0.53,1.18]$ \\
\hline Moretti 2004 & $10 / 79$ & $19 / 76$ & $\longrightarrow$ & $10.96 \%$ & $0.45[0.2,1]$ \\
\hline Zheng 2014 & $33 / 495$ & $36 / 495$ & $\rightarrow-$ & $29.68 \%$ & $0.91[0.56,1.49]$ \\
\hline Tse 2013 & $26 / 58$ & $45 / 62$ & $\longrightarrow$ & $13.49 \%$ & $0.32[0.15,0.66]$ \\
\hline Johnson 2016 & $2 / 23$ & $3 / 22$ & - & $2.1 \%$ & $0.61[0.1,3.86]$ \\
\hline Total $(95 \% \mathrm{Cl})$ & 911 & 922 & $\nabla$ & $100 \%$ & $0.68[0.52,0.89]$ \\
\hline \multicolumn{6}{|c|}{ Total events: 126 (Mucolytic), 172 (Control) } \\
\hline \multicolumn{6}{|c|}{ Heterogeneity: $\mathrm{Tau}^{2}=0 ; \mathrm{Chi}^{2}=7.08, \mathrm{df}=4(\mathrm{P}=0.13) ; \mathrm{I}^{2}=43.48 \%$} \\
\hline \multicolumn{6}{|c|}{ Test for overall effect: $Z=2.83(P=0)$} \\
\hline
\end{tabular}

Analysis 1.19. Comparison 1 Mucolytic versus placebo, Outcome 19 Death during study period.

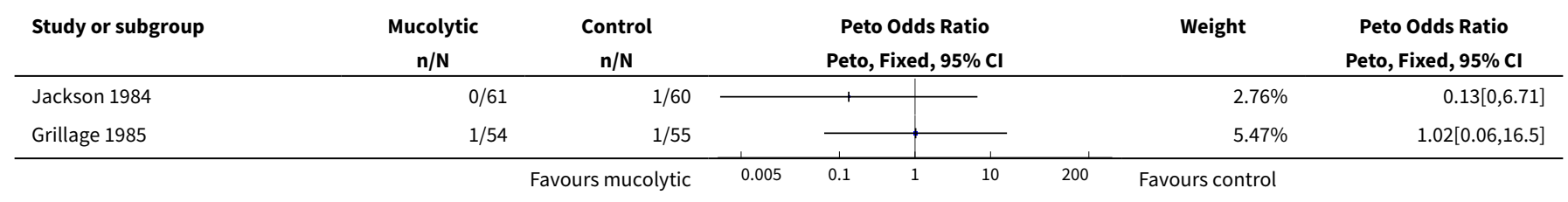




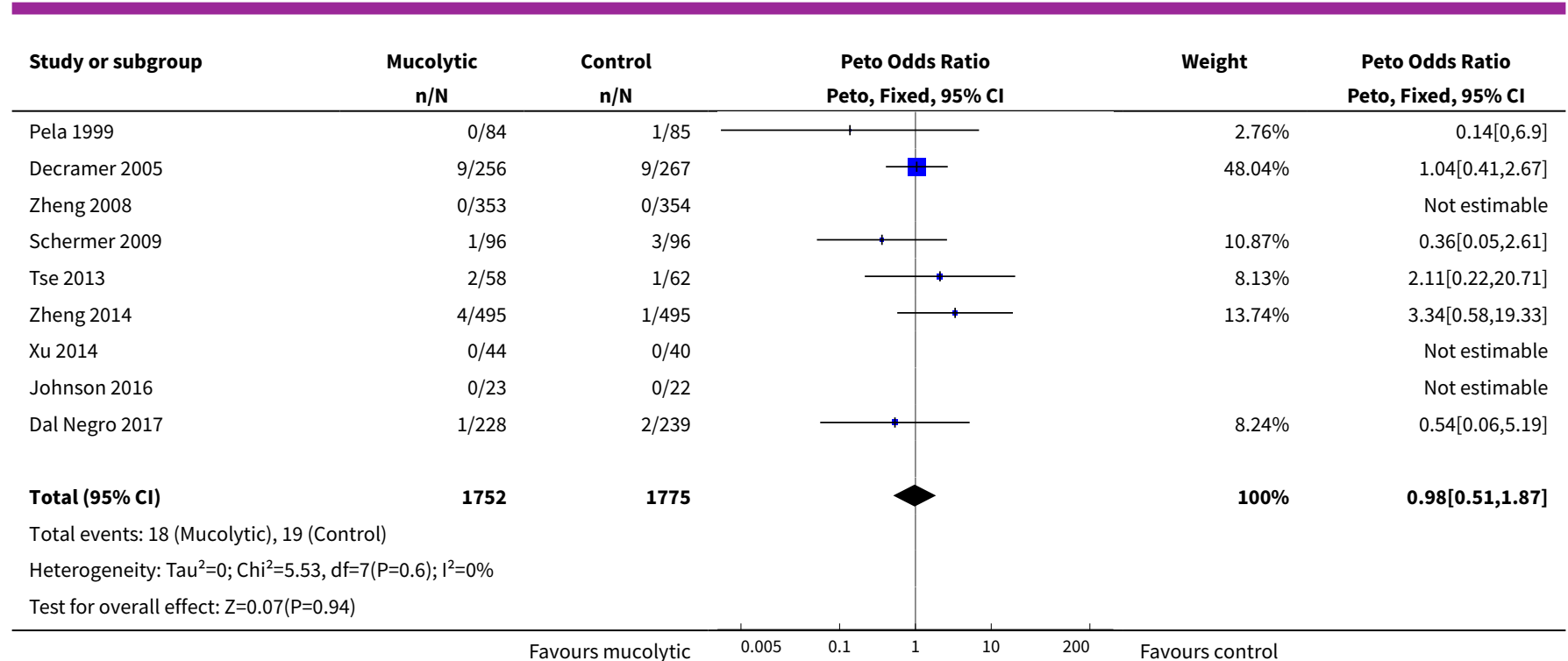

Analysis 1.20. Comparison 1 Mucolytic versus placebo, Outcome 20 Healthrelated quality of life (total score St. George's Respiratory Questionnaire).

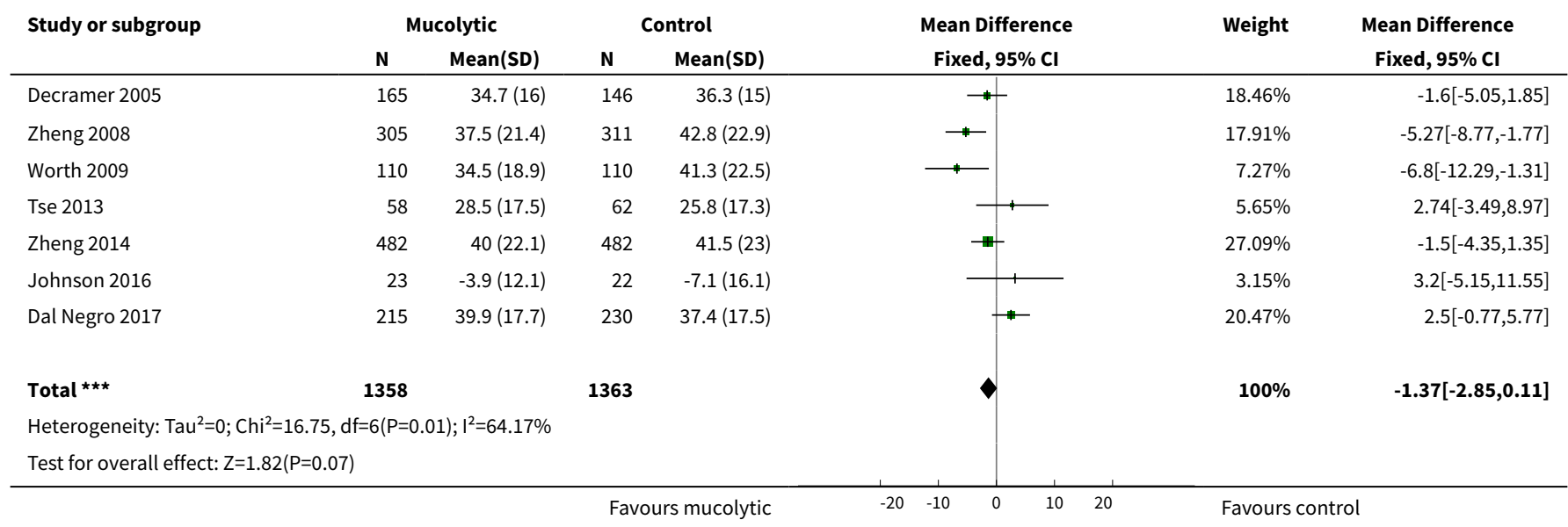

\section{Analysis 1.21. Comparison 1 Mucolytic versus placebo, Outcome 21 Health-related quality of life (total score COPD Assessment Test).}

\begin{tabular}{|c|c|c|c|c|c|c|c|c|c|}
\hline \multirow[t]{2}{*}{ Study or subgroup } & \multicolumn{2}{|c|}{ Mucolytic } & \multicolumn{2}{|c|}{ Control } & & \multirow{2}{*}{\multicolumn{2}{|c|}{$\begin{array}{c}\text { Mean Difference } \\
\text { Fixed, } 95 \% \mathrm{Cl}\end{array}$}} & \multirow[t]{2}{*}{ Weight } & \multirow{2}{*}{$\begin{array}{c}\text { Mean Difference } \\
\text { Fixed, } 95 \% \mathrm{Cl}\end{array}$} \\
\hline & $\mathbf{N}$ & Mean(SD) & $\mathbf{N}$ & Mean(SD) & & & & & \\
\hline Fukuchi 2016 & 171 & $-2.9(6.3)$ & 169 & $-2(6.1)$ & & & - & $0 \%$ & $-0.9[-2.22,0.42]$ \\
\hline
\end{tabular}


Comparison 2. Systemic thiol donor versus placebo

\begin{tabular}{lllll}
\hline Outcome or subgroup title & No. of studies & $\begin{array}{l}\text { No. of partici- } \\
\text { pants }\end{array}$ & Statistical method & Effect size \\
\hline $\begin{array}{l}1 \text { Participants with no exacerbations in } \\
\text { the study period }\end{array}$ & 1 & 628 & $\begin{array}{l}\text { Peto Odds Ratio (Peto, } \\
\text { Fixed, 95\% Cl) }\end{array}$ & 1.01 [0.74, 1.39] \\
\hline $\begin{array}{l}\text { 2 Number of exacerbations per partici- } \\
\text { pant per month }\end{array}$ & 1 & Other data & No numeric data \\
\hline $\begin{array}{l}\text { 3 Days of disability per participant per } \\
\text { month }\end{array}$ & 1 & 628 & Mean Difference (IV, Fixed, & -0.18 [-0.82, 0.46] \\
\hline $\begin{array}{l}\text { 4 Adverse effects } \\
\text { 95\% Cl) }\end{array}$ & Peto Odds Ratio (Peto, \\
\hline
\end{tabular}

Analysis 2.1. Comparison 2 Systemic thiol donor versus placebo, Outcome 1 Participants with no exacerbations in the study period.

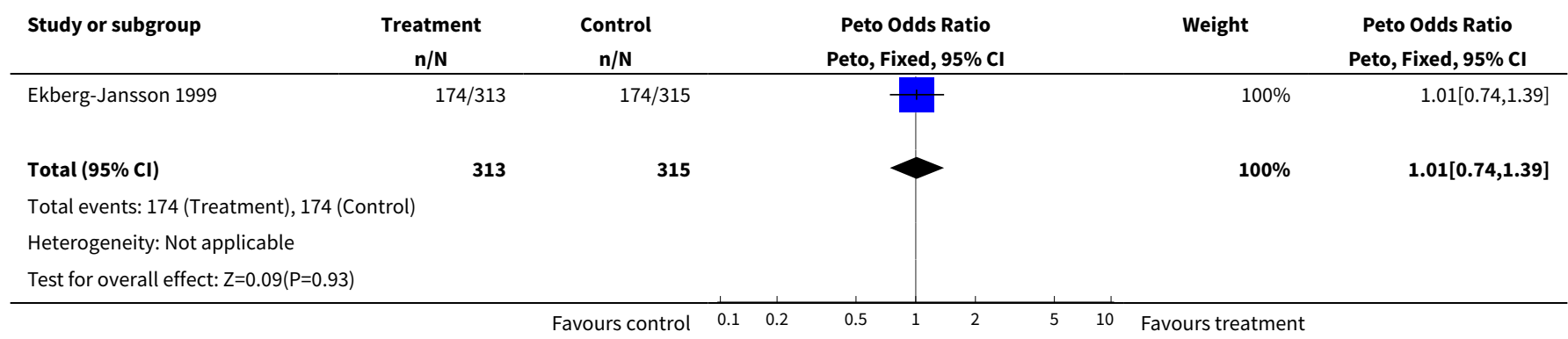

Analysis 2.2. Comparison 2 Systemic thiol donor versus placebo, Outcome 2 Number of exacerbations per participant per month.

\begin{tabular}{|c|c|c|c|c|c|c|c|}
\hline \multicolumn{8}{|c|}{ Number of exacerbations per participant per month } \\
\hline Study & $\begin{array}{c}\text { Mean mu- } \\
\text { colytic group }\end{array}$ & SD & $\mathbf{N}$ & $\begin{array}{l}\text { Mean con- } \\
\text { trol group }\end{array}$ & SD & $\mathbf{N}$ & $\begin{array}{c}\text { Mean differ- } \\
\text { ence }[95 \% \mathrm{Cl}]\end{array}$ \\
\hline $\begin{array}{l}\text { Ekberg-Jansson } \\
1999\end{array}$ & 0.18 & 0.22 & 313 & 0.17 & 0.21 & 315 & $0.01[-0.02,0.04]$ \\
\hline
\end{tabular}

Analysis 2.3. Comparison 2 Systemic thiol donor versus placebo, Outcome 3 Days of disability per participant per month.

\begin{tabular}{|c|c|c|c|c|c|c|c|}
\hline \multirow[t]{2}{*}{ Study or subgroup } & \multicolumn{2}{|c|}{ Treatment } & \multicolumn{2}{|c|}{ Control } & \multirow{2}{*}{$\begin{array}{c}\text { Mean Difference } \\
\text { Fixed, } 95 \% \mathrm{Cl}\end{array}$} & \multirow[t]{2}{*}{ Weight } & \multirow{2}{*}{$\begin{array}{c}\text { Mean Difference } \\
\text { Fixed, } 95 \% \mathrm{Cl}\end{array}$} \\
\hline & $\mathbf{N}$ & Mean(SD) & $\mathbf{N}$ & $\operatorname{Mean}(S D)$ & & & \\
\hline Ekberg-Jansson 1999 & 313 & $2.6(4)$ & 315 & $2.8(4.2)$ & 1 & $100 \%$ & $-0.18[-0.82,0.46]$ \\
\hline 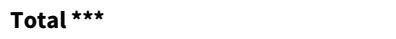 & 313 & & 315 & & & $100 \%$ & $-0.18[-0.82,0.46]$ \\
\hline \multicolumn{8}{|l|}{ Heterogeneity: Not applicable } \\
\hline Test for overall effect: $Z=0.55(P=0.58)$ & & & & & & & \\
\hline
\end{tabular}


Analysis 2.4. Comparison 2 Systemic thiol donor versus placebo, Outcome 4 Adverse effects.

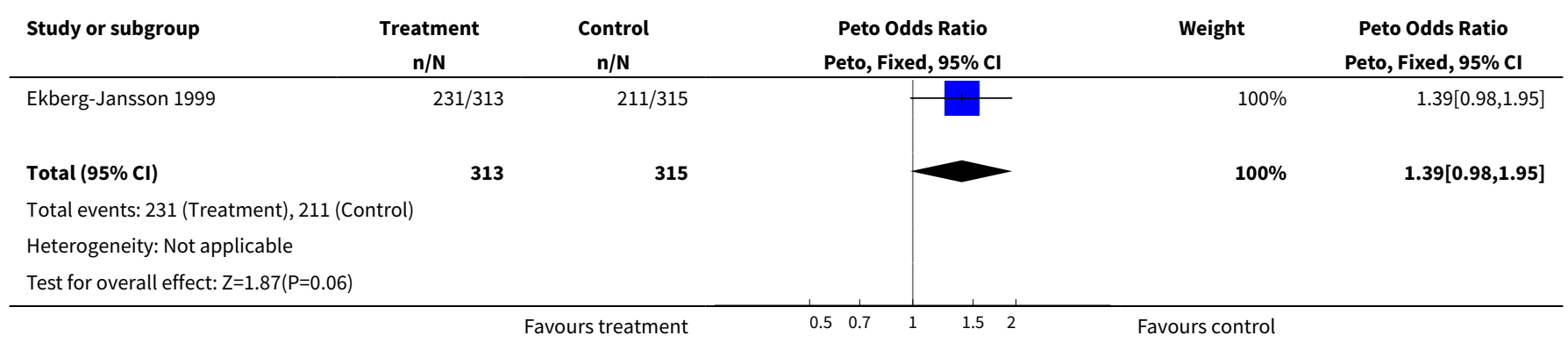




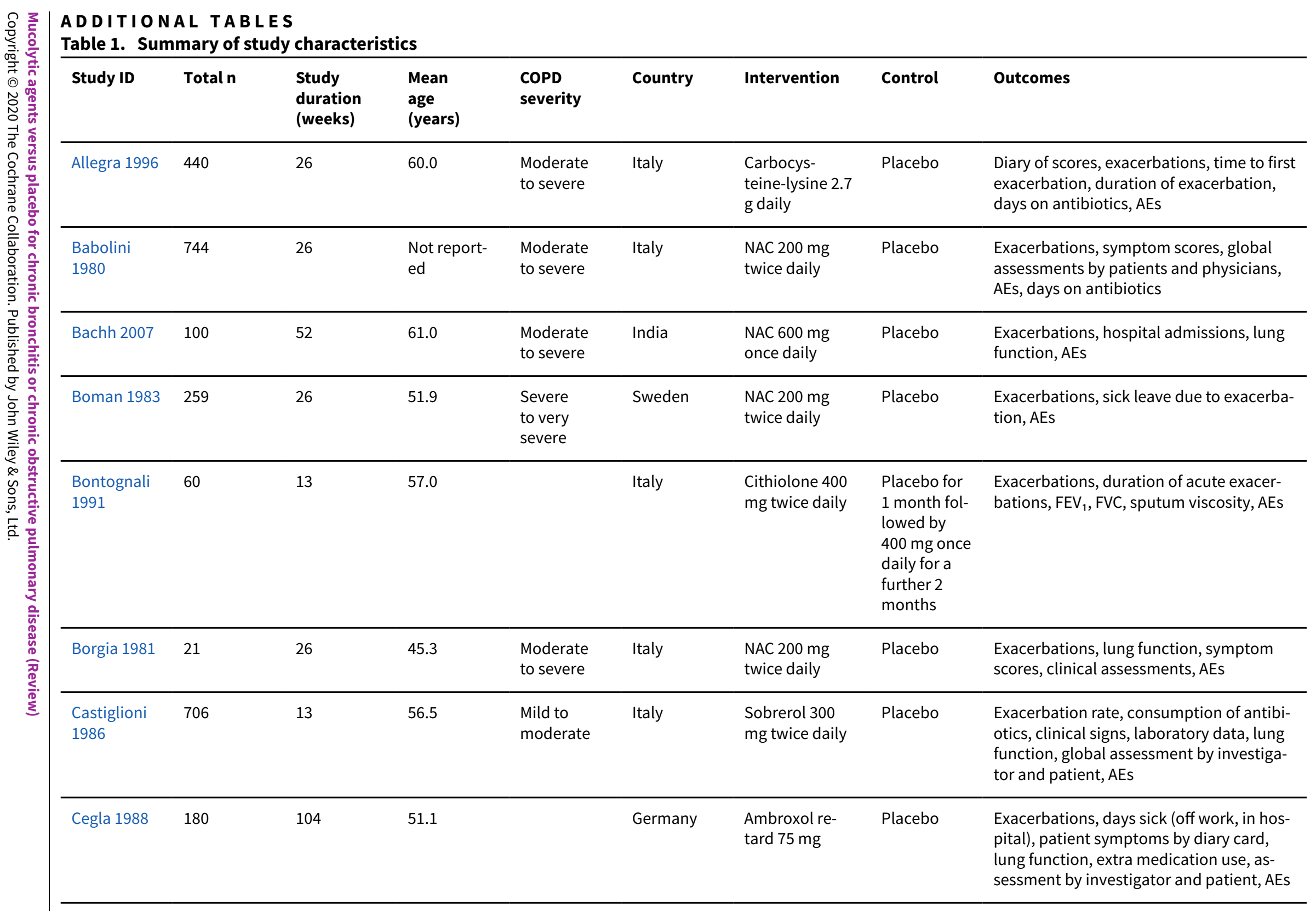




\begin{tabular}{|c|c|c|c|c|c|c|c|c|}
\hline $\begin{array}{l}\text { Cremonini } \\
1986\end{array}$ & 41 & 13 & 60.8 & & Italian & $\begin{array}{l}\text { Letosteine } 50 \\
\text { mg } 3 \text { times dai- } \\
\text { ly }\end{array}$ & Placebo & Exacerbations, days off sick, lung function \\
\hline $\begin{array}{l}\text { Dal Negro } \\
2017\end{array}$ & 467 & 52 & 64.8 & $\begin{array}{l}\text { Moderate } \\
\text { to severe }\end{array}$ & $\begin{array}{l}10 \text { European } \\
\text { countries }\end{array}$ & $\begin{array}{l}\text { Erdosteine } 300 \\
\text { mg twice daily }\end{array}$ & Placebo & $\begin{array}{l}\text { Number of acute exacerbations, spirom- } \\
\text { etry parameters, COPD symptoms, QoL, } \\
\text { safety and tolerability of erdosteine }\end{array}$ \\
\hline $\begin{array}{l}\text { De Backer } \\
2013\end{array}$ & 12 & 13 & 65.0 & $\begin{array}{l}\text { Moderate to } \\
\text { severe }\end{array}$ & Belgium & $\begin{array}{l}\text { NAC } 600 \mathrm{mg} 3 \\
\text { times daily }\end{array}$ & Placebo & $\begin{array}{l}\text { Spirometry, PEFR, raw, NO, specific air- } \\
\text { way resistance from plethysmography, } \\
\text { CT to look at airway geometry, serum glu- } \\
\text { tathione, enzymes, SGRQ, ABG }\end{array}$ \\
\hline $\begin{array}{l}\text { Decramer } \\
2005\end{array}$ & 523 & 156 & 62.0 & $\begin{array}{l}\text { Moderate } \\
\text { to severe }\end{array}$ & Europe & $\begin{array}{l}\text { NAC } 600 \mathrm{mg} \\
\text { daily }\end{array}$ & Placebo & $\begin{array}{l}\text { Lung function, exacerbation rate, QoL, } \\
\text { cost utility }\end{array}$ \\
\hline $\begin{array}{l}\text { Ek- } \\
\text { berg-Jans- } \\
\text { son } 1999\end{array}$ & 637 & 26 & 58.0 & $\begin{array}{l}\text { Mild, } \\
\text { moderate } \\
\text { to severe }\end{array}$ & Europe & $\begin{array}{l}\text { NIC } 300 \mathrm{mg} \\
\text { twice daily }\end{array}$ & Placebo & $\begin{array}{l}\text { Time to first exacerbation, exacerbation } \\
\text { rate, days sick (judged by patients and in- } \\
\text { vestigators), lung function, AEs }\end{array}$ \\
\hline $\begin{array}{l}\text { Fukuchi } \\
2016\end{array}$ & 408 & 52 & $\begin{array}{l}\text { Not report- } \\
\text { ed }\end{array}$ & $\begin{array}{l}\text { Moderate, } \\
\text { severe to } \\
\text { very severe }\end{array}$ & Japan & $\begin{array}{l}\text { Lysozyme } 90 \\
\text { mg } 3 \text { times dai- } \\
\text { ly }\end{array}$ & Placebo & $\begin{array}{l}\text { Exacerbation rate, time to first exacerba- } \\
\text { tion, lung function, CAT }\end{array}$ \\
\hline Grassi 1976 & 80 & 26 & 60.9 & & Italy & $\begin{array}{l}\text { NAC } 600 \mathrm{mg} \\
\text { daily }\end{array}$ & Placebo & $\begin{array}{l}\text { Exacerbations, clinical symptoms, sputum } \\
\text { characteristics, AEs }\end{array}$ \\
\hline Grassi 1994 & 135 & 13 & 61.8 & & Italy & $\begin{array}{l}\text { Carbocysteine } \\
1125 \mathrm{mg} \text { plus } \\
\text { sobrerol } 180 \mathrm{mg} \\
\text { once daily }\end{array}$ & $\begin{array}{l}\text { Placebo } \\
\text { or alter- } \\
\text { nating ac- } \\
\text { tive-placebo } \\
\text { for } 10 \text { days } \\
\text { each }\end{array}$ & $\begin{array}{l}\text { Exacerbations, symptoms, sputum char- } \\
\text { acteristics }\end{array}$ \\
\hline $\begin{array}{l}\text { Grillage } \\
1985\end{array}$ & 109 & 26 & $\begin{array}{l}\text { Not report- } \\
\text { ed }\end{array}$ & & Britain & $\begin{array}{l}\text { Carbocysteine } \\
750 \text { mg } 3 \text { times } \\
\text { daily }\end{array}$ & Placebo & Exacerbations, lung function, AEs \\
\hline $\begin{array}{l}\text { Hansen } \\
1994\end{array}$ & 153 & 22 & 51.4 & $\begin{array}{l}\text { Mild to } \\
\text { moderate }\end{array}$ & Denmark & $\begin{array}{l}\text { NAC } 600 \mathrm{mg} \\
\text { twice daily }\end{array}$ & Placebo & $\begin{array}{l}\text { Exacerbations, subjective symptom } \\
\text { scores, global well-being, lung function, } \\
\text { AEs }\end{array}$ \\
\hline
\end{tabular}




\begin{tabular}{|c|c|c|c|c|c|c|c|c|}
\hline $\begin{array}{l}\text { Jackson } \\
1984\end{array}$ & 155 & 13 & 63.0 & & $\begin{array}{l}\text { Great Briti- } \\
\text { ain }\end{array}$ & $\begin{array}{l}\text { NAC } 200 \mathrm{mg} 3 \\
\text { times daily }\end{array}$ & Placebo & $\begin{array}{l}\text { Exacerbations, subjective symptoms, clin- } \\
\text { ical signs, radiological appearance, global } \\
\text { well being, AEs }\end{array}$ \\
\hline $\begin{array}{l}\text { Johnson } \\
2016\end{array}$ & 51 & 8 & 70.0 & $\begin{array}{l}\text { Mild to mod- } \\
\text { erate }\end{array}$ & USA & $\begin{array}{l}\text { NAC } 1800 \mathrm{mg} \\
\text { twice daily }\end{array}$ & Placebo & $\begin{array}{l}\text { Change SGRQ, CBSAS, SF-36; post-bron- } \\
\text { chodilator lung function }\end{array}$ \\
\hline $\begin{array}{l}\text { Malerba } \\
2004\end{array}$ & 242 & 52 & 60.0 & Moderate & Italy & $\begin{array}{l}\text { Ambroxol } 75 \\
\text { mg twice daily }\end{array}$ & Placebo & $\begin{array}{l}\text { Exacerbation over first } 6 \text { months (winter } \\
\text { period) and at } 12 \text { months, cough intensi- } \\
\text { ty and frequency, difficult expectoration, } \\
\text { dyspnoea, days on antibiotics, number of } \\
\text { working days lost }\end{array}$ \\
\hline $\begin{array}{l}\text { McGavin } \\
1985\end{array}$ & 244 & 22 & 63.4 & $\begin{array}{l}\text { Severe } \\
\text { to very } \\
\text { severe }\end{array}$ & Great Britain & $\begin{array}{l}\text { NAC } 200 \mathrm{mg} 3 \\
\text { times daily }\end{array}$ & Placebo & $\begin{array}{l}\text { Exacerbation, days of antibiotics, days in } \\
\text { bed, } F E V_{1}, V C, A E s\end{array}$ \\
\hline Meister 1986 & 252 & 26 & 57,2 & & Germany & $\begin{array}{l}\text { NAC } 300 \mathrm{mg} \\
\text { twice daily }\end{array}$ & Placebo & $\begin{array}{l}\text { Exacerbation, days sick, concomitant } \\
\text { treatment, AEs }\end{array}$ \\
\hline Meister 1999 & 246 & 26 & 57.0 & $\begin{array}{l}\text { Mild to } \\
\text { moderate }\end{array}$ & Germany & $\begin{array}{l}\text { Myrtol } 300 \mathrm{mg} 3 \\
\text { times daily }\end{array}$ & Placebo & $\begin{array}{l}\text { Exacerbation, number of exacerbations } \\
\text { requiring antibiotics, well-being, AEs }\end{array}$ \\
\hline Moretti 2004 & 155 & 35 & 67.0 & $\begin{array}{l}\text { Moderate, } \\
\text { severe to } \\
\text { very severe }\end{array}$ & Italy & $\begin{array}{l}\text { Erdosteine } 300 \\
\text { mg twice daily }\end{array}$ & Placebo & $\begin{array}{l}\text { Exacerbation frequency, duration, hos- } \\
\text { pitalisation, lung function, 6MWT, SGRQ, } \\
\text { pharmacoeconomic analysis }\end{array}$ \\
\hline Nowak 1999 & 313 & 35 & 57.0 & & Europe & $\begin{array}{l}\text { NAC } 600 \mathrm{mg} \\
\text { daily }\end{array}$ & Placebo & $\begin{array}{l}\text { Exacerbation, severity of exacerbations, } \\
\text { time to first exacerbation, days sick, lung } \\
\text { function, patient symptoms, AEs }\end{array}$ \\
\hline Olivieri 1987 & 240 & 26 & $\begin{array}{l}\text { Not report- } \\
\text { ed }\end{array}$ & $\begin{array}{l}\text { Mild, mod- } \\
\text { erate } \\
\text { to severe }\end{array}$ & Italy & $\begin{array}{l}\text { Ambroxol re- } \\
\text { tard } 75 \text { mg daily }\end{array}$ & Placebo & $\begin{array}{l}\text { Exacerbation, course of antibiotics, days } \\
\text { sick, } \mathrm{FEV}_{1}, \mathrm{VC} \text {, symptoms, auscultatory } \\
\text { findings, physicians' and patients' global } \\
\text { assessments, laboratory data, AEs }\end{array}$ \\
\hline Parr 1987 & 526 & 26 & 63.0 & & Great Britain & $\begin{array}{l}\text { NAC } 200 \mathrm{mg} 3 \\
\text { times daily }\end{array}$ & Placebo & Exacerbation, days off work, AEs \\
\hline Pela 1999 & 169 & 26 & 66.0 & $\begin{array}{l}\text { Moderate, } \\
\text { severe to } \\
\text { very severe }\end{array}$ & Italy & $\begin{array}{l}\text { NAC } 600 \mathrm{mg} \\
\text { daily }\end{array}$ & Placebo & $\begin{array}{l}\text { Exacerbation, exacerbation severity, days } \\
\text { sick, patient preference, lung function }\end{array}$ \\
\hline
\end{tabular}




\begin{tabular}{|c|c|c|c|c|c|c|c|c|}
\hline Petty 1990 & 367 & 8 & 65.0 & $\begin{array}{l}\text { Moderate, } \\
\text { severe to } \\
\text { very severe }\end{array}$ & USA & $\begin{array}{l}\text { lodinated glyc- } \\
\text { erol } 30 \mathrm{mg} 4 \\
\text { times daily }\end{array}$ & Placebo & $\begin{array}{l}\text { Investigator assessment of symptoms, pa- } \\
\text { tient evaluation of symptoms and global } \\
\text { assessment, frequency of bronchodilator } \\
\text { use, number and duration of acute exac- } \\
\text { erbations, frequency of concomitant med- } \\
\text { ications, AEs }\end{array}$ \\
\hline $\begin{array}{l}\text { Rasmussen } \\
1988\end{array}$ & 116 & 26 & 58.9 & & Sweden & $\begin{array}{l}\text { NAC } 300 \mathrm{mg} \\
\text { twice daily }\end{array}$ & Placebo & $\begin{array}{l}\text { Exacerbation, days sick evaluated by days } \\
\text { on sick list and by patient diaries, AEs }\end{array}$ \\
\hline Roy 2014 & 80 & 26 & 61.0 & $\begin{array}{l}\text { Mild to Mod- } \\
\text { erate }\end{array}$ & India & $\begin{array}{l}\text { NAC } 600 \mathrm{mg} \\
\text { twice daily }\end{array}$ & Placebo & $\begin{array}{l}\text { Symptoms (cough, dyspnoea, sputum), } \\
\text { lung function, haemoglobin levels, AEs }\end{array}$ \\
\hline $\begin{array}{l}\text { Schermer } \\
2009\end{array}$ & 192 & 156 & 59.0 & $\begin{array}{l}\text { Mild, mod- } \\
\text { erate, } \\
\text { severe to } \\
\text { very severe }\end{array}$ & Netherlands & $\begin{array}{l}\text { NAC } 600 \mathrm{mg} \\
\text { daily }\end{array}$ & Placebo & Rate of exacerbations, CRQ \\
\hline Tse 2013 & 133 & 52 & 71.0 & $\begin{array}{l}\text { Mild, mod- } \\
\text { erate } \\
\text { to severe }\end{array}$ & China & $\begin{array}{l}\text { NAC } 600 \mathrm{mg} \\
\text { twice daily }\end{array}$ & Placebo & $\begin{array}{l}\text { Small airways parameters } \mathrm{FEF}_{25-75 \%} \text {, FOT, } \\
\text { IC, spirometry, exacerbation rate, dysp- } \\
\text { noea, SGRQ, } 6 \text { MWD }\end{array}$ \\
\hline Worth 2009 & 220 & 26 & 62.3 & $\begin{array}{l}\text { Moderate } \\
\text { to severe }\end{array}$ & Germany & $\begin{array}{l}\text { Cineole } 200 \mathrm{mg} \\
3 \text { times daily }\end{array}$ & Placebo & $\begin{array}{l}\text { Exacerbations: number, severity, and du- } \\
\text { ration, lung function, dyspnoea, SGRQ, } \\
\text { AEs }\end{array}$ \\
\hline Xu 2014 & 84 & 26 & $\begin{array}{l}\text { Not report- } \\
\text { ed }\end{array}$ & $\begin{array}{l}\text { Moderate } \\
\text { to severe }\end{array}$ & China & $\begin{array}{l}\text { NAC } 600 \mathrm{mg} \\
\text { twice daily }\end{array}$ & $\begin{array}{l}\text { Salme- } \\
\text { terol/flutica- } \\
\text { sone propi- } \\
\text { onate }\end{array}$ & $\begin{array}{l}\mathrm{FEV}_{1} \% / \mathrm{FVC}, \mathrm{FEV}_{1} \% \text { predicted, } \mathrm{PEF} \% \text { daily } \\
\text { variation change, } \mathrm{PaO}_{2}, \mathrm{PaCO}_{2}\end{array}$ \\
\hline Zheng 2008 & 709 & 52 & 65.0 & $\begin{array}{l}\text { Moderate, } \\
\text { severe to } \\
\text { very severe }\end{array}$ & China & $\begin{array}{l}\text { Carbocysteine } \\
500 \text { mg } 3 \text { times } \\
\text { daily }\end{array}$ & Placebo & $\begin{array}{l}\text { Exacerbation rate, covariance-adjusted } \\
\text { exacerbation rate, QoL, lung function, ar- } \\
\text { terial oxygen saturation }\end{array}$ \\
\hline Zheng 2014 & 1006 & 52 & 66.0 & $\begin{array}{l}\text { Moderate } \\
\text { to severe }\end{array}$ & China & $\begin{array}{l}\text { NAC } 600 \mathrm{mg} 3 \\
\text { times daily }\end{array}$ & Placebo & $\begin{array}{l}\text { Exacerbation rate, exacerbation duration, } \\
\text { time to first exacerbation, time to recur- } \\
\text { rent exacerbation, number of participants } \\
\text { requiring systemic corticosteroids or an- } \\
\text { tibiotics or SABA, SGRQ (Chinese version), } \\
\text { lung function, AEs (including hospitalisa- } \\
\text { tion or death) }\end{array}$ \\
\hline
\end{tabular}


6MWD: six-minute walk distance; AEs: adverse events; CAT: COPD assessment test; CBSAS: Chronic Bronchitis Symptoms Assessment Scale; CRQ: chronic respiratory questionnaire; $\mathrm{FEF}_{25-75 \%}$ : forced expiratory flow at $25 \%-75 \%$ of the pulmonary volume; $\mathrm{FEV}_{1}$ : forced expiratory volume in one second; FOT: forced oscillatory technique; FVC: forced vital capacity; IC: inspiratory capacity; $\mathrm{NAC}$ : N-acetylcysteine; $\mathrm{NIC}$ : $\mathrm{N}$-isobutyrylcysteine; $\mathrm{PaCO}_{2}$ : partial pressure of carbon dioxide; PaO ${ }_{2}$ : partial pressure of oxygen; $\mathrm{PEF}$ : peak expiratory flow; QoL: quality of life; SABA: short-acting beta-agonist; SCMC-Lys: carbocysteine lysine salt monohydrate; SF-36:Short Form-36 Health Survey; SGRQ: St. George's respiratory questionnaire; VC: vital capacity. 


\section{APPENDICES}

\section{Appendix 1. Search history}

\begin{tabular}{ll}
\hline Years & Search result detail \\
\hline All years to January 1998 & $\begin{array}{l}\text { We screened approximately } 400 \text { abstracts of papers identified by computer searches. After exclud- } \\
\text { ing studies that were clearly ineligible based on the abstract, we obtained the full text for } 72 \text { pa- } \\
\text { pers. } 21 \text { studies involved double-blind, placebo-controlled treatment with an oral mucolytic for at } \\
\text { least } 8 \text { weeks. } 3 \text { were excluded because they did not provide information on the primary outcome } \\
\text { (Edwards 1976; Maesen 1980; Rubin 1996). Three studies were excluded because they did not re- } \\
\text { port the standard deviation for outcome measures of interest, and we could not obtain this infor- } \\
\text { mation despite writing to study authors (Christensen 1971; Grillage 1985; Jackson 1984). 15 studies } \\
\text { were included in the review }\end{array}$ \\
\hline
\end{tabular}

January 1998 to 1999

For the 1999 update, one further study was identified that had been detected on the original search (Cegla 1988), but for which the full text had not been obtained in 1997. Grillage 1985 and Jackson 1984 were not included in the original review but were included in the update, as they had data on participants with no exacerbations - an outcome measure that was added for the update. For this update, and until further clarification is obtained from study authors, we have assumed that error measurement reported in Olivieri 1987 is an SE rather than an SD (see Lung Function)

January 1999 to 2002

In 2002, the search was widened to (chronic bronchitis or emphysema or chronic obstructive pulmonary disease or COPD) AND (mucolytics or mucoactive or N-acetylcysteine or bromhexine or Scarboxymethylcysteine or ambroxol or sobrerol or iodinated glycerol or $\mathrm{N}$ isobutyrylcysteine or myrtol or NAC or methylcysteine or carbocysteine or erdosteine or strepronin or gelsolin or MESNA). No further eligible studies were identified by this search

$\begin{array}{ll}\text { January } 2002 \text { to January } 2003 & \begin{array}{l}\text { In 2003, a repeat search with the same terms yielded } 44 \text { titles, of which } 18 \text { abstracts were screened } \\ \text { for eligibility and } 5 \text { full texts were retrieved; none were eligible }\end{array}\end{array}$

$\begin{array}{ll}\text { January 2003-Sept } 2005 & \begin{array}{l}\text { An update search conducted in } 2005 \text { yielded another } 264 \text { titles, of which } 9 \text { full texts were retrieved, } \\ \text { yielding a further } 3 \text { studies for inclusion (Decramer 2005; Malerba 2004; Moretti 2004). }\end{array}\end{array}$

2005-2007 A search in 2005 yielded another 16 titles, none of which were eligible; in 2006, a further 2 titles were found with the COOPT study eligible

2008 Searches in 2008 yielded 20 titles, with 2 more original studies for inclusion (Bachh 2007; Zheng

May 2011

In 2011, 64 abstracts and papers were identified by the searches. Several reports were related to the PEACE study (Zheng 2008), and to the EQUALIFE study already included in this review (Moretti 2004). Of 7 full texts reviewed, 4 proved eligible: 2 related to the same study of cineole in COPD (Worth and Worth); another to a further study of cineole (Wilhelmi); one was a further post hoc analysis of EQUALIFE (Ballabio 2008a). One study (Lukas) of NAC in CB was excluded, as no data were available on outcomes in this review

Furthermore, we were informed about studies of neltenexine, which is a mucolytic, and we considered the full texts of these, which were ineligible. Thus data from 2 new studies were added for the 2012 update

(mucolytic* or "mucociliary clearance" or mucoactive or N-acetylcysteine or bromhexine or S-carboxymethylcysteine or ambroxol or sobrerol or "iodinated glycerol" or $\mathrm{N}$ isobutyrylcysteine or myrtol or NAC or methylcysteine or carbocysteine or erdosteine or strepronin* or gelsolin or MESNA)

In 2011, the above search was run from 2008 to the present date, but with the addition of the term "cineole". We were notified about eligible studies of "neltenexine". This term should be included in the next search 
(Continued)

July 2012 In 2012, 8 abstracts and papers were identified. An abstract was added to "Studies awaiting classification" (Moretti 2011a)

July 2014 A search in July 2014 using the terms below yielded 29 new references (The full search strategy used in this update is provided in Appendix 3)

Full texts of studies that were possibly eligible were retrieved. The Moretti trial mentioned above was ineligible. Several studies had duplicate reports. A search was made of the bibliographies of eligible studies, as well as of online clinical trials. A duplicate paper on a trial already identified was found during a search for study author details. From these searches, 4 new eligible trials were identified for inclusion in this review (De Backer 2013; Roy 2014; Tse 2013; Zheng 2014). We wrote to Dr De Backer to request additional information on the secondary outcomes of SGRQ and spirometry alluded to in their paper, with no response. Dr Zheng provided further information on several outcomes (Zheng 2014)

July 2017

A database search yielded 54 references, and searches of clinical trial registries identified a further 13 records. We excluded 50 on the basis of title and abstract and reviewed 17 full texts for possible inclusion. We excluded a further six records ( 5 unique studies) at this stage and identified 1 ongoing study that meets the inclusion criteria for this review. The remaining 10 records were eligible for inclusion. Six records, linked to 4 new unique studies, were added to the review (Dal Negro 2017; Fukuchi 2016; Johnson 2016; Xu 2014). A further 4 records identified were additional references to studies already included in the review

Appendix 2. Sources and search methods for the Cochrane Airways Group Specialised Register (CAGR) Electronic searches: core databases

\begin{tabular}{lll}
\hline Database & Dates searched & Frequency of search \\
\hline CENTRAL (via the Cochrane Register of Studies (CRS)) & From inception & Monthly \\
\hline MEDLINE (Ovid) & 1946 onwards & Weekly \\
\hline EMBASE (Ovid) & 1974 onwards & Weekly \\
\hline PSycINFO (Ovid) & 1967 onwards & Monthly \\
\hline CINAHL (EBSCO) & 1937 onwards & Monthly \\
\hline AMED (EBSCO) & From inception & Monthly \\
\hline
\end{tabular}

Handsearches: core respiratory conference abstracts

\begin{tabular}{ll}
\hline Conference & Years searched \\
\hline American Academy of Allergy, Asthma and Immunology (AAAA) & 2001 onwards \\
\hline American Thoracic Society (ATS) & 2001 onwards \\
\hline
\end{tabular}


(Continued)

Asia Pacific Society of Respirology (APSR)

2004 onwards

\begin{tabular}{lc}
\hline British Thoracic Society Winter Meeting (BTS) & 2000 onwards \\
\hline Chest Meeting & 2003 onwards \\
\hline European Respiratory Society (ERS) & $1992,1994,2000$ onwards \\
\hline International Primary Care Respiratory Group Congress (IPCRG) & 2002 onwards \\
\hline Thoracic Society of Australia and New Zealand (TSANZ) & 1999 onwards \\
\hline
\end{tabular}

\section{MEDLINE search strategy used to identify trials for the Cochrane Airways Trials Register}

\section{COPD search}

1. Lung Diseases, Obstructive/

2. exp Pulmonary Disease, Chronic Obstructive/

3. emphysema\$.mp.

4. (chronic\$ adj3 bronchiti\$).mp.

5. (obstruct\$ adj3 (pulmonary or lung\$ or airway\$ or airflow\$ or bronch\$ or respirat\$)).mp.

6. COPD.mp.

7. COAD.mp.

8. COBD.mp.

9. AECB.mp.

10. or/1-9

\section{Filter to identify RCTs}

1. exp "clinical trial [publication type]"/

2. (randomised or randomised).ab,ti.

3. placebo.ab,ti.

4. dt.fs.

5. randomly.ab,ti.

6. trial.ab,ti.

7. groups.ab,ti.

8. or/1-7

9. Animals/

10. Humans/

11.9 not (9 and 10)

12. 8 not 11 
The MEDLINE strategy and RCT filter are adapted to identify trials in other electronic databases

\section{Appendix 3. Search strategy to identify relevant trials from the Cochrane Airways Trials Register Search platform: Cochrane Register of Studies (CRS)}

\#1 MeSH DESCRIPTOR Pulmonary Disease, Chronic Obstructive Explode All

\#2 MeSH DESCRIPTOR Bronchitis, Chronic

\#3 (obstruct ${ }^{\star}$ ) near3 (pulmonary or lung* or airway ${ }^{\star}$ or airflow $^{\star}$ or bronch ${ }^{\star}$ or respirat ${ }^{\star}$ )

\#4 COPD:MISC1

\#5 (COPD OR COAD OR COBD):TI,AB,KW

\#6 \#1 OR \#2 OR \#3 OR \#4 OR \#5

\#7 MeSH DESCRIPTOR Expectorants

\#8 mucolytic ${ }^{\star}$

\#9 mucociliary $^{\star}$ NEXT clearance*

\#10 mucoactive

$\# 11$ *acetylcysteine

\#12 bromhexine

$\# 13$ * carboxymethylcysteine

\#14 ambroxol

\#15 sobrerol

\#16 "iodinated glycerol"

\#17 isobutyrylcysteine

\#18 myrtol

\#19 NAC:ti,ab

\#20 methylcysteine

\#21 carbocysteine

\#22 erdosteine

\#23 strepronin *

\#24 gelsolin

\#25 mesna*

\#26 cineole

\#27 neltenexine

\#28 eucalyptus

$\# 29 \# 7$ or \#8 or \#9 or \#10 or \#11 or \#12 or \#13 or \#14 or \#15 or \#16 or \#17 or \#18 or \#19 or \#20 or \#21 or \#22 or \#23 or \#24 or \#25 or \#26 or \#27 or \#28

$\# 30$ \# and \#29

[Note: in search line \#4, MISC1 denotes the field in which the reference has been coded for condition, in this case, COPD] 


\section{FEEDBACK}

\section{Incorrect dose reported in Zheng 2014 study, 13 February 2020}

\section{Summary}

In reading the 2019 update to "Mucolytic agents versus placebo for chronic bronchitis or chronic obstructive pulmonary disease," I noticed that the $\mathrm{N}$-acetylcysteine (NAC) dose in Zheng 2014 was reported as $1800 \mathrm{mg}$. In reading the published PANTHEON study, the intervention of NAC was $600 \mathrm{mg}$ twice daily which would put it in the $1200 \mathrm{mg}$ per day subgroup. Could you please comment on the dose? Thank you.

Reference: Zheng JP, Wen FQ, Bai CX, et al.PANTHEON study group. Twice daily N-acetylcysteine 600 mg for exacerbations of chronic obstructive pulmonary disease (PANTHEON): a randomised, doubleblind placebo-controlled trial. Lancet Respir Med. 2014 Mar;2(3):187-94. doi: 10.1016/S2213-2600(13)70286-8

\section{Reply}

We thank the reader Kathy Grams very much for her interest in our review and for taking the time to give feedback, which in this case corrects an error.

We had indeed recorded the N-acetylcysteine (NAC) dose in the PANTHEON study by Zheng et al. 2014 as $1800 \mathrm{mg}$. It is in fact $1200 \mathrm{mg}$, being $600 \mathrm{mg}$ twice daily. As a result of this we have made the following changes:

1. Corrected the dose in the Characteristics of included studies table

2. Corrected text describing included studies

3. In Analysis 1.4 moved Zheng from the $1800 \mathrm{mg}$ subgroup to the $1200 \mathrm{mg}$ subgroup.

4. Minor change to text describing this result.

While there are no changes to the overall findings of the review, we appreciate getting the information in the review as correct as possible.

\section{Contributors}

Feedback contributor: Kathy Grams, PharmD, BCGP

Author contributor: Phillippa Poole on behalf of the author team.

WHAT'S NEW

\begin{tabular}{lll}
\hline Date & Event & Description \\
\hline 9 March 2020 & Feedback has been incorporated & $\begin{array}{l}\text { Authors made changes to the reporting of one of the studies in } \\
\text { the review. See Feedback 1. There were no changes to the overall } \\
\text { findings of the review. }\end{array}$ \\
\hline 9 March 2020 & Amended & Feedback added. \\
\hline
\end{tabular}

\section{H I S T O R Y}

Protocol first published: Issue 2, 1996

Review first published: Issue 4, 1998

\begin{tabular}{|c|c|c|}
\hline Date & Event & Description \\
\hline 23 April 2019 & New search has been performed & - New literature search performed \\
\hline 23 April 2019 & $\begin{array}{l}\text { New citation required and conclusions } \\
\text { have changed }\end{array}$ & $\begin{array}{l}\text { - Change in review author team } \\
\text { - Inclusion of } 4 \text { new studies (Dal Negro 2017; Fukuchi 2016; John- } \\
\text { son 2016; Xu 2014) } \\
\text { - Removal of meta-analysis of outcome exacerbations per par- } \\
\text { ticipant per month for methodological reasons }\end{array}$ \\
\hline
\end{tabular}




\begin{tabular}{|c|c|c|}
\hline Date & Event & Description \\
\hline & & $\begin{array}{l}\text { - Lung function outcomes separated into } \mathrm{FEV}_{1}, \mathrm{FEV}_{1} \% \text { predict- } \\
\text { ed, PEFR, and FVC } \\
\text { - ICS allowed vs ICS not allowed subgrouping amended } \\
\text { - Conclusions for primary outcomes unchanged } \\
\text { - Conclusions for secondary outcomes strengthened: } \\
\text { ○ Increased certainty that mucolytics do not have an impor- } \\
\text { tant impact on quality of life or lung function } \\
\text { ○ Increased certainty that mucolytics are well tolerated }\end{array}$ \\
\hline 3 July 2014 & $\begin{array}{l}\text { New citation required but conclusions } \\
\text { have not changed }\end{array}$ & $\begin{array}{l}\text { - Change in review authors } \\
\text { - Inclusion of } 4 \text { new studies, all of NAC vs placebo (De Backer } \\
\text { 2013; Roy 2014; Tse 2013; Zheng 2014) } \\
\text { - Addition of an analysis of studies lasting } 12 \text { months or longer } \\
\text { - Addition to subgroup analysis of NAC at higher doses ( } 1200 \mathrm{mg} \text { / } \\
\text { d and } 1800 \mathrm{mg} / \mathrm{d} \text { ) } \\
\text { - For primary outcomes, minimal changes - all heading towards } \\
\text { null effect, despite increased doses of NAC } \\
\text { o Slightly reduced likelihood of no exacerbations during study } \\
\text { - period } \\
\text { - Addightly reduced effect size for exacerbation rate } \\
\text { - } \text { - Addition of 'Summary of findings' table } \\
\text { - Updated versions of 'Risk of bias' tables }\end{array}$ \\
\hline
\end{tabular}

\begin{tabular}{|c|c|c|}
\hline 3 July 2014 & New search has been performed & New literature search \\
\hline 5 July 2012 & New search has been performed & $\begin{array}{l}2 \text { new studies (Worth } 2009 \text { (cineole) and Schermer } 2009 \text { (N- } \\
\text { acetylcysteine (NAC)) included. Data from these studies and from } \\
\text { Decramer } 2005 \text { included in a new analysis for SGRQ (St George } \\
\text { Respiratory Questionnaire). 'Summary of findings' table added. } \\
\text { Third review author (CC) added to the review. Potentially eligible } \\
\text { abstract added to Studies awaiting classification }\end{array}$ \\
\hline
\end{tabular}

5 July $2012 \quad$ New citation required and conclusions

Conclusions similar, although smaller beneficial effects of muhave changed colytics on exacerbations noted in more recent trials than in earlier trials

\begin{tabular}{ll}
\hline 1 November 2008 & $\begin{array}{l}\text { New citation required but conclusions } \\
\text { have not changed }\end{array}$ \\
\hline 15 September 2008 & New search has been performed \\
\hline 8 August 2008 & Amended \\
\hline 10 March 2006 & $\begin{array}{l}\text { New citation required and conclusions } \\
\text { have changed }\end{array}$
\end{tabular}

Review updated to take account of 2 new studies

Search rerun

Converted to new review format

2005: search repeated, full update performed. Three new studies, including 3-year BRONCHUS study of $600 \mathrm{mg} \mathrm{NAC}$, included. Smaller effect size of all mucolytics combined than previously. Reasons for this discussed

In the BRONCHUS study, significant effect of NAC on exacerbations noted among participants not using inhaled corticosteroids. New comparison added to address this

Other new comparisons added: hospitalisations, deaths 


\begin{tabular}{lll}
\hline Date Event Description & Denthe
\end{tabular}

Otherwise, findings much the same as previously

1 August $2002 \quad$ New search has been performed

2002: no new studies found despite use of wider search strategy. Discussion expanded to include information on other recent meta-analyses of NAC and a comparison of the effects of mucolytics and fluticasone on exacerbations. Jadad scores for studies now included

Data and conclusions same as in 1999

31 August $1999 \quad$ New search has been performed

\begin{abstract}
1999: 2 studies in patients with COPD now included in the review, hence the title change. Data on 2 other agents - myrtol and the thiol donor $\mathrm{N}$-isobutyrylcysteine - also included. Eight additional studies and several new analyses included
\end{abstract}

\begin{abstract}
Correction made to reviewers' conclusions on the effects of mucolytics on the secondary endpoint of lung function. Our extracted data checked against original data and confirmed as correct. Small standard deviations in the Olivieri study noted; possibility that study authors reported standard errors. P values quoted in study analysis compatible with this conclusion. Until clarification, this trial removed from analysis. No significant change in lung function noted in data analysis (previously interpreted as favouring placebo). Changes made to relevant parts of Abstract, Results (Lung Function), and Discussion sections
\end{abstract}

\begin{abstract}
No change to overall conclusions of this review with respect to primary endpoint of exacerbation frequency and days of disability ('sick days'). High level of heterogeneity in the size of this effect between trials unclear; possibility that length of study is the cause of this should be examined in a future version of this review
\end{abstract}

For adverse effects, Parr and Rasmussen data taken out of metaanalysis and reported instead in text because event rates in these studies exceeded numbers in treatment groups. RevMan unable to manage dichotomous data when event rate exceeds 1. Possibility that adverse effects may be less frequent in the mucolytic-treated group as suggested by meta-analysis. In large study by Parr $(n=526)$, mean of 4.9 adverse effects reported per participant in the mucolytic group vs 4.5 adverse effects per participant in the placebo group. Therefore, no changes made to our original conclusion and no differences between treatments in terms of adverse effects

\section{CONTRIBUTIONS OF AUTHORS}

Dr Phillippa Poole has had the primary overall responsibility for this review throughout its iterations. Until his death in 2010 , Dr Black contributed to all aspects of the review, including approval of the final version of the substantive updates in 1999, 2002, 2005, 2006, and 2008. Dr Chris Cates has provided support for the review from inception. He has assisted with analysis, interpretation, data-checking, and write-up of the 2012 and 2014/15 updates. Dr Jimmy Chong assisted with determining study eligibility, checking data, and writing up the 2012 and 2014/15 updates. Dr Rebecca Fortescue and Kavin Sathananthan joined the team for the 2019 update and contributed to data extraction and entry and write-up. Dr Jimmy Chong and Dr Chris Cates stepped down from the author line for this most recent update.

\section{Contributions of editorial team}

Chris Cates (Co-ordinating Editor) checked the data entry before the full write-up of the review.

Sally Spencer (Editor) edited the review; advised on methodology, interpretation, and content; and approved changes after peer review. 
Emma Dennett (Managing Editor) co-ordinated the editorial process; advised on interpretation and content; and edited the review. Emma Jackson (Assistant Managing Editor) conducted peer review; and edited the plain language summary and reference sections of the protocol and the review.

Elizabeth Stovold (Information Specialist) designed the search strategy; ran the searches; and edited the search methods section. Sarah Hodgkinson (Associate Editor, Cochrane Circulation and Breathing Network) screened the review and provided feedback.

\section{DECLARATIONS OF INTEREST}

PP: none known. I am an editor with Cochrane Airways.

KS: none known.

RF: none known. I am Joint Co-ordinating Editor of Cochrane Airways, employed by an NIHR grant, and a qualified general practitioner.

\section{SOURCES OF SUPPORT}

\section{Internal sources}

- No support received, Other.

- The authors declare that no such funding was received for this systematic review, Other.

\section{External sources}

- The authors declare that no such funding was received for this systematic review, Other.

\section{DIFFERENCES BETWEEN PROTOCOLANDREVIEW}

We searched trial registries for the update.

This review has used a modified version of the full 'Risk of bias' tool described in Chapter 8 of the Cochrane Handbook for Systematic Reviews of Interventions. The protocol and initial review versions used Jadad scores to assess trial quality. We have updated the 'Risk of bias' assessment to use the latest version of the Cochrane 'Risk of bias' tool.

Additional outcomes were added for updates from 2006 to 2012.

- Hospitalisation and mortality (added as outcomes for the 2006 and 2008 updates).

- Quality of life (added for the 2008 update, with a meta-analysis of SGRQ scores included for the 2012 update).

Double-blinding was not an inclusion criterion.

For the 2019 update, we removed the exacerbations per patient per month analyses, as these are not considered to be as statistically robust as the dichotomous exacerbation outcome, largely due to likely skew in this measure. In addition, we reviewed the Bontognali 1991 data for this outcome and removed them due to discrepancies in Table II of the publication, leading us to believe there are mistakes in the reported exacerbation data. Furthermore, following editorial advice, we conducted a sensitivity analysis while removing those studies judged to be at high risk of attrition bias.

\section{INDEX TERMS}

\section{Medical Subject Headings (MeSH)}

Bronchitis, Chronic [ ${ }^{\star}$ drug therapy] [prevention \& control]; Disease Progression; Expectorants [ ${ }^{*}$ therapeutic use]; Pulmonary Disease, Chronic Obstructive [ ${ }^{\star}$ drug therapy] [prevention \& control]; Quality of Life; Randomized Controlled Trials as Topic; Treatment Outcome

\section{MeSH check words}

Humans 